CENTRO UNIVERSITÁRIO FEI

ANDREY ARAUJO MASIERO

MÉTODO CENTRADO NO USUÁRIO PARA CONSTRUÇÃO DE ROBÔS AUTÔNOMOS VISANDO A INTERAÇÃO COM HUMANOS

São Bernardo do Campo 

ANDREY ARAUJO MASIERO

\section{MÉTODO CENTRADO NO USUÁRIO PARA CONSTRUÇÃO DE ROBÔS AUTÔNOMOS VISANDO A INTERAÇÃO COM HUMANOS}

Tese de Doutorado apresentada ao Centro Universitário FEI para obtenção do título de Doutor em Engenharia Elétrica, orientado pelo Prof. Dr. Plinio Thomaz Aquino Junior e coorientado pelo Prof. Dr. Flavio Tonidandel.

São Bernardo do Campo 


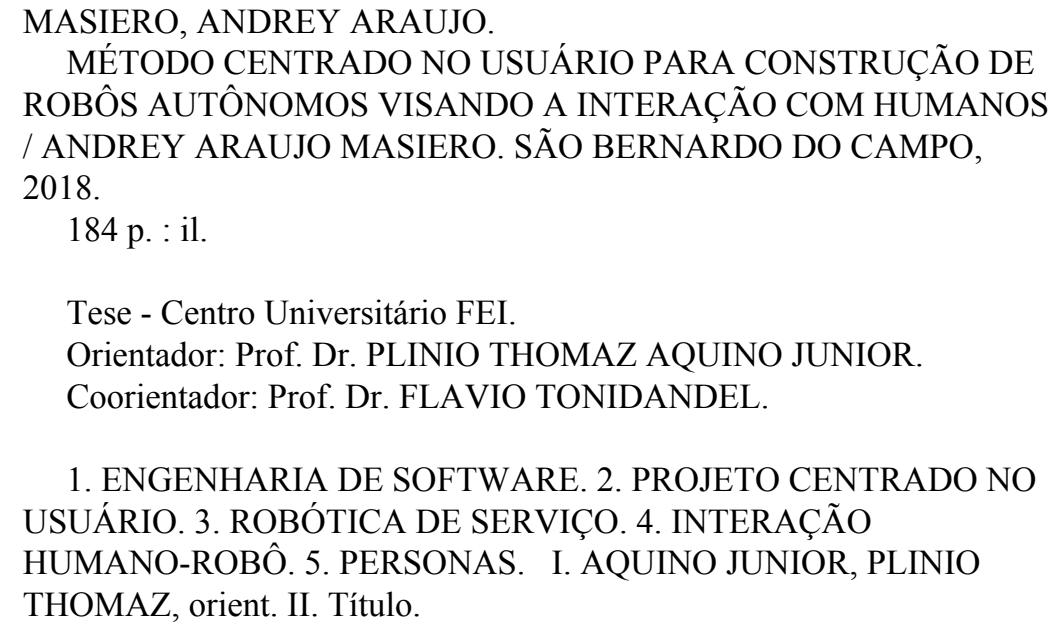

1. ENGENHARIA DE SOFTWARE. 2. PROJETO CENTRADO NO USUÁRIO. 3. ROBÓTICA DE SERVIÇO. 4. INTERAÇÃO HUMANO-ROBÔ. 5. PERSONAS. I. AQUINO JUNIOR, PLINIO THOMAZ, orient. II. Título.

Elaborada pelo sistema de geração automática de ficha catalográfica da FEI com os dados fornecidos pelo(a) autor(a). 
Título do Trabalho: Método centrado no usuário para construção de robôs autônomos visando a interação com humanos.

Área de Concentração: Inteligência Artificial Aplicada à Automação e Robótica

Orientador: Prof. Dr. Plinio Thomaz Aquino Junior

Data da realização da defesa: 06/02/2018

São Bernardo do Campo, 06 / 02 / 2018.

\begin{tabular}{|c|c|}
\hline \multicolumn{2}{|c|}{ MEMBROS DA BANCA EXAMINADORA } \\
\hline Prof. Dr. Plinio Thomaz Aquino Junior & Ass.: \\
\hline Prof. Dr. Reinaldo Augusto da Costa Bianchi & Ass.: \\
\hline Prof. a Dr. ${ }^{a}$ Esther Luna Colombini & Ass.: \\
\hline Prof. Dr. João Alberto Fabro & Ass.: \\
\hline Prof. a Dr. a Lucia Vilela Leite Filgueiras & Ass.: \\
\hline \multicolumn{2}{|c|}{ A Banca Examinadora acima-assinada atribuiu ao aluno o seguinte: } \\
\hline APROVADO \ & ROVADO $\square$ \\
\hline
\end{tabular}

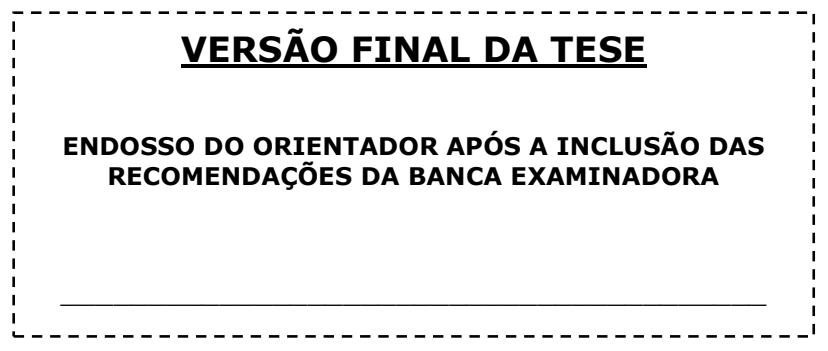

Aprovação do Coordenador do Programa de Pós-graduação 

A Deus e a minha família que são o alicerce de minha vida. 



\section{AGRADECIMENTOS}

Em primeiro lugar gostaria de agradecer a Deus, que sempre me trouxe sabedoria e luz, mesmo nos momentos difíceis dessa jornada e de tantas outras.

À minha mãe Kathia, que desde o primeiro momento me apoiou e incentivou, mesmo quando tudo parecia impossível e eu não conseguia ver a luz no fim do túnel.

À minha irmã Andressa, que me suportou quando fiquei exaltado de felicidade ou tristeza perante as dificuldades.

Aos meus avós, Hélio e Rachel, que mesmo não presentes em carne, continuam iluminando minha vida e me guiam pelos caminhos que percorro deixando a sensação de sempre estar seguro.

Ao professor e orientador Plinio Thomaz Aquino Junior, que me auxilia a direcionar os caminhos ao longo da jornada acadêmica e pessoal, com seus sábios conselhos e cumplicidade, fortalecendo a parceira a cada momento nesses últimos anos.

Ao professor e coorientador Flavio Tonidandel, que ajudou a tornar esse trabalho possível, com seus conselhos e ensinamentos, além de sempre puxar a minha orelha quando algo estava estranho ou elogiar sempre que eu conseguia um bom resultado. Tudo isso faz com que nossa parceria seja majestosa, desde a época do mestrado.

Aos professores da FEI, que compartilharam ao longo desse período seus conhecimentos e amizade, ajudando na evolução desse trabalho e também a minha como pessoa.

Aos meus amigos, que sem esse laço seria impossível avançar mais um passo neste caminho cheio de curvas. Os momentos de descontração, de discussão, almoços e principalmente cafés foram e são de extrema importância para nos ajudar a andar no caminho chamado vida.

E por fim a todos que de alguma maneira contribuíram para mais essa conquista. 

"O olho vê, a lembrança revê, e a imaginação transvê. É preciso transver o mundo"

Manoel de Barros 



\section{RESUMO}

O cenário da robótica no mundo tem mudado com o passar dos últimos anos. Antes o ambiente de robô tinha seu foco apenas na indústria, e agora existe uma ênfase maior nos chamados robôs de serviços. A International Federation of Robotics (IFR) define robôs de serviços como qualquer robô que esteja fora de um cenário industrial. Eles encontram-se em áreas como agricultura, hospitais, hotéis, escritórios e residências. Dessa maneira, a necessidade de interação entre os robôs e os seres humanos torna-se inevitável. Assim, pesquisadores têm se dedicado a criação de projetos cada vez mais preocupados com a interação social entre humanos e robô. Técnicas de experiência do usuário, controle e inteligência artificial são empregadas nos trabalhos de interação humano-robô com o intuito garantir mais qualidade no contato entre ambos. Entretanto, os projetos de interação humano-robô discutidos na literatura têm foco em pequenas partes da interação, como controle de toque, naturalidade dos gestos e movimentos, desvios de obstáculos, reconhecimento de pessoas, entre outros. Essas partes se preocupam mais com o comportamento e habilidades do robô do que com o usuário. Há a falta de um método sistêmico que possibilite a documentação, evolução e manutenção de robôs autônomos de serviço. Além do método sistêmico, um método que seja centrado no usuário é importante dada a atividade conjunta ao ser humano. Essa tese apresenta um método centrado no usuário para a construção de um robô autônomo, que tem como foco a interação entre humanos e robô. O método proposto é aplicado em um estudo de caso baseado em um cenário doméstico, onde o robô interage através de voz e possui navegação totalmente autônoma. A técnica de Personas é utilizada para identificar o perfil do usuário e um classificador Bayesiano é apresentado como meio de ilustrar a proposta de uma parte da etapa de tomada de decisão do robô. Os resultados mostram a importância de método, principalmente pela evolução do projeto e manutenções que foram necessárias durante os testes na aplicação do estudo de caso.

Palavras-chave: Engenharia de Software, Projeto centrado no Usuário, Robótica de Serviço, Interação Humano-Robô, Personas 



\begin{abstract}
The robotics scene in the world has changed over the last few years. Before the robot environment had its focus only on the industry. Now there is a greater emphasis on so-called service robots. The International Federation of Robotics (IFR) defines service robots as any robot out of an industrial setting. They are in areas such as agriculture, hospitals, hotels, offices and residences. In this way, the need for interaction between robots and humans becomes inevitable. Thus, researchers have dedicated to creating projects concerned with social humanrobot interaction. The human-robot interaction works to guarantee more quality in interaction. It uses techniques of user experience, control and artificial intelligence. Human-robot interaction discussed in the literature focus on small parts of the project. Some examples are: touch control, naturalness of gestures and movements, deviations of obstacles, recognition of people, among others. These parties are more concerned with the behavior and skills of the robot than with the user. There is a lack of a systemic method that enables the documentation, evolution and maintenance of autonomous service robots. Besides to the systemic method, one that is user centered is important given the joint activity to the human being. This thesis presents a user-centered method for constructing an autonomous robot. It focus on human-robot interaction. The proposed method is applied in a case study based on a domestic scenario, where the robot interacts through voice and has autonomous navigation. The Personas technique is used to identify the user profile. A Bayesian classifier is presented as a way to illustrate the proposal of a part of the decision making stage of the robot. The results show the importance of method, by the design evolution. Also, maintenance that were necessary during the tests in the application of the case study.
\end{abstract}

Keywords: Software Engineering, User Centred Design, Service Robotics, Human-Robot Interaction, Personas 



\section{LISTA DE ILUSTRAÇÕES}

Ilustração 1 - Zonas de Proximidades . . . . . . . . . . . . . . . . . . . . . . . . . 34

Ilustração 2 - Os robôs Chester e Blink. . . . . . . . . . . . . . . . . . . 45

Ilustração 3 - Modelo de processo para IHR proposto nesta tese com base no modelo espiral. . . . . . . . . . . . . . . . . . 67

Ilustração 4 - Detalhamento do processo apresentado no método proposto por essa tese. 68

Ilustração 5 - Visão geral da sequência de passos da fase de concepção. . . . . . . . . . . 68

Ilustração 6 - Visão geral da sequência de passos da fase de construção. . . . . . . . . . . 82

Ilustração 7 - Exemplos das faces apresentadas pelo robô. . . . . . . . . . . . . . . . 90

Ilustração 8 - Ilustração do contexto de uso . . . . . . . . . . . . . . . . . . . . . . 91

Ilustração 9 - Cenário para teste de interação com o robô. . . . . . . . . . . . . . . . . 99

Ilustração 10-Robô ActivMedia Robotics PeopleBot. . . . . . . . . . . . . . . . . . . . 101

Ilustração 11 -Projeto do Novo Manipulador do PeopleBot. . . . . . . . . . . . . . . . . 102

Ilustração 12 -Projeto da Cabeça para o PeopleBot. . . . . . . . . . . . . . . . . . . . . 102

Ilustração 13 -Robô Judith na sua montagem final. . . . . . . . . . . . . . . . . . . . . 103

Ilustração 14-Ilustração do funcionamento do ROS. . . . . . . . . . . . . . . . . . . . 104

Ilustração 15 - Arquitetura do projeto para o classificador Bayesiano. . . . . . . . . . . . 105

Ilustração 16-Arquitetura de componentes que representam os softwares construídos no pacote approach_control. . . . . . . . . . . . . . . . 106

Ilustração 17 - Rede bayesiana construída para auxiliar no diagnóstico e avaliação da experiência do usuário na interação com o robô. . . . . . . . . . . . . . 116

Ilustração 18 -Rede bayesiana implementada no programa SamIam. . . . . . . . . . . . 117

Ilustração 19-Conforto por gênero. . . . . . . . . . . . . . . . . . . . . 121

Ilustração 20-Conforto por idade. . . . . . . . . . . . . . . . . . . . . . 122

Ilustração 21 -Conforto por posição de interação. . . . . . . . . . . . . . . . . . . . . 122

Ilustração 22 -Medo por gênero. . . . . . . . . . . . . . . . . . . . . . . . 124

Ilustração 23 -Medo por idade. . . . . . . . . . . . . . . . . . . . . . . . . . . . 124

Ilustração 24 -Medo por posição de interação. . . . . . . . . . . . . . . . . . . . . 125

Ilustração 25 - TPC - alfredo . . . . . . . . . . . . . . . . . . . . . . . . 174

Ilustração $26-$ TPC - maria_eduarda . . . . . . . . . . . . . . . . . . . . 174

Ilustração $27-\mathrm{TPC}$ - manuel . . . . . . . . . . . . . . . . . . . 175

Ilustração $28-\mathrm{TPC}$ - danielo . . . . . . . . . . . . . . . . . . . 175

Ilustração $29-\mathrm{TPC}$ - joaquim . . . . . . . . . . . . . . . . . . 176

Ilustração $30-\mathrm{TPC}-$ ajuda . . . . . . . . . . . . . . . . . . . . . 176

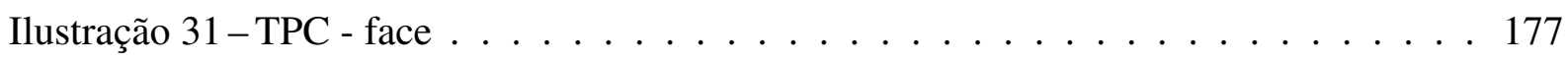

Ilustração $32-\mathrm{TPC}$ - face . . . . . . . . . . . . . . . . . . . . . . 177

Ilustração $33-$ TPC - fala . . . . . . . . . . . . . . . . . . . . . . . 177

Ilustração $34-\mathrm{TPC}-$ feedback . . . . . . . . . . . . . . . . . . . . . 178 


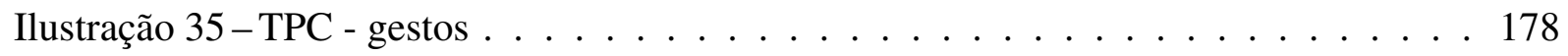

Ilustração $36-\mathrm{TPC}$ - padroes . . . . . . . . . . . . . . . . . . . . . 179

Ilustração 37 - TPC - posicao . . . . . . . . . . . . . . . . . . . . . 179

Ilustração $38-\mathrm{TPC}$ - posicao . . . . . . . . . . . . . . . . . . . . 179

Ilustração $39-\mathrm{TPC}$ - proximidade . . . . . . . . . . . . . . . 180

Ilustração $40-\mathrm{TPC}-$ reconhecer . . . . . . . . . . . . . . . . . . . . 180

Ilustração $41-\mathrm{TPC}$ - toque . . . . . . . . . . . . . . . . . . . 181

Ilustração $42-\mathrm{TPC}$ - velocidade . . . . . . . . . . . . . . . . . . 181

Ilustração $43-\mathrm{TPC}$ - conforto . . . . . . . . . . . . . . . . . . 182

Ilustração $44-\mathrm{TPC}$ - conforto . . . . . . . . . . . . . . . . . . . . . . 182

Ilustração $45-\mathrm{TPC}$ - desconforto . . . . . . . . . . . . . . . . . 182

Ilustração $46-\mathrm{TPC}$ - desconforto . . . . . . . . . . . . . . . . . 183

Ilustração $47-\mathrm{TPC}$ - desconforto . . . . . . . . . . . . . . . . . . 183

Ilustração $48-\mathrm{TPC}$ - desconforto . . . . . . . . . . . . . . . . . . . 183

Ilustração $49-\mathrm{TPC}-$ medo . . . . . . . . . . . . . . . . . . . . . . . 184 


\section{LISTA DE TABELAS}

Tabela 1 - Variáveis Comportamentais apresentadas por Mead e Maja J Matarić (2013) . 40

Tabela 2 - As 10 heurísticas de Nielsen . . . . . . . . . . . . . . . . . 54

Tabela 3 - 8 heurísticas de IHR baseada nos conjuntos de Nielsen e Scholtz . . . . . . . 56

Tabela $4-8$ heurísticas de IHRH adaptadas do conjunto de Nielsen . . . . . . . . . 57

Tabela 5 - Variáveis de observação escolhidas . . . . . . . . . . . . . . . . . . . . . . . . . . .

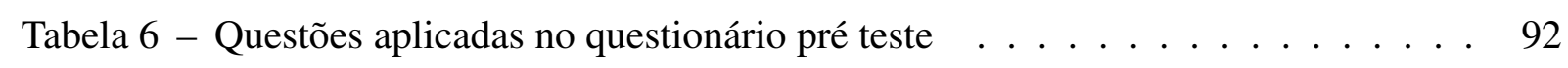

Tabela 7 - Questões aplicadas no questionário pós teste . . . . . . . . . . . 95

Tabela 8 - Divisão das amostras entre os participantes . . . . . . . . . . . . . 96

Tabela 9 - Funcionalidades do projeto de IHR . . . . . . . . . . . . . 97

Tabela 10 -Sensores e atuadores do projeto de IHR . . . . . . . . . . . . . . . 98

Tabela 11 - Persona Joaquim . . . . . . . . . . . . . . . . . . . . 109

Tabela 12 - Persona Maria Eduarda . . . . . . . . . . . . . . . . . . . . 110

Tabela 13 - Persona Alfredo . . . . . . . . . . . . . . . . . . . 111

Tabela 14 -Persona Danielo . . . . . . . . . . . . . . . . . . . . . 112

Tabela 15 - Persona Manuel . . . . . . . . . . . . . . . . . . . . . 113

Tabela 16 - Perfis dos 39 usuários que realizaram o teste piloto. . . . . . . . . . . . . 120

Tabela 17 - Expectativa do robô em casa dos perfis por Persona. . . . . . . . . . . . 126

Tabela 18 - Expectativa do robô no ambiente de trabalho dos perfis por Persona. . . . . . 127

Tabela 19-O que os perfis mais gostaram e menos gostaram separados por Persona. . . . 128

Tabela 20 - Desconforto dos perfis na interação, separados por Persona. . . . . . . . . . 128

Tabela 21 - Perfis dos 16 usuários que realizaram o teste de validação. . . . . . . . . . 130 



\section{SUMÁRIO}

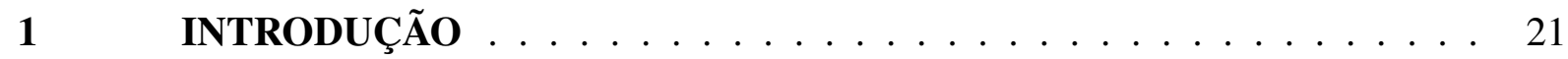

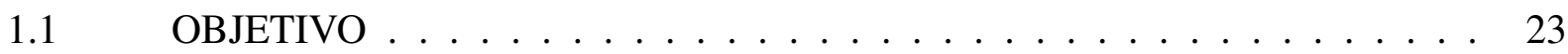

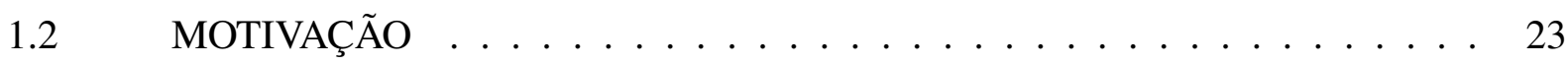

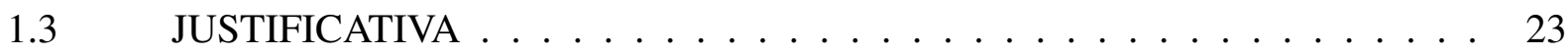

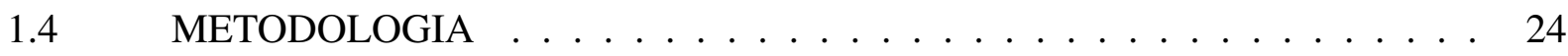

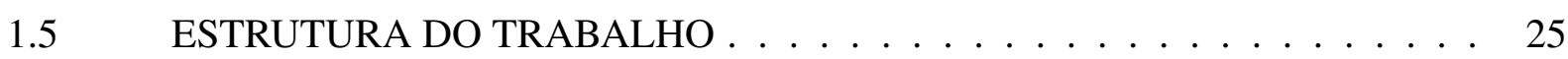

2 INTERAÇÃO HUMANO-ROBÔ $\ldots \ldots \ldots \ldots \ldots \ldots$

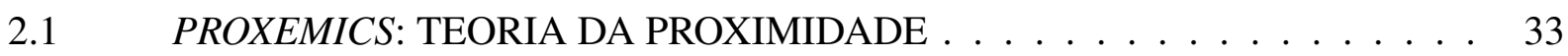

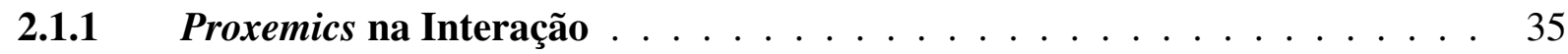

3 EXPERIÊNCIA DE USUÁRIO . . . . . . . . . . . . . . . . . . . . . . . . 49

$3.1 \quad$ Entendendo o usuário utilizando Personas . . . . . . . . . . . . . . 52

3.2 Avaliando a interação com o usuário . . . . . . . . . . . . . . 53

3.3 A experiência de usuário em interações com robô . . . . . . . . . . . . . 54

4 MÉTODO CENTRADO NO USUÁRIO PARA PROJETOS DE INTERAÇÃO HUMANO-ROBÔ $\ldots \ldots \ldots \ldots \ldots \ldots \ldots$

4.1 CONCEPÇÃO DO PROJETO DE INTERAÇÃO HUMANO-ROBÔ _ . . . . 68

4.1.1 Escopo do Projeto de Interação Humano-Robô . . . . . . . . . . . . . . . . 69

4.1.2 Variáveis de Observação _... . . . . . . . . . . . . . . . . . . . . . . . 69

4.1.2.1 Variáveis Etnográficas . . . . . . . . . . . . . . . . . . . 71

4.1.2.2 Variáveis Comportamentais . . . . . . . . . . . . . . . . 72

4.1.2.3 Variáveis do Robô . . . . . . . . . . . . . . . . . . . . . . . . . . . . . . . 74

4.1.2.4 Variáveis de Ações na Interação . . . . . . . . . . . . . . . . . . . . . 75

4.1.3 Contexto de Uso . . . . . . . . . . . . . . . . . . . . . . . . . . 76

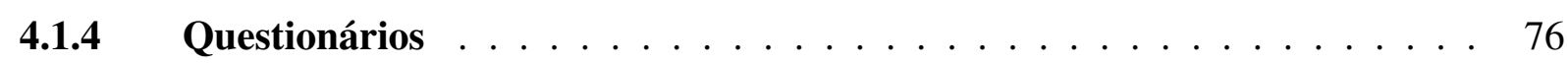

4.1.5 Seleção do Grupo de Perfis de Teste . . . . . . . . . . . . . . . . . . 77

4.1.6 Funcionalidades . . . . . . . . . . . . . . . . . . . . . . 78

4.1.7 Sensores e Atuadores $\ldots \ldots \ldots$. . . . . . . . . . . . . . . . 80

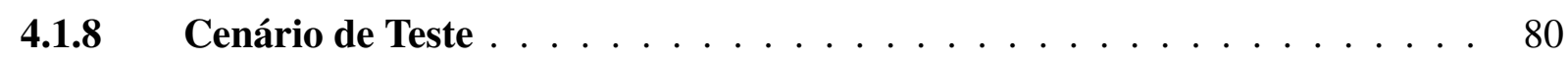

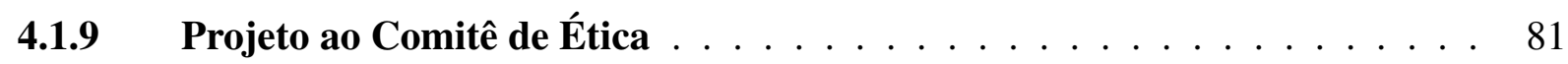

4.2 CONSTRUÇÃO DO PROJETO DE INTERAÇÃO HUMANO-ROBÔ . . . . . 82

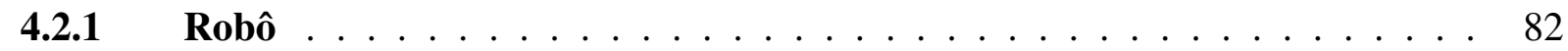

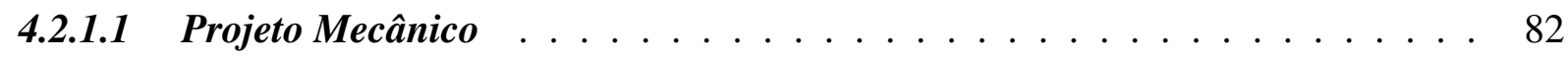

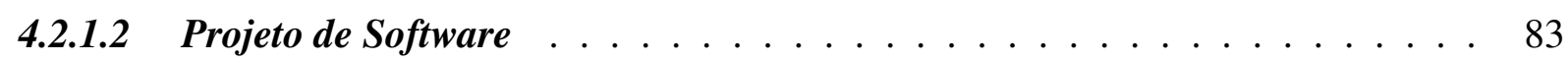

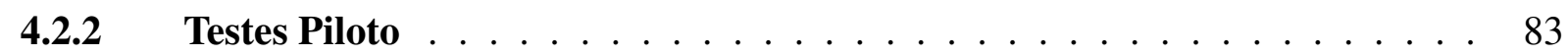

4.2.3 Criação das Personas . . . . . . . . . . . . . . . . . . . . . . . . . 84

4.2.4 Tomada de Decisão $\ldots \ldots \ldots \ldots$

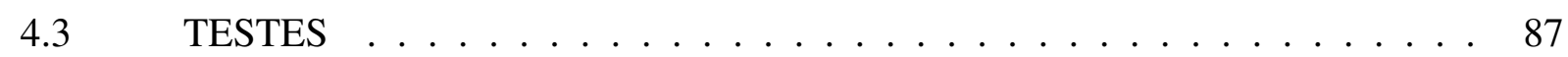




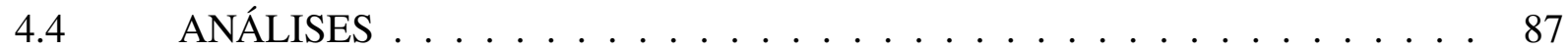

$5 \quad$ ESTUDO DE CASO $\ldots \ldots \ldots \ldots$

5.1 VARIÁVEIS DE OBSERVAÇÃO $\ldots \ldots \ldots \ldots$

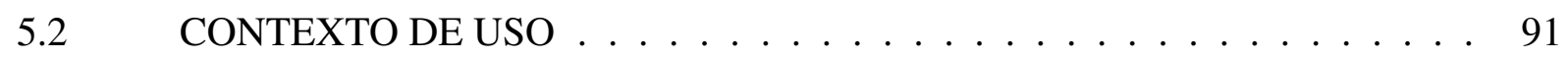

5.3 QUESTIONÁRIO PRÉ TESTE . . . . . . . . . . . . . . . . . 92

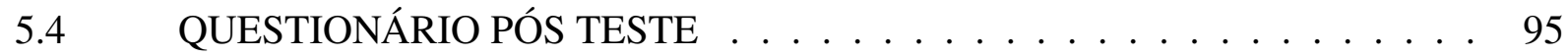

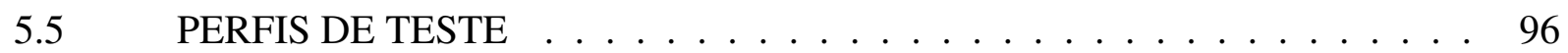

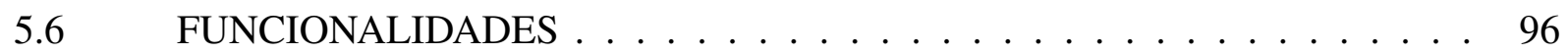

5.7 SENSORES E ATUADORES . . . . . . . . . . . . . . . . . . . . . 97

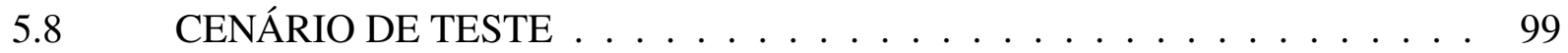

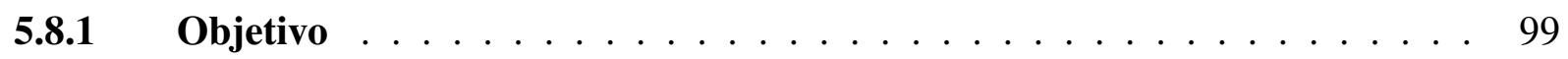

5.8.2 Estados de Comportamento do Humano . . . . . . . . . . . . . . . . . . 99

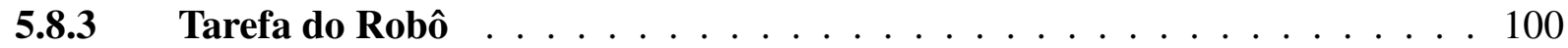

5.9 PREPARAÇÃO DO ROBÔ . . . . . . . . . . . . . . . . 100

5.9.1 Arquitetura do Software . . . . . . . . . . . . . . . . . . . . . 104

5.9.2 Bibliotecas . . . . . . . . . . . . . . . . . . . . . . . 106

5.10 TESTES PILOTO . . . . . . . . . . . . . . . . . . . . . . . 107

5.10.1 Heurísticas de Interação Humano-Robô $\ldots \ldots \ldots 7$

5.11 CRIAÇÃO DAS PERSONAS . . . . . . . . . . . . . . . 108

5.12 TOMADA DE DECISÃO: CLASSIFICADOR BAYESIANO . . . . . . . . 110

5.12.1 Definindo os valores de probabilidades condicionais . . . . . . . . . . 115

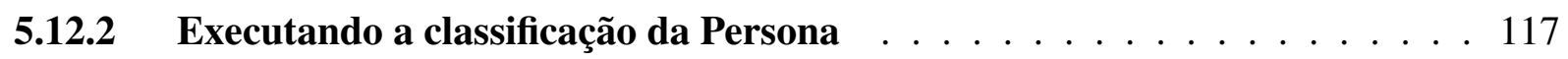

$6 \quad$ RESULTADOS E DISCUSSÕES . . . . . . . . . . . . . . . . . . . . . . . . 119

7 CONCLUSÕES E TRABALHOS FUTUROS . . . . . . . . . . . . . 135

REFERÊNCIAS . . . . . . . . . . . . . . . . . . . . . 138

APÊNDICE A - PROJETO AO COMITÊ DE ÉTICA . . . . . . . . . 153

APÊNDICE B - TABELAS DE PROBABILIDADES CONDICIONAIS . . 173 


\section{INTRODUÇÃO}

Com o passar dos anos é possível acompanhar a evolução dos sistemas computacionais, como por exemplo os telefones móveis, os computadores pessoais e portáteis, as televisões, e também os robôs pessoais, como o aspirador de pó iRobot Roomba ${ }^{1}$ e o assistente pessoal $\mathrm{JIBO}^{2}$. A evolução dos telefones móveis inteligentes mostra uma alta capacidade na realização de processamento de informações para executar diversas tarefas no dia a dia. Os componentes eletrônicos que compõem os aparelhos também diminuiram o tamanho. Isso permite que os aparelhos sejam mais finos, leves e com maior capacidade de processamento. Há também a inserção de robôs móveis em ambientes sociais, como as casas, hospitais e hotéis, unidos ao cenário da internet das coisas (HEENAN et al., 2014). Esses robôs são chamados de robôs de serviços. Segundo o International Federation of Robotics $(I F R)^{3}$, o ápice de robótica de serviço ocorrerá em 2020. Em 2016, a indústria de robótica de serviço movimentou $\$ 40$ bilhões.

A robótica de serviços abrange todos os ramos que não envolvem a indústria propriamente dita. A robótica de serviços possui desde robôs pessoais e domésticos até robôs de aplicações profissionais. Alguns exemplos de aplicações profissionais abrangem áreas como defesa, medicina, agricultura, pecuária, logísticas, entre outros, ou seja, qualquer robô que utilizado em ambiente não industrial. Segundo a IFR, de 2018 a 2020 é esperado um crescimento de 400 mil unidades, ou seja, entre 20 a $25 \%$ ao ano.

A área de maior crescimento é a de logística com o crescimento por ano de 189.700 unidades. Quando fala-se de valores monetários o crescimento é de $\$ 26,8$ bilhões no mesmo período. Ao falar de investimentos a área médica é a que possui um valor de projetos de $\$ 7,8$ milhões. De uma certa forma, isso auxilia na popularização dos projetos em robótica de serviço.

A popularização da robótica tem crescido também pela depreciasão de componenentes comuns de tecnologia, como câmeras, computadores, sensores de distância, e tablets. Esse fenômeno faz com que pesquisadores e fabricantes investiguem a necessidade de robôs inteligentes, que possuam a habilidade de interagir com as pessoas. Com a popularização do contato na interação humano-robô aumentará a necessidade de criar projetos com robôs que atendam as necessidades de cada usuário (LOOI; SEE, 2012). Isso torna a interação entre robôs e seres humanos importante, não apenas pela questão social, mas também porque uma boa interação passa a ser uma questão essencial para a convivência entre humanos e robôs. Ao considerar que robôs encontram-se em ambientes sociais inteligentes como casas, hospitais, escolas, hotéis, investigar o desenvolvimento de robôs sociais é fundamental (ALBO-CANALS et al., 2013; BROWN; KERWIN; HOWARD, 2013).

Um robô móvel inteligente possui várias maneiras de interagir. É capaz de identificar alguns padrões e ainda ter um nível de autonomia para tomada de decisões. O robô realiza as tarefas de interação através de sensores e atuadores espalhados em sua estrutura. Alguns

\footnotetext{
${ }^{1}$ http://www.irobot.com/For-the-Home/Vacuum-Cleaning/Roomba.aspx

${ }^{2}$ https://www.jibo.com/

${ }^{3}$ https://ifr.org/
} 
sensores utilizados na construção dele são câmeras, infravermelhos, laser, de profundidade, térmicos, entre outros. Os atuadores são todos os dispositivos que possam gerar interação, externando algo para o indivíduo, seja através de um movimento, uma imagem ou até mesmo algum sinal sonoro. Alguns exemplos de atuadores são: tablets, caixas de som, manipuladores e motores (LOOI; SEE, 2012; CHOI; KIM; KWAK, 2014; DOBRA, 2014).

Apesar da popularização e de pesquisas voltadas para a robótica de serviços, a documentação e formalização dos passos do projeto de interação humano-robô são pouco aplicados. Projetos de interação humano-robô não possuem um nível de detalhe e preocupação para que o robô seja melhor aceito pela sociedade (ALENLJUNG et al., 2017). Técnicas de engenharia de software e usabilidade, principalmente projetos centrados no usuário, disseminada na comunidade de pesquisadores de interação humano-computador, são pouco aplicadas em projetos voltados para robôs autônomos para interações sociais (ALENLJUNG et al., 2017).

Com o uso das técnicas adequadas é possível estabelecer passos para construção de robôs, com uma boa especificação, podendo reproduzi-lo e reaproveitar o projeto em diversos cenários. Além disso, a manutenção do robô também é favorecida com o método utilizado em sua construção é adequado, assim como sua evolução para versões mais robustas. Quando cenários de interação social são analisados, o ponto chave é manter as pessoas na interação confortáveis e sem medo de uma aproximação ou abordagem de qualquer agente envolvido, seja robô ou ser humano. No caso do ser humano, é necessário conhecer o perfil do usuário em questão, e estabelecer ações que auxiliem a manter o seu nível de conforto e assim manter uma interação de longa duração.

Para aumentar as possibilidades de reutilização, manutenção e evolução desses projetos, é necessário, criar de maneira sistêmica, toda a documentação com a especificação do robô (hardware e software). Sendo assim, essa tese apresenta um método centrado no usuário para a construção de um projeto de interação humano-robô autônoma possibilitando uma melhor manutenção e melhorias do projeto sempre visando uma interação social de qualidade. Questões que são abordadas durante a construção do projeto são: hardware, software, contexto de uso, cenário de testes, participantes de testes, funcionalidades do robô, entre outros. Como o projeto é centrado no usuário, é importante traçar as características do perfil deste usuário para detectar melhor as suas necessidades e preferências.

A técnica utilizada para identificar o perfil do usuário neste trabalho é a de Personas. Personas são arquétipos hipotéticos que representam um grupo de usuários reais através de um personagem fictício (AQUINO JUNIOR; FILGUEIRAS, 2005; MASIERO et al., 2011). A técnica de Persona é importante, pois o alcance em número de perfis é alto e a quantidade de personagens é bem menor. Isso torna a comunicação e as tomadas de decisões centradas no usuário mais fácil, do que olhando perfil a perfil. Assim, o método proposto aqui, utiliza a técnica de Persona para garantir as preferências do usuário durante a construção do projeto.

Para demonstrar o uso do método proposto é realizado um estudo de caso para a construção de um robô autônomo, que realiza a classificação do perfil do usuário através de uma rede 
Bayesiana. O classificador apresentado nessa tese, é um classificador Bayesiano que utiliza informações sobre as ações do robô, comportamentais, cenário e de percepção sobre heurísticas de avaliação de usabilidade, para identificar o perfil do usuário definido como Personas. A partir da classificação é possível identificar ações que o robô deve realizar para melhorar a interação com o usuário. Essa evolução do estudo de caso é apresentada como um novo ciclo do método proposto para a construção do robô.

\subsection{OBJETIVO}

Como objetivo esta tese propõem a construção de um método sistêmico para projetar e desenvolver um robô totalmente autônomo e centrado no usuário para interação social.

\subsection{MOTIVAÇÃO}

$\mathrm{O}$ crescente número de pesquisas em robótica aplicados em ambientes sociais como casas, hospitais e escolas fazem com que seja um tópico de atenção entre os pesquisadores. Esse é um tópico importante, pois os diferentes formatos existentes de robôs podem gerar problemas de confiabilidade. Esse é um ponto que pode determinar o conforto do usuário ao estar em mesmo ambiente que o robô. Por consequência, a questão da confiabilidade pode determinar a aceitação do robô.

Para mitigar esse problema, vários fatores devem ser analisados. Fatores como o perfil do usuário na interação social e também as características do projeto do robô. Todas essas informações são consideradas para que o robô possa predizer quais são as melhores ações de interação com um determinado indivíduo. Encontrar uma solução para esse problema é uma tarefa complexa. Deve-se considerar a coleta e o processamento dessas informações para a tomada de decisão correta, o que em muitas vezes é necessário sensores dedicados a uma tarefa específica, como o sensor de profundidade.

O custo de processamento dessas informações pode ser alto para o robô pois, sua infraestrutura tem uma capacidade computacional e eletrônica que limita a tarefa. Sendo assim, é necessário que exista uma arquitetura de sistema capaz de considerar a manutenção e expansão dos equipamentos utilizados na construção do robô. Assim, é possível fazer com que o robô evolua ao longo do tempo.

\subsection{JUSTIFICATIVA}

Durante os estudos de trabalhos que realizam a análise de comportamento humano através de robôs aplicados principalmente em robótica social, notou-se que existem poucos estudos voltados ao projeto de interação humano-robô e aplicações que atendam as necessidades do usuário de maneira sistêmica. Além disso, alguns trabalhos (OKITA; NG-THOW-HING; SAR- 
VADEVABHATLA, 2012; HENKEL, Zachary; MURPHY, R. R.; BETHEL, 2012; VÁZQUEZ et al., 2014) utilizam a técnica de Wizard of OZ (WoZ) para realizar os testes com humanos. Essa técnica condiz com o controle do robô de maneira remota, como se este fosse totalmente autônomo. Esse tipo de técnica, não consegue transmitir de maneira adequada o comportamento do robô, uma vez que ela não consegue trabalhar com os ruídos dos sensores e problemas encontrados durante uma navegação autônoma, como combinação do mapa ou detecção de obstáculos e pessoas. Tudo isso é realizado pelo operador em posse do controle remoto, tirando a naturalidade e autenticidade da interação do robô.

Assim, é necessário a criação de um método que seja capaz de construir um robô possa, de maneira autônoma, realizar diversas tarefas e tomadas de decisão durante interação, de maneira sistêmica. Essa pesquisa é importante para que haja uma evolução dos ambientes inteligentes, principalmente os que consideram o robô como um agente. Além da evolução dos ambientes inteligentes, manter o indivíduo com a melhor experiência de interação com o robô, e também faze-lo confortável com a presença do robô.

\subsection{METODOLOGIA}

A fundamentação do trabalho é realizada em pesquisas de cada uma das áreas abrangentes, interação humano-robô (IHR), conceito de proxemics, experiência de usuário aplicado a IHR, onde identificou-se a necessidade da criação de um projeto sistêmico para IHR. A partir desse projeto é possível determinar os passos para a construção do robô, especificação do contexto de uso, perfil de usuários para interação, e ferramentas de testes. O projeto foi submetido ao comitê de ética o projeto para aprovação dos testes com seres humanos.

A primeira bateria de testes foi realizada. A partir dos resultados dos testes piloto, é aplicado o algoritmo QG-SIM para construção dos grupos de perfis similares. Com cada grupo identificado, são criadas as Personas que devem ser classificadas pelo robô com base nas informações obtidas através das variáveis de observação identificadas na fase de concepção do método proposto. A partir desse ponto, é realizado um estudo de caso para viabilizar a aplicação do método na construção real de um projeto de interação humano-robô. As variáveis e observações feitas durante os testes pilotos são utilizadas para determinar as variáveis que compõem o classificador. Para o classificador é utilizado a técnica probabilística, rede Bayesiana. O objetivo é eliminar repetição das dependências condicionais apresentadas na construção da estrutura da rede.

Na sequência novos testes são realizados, para que seja possível a validação do classificador e das questões referentes ao perfil do usuário, demonstrando as fases de teste e análise do método proposto. O cenário de teste utilizado é um ambiente simulado de residência, onde o robô habita com mais uma pessoa. Realizados os testes, os resultados são analisados e discutidos, apresentando as estatísticas e observações obtidas durante o processo. Por fim, os próximos passos para o projeto são apresentados. 


\subsection{ESTRUTURA DO TRABALHO}

Esta tese é composta por um total de 7 capítulos discriminados a seguir.

O capítulo 1 apresenta a introdução do trabalho conduzindo o leitor ao problema que a pesquisa desta tese deve contribuir.

O capítulo 2 introduz a área de interação humano-robô, contando um pouco da história e sua importância para o futuro.

O capítulo 3 introduz a área de interação humano-computador, apresentando os principais conceitos para o desenvolvimento de um sistema centrado no usuário. Também é apresentado trabalhos que aplicam as técnicas em cenários de interação humano-robô.

O capítulo 4 apresenta a especificação do método para construção de um projeto em interação humano-robô apresentado para a construção de robô de serviço autônomo.

O capítulo 5 apresenta um estudo de caso através da criação de um classificador para demonstra a aplicação do método proposto por esta tese.

O capítulo 6 apresenta os resultados e discussões desta tese.

O capítulo 7 apresenta as conclusões e trabalho futuros obtidos ao longo dos estudos e testes dessa tese. 



\section{INTERAÇÃO HUMANO-ROBÔ}

Interação Humano-Robô (IHR) é a área de estudo que procura compreender, avaliar e implementar robôs para que possam trabalhar em conjunto ou executar uma determinada tarefa onde a interação com o ser humano ocorra. A interação deve ser menos invasiva e mais colaborativa. O primeiro guia da IHR apareceu no conjunto de trabalhos de ficção científica de Isaac Asimov (ASIMOV, 2004), que é apresentado como as primeiras leis da robótica por diversos pesquisadores e intusiadas sobre o tema. A primeira lei fala que um robô não pode ferir um ser humano e também deve protegê-lo para que nenhum mal o seja causado. A segunda lei diz que um robô deve obedecer as ordens dadas por seres humanos exceto nos casos que às ordens entrem em conflito com a primeira lei. E por fim a terceira lei diz que um robô deve proteger sua própria existência desde que não entre em conflito com a primeira e/ou segunda leis. Essas leis regem os trabalhos em IHR até os dias atuais (GOODRICH; SCHULTZ, 2007; WEISS, 2010).

Qualquer tipo de robô possui um nível de interação, mesmo os completamente autônomos. O nível de interação descreve qual o grau de ação do robô a partir de sua própria iniciativa. A interação pode ocorrer de duas maneiras específicas: Interações Remotas (robôs e humanos em diferentes locais espaço-temporais), por exemplo, a operação do robô Curiosity ${ }^{1}$ em Marte e a NASA no planeta Terra; Interações Próximas (robôs e humanos estão no mesmo local, compartilhando o mesmo espaço), por exemplo, em indústrias ou residências como o robô Roomba (GOODRICH; SCHULTZ, 2007).

Robôs teleoperados são guiados por controles, como por exemplo joysticks de vídeo games. Já os robôs completamente autônomos devem reconhecer o ambiente, o cenário de atuação, agentes existentes no ambiente e os que estão direcionando-o para o seu objetivo final, além de atualizar constantemente esses dados e as restrições competentes. Alguns trabalhos são direcionados a interação através de um controle ou uma central de comando com a operação de um ser humano, mas a quantidade de trabalhos com robôs autônomos vêem crescendo principalmente em pesquisas de robótica assistiva e robótica para resgate em catástrofes, onde existem riscos a vida (GOODRICH; SCHULTZ, 2007; WEISS, 2010).

IHR é um estudo que necessita da participação de diversas outras áreas de pesquisa, como Ciências Cognitivas, Linguística, Psicologia, Antropologia, Engenharia, Ciências da Computação, Matemática, Engenharia dos Fatores Humanos e Design. Essas áreas de pesquisa contribuem com técnicas para o robô, fazendo com que este caminhe para comportamentos mais naturais. Um exemplo é a teoria de proximidade originada por Hall (1969) na área de antropologia. Essa teoria determina zonas de proximidades entre agentes em processo de interação. A teoria definida por Hall (1969) é utilizada como base para os testes apresentados nessa tese (seção 2.1), uma vez que apresenta variáveis que são importantes para trabalhar a análise de comportamento do usuário perante o robô. É importante também, o estudo de padrões de

\footnotetext{
${ }^{1}$ https://www.nasa.gov/mission_pages/msl/index.html
} 
interação adotando pequenas perspectivas sobre soluções de problemas condizentes com a pesquisa, tornando mais fácil encontrar meios de corrigir um problema recorrente (GOODRICH; SCHULTZ, 2007).

Uma definição para interação é a atividade de trabalhar em conjunto para o mesmo objetivo. A IHR é afetada por cinco fatores de interação, que são: (I) Nível e comportamento de autonomia; (II) Troca natural de informação; (III) Estrutura do time; (IV) Adaptação, aprendizado e treinamento de pessoas e robôs; e (V) Formato das tarefas (GOODRICH; SCHULTZ, 2007). Trabalhos relacionados a cada um dos fatores de interação são apresentados a seguir.

Um robô que possui um grau de autonomia, consegue manter-se desatento por um período de tempo e continuar sua tarefa no mesmo ponto que parou. Contudo, em IHR a autonomia não é considerada com um resultado final, mas sim um meio que auxilia o processo de interação (GOODRICH; SCHULTZ, 2007; WEISS, 2010).

O nível de autonomia de um robô determina o quanto esse pode agir por conta própria. Existem diversas formas de medir e analisar esse nível. O mais utilizado é a escala de Sheridan (SHERIDAN; VERPLANK, 1978) que apresenta um intervalo continuo, desde um robô que não realiza nenhuma tarefa por conta própria (robô teleoperado), até um robô totalmente independente e autônomo. Apesar do grande uso da escala de Sheridan, sua aplicabilidade a um cenário de tarefa grande e complexo não é muito eficiente, pois possui um nível de abstração que não possibilita investigar muitos detalhes. O trabalho com muitas informações pode gerar resultados tendenciosos ao estudo. Aconselha-se utilizar a escala dividindo o cenário em subtarefas (GOODRICH; SCHULTZ, 2007; WEISS, 2010).

Em IHR o nível de autonomia é melhor determinado por uma combinação entre o nível de interação com o humano e o quanto ambos, robô e pessoa, conseguem realizar tarefas de forma independente. O desenvolvimento de habilidades cognitivas é importante para o robô interagir com o humano de maneira natural e eficiente. Nos anos 80, Brooks apresentou um novo paradigma para autonomia de robôs, conhecida como robôs baseados em comportamento (BROOKS, R., 1986; BROOKS, R. A., 1991). Outro modelo chamado de sinta-pense-aja também é apresentado na literatura como uma arquitetura híbrida que apresenta um problema de desenvolver comportamentos naturais e atividades robustas para robôs humanoides. Devido a isso, as áreas que trabalham no modelo cognitivo de aprendizagem e tomada de decisão tem crescido cada vez mais (GOODRICH; SCHULTZ, 2007).

Indivíduos em contextos sociais de interação reconhecem outras pessoas e eles mesmo através das emoções. Essa capacidade é definida como inteligência emocional. O tratamento de inteligência emocional em trabalho de IHR tendem a tornar as tarefas realizadas mais naturais. Rani, Liu e Sarkar (2006) apresentam um modelo dos efeitos fisiológicos e correlaciona com os psicofisiológicos para que o robô seja capaz de inferir sobre o efeito da ansiedade nas pessoas. A partir desse modelo foi possível incentivar a melhoria no desempenho de pessoas que tentavam fazer cestas em um jogo de basquete. 
Giovannangeli e Gaussier (2007) apresentam um modelo de IHR onde o robô é capaz de aprender tarefas a partir de uma pessoa realizando o papel de treinador, onde o robô reproduz seus movimentos e consegue armazená-lo para situações futuras. No mesmo sentido, um trabalho com o robô Pepper da Softbank é apresentado por Kitagawa et al. (2016). Nesse trabalho é realizado um controle de sleep antes da reprodução dos gestos. Esse controle auxiliou na naturalidade da execução dos gestos e também um fato curioso, foi que a pessoa reproduzindo os gestos muitas vezes acabava por imitar o robô.

Outro fator importante para IHR é a aparência do robô em conjunto com a capacidade de execução de tarefas esperada para àquela aparência. Dessa maneira, Minato et al. (2007) apresentam uma plataforma robótica em formato de uma criança, mais precisamente um bebê, para realizar estudos de interação e principalmente a capacidade da cognição do robô durante a interação.

Teorias de psicologia também são aplicadas em trabalhos de IHR. Um exemplo é a teoria da mente que auxilia o robô na análise do comportamento de um indivíduo e possibilita a tomada de decisão para uma interação próxima a natural. $\mathrm{O}$ uso da teoria da mente faz com que o robô tente se colocar no lugar da outra pessoa, para identificar qual seria seu comportamento em uma determinada situação. Esse é um princípio utilizado por seres humanos ao interagir e se preocupando com o estado emocional da outra pessoa (HIATT; HARRISON; TRAFTON, 2011). Assim como a teoria de ação, definida por Norman, que auxilia na definição de emoções humanas com base em ações tornando o comportamento do robô mais natural ao do ser humano. Em linhas gerais, a teoria de ação possui sete passos. Definição de um objetivo geral para ação, a partir do objetivo é estabelecida uma ação imediata, que para executá-la é necessário uma sequência de ações. Após a execução da sequência de ações, deve-se perceber qual é o estado resultante. Assim, interpreta-se o que foi percebido e com a interpretação é realizado uma avaliação se a ação imediata foi atingida ou não (TOUMI; ZIDANI, 2013).

Utilizando um sensor de movimento Kinect foi criado uma plataforma de teste para interação humano-robô, onde o ser humano pode treinar o robô a distância e sem necessidade de contato físico. A ideia é poder fazer com que o robô não cause dano físico à pessoa e por consequência diminuir o medo de interação em participação de testes. A plataforma apresentada por Rossmann et al. (2013) transmite em tempo real o conhecimento dos gestos para o robô e este é reproduzido fielmente.

Briggs, Scheutz e Tickle-Degnen (2015) apresentam um estudo para auxiliar o tratamento de pessoas com a doença de Parkinson. Com essa doença o paciente pode perder a funcionalidade dos músculos faciais, levando assim a perda das expressões faciais. Quando um enfermeiro ou médico vai realizar o tratamento do paciente, pode interpretar que ele está desdenhando ou com nojo do profissional. A utilização do robô soluciona esse problema, já que o robô é capaz de filtrar as expressões faciais. Nos testes apresentados, os pacientes sentiram-se confortáveis com a interação junto ao robô NAO da Aldebaran. 
Trabalhos colaborativos são explorados entre os trabalhos de IHR. Strohkorb e Scassellati (2016) exploram um meio de fazer com que o robô consiga promover a colaboração entre dois seres humanos a realizar uma tarefa. É utilizado um robô chamado MyKeepon para auxiliar duas crianças a colaborarem entre si durante um jogo de celular. Os primeiros passos foram dados e aparentemente foi possível fazer com que elas colaborassem durante o jogo. O próximo passo é a criação de um mecanismo de raciocínio de alto nível que seja capaz de manter grupo de pessoas já observados.

É apresentado por Lampe et al. (2016), um sumário sobre um painel que ocorreu em um congresso, que discuti o tema sobre como os robôs irão interagir, cooperar e colaborar com seus respectivos donos em diversas situações sociais. No painel é discutido que o trabalho em formato de time deverá ser abordado com mais frequência. Nesse cenário a comunicação verbal é essencial e precisam de mais estudos para interpretação semântica de fala e estilo de voz para cada situação.

Alguns trabalhos já apresentam a integração com outros tipos de técnicas para demonstrar como que o robô pode assumir a liderança na tarefa ou apenas seguir as instruções da pessoa. Um trabalho nessa direção é apresentado por Li et al. (2015) que utiliza a teoria de jogos para solucionar o problema de líder ou seguidor na IHR. Nesse problema o robô deve saber qual a situação que ele deve dar uma ordem a pessoa que está próximo dele, e em qual situação ele deve seguir as ordens das pessoas que interagem com ele. É um problema de colaboração em time, sem hierarquia definida.

Sistemas de detecção de anomalias com o propósito de servir idosos e pessoas com problemas físicos que vivem sozinhos é outro tema explorado. Após a detecção da anomalia com base no padrão de interação com o ambiente dessa pessoa, as entidades de assistência domésticas são acionadas e o processo de socorro da pessoa é iniciado. Para que esse trabalho atingisse uma boa acurácia (entre $80 \%$ e $85 \%$ ), um robô móvel é utilizado em conjunto com sensores no ambiente de uma casa inteligente para detecção das anomalias (LUNDSTRÖM; MORAIS; COONEY, 2015).

Diversos estudos são desenvolvidos em torno de edifícios inteligentes, com o intuito de robôs estarem cada vez mais presentes em tarefas do dia-a-dia. Entretanto, robôs e seres humanos possuem percepções diferentes do ambiente. Para melhor entender a diferença entre as percepções de cada um, com foco em ambientes internos, uma área chamada de mapeamento semântico vêm ganhando evidência na literatura. Esse mapeamento utiliza a detecção de objetos no ambiente com o intuito de inferir a localização do robô em residências e edifícios (TUREK; CETNAROWICZ; BORKOWSKI, 2017).

Turek, Cetnarowicz e Borkowski (2017) criam um modelo baseado no utilizado por seres humanos, que tem como objetivo entender a planta de um edifício e como o robô realizaria para atingir a mesma percepção. Assim, o conhecimento pode ser compartilhado, aumentando a eficiência da comunicação e compreensão entre ambos para o ambiente. Essa compreensão aumenta a eficácia na navegação do robô pelo prédio. Como evolução do trabalho, Turek, 
Cetnarowicz e Borkowski (2017) querem gerar conhecimento a priori para o robô através de arquivos tipo CAD e também utilizando outros sensores espalhados na residência.

Houve um crescimento no número de trabalhos dedicados a área da educação em IHR. Martelaro et al. (2016) investigam métodos para criação de comportamento do robô com o objetivo de aumentar a confiança entre humanos que interagem com robôs. Duas medidas para o aumento da confiança são: vulnerabilidade e expressividade. Notou-se nos testes que robôs mais vulneráveis aumentam mais a confiança do que robôs mais expressivos. Os testes foram realizados com base em um robô tutor. Esse robô tem o formato de humanoide e tem o papel de um assistente do professor na sala de aula.

Outra proposta é identificar se crianças conseguem aprender melhor com o um tutor humano ou um robô. Estatisticamente, não houve significância considerável entre os dois resultados. Porém, o índice de Carson mostrou que o humano conseguiu ser melhor que o robô, principalmente na questão social. Um dos pontos que mais faltaram ao robô durante a interação com as crianças foi a questão de olhar mútuo. Apesar do estudo feito, não existe a ideia de substituir o ser humano com o robô, mas sim utilizar o robô como uma ferramenta complementar na sala de aula (KENNEDY et al., 2016).

Um questionário foi conduzido dentro de um hotel no Japão que utiliza robôs para alguns serviços. O objetivo é identificar se o robô é capaz de substituir uma pessoa nas tarefas. Entrevistaram em primeiro lugar o gerente do hotel e depois direcionaram as entrevistas às pessoas que tiveram maior contato com o robô no dia-a-dia. Chegou-se a conclusão de que robôs podem substituir o ser humano nas tarefas, porém esse é um trabalho que deve ser realizado de maneira bem planejada (OSAWA et al., 2017).

Um robô com aspecto de humanoide foi desenvolvido para fazer a patrulha de um shopping durante a noite e durante o dia servir de apoio aos visitantes. A área de segurança deve ser muito explorada, pois a quantidade de pessoas treinadas para executar esse trabalho tem diminuído e as empresas não estão conseguindo repor a necessidade do mercado. Como patrulha, o robô teve um desempenho esperado, só que a atuação como cartão de boas vindas ao shopping foi além do esperado. Os resultados mostraram que as pessoas tiveram empatia pelo robô e acabou fazendo com que ele atraísse mais consumidores ao shopping (LÓPEZ; CUÉLLAR, 2017). Isso demonstra que o robô pode apresentar múltiplas aplicações, apenas trocando as funções de seu programa.

Para que o robô seja capaz de realizar todas essas atividades, várias técnicas devem ser empregadas. Para realizar a personalização da interação do robô para cada pessoa, Suga et al. (2006) aplicam uma técnica de computação evolucionária interativa. Essa técnica funciona como um algoritmo evolucionário qualquer, porém a função fitness é dada pela avaliação direta da pessoa. Como meio de melhorar essa função, é apresentado uma função híbrida onde uma parte dos genes são modificados pela avaliação do usuário e outra parte modificado pelo próprio algoritmo usando como base as modificações manuais. Os resultados apontaram que o robô foi capaz de adaptar o comportamento de cada sujeito de teste. 
Outro algoritmo evolucionário é aplicado para melhorar a aparência do robô com a ajuda e retorno sobre o gosto da pessoa. A fase de seleção do algoritmo era feita sobre a preferência do usuário que avaliava uma versão digital da morfologia do robô. Após o estacionamento da aparência do robô na otimização feita pelo algoritmo, o robô era confeccionado (DE BEIR; VANDERBOGHT, 2016).

O uso da percepção sobre o olhar em uma interação entre humanos é comum e auxilia a melhorar a comunicação entre os indivíduos. A abordagem dessa característica é pouco utilizada em interação humano robô e geralmente é realizado com base apenas na orientação da cabeça. Utilizar a orientação da cabeça pode gerar um erro grande e uma noção de comunicação falha. Por isso, Palinko et al. (2016) desenvolveram um algoritmo de rastreamento do olho passivo com baixo custo para um robô humanoide. Os resultados apresentaram um bom rastreamento do movimento do olho. Agora estudos tendem a evoluir para o rastreamento da pupila e da posição da cabeça para melhorar a robustez do algoritmo.

Tratando-se de IHR é impossível não tratar a questão do contato físico entre os agentes. Com base nessa premissa, foi criado um modelo de controle de impedância, para reduzir e controlar a força do robô após o contato com qualquer superfície. É utilizado um sensor de RGB-D (Kinect) para identificar o ponto de contato e em seguida, é feito o planejamento do movimento. Caso haja um contato não planejado durante sua trajetória, o robô é capaz de identificar a pressão exercida, regulando assim a força exercida sobre a superfície mantendo a segurança na interação (MAGRINI; FLACCO; LUCA, 2015).

Outra questão investigada na interação com contato físico, é o efeito de um abraço dado por um robô de pelúcia gigante, sobre a vontade de fazer caridade das pessoas abraçadas. Os resultados não foram estatisticamente significantes, porém acredita-se que é necessário realizar uma investigação melhor sobre a relação entre o contato físico entre humano e robôs, e a vontade de realizar uma caridade (NAKATA et al., 2017).

É investigado também a questão sobre a preocupação com a segurança pessoal ou o custo financeiro dos danos causados pelo robô em caso de falha. Para conduzir o experimento alguns vídeos de situações e tarefas de interação humano-robô foram apresentados para pessoas. Após o vídeo elas avaliavam o grau de criticidade de cada situação. Os resultados apresentados são interessantes, pois as pessoas deram um nível maior de criticidade para o robô derrubando líquido no laptop do que ele esbarrar e machucar uma pessoa. Contudo, estudos mais realísticos devem ser efetuados (ADUBOR; ST. JOHN; STEINFELD, 2017).

Outras discussões têm sido endereçadas na questão de robótica social, assistiva e de serviço. Com robôs entrando em nosso dia-a-dia começa a preocupação sobre questões de invasão de privacidade das pessoas por parte dos robôs. Essas linhas de pesquisa têm ganhado força em debates da comunidade (RUEBEN et al., 2017). Discussões sobre a ética são muito importantes, pois ajudam a manter uma certa moralidade durante os experimentos e consequentemente sobre o produto lançado. Por isso, deve-se realizar uma avaliação perante ao comitê de ética an- 
tes de realizar qualquer experimento do projeto. Essa tese apresenta um método que aconselha a criação e submissão de avaliação do experimento ao comitê de ética.

Para a criação do projeto ocorrer, as variáveis que serão avaliadas e analisadas no experimento devem ser selecionadas de acordo com o objetivo do experimento. Se tratando de IHR, a teoria de proximidade apresenta diversas variáveis e análises que contribuem diretamente com o método proposto nesta tese. A seção 2.1 apresenta em mais detalhes a teoria de proximidade, com um foco em trabalhos utilizando robôs.

\subsection{PROXEMICS: TEORIA DA PROXIMIDADE}

As pessoas, quando convivem em sociedade, tendem a respeitar o espaço existente entre cada indivíduo. Esse fenômeno é determinado como espaço social, sendo este medido através da distância social que é um dos princípios fundamentais para uma interação social com qualidade (HALL, 1969; HENKEL, Z. et al., 2014). A análise do comportamento das pessoas e a relação da distância social entre os indivíduos foi definida por Hall (1969) como Proxemics. Proxemics é definida como processo dinâmico de interação entre dois agentes, onde eles fiquem posicionados frente a frente e/ou próximos entre si (MEAD; ATRASH; MATARIĆ, Maja J, 2011a).

Durante os estudos de Hall (1969), observou-se que a questão da distância social está diretamente ligada a cultura de cada indivíduo. Isso quer dizer que a percepção dessa distância entre pessoas que viveram em regiões distintas poderá ser diferente.

Com base na teoria de Hall (1969), pode-se ilustrar o seguinte cenário como exemplo: uma pessoa que vive no Brasil pode não se importar com os indivíduos muito próximos a ele. Em contrapartida, a pessoa que vive no Japão talvez tenha preferência por manter uma distância maior entre ele e as demais pessoas durante o processo interação. Além disso, variáveis como gênero e idade também influenciam na relação espacial de interação entre indivíduos.

Apesar da observação sobre as variáveis que podem influenciar na relação da distância social, Hall (1969) não formalizou nenhuma regra sobre a distância social para interações entre indivíduos. Assim, Argyle (1988) definiu quatro zonas de proximidades, formalizando regras para distância social nas interações entre indivíduos. São elas: (I) Zona de Proximidade Pública; (II) Zona de Proximidade Social; (III) Zona de Proximidade Pessoal; e (IV) Zona de

Proximidade Íntima. A figura 1 ilustra a definição de Argyle (1988) na formalização do espaço social.

Cada uma das zonas de proximidades apresentadas na figura 1 possui características particulares que pode guiar como ocorrerão as interações sociais. Na zona de proximidade social, o indivíduo pode emitir sons com maior volume do que a zona de proximidade íntima que, por estarem muito próximos os indivíduos acabam se comunicando com sons mais baixos ou até mesmo sussurros. Interações na zona íntima são esperadas normalmente entre amigos muito próximos ou entre casais (HALL, 1969; ARGYLE, 1988). O comportamento aceitável em zo- 
Figura 1 - Zonas de Proximidades

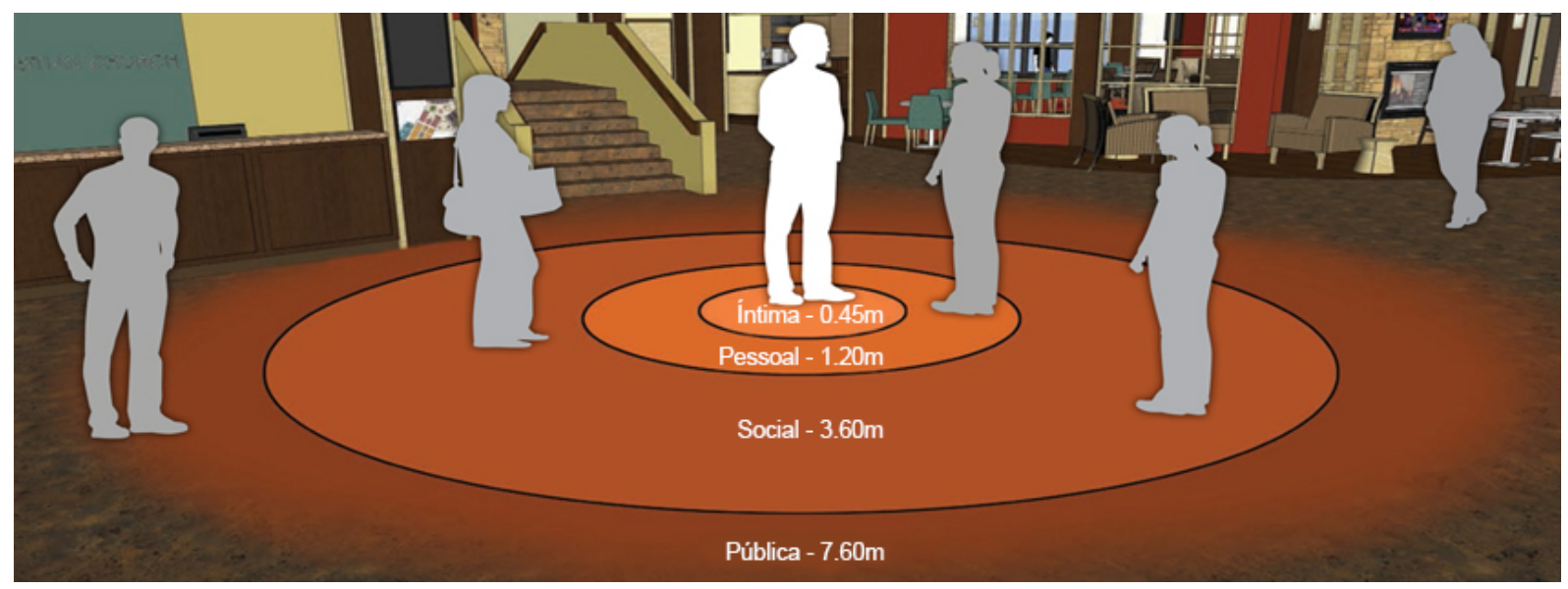

Fonte: Argyle (1988).

nas de proximidades mais distantes, como a social e a pública, é a comunicação com maior intensidade, movimentos mais amplos e até com uma força física maior que nas regiões mais próximas, onde há a probabilidade maior do indivíduo se assustar com esse tipo de comportamento (HENKEL, Z. et al., 2014).

Além dos comportamentos diferentes em cada zona de proximidade, existe um outro fator que pode atrapalhar a interação exclusiva entre duas pessoas nas regiões mais distantes. A existência de pessoas inseridas nas regiões mais distantes, pode dificultar o estabelecimento de uma interação exclusiva devido ao excesso de ruído no cenário. O ruído para esse cenário pode ser considerado através do volume excessivo de pessoas no local, junto com a altura dos sons emitidos e além da quantidade de gestos que cada indivíduo realiza simultaneamente (WALTERS et al., 2009; HENKEL, Z. et al., 2014). Isso pode influenciar diretamente no estabelecimento do ponto focal da interação.

Algo que pode ser feito para trabalhar mais próximo do ponto focal da interação é a aproximação entre os agentes, fazendo com que essa interação possua menos ruídos. Para que essa aproximação ocorra com sucesso, alguns fatores são importantes, como velocidade de aproximação, gestos e ruídos emitidos, entre outros fatores. Sendo assim, não é apenas o espaço social que a teoria de Proxemics se refere, mas também à análise comportamental dos agentes envolvidos na interação. Algumas variáveis que são utilizadas para a leitura corporal também são utilizadas na análise comportamental. Mead, Atrash e Maja J Matarić (2013) lista algumas variáveis consideradas em seu trabalho, além da distância social, são elas: (I) orientação da postura; (II) orientação do quadril; (III) orientação dos ombros; (IV) posicionamento e orientação da cabeça; e (V) fixação do olhar entre os indivíduos. Todas as variáveis apresentadas por Mead, Atrash e Maja J Matarić (2013) auxiliam a determinar a qualidade da interação social entre dois indivíduos ou entre robôs e humanos.

Proxemics tem sido explorado em trabalhos de interação humano-robô (IHR) desde 1997, e uma análise sobre a aplicação do tema é realizada por Z. Henkel et al. (2014), onde 
afirmam que este número continua em constante crescimento. Contudo, não é apenas em IHR que o tema de Proxemics é abordado. Trabalhos relacionados a tecnologia móvel e realidade virtual, também utilizam o tema com o intuito de melhorar a interação dos sistemas de maneira geral. Assim, a próxima seção apresentará os trabalhos relacionados que abordam o tema da Proxemics e tecnologias, seguido pela abordagem em IHR, sempre tentando demonstrar o vínculo dos trabalhos apresentados e a tese defendida neste texto.

\subsubsection{Proxemics na Interação}

Hemmert et al. (2013) apresentam um trabalho que tem como objetivo a aplicação de Proxemics em aparelhos de telefonia móvel. A ideia principal é fazer com que o telefone reaja de acordo com a aproximação do aparelho pela voz da pessoa. $\mathrm{O}$ foco principal dentre as oito variáveis de Proxemics é a postura do usuário. Interações de Proxemics tem sido um dos modelos gerais em interação humano-computador (IHC), onde a parte mais observada é o comportamento do usuário na interação com os diversos sistemas e dispositivos. Entretanto, é um tema pouco explorado em telefonia móvel (HEMMERT et al., 2013).

O projeto utilizado no caso de estudo apresenta uma nova maneira de interagir com dispositivos móveis, em especial telefones, tendo como base variáveis de linguagem corporal e proximidade do indivíduo para com o aparelho. Como trabalho futuro Hemmert et al. (2013) querem apresentar um modelo que faça a leitura de diversas variáveis com o intuito de entender por completo como elas funcionam no comportamento do ser humano.

Um ponto interessante abordado por Hemmert et al. (2013) é quando ele faz refêrencia ao uso de Proxemics em IHR. Diversos trabalhos sobre Proxemics aplicados a interação humano-robô (IHR) são apresentados ao longo dessa seção. Como o trabalho de Walters et al. (2009) que propõem um framework empírico com o objetivo de auxiliar a detecção da distância real, ou seja, a distância considerando fatores diversos da IHR.

Alguns fatores de impacto na IHR foram apresentados por Walters et al. (2009) na discussão de seu trabalho. Um dos fatores explorados foi o impacto dos sons emitidos pelo robô durante a interação, ou seja, a voz do robô. A voz não causa impacto apenas pelo volume que é emitida, mas também o estilo dela que pode influenciar uma vez que é possível inferir emoções a partir do estilo em que a voz é emitida. Além disso, a voz também pode influenciar no tempo de aproximação entre o robô e o indivíduo, pois dependendo de como o som é emitido pode gerar insegurança ao indivíduo que está interagindo com o robô (WALTERS et al., 2009).

Fatores como a aparência do robô e informações demográficas como idade, gênero, grau de instrução, personalidade, carisma, entre outros também podem interferir na IHR. Por exemplo, as pessoas preferem manter uma distância maior dos robôs que possuem uma aparência humanoide, pois ela causa um pouco de preocupação sobre as ações dele, quando comparado a um robô com aparência mais mecânica. Entretanto, a altura do robô não é um fator que apresenta grande relevância para IHR (WALTERS et al., 2009). 
Outro trabalho, apresentado por Torta et al. (2011), tem como objetivo a apresentação de uma arquitetura para robótica baseada em comportamento que permite ao robô navegar em segurança por um ambiente doméstico mutável e consiga codificar interações não verbais de maneira embarcada. Dessa maneira, é possível fazer com que o robô possa apresentar o comportamento de aproximação adequado ao seu objetivo, utilizando um modelo de espaço pessoal.

O modelo utilizado considera a relação entre a orientação do robô em conjunto com a distância do objetivo e a avaliação do indivíduo para orientar a aproximação do robô (TORTA et al., 2011). Para alcançar esse objetivo Torta et al. (2011) utilizaram um filtro Bayesiano para inferir a localização do objetivo a partir da posição do robô de maneira dinâmica. O filtro Bayesiano é utilizado como alimentação do algoritmo de navegação do robô. A trajetória e orientação do robô são ajustados para manter o em torno do usuário durante o processo de aproximação. É um ponto importante para pesquisas que trabalham com a proximidade entre robô e usuário em espaços sociais. Esse não é o ponto focal da tese apresentada ao longo desse texto, pois é realizado apenas um controle de dois agentes caminhando em um espaço em comum. $\mathrm{O}$ trabalho de Torta et al. (2011) não trata das reações do usuário e seus comportamentos durante a presença do robô próximo a ele.

Nos testes utilizou-se o robô NAO e obteve a validação de que a inclusão do espaço pessoal no algoritmo de navegação trouxe resultados positivos ao modelo implementado, pois o robô evitou de colidir e se aproximar do usuário de maneira muito próxima. Em estudos futuros, Torta et al. (2011) incluirão outros fatores ao cenário de IHR, como a altura do robô, a aparência e o propósito da interação, e a partir dessas novas variáveis identificar como é possível melhorar a interação de tal forma, que esse modelo obtenha uma qualidade maior em sua aplicação (TORTA et al., 2011).

A aplicação de Proxemics não é exclusiva a robótica social ou doméstica, Srinivasan, Z. Henkel e R. Murphy (2012) aplicam o conceito para o cenário de resgate de vítimas. O trabalho apresentado tem como objetivo avaliar a utilização do olhar social com movimentos de cabeça e funções escalares de Proxemics para auxiliar na aproximação e trabalho em regaste de vítimas em centros urbanos.

Nesse cenário o robô deve manter a vítima calma, tranquila, com pensamentos positivos e cuidar dela, na medida do possível, até que o resgate consiga acesso ao local para que o trabalho de extração seja realizado com sucesso. Dois cenários de simulação foram utilizados para validar o método proposto: no primeiro cenário observou-se como a vítima respondia a medida em que o robô gesticulava com a cabeça durante a interação comparado ao robô totalmente estático. O movimento da cabeça foi programado para ficar sincronizado com a fala do robô de tal forma, que seu comportamento ficasse próximo a um comportamento natural. Neste primeiro cenário, foi validado a hipótese de que o usuário prefere o robô que tem o movimento social (gesticulação da cabeça) ao invés do robô que permanece totalmente estático durante a interação (SRINIVASAN; HENKEL, Z.; MURPHY, R., 2012). 
No segundo cenário de simulação, utilizou-se funções escalares para definir a aproximação do robô junto à vítima. Nessa aproximação são consideradas as quatro regiões de proximidades, apresentadas na figura 1, para determinar a interação com a vítima. Foram comparadas três tipos de funções: (I) Logarítmica; (II) Linear; (III) Não escalar. Nos testes os melhores resultados foram obtidos através da função logarítmica, seguida pela função linear e depois a função não escalar (SRINIVASAN; HENKEL, Z.; MURPHY, R., 2012). A aproximação é realizada em uma situação extrema onde a pessoa sofreu um acidente devido a um desastre natural. Nessa situação a vítima está machucada e deitada no chão. As funções aplicadas realizam o controle dos motores do robô, que não são o foco desta tese. Porém, adicionar essas funções no robô podem corroborar para o sistema de navegação do robô em outros cenários. Dessa forma, Srinivasan, Z. Henkel e R. Murphy (2012) esperam melhorar a abordagem com robôs à vítimas de desastres em cenários de centros urbanos.

Okita, Ng-Thow-Hing e Sarvadevabhatla (2012) realizaram um estudo para identificar quais fatores mais auxiliam na redução da distância física entre o robô e o ser humano. Foram utilizados dois tipos de abordagem para os testes realizados: (I) Robô com a iniciativa de se aproximar do ser humano; e (II) Humano com a iniciativa de se aproximar do robô.

Para o teste de ambos cenários foram utilizados dois tipos de indivíduos, separados em dois grupos diferentes, crianças e adultos. Na execução do teste, Okita, Ng-Thow-Hing e Sarvadevabhatla (2012) utilizaram o método chamado de Wizard of Oz (WOZ) que permite operar o robô através de um controle remoto distante da vista do indivíduo em interação. Dessa forma, é possível passar a impressão de que o robô é autônomo e ao mesmo tempo ter o controle dele para que não ocorra nenhum acidente durante a interação.

O experimento foi executado de duas maneiras diferentes sendo uma o robô aproximarse sem nenhum tipo de aviso prévio e a outra maneira era exatamente avisar sua aproximação através de saudação via voz. Observou-se que quando o robô solicitava a permissão para aproximar do indivíduo o resultado sempre era positivo para a interação, quando comparado à aproximação sem aviso ou com aviso posterior a ação do robô (OKITA; NG-THOW-HING; SARVADEVABHATLA, 2012).

Muitos trabalhos apontam maneiras de aplicar o estudo de Proxemics em interações sociais. Algumas variáveis que podem afetar a interação são funções interpessoais de relacionamento, fatores fisiológicos moldados pela cultura de origem de um indivíduo, perspectivas etnológicas, além de informações sobre o ambiente de interação, como a luz ambiente, localização e ocupação física do agente, tamanho, entre outros fatores (MEAD; ATRASH; MATARIĆ, Maja J, 2011a).

Com a facilidade de compra dos sensores de captura de movimento não invasivo como o Microsoft $囚$ Kinect $($ ou o PrimeSensor $₫$, os pesquisadores Mead, Atrash e Maja J Matarić (2011a) apresentam em seu trabalho um conjunto de métricas que são capazes de auxiliar na automatização do processo de análise do comportamento para distância social. As métricas por 
eles estabelecidas são: postura, posição do quadril, do ombro, do torso, dos braços, distâncias entre os agentes, gênero, entre outros.

Com base nas métricas definidas foi realizado um estudo conceitual para verificar se o

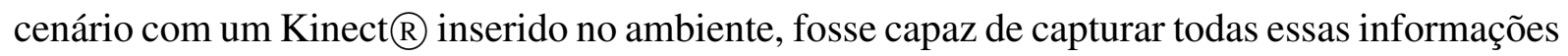
para que a partir delas, torna-se possível a criação de um mecanismo de análise automática do comportamento de agentes em um ambiente de interação social. Os testes preliminares possibilitaram a validação do cenário apresentado por Mead, Atrash e Maja J Matarić (2011a).

Um cenário e ferramenta para coleta de informações sobre indivíduos em interação social são apresentados também por Mead, Atrash e Maja J Matarić (2011b). O principal objetivo é utilizar as informações coletadas em estudos futuros. Essas informações serviram para a criação de um modelo oculto de Markov (Hidden Markov Model (HMM), em inglês) com seis classes para auxiliar na predição das Proxemics de interação face a face. Nesse estudo, o HMM demonstrou-se com um desempenho superior para a tarefa de predição, quando comparado com um classificador aleatório ponderado por pesos (MEAD; ATRASH; MATARIĆ, Maja J, 2011b).

Em um trabalho posterior, Mead, Atrash e Maja J Matarić (2012) apresentam uma discussão sobre os tipos de representações de variáveis para Proxemics. Essas representações são: física e psicológica. Além desses dois tipos é proposto uma representação psicofísica que apresenta uma abordagem permitindo unir melhor as qualidades dos outros dois tipos de representação. A representação física tem como objetivo analisar como o espaço social é ocupado por dois indivíduos e é a abordagem mais comum em estudos de Proxemics, tanto para interações humano-humano quanto para interações humano-robô. A representação psicológica mantém o foco em fatores de relacionamento interpessoal de alto nível entre dois ou mais indivíduos. Esse fatores estão relacionados a teoria de conflito afiliativo (ARGYLE; DEAN, 1965) e também a teoria de adaptação interpessoal (BURGOON; STERN; DILLMAN, 2007).

Porém, com as lacunas existentes nesses dois tipos de representação de Proxemics, foi proposto o tipo psicofísico. Os tipos psicofísicos têm como objetivo principal analisar a percepção e a produção de estímulo social entre dois ou mais indivíduos interagindo. A abordagem psicofísica é discutida também por Hall (1969). Essa representação está diretamente ligada com a experiência sensorial do estímulo social até os parâmetros espaciais de maneira física. A partir da representação psicofísica é realizado um estudo para capturar informações que servirão de base para treinamento de dois HMM. Cada HMM é responsável por uma exclusiva tarefa, início da interação ou término da interação. Essa representação deve auxiliar nas pesquisas de interação humano-robô, no intuito de que seja possível realizar uma análise para a interação ocorrer com maior qualidade (MEAD; ATRASH; MATARIĆ, Maja J, 2012).

Outro trabalho de Mead e Maja J Matarić (2012) apresenta um mecanismo de análise comportamental através da Proxemics. Utiliza-se modelos probabilísticos de tal forma, que seja possível determinar alguns comportamentos dos indivíduos durante uma interação. Como métrica de proximidade utilizou-se a estratégia do mundo de grades para predizer a distância aproximada entre o robô e o indivíduo. O objetivo final do teste realizado no trabalho é fazer 
com que o robô consiga se posicionar frente a frente com o ser humano. A partir do posicionamento fica possível iniciar uma interação entre humano e robô. Esse trabalho é implementado através de uma rede Bayesiana dinâmica como uma evolução para o mecanismo apresentado em trabalhos anteriores (MEAD; MATARIĆ, Maja J, 2012).

Conforme tem sido discutido ao longo dessa seção, para que a interação entre um humano e um robô possa ocorrer de maneira confortável e com qualidade, ou seja atendendo as normas sociais, é necessário que o robô entenda as variáveis de espaço social. Além disso, é necessário também que ele possua o controle sobre essas variáveis de tal forma, que ele consiga tomar decisões sobre as ações que executará (MEAD; MATARIĆ, Maja J, 2013).

Mead e Maja J Matarić (2013) apresentam um estudo baseado principalmente com variáveis de voz e gestos, utilizando um método de amostragem que tem como entrada a postura do indivíduo ao interagir com o robô, em outras palavras, a orientação do corpo representando assim uma linguagem corporal. A maior contribuição esperada por Mead e Maja J Matarić (2013) é a apresentação do entendimento obtido através das interações pré culturais que estão inseridas junto ao estudo de Proxemics. O resultado apresentado é apenas uma base de dados para investigar todos os aspectos da interação humano-robô apresentadas no trabalho (voz e gestos).

A partir da base de dados gerada por Mead e Maja J Matarić (2013), é apresentado outro trabalho onde Mead, Atrash e Maja J Matarić (2013) discutem a utilização de um HMM para extração de características comportamentais espaciais do ser humano (apresentadas na tabela 1), em outras palavras, Proxemics. Alguns fabricantes de sensores de movimentos, como

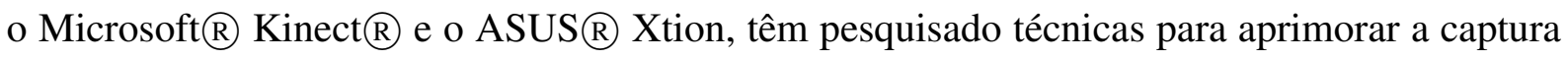
de informações sobre usuários, assim os equipamentos podem ser utilizados em estudos de interação com seres humanos.

Com base nesses estudos, Mead, Atrash e Maja J Matarić (2013) analisam a possibilidade de automatizar o processo de análise das Proxemics. A intenção do trabalho é extrair variáveis (vide tabela 1) para que seja, então, possível determinar o início da interação, dado pela aproximação em direção do indivíduo, e o fim da interação social, que é o chamado de fuga social ou o afastamento para uma zona social mais pública sem intenção de uma reaproximação, através de um HMM. As variáveis apresentadas na tabela 1 são analisadas para compor as variáveis da seção 4.1.2.2 apresentada nessa tese.

Para realizar os experimentos de Mead, Atrash e Maja J Matarić (2013), foram necessários dois indivíduos e um robô aplicados a um cenário de interação, onde os indivíduos se aproximam do robô sendo que os indíviduos estão separados por uma parede. Os resultados são apresentados em relação ao ponto de vista físico e psicológico. Na detecção das variáveis que representam as Proxemics de maneira dinâmica, Mead, Atrash e Maja J Matarić (2013) consideram os resultados satisfatórios e como sequência do trabalho é investigar interações com fatores psicológicos complexos como foco principal. 
Tabela 1 - Variáveis Comportamentais apresentadas por Mead e Maja J Matarić (2013)

\begin{tabular}{c|l}
\hline \multicolumn{2}{c}{ Características Individuais } \\
\hline Stance Pose & Orientação da postura do corpo \\
\hline Hip Pose & Orientação do quadril \\
\hline Shoulder Pose & Orientação do tronco \\
\hline Head Pose & Orientação dos ombros \\
\hline Hip Torque & Orientação da cabeça \\
\hline Shoulder Torque & Torção do quadril \\
\hline Head Torque & Torção dos ombros \\
\hline \multicolumn{2}{c}{ Características Físicas } \\
\hline Distância Total & Calculada com base na distância euclidiana en- \\
\hline Straight-Ahead Distance & tre os dois agentes \\
\hline Distância Lateral & Magnitude no eixo X \\
\hline Orientação Relativa do Corpo & Magnitude no eixo Y \\
\hline \multicolumn{2}{c}{ Características Psicofísicas } \\
\hline Distance Code & Variável baseada na distância total \\
\hline Socialfugal-SocioPetal Axis Code & Variável baseada na orientação do corpo \\
\hline Visual Code & Variável baseada na posição da cabeça \\
\hline Voice Loudness Code & Variável baseada na distância total \\
\hline Kinesthetic Code & Variável baseada na distância entre a posição do \\
\hline Olfaction Code & quadril, tronco, ombros e braços \\
\hline Thermal Code & Variável baseada na distância total \\
\hline Tode & Variável baseada na distância total \\
\hline Aariável baseada na distância total \\
\hline
\end{tabular}

Fonte:Adaptado de Mead e Maja J Matarić (2013).

Mead e Maja J Matarić (2014) direcionam o foco de seu trabalho para a análise de conversa social e gestos, tanto na questão de produção das conversas e gestos de maneira automática quanto para o reconhecimento, aplicados em interações humano-humano e humano-robô. Todo o trabalho realizado está relacionado com o estudo de Proxemics na interações sociais, uma vez que essas têm o objetivo de não só identificar as variáveis (vide tabela 1), mas também de interpretar, manipular e compreender a dinâmica do comportamento espacial dentro do cenário das interações sociais.

Os estudos e experimentos sociais realizados por Mead e Maja J Matarić (2014) auxiliaram na coleta de informações sobre o volume da fala de acordo com a distância, medida em polegadas, além dos gestos que necessitam de espaços maiores para execução sem prejudicar a interação. Os resultados apresentados apontam que a distância de interações entre humanos é menor que a distância da interação entre um humano e um robô. Além disso, os resultados obtidos não são aplicados à múltiplas culturas (nesse caso origem dos indivíduos), e isso deve ser realizado em outros trabalhos segundo Mead e Maja J Matarić (2014). Um mecanismo para 
personalizar o tratamento que o robô terá com o indivíduo durante a interação também é algo que deve ser construído ao longo dos trabalhos futuros.

Duas bibliotecas que colaboram para a execução de trabalhos com interação humano e robô, focadas em robótica assistiva e social, são apresentadas por Mead et al. (2014). Essas bibliotecas são compostas por uma sequência de trabalhos que estão em construção e mantémse privadas até sua conclusão. A primeira biblioteca é chamada de Social Behavior Library (SBL) que tem o objetivo de prover os controles adequados para o robô saber como executar uma tarefa. Ela trata as questões do comportamento social do robô, como por exemplo, saber respeitar o espaço de uma pessoa. A segunda é a Social Interaction Manager (SIM) que está focada em tomadas de decisão no mundo real. As técnicas aplicadas são para resolver problemas de reconhecimento, tomada de decisão e aprendizado, ou seja, informa ao robô o que ele deve fazer em uma determinada situação.

Um framework para trabalhar com proximidade entre humano e robô, é apresentado por Mead e Maja J. Matarić (2016). O processo proposto é dividido em três etapas, que compõe este framework. A primeira etapa é a estimativa das ações para se aproximar e ficar com o robô frente a frente com o ser humano, pois é afirmado pelos autores que a melhor maneira de promover uma interação é posicionando os agentes olhando de frente um para o outro. Para realizar essa estimativa foi criada uma rede Bayesiana que considera a posição relativa entre humano e robô, altura do som emitido pelo ser humano e o percebido pelo robô, e também os gestos emitidos e percebidos em cada zona de proximidade. Depois de estimar a posição final o robô realiza cálculos para determinar a distância que será percorrida, e também as diferenças entre os ângulos referentes a orientação do robô para pessoa e da pessoa para o robô. Isso resulta na diferença entre orientação atual para orientação objetivo. Como passo final, o robô realiza o planejamento de trajetória global que é ajustado ao longo do caminho considerando não só o ambiente ao redor, mas também o rastreamento dos movimentos da pessoa que ele está em busca da interação, já que é considerado que a pessoa está em constante movimento. Esse procedimento melhorou o encontro face a face, entre seres humanos e robôs.

Definir um conjunto de variáveis para estudos com interação humano-robô é o foco do trabalho apresentado por Joosse, Sardar e Evers (2011). O conjunto de variáveis apresentados tem o objetivo de avaliar as respostas humanas durante a interação. O primeiro conjunto de variáveis apresentados, correspondem a medidas para atitudes pessoais:

a) Aparência do robô com o humano: o quão próximo de um ser humano o robô é. Essa é uma medida feita através de uma escala Likert de sete pontos, com tópicos como "Human-made - Humanlike" ou "sem gênero - masculino ou feminino".

b) Atitudes em relação ao robô: refere-se a atitudes negativas que o robô pode gerar socialmente. Também é medido através de uma escala Likert de 7 pontos.

c) Confiança no robô: refere-se a confiança da pessoa no robô que interage com ela. Escala Likert de 7 pontos com credibilidade de fonte. 
d) Aparente habilidade social do robô: para medir as habilidades é utilizado uma escala likert de 5 itens chamada Wish \& Kaplan. Esse método originalmente possui uma escala bipolar de 9 pontos, porém foi revertida em uma escala Likert de 7 pontos.

e) Atração física e social do robô: inclui-se itens de escala de atração interpessoal, que originalmente possuem uma escala de Likert 7 pontos com 15 itens. Porém foi realizado uma adaptação com a exclusão de 5 itens, mantendo apenas 10 itens que representam as atrações físicas e sociais.

Além da lista sobre atitudes pessoais, Joosse, Sardar e Evers (2011) apresentam medidas comportamentais que são preenchidas pelo especialista através da observação do vídeo feito durante o teste. Nas medidas comportamentais ele deve marcar se houve repostas de linguagem corporal como se afastar do robô ou se houve uma inclinação em direção ao robô. Também são inclusas expressões faciais como sorrindo ou se parecia assustado.

Para validar a proposta de Joosse, Sardar e Evers (2011) foi utilizado um cenário, onde o ser humano fica parado em frente a alguns quadros, observando-os, e após um certo período de tempo o robô se aproxima com uma determinada velocidade. Um vídeo é gravado com todo o processo do teste. Após o processo de teste concluído, os vídeos são analisados e o questionário criado é preenchido e depois quantificado para realizar a análise estatística.

Durante as análises realizadas percebeu-se que as habilidades sociais não interferiam nas reações do ser humano durante a interação. Dessa maneira, todos os pontos sobre habilidades sociais foram removidos do questionário. Apesar de terem removido os pontos sobre habilidades sociais do robô, Joosse, Sardar e Evers (2011) acreditam que é um ponto importante e deve ser investigado com mais calma, pois pode apresentar resultados importantes para o processo de interação.

A questão de reconhecimento de expressão facial e características faciais de movimento podem ser úteis no futuro para ajuda na avaliação das emoções das pessoas. Joosse, Sardar e Evers (2011) esperam que este arcabouço de questões, seja utilizado em mais pesquisas para tentar fazer com que ele torne-se mais robusto.

Analisando a diferença de cultura para variáveis de Proxemics, Eresha et al. (2013) apresentam como objetivo do trabalho a avaliação do comportamento de indivíduos ao se encontrarem com dois robôs interagindo entre si e caminhando em direção ao indivíduo de tal forma que este possa também interagir ou não com os robôs conforme a aproximação do ser humano. Além de avaliar o comportamento dos indivíduos durante a interação com os robôs, Eresha et al. (2013) adicionaram a variável de cultura ao estudo. O objetivo é identificar como é a diferença de comportamento entre culturas diferentes. Foram escolhidos participantes de origem árabe e alemã para o estudo.

Nos experimentos, Eresha et al. (2013) utilizaram dois robôs NAO que se posicionavam a $40 \mathrm{~cm}$ de distância entre eles e caminhavam até ficarem a uma distância diagonal de $85 \mathrm{~cm}$ do indivíduo. Para o experimento houve a participação de 24 indivíduos, 12 árabes e 12 alemães, 
sendo metade do gênero feminino e a outra metade do gênero masculino. Os testes apresentaram resultados interessantes, pois alguns indivíduos não reagiram como o esperado para pessoas de sua origem e muitas vezes o comportamento social na interação era idêntico entre alemães e árabes. Outro ponto apresentado por Eresha et al. (2013) é que durante os testes dois alemães apresentaram o sentimento de medo de serem atacados fisicamente pelos robôs.

O trabalho de Eresha et al. (2013) apresenta indícios de que as variáveis de Proxemics não estão ligadas a cultura do indivíduo, como origem, mas sim na experiência cultural que este teve ao longo de sua vida. Dessa maneira, pode-se dizer que Proxemics são variáveis extraculturais, porém é necessário realizar um tratamento para esse tipo de condição verificando a origem do indivíduo, onde o robô possa interagir com mais qualidade com pessoas que possuem diferentes experiências culturais.

Zachary Henkel et al. (2012) investigam características entre diversas plataformas de teste para interação humano-robô, e com base no resultado deste estudo é realizado a proposta de uma nova plataforma de testes. A nova plataforma foi desenvolvida, pois Zachary Henkel et al. (2012) alegam que não existe nenhuma plataforma de teste capaz de atender aos seis atributos de dependência das Proxemics. Os atributos são: (I) movimento afetivo; (II) leitura das Proxemics; (III) interação de voz; (IV) manipulação do estilo de áudio; (V) controle do olhar; e (VI) apresentação de conteúdo através de mídia, por exemplo, monitor ou leds.

A plataforma é constituída por uma cabeça feita com um monitor de 7", junto com um encaixe construído para ser acoplado em qualquer base de robôs já existentes no mercado. Alguns testes que foram realizados no cenário de resgate à vítimas, demonstram que as pessoas que tinham a zona de espaço social íntimo invadida por qualquer parte do robô, sem uma interação prévia, ficavam em situação de stress elevado. Essa reação foi totalmente oposta quando o robô iniciava com qualquer tipo de interação antes de realizar a aproximação do indivíduo (HENKEL, Zachary et al., 2012). O primeiro contato antes da aproximação para uma interação maior é importante, pois esse comportamento pode definir o quão confortável a interação entre os agentes será e esse comportamento deve ser explorado durante a execução dessa tese.

Em outro trabalho, Z. Henkel et al. (2014) apresentam duas funções escalares para avaliar os valores de proximidade entre humanos e robôs. As funções escalares são comparadas com outras funções não-escalares e também entre si de tal forma, que seja possível uma tomada de decisão em tempo de execução da ação/interação. As duas funções escalares apresentadas são: (I) logarítmica; e (II) linear.

Os testes foram executados no cenário de regaste à vitimas. Quando a função logarítmica foi aplicada, os resultados apresentados foram melhores do que os obtidos com as demais funções. Como o principal objetivo de Z. Henkel et al. (2014) é generalizar o método para outros cenários, eles pretendem realizar testes do modelo em outras situações e também utilizando outros tipos de robôs para sustentar melhor a hipótese. Os estudos prévios realizados demonstram que a generalização do modelo é possível. 
A integração social do robô com os ambientes que envolvem cenários de cuidados médicos, construção, educação, serviço públicos, entre outros pode ser a chave de sua aceitação por parte dos seres humanos. Um dos caminhos para conseguir esse objetivo é fazer com que o robô saiba ter um comportamento adequado de interação em cada um desses cenários, assim como o que já é demonstrado em filmes de ficção científica. Dessa maneira, é possível fazer com que os seres humanos utilizem o próprio senso social para identificar essas habilidades no robô, quebrando um pouco o medo de interagir com ele (HEENAN et al., 2014).

Como primeiro passo para que a interação ocorra naturalmente entre o ser humano e o robô, Heenan et al. (2014) acreditam que deve haver sempre uma saudação entre ambas partes logo ao primeiro contato. Esse tipo de comportamento pode ser fundamental para que haja uma aceitação social do robô entre as pessoas. Durante uma saudação existem diversos fatores que são analisados implicitamente pelo ser humano, como gradações de comunicação não verbal, vocalização das palavras e a distância interpessoal. Esses fatores devem ser considerados ao projetar uma saudação por parte do robô, fazendo com que seja possível o robô iniciar a interação.

Fazer com que um robô realize uma saudação natural não é uma tarefa muito fácil. Deve ser considerado que um robô não tem a mesma capacidade de identificar as gradações sociais com a mesma velocidade de um ser humano. Outro ponto negativo é que o robô possui o lado mecânico limitado, quando comparado a musculatura do ser humano. Assim, o primeiro objetivo do trabalho de Heenan et al. (2014) é definir um subconjunto exato de elementos de uma saudação social que possa ser articulado pelo robô durante a tarefa e ainda como implementar as sutilezas do comportamento da interação de saudação social.

Os testes executados demonstram que a saudação é um ponto importante para o resultado com sucesso da interação com o ser humano. O robô NAO utilizado nos testes foi capaz de implementar ações de comportamento como o contato visual, linguagem corporal e distância social para comunicação efetiva. Apesar de algumas restrições do modelo de saudação ocorrerem devido a limitação do NAO, é possível realizar a generalização do mesmo para outros robôs (HEENAN et al., 2014).

Percebeu-se que o contato visual se apresentou como um elemento de interação social bem natural, contudo deve-se tomar cuidado para que o robô não fique encarando a pessoa constantemente, pois é gerado um desconforto para a pessoa durante o contato. Heenan et al. (2014) dizem que é possível afirmar que utilizar a saudação é importante no primeiro contato de dois agentes, além de aumentar a capacidade da interação social entre o robô e o ser humano.

Vázquez et al. (2014) apresentam um robô móvel no formato de mobília, chamado Chester, construído para realizar interações com crianças. Como o Chester é muito grande optou-se por usar um segundo robô não móvel, ao qual Vázquez et al. (2014) denominam sidekick. O sidekick é como um parceiro ou personagem secundário que auxilia as pessoas em volta a prestarem atenção no personagem principal, como por exemplo o burro da animação Shrek. O 
sidekick criado é um abajur chamado Blink. Ele fica acoplado em cima do Chester. A figura 2 apresenta a combinação dos robôs Chester e Blink.

Figura 2 - Os robôs Chester e Blink.

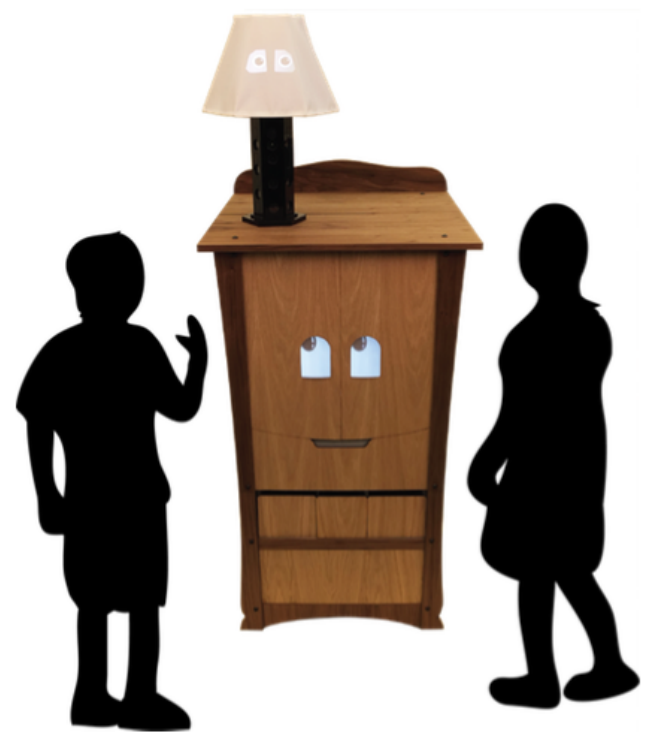

Fonte: Vázquez et al. (2014).

Blink tem uma linguagem própria e apenas o Chester é capaz de entender. É como o R2D2 em Star Wars que apenas alguns personagens são capazes de compreende-lo e falar com ele diretamente. Os resultados obtidos mostram que a inserção de um sidekick não altera a questão de proximidade das crianças em relação ao robô, mas melhora a atenção com os elementos falantes do cenário (VÁZQUEZ et al., 2014).

Foi possível caracterizar alguns comportamentos das crianças ao interagir com os robôs. É afirmado por Vázquez et al. (2014) que o formato de mobília para robôs é plausível para utilizar em robôs que interagem com crianças, pois elas se sentem mais empáticas aos robôs. Contudo, é questionável essa afirmação. Será que o que realmente influenciou esse resultado foi o formato do robô ou foi seu comportamento durante o contato com as crianças? Provavelmente, esse é um resultado que pode ser obtido com a mistura desses dois fatores, aparência e comportamento. Assim como apresentado por Joosse, Sardar e Evers (2011), a aparência do robô pode auxiliar na interação e principalmente na expectativa de comportamento do robô durante a execução da tarefa e interação.

Por questões de segurança os testes foram executados utilizando o método Wizard of $\mathrm{Oz}$ (WoZ), onde existe um especialista controlando o robô através de um controle de videogame, por exemplo, dando a sensação de robô completamente autônomo. Foram conduzidos duas variantes do teste, são elas: (I) com o sidekick ativo; e (II) com o sidekick inativo. O especialista que controla o robô encontrava-se na mesma sala de teste, mas algumas precauções foram consideradas para que não houvesse ruído nos resultados do teste. Uma dessas precauções foi inseri-lo na sala do teste antes de iniciar o teste, assim aparenta que o especialista estava 
apenas trabalhando na sala. Além disso, o controle do robô foi posicionado embaixo da mesa para facilitar a oclusão do objeto e ainda fez com que nenhuma criança notasse que o robô era teleoperado por um especialista (VÁZQUEZ et al., 2014).

Para capturar as informações de distância foi acoplado ao teto um sensor Microsoft Kinect. Ele é responsável por capturar as informações de distância entre o robô e a criança interagindo com ele. Notou-se que na maioria das vezes a criança ficava sempre de frente a face do robô e não ao seu lado ou atrás dele. Variáveis como o tempo de resposta para se afastar enquanto o robô dizia "recue" também foi considerado para identificar os resultados (VÁZQUEZ et al., 2014).

Nos resultados finais, Vázquez et al. (2014) encontraram algumas limitações do robô e também do experimento, como por exemplo, o pouco conteúdo de linguagem que o robô possui implementado para dar respostas aos participantes do teste. Outro problema encontrado foi no início e final da interação, onde pontos do cenário atrapalharam a coleta de informações, comprometendo o foco do caso de estudo. Devido a esse problema, a utilização de um sidekick deverá ser estuda com mais detalhes e realizar os testes novamente para que possa ser comprovado o real benefício dele nos resultados da interação. Resultados preliminares confirmam que o sidekick não atrapalha na interação, entre o robô principal e as pessoas. Ele auxilia no aumento da atenção das pessoas, o que resulta em um comportamento reativo melhor dos participantes (VÁZQUEZ et al., 2014).

Alguns estudos utilizando robôs para interagir com crianças com autismo apontam que pode apresentar reações positivas e negativas para o âmbito social. Especialistas são capazes de identificar esse tipo de avaliação através da análise dos vídeos gravados entre sessões. $\mathrm{O}$ objetivo do trabalho de Feil-Seifer e Maja Matarić (2010) é automatizar esse processo de análise através do uso de robôs. Para isso foi desenvolvido um classificador heurístico que utiliza um conhecimento prévio para auxiliar à discretizar as crianças que conseguem interagir com o robô daquelas que não conseguem.

O cenário de teste é composto de uma sala, um robô totalmente autônomo com o objetivo de incentivar a interação, uma criança diagnosticada com autismo e um familiar mais próximo. Para incentivar a interação, o robô deve se aproximar apresentando vocalizações de sons felizes e também esboçar um sorriso para a criança, por exemplo. Caso alguma criança se afaste do robô, ele deve esboçar uma face triste e emitir sons que demonstre a sua não felicidade (FEILSEIFER; MATARIĆ, M., 2010).

Durante os testes foram gravados vídeos e algumas marcações foram realizadas no robô, e nos pais, com o intuito de auxiliar na medida das distâncias entre a criança e o robô ou seus pais. Para realizar uma avaliação sobre esse cenário foi utilizada a seguinte heurística: Para cada trecho de tempo se a criança encontrar-se a 0,85 m dos pais, ela é considerada próxima à eles. Caso ela encontra-se a 0,5 m de uma parede, ela é considerada próxima a parede. Para ser considerada atrás do robô, ela deveria estar a qualquer distância, mas entre uma angulação maior que $135^{\circ}$ e menor que $-135^{\circ}$ (FEIL-SEIFER; MATARIĆ, M., 2010). 
A partir das informações capturadas é possível gerar o classificador onde ele análise se pelo menos $50 \%$ do tempo gasto é com as informações de comportamento negativo (mapeado pelas heurísticas), então é considerado que a criança não deseja interagir com o robô. Caso contrário, menos de $50 \%$ do tempo gasto, a criança deseja interagir com o robô. Apesar dos resultados positivos, esse classificador não deve ser considerado como regra para que haja uma maior escalabilidade do projeto e sua aplicação (FEIL-SEIFER; MATARIĆ, M., 2010). Esses tipos de parâmetros podem auxiliar na determinação de interação ou não interação. Dessa forma, pode-se fazer com que o robô recue ou tente uma nova abordagem, para quando a reação do indivíduo for negativa.

Outros estudos confirmam a existência de uma relação de distância social entre o robô e o ser humano, entretanto nenhum método foi proposto computacionalmente para que haja uma geração do comportamento em relação a essa distância (HENKEL, Zachary; MURPHY, R. R.; BETHEL, 2012). Assim, é apresentado um método escalar do comportamento do robô tem-se base na distância social utilizando como suporte uma lei física e duas psicofísicas, que trabalham com a magnitude da percepção sobre os fatores físicos do ambiente. São elas: inversesquare law, Weber-Fechner law e Steven's Power law (HENKEL, Zachary; MURPHY, R. R.; BETHEL, 2012). O cenário de teste é um ambiente de desastre no qual o robô deve localizar a vítima. A interação ocorre por meio de voz sintetizada, caminhos pre definidos e controle segundo o módulo de teste WoZ. Como meio de avaliação questionários pré e pós interação são aplicados aos usuários que participam do teste (HENKEL, Zachary; MURPHY, R. R.; BETHEL, 2012).

Atributos primários foram determinados para que possam ser identificados alguns níveis de consistências sociais: conforto, movimentos naturais, consideração do espaço pessoal, segurança e controle próprio. Atributos secundários também foram considerados nos estudos de Zachary Henkel, Robin R. Murphy e Bethel (2012), são eles: atenção, empatia, felicidade, similaridade, inteligência, sensibilidade, submissão e confiança. Os resultados demonstram que todos atributos primários (conforto, movimentos naturais, consideração do espaço pessoal, segurança e controle próprio) e apenas três secundários (inteligência, empatia e submissão) provaram que apresentam melhor significância para o processo. Isso ocorreu onde o sistema de percepção escalar, provou ser melhor do que o não escalar. O modelo escalar linear apresentou o mesmo resultado que o não escalar (HENKEL, Zachary; MURPHY, R. R.; BETHEL, 2012). Esse é um resultado importante, pois a função de aproximação do robô para a pessoa deve ser ajustada conforme a distância diminui. Nessa tese observou-se durante os testes que o robô ao se aproximar de maneira brusca, gerou um desconforto e um pouco de medo em alguns usuários. Comportamento diferente de quando o robô se aproximou de maneira mais suave.

Andrew G. Brooks e Ronald C. Arkin (2007) apresentam um modelo comportamental em camadas para auxiliar no processo de comunicação não verbal do robô com o ser humano. Um comportamento em camadas é definido como um processamento de saída a nível dos motores (atuadores) do robô, onde é realizado uma sequência de passos para deixar o movimento do 
robô mais natural ao do ser humano. Neste trabalho é discutido uma generalização do modelo para que seja possível aplicar em diversas plataformas robóticas e fontes de informação.

No trabalho é explorado a questão de linguagem corporal, pois expressões faciais já são amplamente utilizadas para estudos de interação humano e robô. Andrew G. Brooks e Ronald C. Arkin (2007) apresenta a implementação funcional de seu modelo em um robô Sony QRIO. Alguns dos resultados apresentados são que o tamanho do robô pode influenciar no tipo de interação que ocorrerá, que a utilização da teoria de proximidade é essencial para que ocorra uma boa interação, e que comunicações não verbais são a principal forma de comunicação em uma interação humano e robô.

Um dos pontos chave dos trabalhos apresentados ao longo dessa seção é que sempre utilizam sensores no ambiente para medir as variáveis de proximidade entre a pessoa e o robô. Contudo, o uso de sensores extra robô espalhados no ambiente torna o processo não natural quando trata-se de robô móvel, uma vez que seres humanos não interagem com base em visões de outros pontos do ambiente. As variáveis de proximidade se mostram essenciais para determinar o sucesso de uma interação ou não, e devem ser consideradas ao longo da proposta desta tese de doutorado.

Durante a revisão da literatura apresentada neste capítulo, observou-se que os trabalhos em IHR tem foco principalmente nas aplicações e comportamentos do robô. Poucos trabalhos consideram informações sobre a pessoa e sobre a experiência de interagir com o robô. Outro aspecto identificado é a inexistência de pesquisas que englobam uma abordagem sistêmica para o processo de construção do robô considerando interação humano-robô. Esses são pontos importantes, que podem garantir a aceitação dos robôs em ambientes sociais presentes no dia-a-dia das pessoas. O próximo passo, é a definição dos conceitos de experiência de usuário que podem colaborar na construção de robôs aceitos pelos usuários. Na sequência determinar os pontos para construção de um projeto de interação humano-robô, que possa ser atualizado conforme a evolução do robô. 


\section{EXPERIÊNCIA DE USUÁRIO}

Novos sistemas computacionais e maneiras de interação, como em internet das coisas, realidade virtual e aumentada, celulares inteligentes, robôs, entre outros, fazem com que especialistas fiquem empolgados e utilizem processos para criar e refinar as aplicações básicas que são apresentadas no mercado ao longo do tempo (HARTSON; PYLA, 2012). Robôs são sistemas ativos em cenários encontrados nas tarefas do dia-a-dias, que possuem uma capacidade de interagir diretamente com o usuário.

Dessa maneira, pode-se dizer que sistemas computacionais vão além de computadores de mesa ou notebooks, além de interface gráfica com usuário, seja em sistemas locais ou executados em servidores na nuvem e web. Cada vez mais sistemas computacionais tornam-se ubíquos, ou seja, difundido entre os produtos mais inesperados do mercado, sendo peças de roupas ou eletrodomésticos (HARTSON; PYLA, 2012).

Ao desenvolver um produto voltado para seres humanos, este produto necessariamente terá um usuário. Então toda vez que esse produto for utilizado, ele proverá uma experiência para a pessoa que o usou (GARRETT, 2010).

Essa experiência vivida, a experiência do usuário, é definida como a experiência criada por um produto em pessoas que fazem seu uso no dia-a-dia dentro do mundo real. Ela é parte de uma equação de "como isso funciona", geralmente em um pedaço que não tem muita atenção no projeto mas, é essencial para determinar o sucesso ou a falha no lançamento deste produto (GARRETT, 2010).

Experiência de usuário refere-se em como o produto funciona fora do laboratório, quando pessoas em situações reais entram em contato com ele diariamente. Observando o assunto, de uma certa maneira todos os produtos existentes e disponíveis para consumo geram uma experiência de usuário, de garrafas de ketchup à suéteres, de livros a computadores, e quaisquer outros produtos que possam imaginar (GARRETT, 2010; ALBERT; TULLIS, 2013).

Um produto desenvolvido para prover boa experiência de usuário, vai além de funcionalidades e aparência estética. Desenvolver um produto corretamente refere-se a questões psicológicas e comportamentais com os próprios usuários durante o uso. Quanto mais complexo for um produto, maior a dificuldade de entregar uma experiência adequada ao usuário (GARRETT, 2010; ALLEN; CHUDLEY, 2012).

A maneira mais eficiente de prover experiência de usuário correta em um produto, é utilizando o projeto centrado no usuário. Esse tipo de projeto considera o usuário durante todas suas etapas, guiando o produto para resultados surpreendentes apesar de mais complexos para análise (GARRETT, 2010; ALLEN; CHUDLEY, 2012; ALBERT; TULLIS, 2013).

Garantir uma boa experiência de usuário pode ser realizado através do conceito de usabilidade, presente nos conceitos de interação humano-computador (IHC). Uma interação entre humano e computador ocorre quando um usuário (humano) e um sistema (computador) tra- 
balham juntos com o objetivo de realizar algo em comum (ANDERSON, 2011; HARTSON; PYLA, 2012).

A usabilidade é um conceito que tem como objetivo principal garantir a interação com efetividade, eficiência e satisfação para o usuário. A ISO 9241-11 de 1997, define algumas características para usabilidade: (I) Fácil de usar; (II) Produtividade; (III) Eficiência; (IV) Efetividade; (V) Fácil aprendizado; (VI) Retenção de conhecimento; e (VII) Satisfação do usuário (HARTSON; PYLA, 2012).

Um produto que entrega uma experiência de usuário adequada, é mais importante do que um produto que possui muitas funcionalidades, um exemplo apresentado por Hartson e Pyla (2012) é o do Blackberry que comparado ao iPhone possui muito mais funcionalidades, porém a experiência entregue de maneira inadequada fez com que ele fosse desbancado pelo último no mercado. A experiência pela interação é o sistema em si, no ponto de vista do usuário.

A experiência de usuário possui o seguinte escopo (HARTSON; PYLA, 2012):

a) efeitos com base nos fatores de usabilidade;

b) efeitos com base nos fatores de utilidade;

c) efeitos com base nos fatores de impacto emocional.

Dentro dos fatores que afetam os efeitos da experiência de usuário, pode-se listar pelo menos 5 (cinco) qualidades diferentes que impactarão a experiência de um usuário ao interagir com um determinado sistema (HARTSON; PYLA, 2012):

a) Utilidade: talvez a mais fundamental das qualidades. Está ligada ao conceito do que serve o sistema. Se é importante para o usuário ou o quão interessante é o conteúdo exposto no sistema. Lembrando que um conteúdo poder ser interessante para um usuário, mas não para o outro. Um determinado produto pode atingir múltiplos de maneira diferente, de acordo com o interesse de cada um. É importante conhecer e manter sólido esse conhecimento sobre o público principal do produto.

b) Integridade Funcional: é a qualidade de manter o sistema funcionando, como ele deve funcionar. A falta de integridade funcional resulta em um produto com muitos erros. Sua falta pode ser comparada a um vírus no código do sistema.

c) Usabilidade: refere-se ao quanto é fácil de aprender a usar, quando trata-se de usuários de primeira viagem e esporádicos, e o quanto é fácil de usar, tratando-se de usuários frequentes ao uso do sistema. Um produto pode atender as questões de utilidade e integridade funcional, porém o seu uso pode ser difícil e ainda apresentar tédio para o usuário.

d) Persuasividade: é quando o produto consegue, em um determinado nível, incentivar o seu uso, manter uma conversa com o usuário para que ele sinta-se atraído, além de direcionar comportamentos específicos durante seu contato.

e) Aparência (Design Gráfico): são as cores, tipografias e todos os elementos referentes a aparência do produto onde é possível gerar um grande impacto na expe- 
riência do usuário. Todos os elementos geram impactos emocionais nos usuários do sistema e podem fazer total diferença na hora dele optar por continuar ou não o uso.

Todas essas qualidades de experiência de usuário contribuem entre si, porém considerálas de maneira separada auxilia na aplicação efetiva durante o projeto do produto, sendo este um web site, uma caixa de presente ou até mesmo um robô social de serviço doméstico.

Alguns especialistas definem experiência de usuário como uma sequência de efeitos sentidos pelo usuário, em seu interior, ao interagir com algo ou alguma coisa. Contudo, nem todos os sentimentos causados pelos efeitos do uso ou interação com o sistema são internos. Muitos dos efeitos podem ser causados pela aplicação de técnicas envolvendo o conceito de usabilidade e utilidade. Sendo assim, pode-se dizer em vias gerais que a usabilidade e utilidade de um produto auxiliam na promoção da experiência do usuário (MOGGRIDGE; ATKINSON, 2007; HARTSON; PYLA, 2012).

Outro ponto importante apontado por especialistas é que uma experiência de usuário não pode ser projetada. Ela é experimentada durante o uso de um produto ou sistema qualquer. A experiência de usuário ocorre em um determinado contexto de aplicação e depende do usuário e seu estado emocional o que vai sentir naquele instante de tempo. $\mathrm{O}$ mesmo projeto, aplicado em outro contexto, pode gerar uma experiência totalmente diferente para o mesmo usuário e também todos os demais (ANDERSON, 2011; HARTSON; PYLA, 2012).

O quanto é apresentado de impacto emocional durante a experiência, fica implícito que são questões referentes a diversão, estética/aparência, sensações, experimentação, originalidade e inovação. Em outras palavras, refere-se ao impacto emocional durante o processo de interação entre o usuário e o produto/sistema. Geralmente, usuários não se encantam mais por eficiência e eficácia dos produtos no mercado. Eles buscam "sentir" mais os produtos com os quais interagem (MOGGRIDGE; ATKINSON, 2007; HARTSON; PYLA, 2012).

É preciso compreender bem o projeto de um produto para que seja possível o mapeamento adequado aos usuários reais e na sequência utilizar as técnicas para maximizar a experiência positiva da interação com o produto. Para isso, é necessário definir os objetivos dessa experiência. Esses objetivos são, geralmente, de alto nível dentro de um projeto de interação, onde torna-se possível antecipar a experiência do usuário junto ao produto. Como exemplos de objetivos de experiência de usuário, pode-se citar fácil de usar, evitar erros para usuários esporádicos, alta satisfação do cliente, entre alguns outros (MOGGRIDGE; ATKINSON, 2007; ANDERSON, 2011).

Um ponto chave para auxiliar a atender os objetivos da experiência de usuário é a identificação dos usuários e quais seus perfis. Esse mapeamento facilita a comunicação das tomadas de decisões na construção do projeto e também na evolução e adaptação do sistema para o perfil do usuário. Uma das técnicas utilizadas para esse tipo de tarefa é a teoria de modelagem de usuário como Personas. Personas é uma técnica que tem sido aplicada em trabalhos de projeto 
de interfaces com o usuário. A seção 3.1 apresentará como a técnica de Personas auxilia no entendimento das necessidades e identificação do perfil do usuário real do sistema.

\subsection{ENTENDENDO O USUÁRIO UTILIZANDO PERSONAS}

Perfis de usuário são construídos através de informações detalhadas, coletadas em um processo interativo e vinculados com o objetivo principal do sistema, ao qual será utilizado pelo perfil. As informações que o compõe devem ser voltadas para o ponto principal do produto ou sistema. Informações pessoais sobre o usuário, sua familiaridade com a tecnologia, seu domínio sobre o assunto e informações que ele consegue descrever com relação ao produto testado (BARBOSA; SILVA, 2010).

Um perfil de usuário pode ser utilizado de diversas maneiras, inclusive para definir papéis e classes de usuário. Quando o objetivo é obter o perfil de usuário, a ferramenta mais adequada para essa tarefa são as Personas. Elas são criadas a partir de informações coletadas através de questionários, pesquisa de campo, grupo focal, base de dados sobre usuários, log de sistemas, entre outras informações. Personas são ótimas quando trabalhas em conjunto com histórias, cenários e encenações (HARTSON; PYLA, 2012).

Personas não são definidas como usuários reais, mas sim como arquétipos hipotéticos ou possíveis usuários do produto. Também pode ser definida como um personagem fictício capaz de representar um grupo de usuários reais com características similares (AQUINO JUNIOR; FILGUEIRAS, 2005; BARBOSA; SILVA, 2010; HARTSON; PYLA, 2012; MASIERO, 2013).

O uso de Personas faz-se importante para criar as funcionalidades corretas aos usuários corretos. Evitar discussões de projeto sem foco prioritário ao sistema é uma das suas principais características. O uso desta ferramenta auxilia na comunicação da equipe, facilitando e mantendo o foco no usuário (AQUINO JUNIOR; FILGUEIRAS, 2005; HARTSON; PYLA, 2012; MASIERO, 2013).

Ao se projetar um sistema é natural que o especialista pense em como será sua reação com a funcionalidade $\mathrm{X}$ dada a aparência Y. Porém, este tipo de comportamento, em muitos casos, leva a falha do produto. Personas auxiliam projetistas a não cometerem este equívoco, forçando-os a pensar como a Persona Maria, por exemplo, reagirá a uma determinada funcionalidade ou interface apresentada (HARTSON; PYLA, 2012).

A Persona pode ser classificada como primária ou secundária. A primária deve ser totalmente atendida no projeto final, devendo estar satisfeita e feliz com o produto. A melhor experiência ao interagir com o produto deve ser da Persona primária. Ao mesmo tempo, as Personas secundárias são atendidas com um alto grau de satisfação, porém com um percentual de satisfação sempre abaixo da primária (HARTSON; PYLA, 2012).

Para que a efetividade da ferramenta seja maior e também para identificar quem são as personas secundárias e quem é a primária, é importante que seja definido um cenário de interação. Um cenário é uma narrativa, seja ela textual ou através de figuras (pictóricas), concreta e 
com um alto nível de detalhes descrevendo pessoas executando alguma atividade (BARBOSA; SILVA, 2010).

A partir do momento que as informações do usuário e cenário estão definidas, é necessário fazer uma validação do sistema através de um método de avaliação da interface e interação do usuário. Alguns métodos são conhecidos em trabalhos de IHC. Eles têm o objetivo de minimizar erros que possam vir a acontecer no uso do sistema. A seção 3.2 apresenta um meio de realizar a atividade de avaliação da interface e interação do produto.

\subsection{AVALIANDO A INTERAÇÃO COM O USUÁRIO}

Existem muitos tipos de avaliação de interface e interação do usuário com o sistema. Alguns exemplos são a avaliação heurística, o percurso cognitivo, o teste com usuários, grupo focal, entre outros (BARBOSA; SILVA, 2010).

No percurso cognitivo um especialista narra o cenário e o usuário diz quais são as ações que devem ser tomadas no sistema. Testes com o usuário são realizados com o uso do sistema, onde especialistas devem fazer anotações e observações da interação e erros enquanto o usuário narra todos os seus pensamentos e passos em voz alta. O grupo focal, basicamente, é um grupo de usuários que vão discutindo sobre o que eles acharam do produto, onde tiveram dificuldades e se compreenderam o objetivo (BARBOSA; SILVA, 2010). Dentre todos, a avaliação heurística é o que tem o custo menor, é o mais simples de aplicar e também é o mais utilizado em projetos de avaliação de interação do usuário (TSUI et al., 2010).

A avaliação heurística é uma avaliação onde o especialista percorre sistematicamente todo o sistema buscando por problemas que venham impactar na usabilidade, e consequentemente podendo gerar uma experiência negativa de interação para o usuário (BARBOSA; SILVA, 2010; BENYON, 2011).

Esse método é composto por algumas diretrizes de usabilidade, onde é possível identificar se a interação e a interface possuem características desejadas e de alto valor para o usuário (BARBOSA; SILVA, 2010; BENYON, 2011). As diretrizes, também chamadas de heurísticas, mais populares entre os especialistas são as de Nielsen (1994), que foram as primeiras heurísticas apresentas com esse objetivo. Ao todo foram criadas 10 heurísticas com base em problemas frequentes encontrados por Nielsen (1994) ao longo de alguns anos de trabalho. A tabela 2 apresenta as 10 heurísticas originais de Nielsen.

Esse conjunto de heurísticas apresentado na tabela 2, pode ser considerado como mínimo e pode receber novas diretrizes com o intuito de expandir ou ajustar de acordo com a necessidade do projeto e avaliadores (BARBOSA; SILVA, 2010; BENYON, 2011).

Desde que sistemas robóticos começaram a coexistir com os seres humanos, pesquisadores de IHC e robótica começaram a se preocupar com as interações e também as interfaces entre os dois. A seção 3.3 apresenta os trabalhos relacionados envolvendo trabalhos que utilizam técnicas de IHC com o intuito de melhorar a interação entre os seres humanos e robôs. 
Tabela 2 - As 10 heurísticas de Nielsen

\begin{tabular}{c|l|l}
\hline ID & Heurística & Descrição \\
\hline 01 & $\begin{array}{l}\text { Visibilidade do estado } \\
\text { do sistema }\end{array}$ & $\begin{array}{l}\text { Sempre informar o usuário sobre o que está acontecendo no } \\
\text { sistema de maneira adequada e no tempo correto. }\end{array}$ \\
\hline 02 & $\begin{array}{l}\text { Correspondência entre } \\
\text { os sistemas e o mundo } \\
\text { real }\end{array}$ & $\begin{array}{l}\text { O uso de linguagens comuns para os usuários. A ordem das } \\
\text { informações devem manter uma sequência natural e lógica, } \\
\text { de acordo com o esperado pelo usuário. }\end{array}$ \\
\hline 03 & Controle e liberdade & $\begin{array}{l}\text { O sistema deve permitir que o usuário desfaça e refaça suas } \\
\text { ações. }\end{array}$ \\
\hline 04 & $\begin{array}{l}\text { Consistência e padroni- } \\
\text { zação }\end{array}$ & $\begin{array}{l}\text { Manter as convenções da plataforma ou do ambiente com- } \\
\text { putacional. }\end{array}$ \\
\hline 05 & $\begin{array}{l}\text { Reconhecimento em } \\
\text { vez de memorização }\end{array}$ & $\begin{array}{l}\text { As instruções do uso devem ser de fácil acesso no momento } \\
\text { que o usuário desejar. }\end{array}$ \\
\hline 07 & $\begin{array}{l}\text { Flexibilidade e eficiên- } \\
\text { cia de uso } \\
\text { malista }\end{array}$ & $\begin{array}{l}\text { Possibilidade de atalhos que facilitem a operação do sistema } \\
\text { por parte do usuário. Possibilidade de personalização da } \\
\text { interface. }\end{array}$ \\
\hline 08 & Prevenção de erros & $\begin{array}{l}\text { O sistema é capaz de contornar erros mantendo o seu funci- } \\
\text { onamento. }\end{array}$ \\
\hline 09 & $\begin{array}{l}\text { Ajude os usuários a re- } \\
\text { conhecerem, diagnosti- } \\
\text { carem e se recuperarem } \\
\text { de erros }\end{array}$ & $\begin{array}{l}\text { Uso de linguagem simples ao apresentar erros e mostrar ex- } \\
\text { plicitamente a solução para tal. }\end{array}$ \\
\hline 10 & Ajuda e documentação & $\begin{array}{l}\text { Uma boa documentação deve sempre estar disponível para } \\
\text { que o usuário possa acessar adequadamente. }\end{array}$ \\
\hline
\end{tabular}

Fonte: Nielsen (1994).

\subsection{A EXPERIÊNCIA DE USUÁRIO EM INTERAÇÕES COM ROBÔ}

Alguns trabalhos têm tratado experiência de usuário e técnicas de IHC para melhorar a qualidade de projetos em robótica social, de serviço e assistiva. Pesquisadores em experiência de usuário têm se mobilizado para entender como as pessoas estão se sentindo em relação a essa nova tecnologia e como melhorar a experiência com os robôs, principalmente os autônomos.

A técnica de GOMS (Goals, Operators, Methods and Selections) foi adaptada para entender projetos de interação humano-robô (IHR) como modelos de processamento humano. Assim, a modelagem de tarefas do robô em diversos cenários pode ter benefícios e maior eficiência na execução (DRURY; SCHOLTZ; KIERAS, 2007).

Clarkson e Ronald C Arkin (2007) apresentam um conjunto de heurísticas para a avaliação de projetos em IHR, vide tabela 3. A construção e validação desse conjunto foram feitas através da adaptação das heurísticas de Nielsen e Scholtz, e aplicação de métricas apresentadas no método de Nielsen. Com base nas métricas a avaliação deve ser realizada com 3-5 avaliadores e o total de problemas encontrados com as heurísticas deve estar em torno de 40-60\%, 
utilizando métodos e projetos diferentes. As avaliações entre sistemas diferentes não é estatisticamente relevante, porém como atenderam as métricas, os autores afirmam que podem ser utilizadas em outros projetos. As avaliações ocorreram em um robô para cenário de resgate. Após as adaptações das heurísticas, foi definido um conjunto com 8 heurísticas para sistemas de IHR.

Como mesmo propósito, porém em um domínio diferente, Elara et al. (2007) também apresenta um conjunto de heurísticas com o foco na interação humano e robô humanoide (IHRH) dentro do domínio de futebol. O conjunto apresentado é uma adaptação direta das 10 heurísticas de Nielsen. As heurísticas propostas tiveram uma resposta de aproximadamente $35 \%$ mais problemas encontrados do que as originais de Nielsen. O conjunto de heurísticas para IHRH são apresentadas na tabela 4.

O uso das heurísticas criadas por Clarkson e Ronald C Arkin (2007) é apresentado no trabalho de Manja Lohse, Hanheide et al. (2008). É construído um robô social que realiza interação com usuários ingênuos (que não tem contato prévio com robôs) durante uma visita guiada por uma casa. Para avaliar o sistema robótico construído, foi feita a avaliação heurística.

Com a avaliação, alguns pontos importantes foram apresentados. A avaliação e o desenvolvimento do projeto deve ser iterativo. Testes com usuários reais e ambientes reais apresentam melhores resultados. Os testes devem ser realizados com robôs totalmente autônomos, sem o uso da técnica de Wizard of $\mathrm{Oz}$ (WoZ) onde o robô é teleoperado sem o conhecimento do usuário durante o teste. As tarefas e contextos devem estar de acordo com o projeto do robô e as heurísticas devem ser incorporadas no projeto de construção do robô (LOHSE, Manja; HANHEIDE et al., 2008).

Manja Lohse, Hanheide et al. (2008) questionam ao final do trabalho, como essa avaliação heurística pode ser incorporada como métricas compreensivas para aceitação social de robôs reais e também como podem afetar o impacto social dos robôs. Isso deve ocorrer ao utilizar as heurísticas durante todo o projeto, sempre mantendo o foco no contexto de uso, especificações de projeto do robô e testes em ambientes reais. Dessa maneira, acredita-se que a criação de robô sociais atenderão as necessidades do usuário, tornando-o mais aceitável perante a sociedade.

Por ser um método de avaliação de interface com baixo custo, simples e com ampla aplicabilidade, o uso de heurísticas é utilizado em diversas pesquisas. Porém, de acordo com Tsui et al. (2010), nas aplicações do método é encontrado geralmente uma adaptação das heurísticas de Nielsen, por serem as pioneiras. A adaptação do método é feita para que domínios específicos sejam melhor atendidos (TSUI et al., 2010).

A criação de heurística sempre segue dois formatos: baseado em métodos de pesquisa ou em métodos empíricos. A validação é feita através de testes de usabilidade realizados empiricamente ou comparando com avaliações feitas através das heurísticas de Nielsen (TSUI et al., 2010). 
Tabela 3 - 8 heurísticas de IHR baseada nos conjuntos de Nielsen e Scholtz

\begin{tabular}{|c|c|c|}
\hline ID & Heurística & Descrição \\
\hline 01 & $\begin{array}{l}\text { Design de informações } \\
\text { suficientes }\end{array}$ & $\begin{array}{l}\text { As interfaces devem prover informações o suficiente para } \\
\text { que o usuário possa determinar se precisa intervir, mas tam- } \\
\text { bém não pode sobrecarregá-lo com excesso de informação. }\end{array}$ \\
\hline 02 & $\begin{array}{l}\text { Visibilidade do estado } \\
\text { do sistema }\end{array}$ & $\begin{array}{l}\text { O sistema deve sempre manter o usuário informado sobre } \\
\text { o que está acontecendo, através de um retorno com tempo } \\
\text { apropriadamente calculado. O sistema deve prover um mo- } \\
\text { delo do mundo real de maneira completa e permitir que o } \\
\text { usuário possa ver isso, tendo total entendimento da situa- } \\
\text { ção. O sistema deve auxiliar o usuário a ter consciência da } \\
\text { situação. }\end{array}$ \\
\hline 03 & $\begin{array}{l}\text { Apresentação apropri- } \\
\text { ada da informação }\end{array}$ & $\begin{array}{l}\text { A interface deve apresentar informações claras sobre os sen- } \\
\text { sores, que devem ser de fácil compreensão, e de maneira útil } \\
\text { ao usuário. O sistema deve utilizar o princípio do reconhe- } \\
\text { cimento por recuperação, externalização de memória. Deve } \\
\text { apoiar o gerenciamento da atenção do usuário. }\end{array}$ \\
\hline 04 & $\begin{array}{l}\text { Uso de sugestões natu- } \\
\text { rais }\end{array}$ & $\begin{array}{l}\text { A linguagem utilizada para a comunicação do sistema com } \\
\text { o usuário deve acontecer por palavras, frases e conceitos } \\
\text { familiares ao usuário e não em termos orientados a sistemas. } \\
\text { Seguir convenções do mundo real, apresentar informações } \\
\text { em ordem lógica e de maneira natural. }\end{array}$ \\
\hline 05 & $\begin{array}{l}\text { Síntese do sistema e in- } \\
\text { terface }\end{array}$ & $\begin{array}{l}\text { A interface e o sistema devem trabalhar como um só fa- } \\
\text { zendo com que a interface seja uma extensão do sistema, } \\
\text { do usuário e por representação, do mundo. A interface deve } \\
\text { facilitar de maneira eficiente e com eficácia a comunicação } \\
\text { entre o sistema e o usuário, em uma via dupla. }\end{array}$ \\
\hline 06 & $\begin{array}{l}\text { Ajudar o usuário a reco- } \\
\text { nhecer, diagnosticar, e } \\
\text { recuperar de erros }\end{array}$ & $\begin{array}{l}\text { O sistema com mal funcionamento deve se expressar atra- } \\
\text { vés da linguagem simples (sem códigos), precisamente in- } \\
\text { dicar o problema, e de maneira construtiva sugerir uma so- } \\
\text { lução. A informação deve ser suficiente a ponto do usuário } \\
\text { poder identificar se o ambiente contribuiu de alguma forma } \\
\text { ao problema. }\end{array}$ \\
\hline 07 & $\begin{array}{l}\text { Flexibilidade da Arqui- } \\
\text { tetura da Informação }\end{array}$ & $\begin{array}{l}\text { Se o sistema será utilizado por um longo período, a interface } \\
\text { deve ser capaz de suportar novos itens como capacidade de } \\
\text { sensores e atuadores, mudanças de comportamento e altera- } \\
\text { ções físicas. A capacidade de sensores e atuadores devem } \\
\text { ser adequados ao tipo de tarefa e ambiente esperados para o } \\
\text { sistema. }\end{array}$ \\
\hline 08 & $\begin{array}{l}\text { Projeto minimalista e } \\
\text { estético }\end{array}$ & $\begin{array}{l}\text { Informações do sistema deve ser apenas necessárias, sem o } \\
\text { uso de informações irrelevantes. O formato físico deve ser } \\
\text { agradável e de acordo com a função pretendida. }\end{array}$ \\
\hline
\end{tabular}

Fonte: Clarkson e Ronald C Arkin (2007).

No trabalho de Tsui et al. (2010) é proposto o desenvolvimento de heurísticas focadas em robôs assistivos. Utilizam, como ferramenta, um manipulador robótico montado em uma 
Tabela 4 - 8 heurísticas de IHRH adaptadas do conjunto de Nielsen

\begin{tabular}{|c|c|c|}
\hline ID & Heurística & Descrição \\
\hline 01 & $\begin{array}{l}\text { Visibilidade do estado } \\
\text { do sistema }\end{array}$ & $\begin{array}{l}\text { O sistema deve sempre manter o usuário informado sobre } \\
\text { o que está acontecendo, através de um retorno com tempo } \\
\text { apropriado. }\end{array}$ \\
\hline 02 & $\begin{array}{l}\text { Clareza na apresenta- } \\
\text { ção da informação }\end{array}$ & $\begin{array}{l}\text { A interface deve ser desenvolvida para apresentar de ma- } \\
\text { neira clara e compreensiva a informação de sensores e atu- } \\
\text { adores. }\end{array}$ \\
\hline 03 & $\begin{array}{l}\text { Correspondência entre } \\
\text { o sistema e o mundo } \\
\text { real }\end{array}$ & $\begin{array}{l}\text { A linguagem utilizada para a comunicação do sistema com } \\
\text { o usuário deve acontecer por palavras, frases e conceitos } \\
\text { familiares ao usuário e não em termos orientados a sistemas. }\end{array}$ \\
\hline 04 & $\begin{array}{l}\text { Posicionamento priori- } \\
\text { tário de informações }\end{array}$ & $\begin{array}{l}\text { Posicionamento prioritário dos botões de controle de acordo } \\
\text { com a importância e frequência de uso. }\end{array}$ \\
\hline 05 & $\begin{array}{l}\text { Estendibilidade do sis- } \\
\text { tema }\end{array}$ & $\begin{array}{l}\text { O sistema deve permitir a evolução, como inclusão de sen- } \\
\text { sores, atuadores, componentes de comportamento e habili- } \\
\text { dades. }\end{array}$ \\
\hline 06 & $\begin{array}{l}\text { Ajudar o usuário a reco- } \\
\text { nhecer, diagnosticar, e } \\
\text { recuperar de erros }\end{array}$ & $\begin{array}{l}\text { O sistema com mal funcionamento deve se expressar atra- } \\
\text { vés da linguagem simples (sem códigos), precisamente in- } \\
\text { dicar o problema, e de maneira construtiva sugerir uma so- } \\
\text { lução. Informações abstratas do robô humanóide que o am- } \\
\text { biente pode prover para o usuário com fins de depuração. }\end{array}$ \\
\hline 07 & $\begin{array}{l}\text { Arquitetura de comuni- } \\
\text { cação efetiva }\end{array}$ & $\begin{array}{l}\text { A interface e o sistema devem trabalhar como um só fa- } \\
\text { zendo com que a interface seja uma extensão do sistema, } \\
\text { do usuário e por representação, do mundo. A interface deve } \\
\text { facilitar de maneira eficiente e com eficácia a comunicação } \\
\text { entre o sistema e o usuário, em uma via dupla. }\end{array}$ \\
\hline 08 & $\begin{array}{l}\text { Projeto minimalista e } \\
\text { estético }\end{array}$ & $\begin{array}{l}\text { Informações do sistema deve ser apenas necessária, sem o } \\
\text { uso de informações irrelevantes. O formato físico deve ser } \\
\text { agradável e de acordo com a função pretendida. }\end{array}$ \\
\hline
\end{tabular}

Fonte: Elara et al. (2007).

cadeira de rodas que se movimenta através de teleoperação. Durante a pesquisa, foram encontrados quatro erros de grande impacto no sistema: segurança; confiança; erros do sistema; e flexibilidade. Para cobrir esses erros foram criadas heurísticas adicionais com base nas de Nielsen, na literatura de acessibilidade e robótica social.

O conjunto de heurísticas exclusivo para robótica assistiva, com o mesmo cenário de teleoperação, apresentou resultados melhores que as de Nielsen. De 39 problemas, as heurísticas de Nielsen são capazes de cobrir apenas 13, enquanto as heurísticas adaptadas cobriram 33. O teste foi realizado apenas com 2 avaliadores, e precisam de mais experimentos para uma avaliação mais significativa (TSUI et al., 2010).

Um estudo empírico em experiência de usuário foi realizado através de interações com o robô por voz. Kristiina Jokinen e Wilcock (2013) apresentam uma maneira de realizar uma avaliação da interação por voz dando ênfase ao que o usuário realiza para se comunicar com o robô e também em seu processo cognitivo durante a interação. A atividade comunicativa do 
usuário se correlaciona com o sistema. A correlação é estabelecida a partir da avaliação do próprio usuário onde ele informa ao final do processo se foi uma experiência positiva para ele.

A experiência não é medida apenas com a informação de sucesso pelo próprio usuário e sua adoção ao sistema após a interação com o robô, mas também com o processo psicológico que refere-se a atenção, motivação e percepção do usuário durante o cenário executado (JOKINEN, K.; WILCOCK, 2013).

Os resultados foram promissores e mostraram que a experiência do usuário caminha para uma direção natural de interação. Contudo, um estudo mais aprimorado sobre a percepção e cognição é necessário, assim como a adição de variáveis para o estudo (JOKINEN, K.; WILCOCK, 2013).

Uma empresa operava em sua linha de produção com um antigo manipulador robótico. Este antigo manipulador possuía uma grade de proteção, impedindo que os usuários se aproximassem dele. Agora, um novo manipulador foi instalado na linha de produção. O novo manipulador não possui a grade de proteção, pois os usuários podem trabalhar em conjunto com o robô, durante o processo de embalagem do produto. Após a instalação do novo manipulador robótico, Buchner et al. (2013) investigam qual seria a experiência do usuário ao utilizá-lo nas tarefas da fábrica. Uma variável relativa ao tempo de uso da tecnologia foi adicionada ao experimento, com o intuito de identificar o comportamento do usuário conforme o passar dos dias de trabalho. Para isso, questionários foram aplicados em diferentes tempos da produção. $\mathrm{O}$ primeiro foi realizado no momento da inauguração do novo manipulador. Esses questionários foram distribuídos entre os operadores do novo robô, e do antigo robô que já estava na fábrica a mais de 10 anos. Mais duas rodadas de questionários foram realizadas, após 12 e 18 meses da instalação do robô.

Resultados apontam que o usuário se acostuma com a tecnologia ao longo do tempo e a experiência não apresenta diferenças após um período. Contudo, não quer dizer que houve melhora na experiência do usuário com o passar do tempo. Principalmente tratando-se de um robô industrial, o usuário acaba interagindo por obrigação e dever a cumprir com a empresa. Mais pesquisas devem ser realizadas para obter detalhes dos fatores que são importantes e realmente influenciam a experiência do usuário ao longo do tempo (BUCHNER et al., 2013).

Um estudo sobre uma interface de controle para robôs de regaste é realizado através de avaliações heurísticas. A melhora da interface é proposta após a identificação de alguns erros. Naveed, Rao e Mertsching (2014) identificam alguns pontos que são problemas de interação com a interface de controle através de uma avaliação empírica e sem o uso de heurísticas já definidas para o domínio. Após a identificação dos erros, é proposto uma nova interface de controle do sistema.

Saariluoma e Jussi P. P. Jokinen (2014) aborda o conceito chamado psicologia de usuário. O objetivo é utilizar conceitos, teorias e resultados de estudos psicológicos, como meio para estruturar problemas em investigações sobre interações entre humanos e computadores. Três estudos são apresentados com cenários em diferentes tecnologias voltadas a interação. 
Dois estudos são em laboratório e um em campo. Com os resultados extraídos dos estudos é proposto um modelo para melhorar o compreendimento de aspectos emocionais da experiência do usuário.

Uma maneira para definir emoção é como sendo parte crítica para uma tomada de decisão efetiva, assim como uma maneira melhor de aprender sobre algo ou situação. O foco da pesquisa apresentada por Saariluoma e Jussi P. P. Jokinen (2014) é em questionários sobre emoções básicas, que são a base de investigações sobre psicologia de usuário em tecnologia envolvendo a base de conceitualização, definições operacionais, interpretação de resultados e explicação de resultados.

Os resultados obtidos através dos experimentos conduzidos foram representações mentais sobre experiência de usuário emocional com o foco principal sobre o efeito de emoções básicas na experiência durante a interação. Para realizar os experimentos de maneira empírica os usuários foram solicitados a refletir sobre como estavam se sentido e expressar-se através das palavras que representavam tais emoções. Assim, foi possível encontrar dois grupos entre as emoções básicas, o positivo nomeado de competências e o negativo como frustrações. Com eles é possível realizar o mapeamento do estado mental da pessoa. Esse modelo é chamado de modelo bipolar competência-frustação (SAARILUOMA; JOKINEN, J. P. P., 2014).

Investigações sobre como comportamentos multimodais do usuário podem auxiliar a medir o compromisso durante a interação com o robô, são conduzidas por Kristiina Jokinen e Wilcock (2015). Foram mapeadas diversas combinações de comportamentos do usuário, como direção do olhar, expressões faciais, e postura corporal, para auxiliar na predição da experiência do usuário e avaliação da interação por voz entre 5 categorias, capacidade de resposta, expressividade, interface, usabilidade e impressões gerais.

Após determinar as características para cada comportamento do usuário e também para algumas ações do robô, foi utilizado algoritmos de regressão logística e support vector machines (SVM) para classificá-los entre as cinco categorias de interação mapeadas (JOKINEN, K.; WILCOCK, 2015).

Como a diferença estatística entre os dois algoritmos não demonstrou representatividade, optou-se por utilizar o SVM. Cada comportamento contribui para classificar uma determinada categoria porém, essas informações são muito complexas e necessitam de mais características para aumentar a acurácia da classificação (JOKINEN, K.; WILCOCK, 2015).

Broadbent (2016) apresenta um guia, no ponto de vista psicológico, sobre quais pontos devem ser estudados para aprimorar a compreensão da interação humano robô de maneira a otimizar o comportamento do robô. O trabalho apresenta conceitos, teorias e modelos de interação humano-humano na psicologia.

Um estudo de caso investiga a experiência do usuário ao trabalhar de forma colaborativa com um robô fixo, em uma linha de produção de veículos. Após trabalharem por três semanas, os usuários que trabalharam em parceria com o robô foram entrevistados utilizando técnicas de questionários em usabilidade. Os usuários sentiram-se limitados com o auxílio do robô. Ele 
delimita consideravelmente o espaço de trabalho e também a velocidade que cada indivíduo realiza as tarefas ao longo da jornada de trabalho (WEISS; HUBER, 2016).

Esse tipo de comportamento resultou em uma perda de produtividade e impacto direto na experiência do usuário ao compartilhar as tarefas com o robô. Dado o cenário de experiência de usuário ruim, a primeira tomada decisão na empresa foi regulamentar algumas soluções técnicas fazendo com que o usuário se adapte melhor ao trabalho colaborativo, por exemplo, treinamentos e sequências de ações no trabalho. Na sequência, fatores de experiência de usuário devem ser melhor investigados e agregados ao projeto do robô de maneira a aprimorar o cenário (WEISS; HUBER, 2016).

Trabalhos com experiência de usuário em reabilitação de pacientes também é investigado por pesquisadores da área. Shirzad e Van der Loos (2016) utilizaram um manipulador robótico, construído pelos pesquisadores, para auxiliar nos casos de reabilitação de pacientes que sofreram danos cerebrais. Para isso, foi construído uma espécie de jogo, onde o usuário deve posicionar uma bolinha em regiões da tela do computador utilizando o manipulador robótico. O manipulador auxilia na força que o usuário exerce, tentando predizer o movimento do paciente. Essa tarefa tornou-se divertida e aumento o número de sucesso na reabilitação dos pacientes.

Lindblom e Andreasson (2016) defendem o uso das técnicas de experiência de usuário em robótica social, que em geral são dadas como certas nos projetos de interação humano-robô. Porém, elas devem ser desenvolvidas de maneira sistemática e com sua devida avaliação. De acordo com Lindblom e Andreasson (2016), este é o melhor caminho para o desenvolvimento de robôs sociais que possuam uma maior aceitação no mercado. Desenvolver uma experiência de usuário positiva é importante, pois auxiliam em aspectos que aumentam a aceitação, usabilidade e credibilidade dos sistemas robóticos em âmbito social. Para auxiliar os futuros projetos de robótica, os autores apresentam 3 desafios que devem ser investigados ao longo dos próximos anos:

a) Necessidade de criar um processo iterativo de projeto de experiência do usuário (UX, em inglês): este é um problema devido ao alto custo de realizar protótipos robóticos de maneira rápida. O número de hardware e software utilizados não colaboram para o uso de um processo iterativo;

b) Necessidade de estabelecer metas de UX para garantir uma experiência positiva: essas metas são expressadas como facilidade de uso, facilidade de aprendizado, aceitação e excitação emocional. As metas de UX não podem ser confundidas como o comportamento e/ou funcionalidades que o robô possui;

c) Necessidade dos projetistas de robótica adquirirem conhecimento adequado sobre as metodologias de avaliação de UX, tanto em teoria quanto em prática.

É importante olhar cada um desses desafios, pois a aplicação de UX em IHR fará com que os robôs sociais sejam melhor aceitos em diversos ambientes e por pessoas dos mais diferentes perfis (LINDBLOM; ANDREASSON, 2016). Em relação ao primeiro desafio de criar 
um processo iterativo de projeto de UX, acredita-se que a definição de uma arquitetura em componentes que possam ser utilizados como blocos para construção de um robô social, possa ser o caminho adequado para diminuir o custo e tempo de gerar um protótipo para testes de IHR. Essa tese contribui com o desafio do item b, necessidade de estabelecer metas de UX para garantir uma experiência positiva. Também a uma pequena contribuição no item c, onde são apresentadas algumas técnicas relacionadas a experiência de usuário.

Robôs construídos para serviços no setor de agricultura encontram muitas dificuldades, e quando são totalmente autônomos, no geral, possuem diversas limitações devido ao ambiente sem controle e aberto. Os robôs teleoperados foram melhores aceitos para o trabalho. Eles apresentaram resultados $4 \%$ melhores que a execução da tarefa por seres humanos e $14 \%$ melhores os robôs autônomos realizando a tarefa. Com base nesse cenário, Adamides et al. (2017) conduzem uma pesquisa sobre a melhor configuração de interface para o usuário operar o robô. Três variáveis foram consideradas para montar a configuração de interface, são elas: (I) tipo de saída de vídeo (monitor ou capacete de realidade virtual); (II) número de visões ou telas (única ou múltiplas); e (III) tipo de controle do robô (joystick ou teclado).

Testes com operadores foram conduzidos para verificar a resposta perante cada configuração. Em seguida, questionários foram aplicados para identificar as configurações que guiaram uma melhor experiência. O uso de múltiplas telas foi a melhor configuração para a variável, pois potencializa a visão do usuário referente a localização do robô e a área da tarefa. A visão através da tela contribui menos que o uso do capacete, quando se tratado da carga de trabalho exercida pelo usuário. Por fim, a interface via teclado teve melhor resposta na eficiência do trabalho perante o joystick. Estudos de representações espaciais devem continuar com o intuito de elevar mais a experiência do usuário na manipulação do robô (ADAMIDES et al., 2017).

Algumas pesquisas discutem a importância dos estudos aplicados a robôs domésticos. McGinn, Sena e Kelly (2017) conduziram um estudo para verificar a aptidão dos usuários novatos em controlar o robô pelo ambiente doméstico através de um controle. Os usuários selecionados nunca tiveram contato direto com robôs reais. Para realizar o teste, construiu-se um ambiente virtual e os usuários tinham que realizar a navegação pela casa virtual.

As observações feitas durante o teste demonstraram que os usuários não possuem destreza para executar a tarefa. Houve um número alto de colisões, principalmente durante a transição pela região das portas da residência e corredores estreitos. Os controles demonstram que as técnicas na criação de uma interface para controle do robô não apresentam uma usabilidade adequada e promovem uma experiência ruim ao usuário, ponto que será trabalho no futuro (MCGINN; SENA; KELLY, 2017).

Alguns trabalhos fizeram a adaptação da técnica de Personas (vide seção 3.1) para utilizar na interação humano-robô. Nem sempre a Persona foi utilizada no formato de trabalhos na área de interação humano computador. Às vezes, são utilizadas apenas como diferentes personalidades do robô dado um determinado cenário de atuação. Os trabalhos a seguir apresentam o uso da técnica de Personas em IHR. 
Geralmente, os pesquisadores apresentam trabalhos voltados para robôs que possuem uma personalidade compatível com a do ser humano em busca de melhorar a interação. Contudo, não existem provas que a compatibilidade de personalidade influencia na melhora da interação entre humanos e robôs. A pesquisa realizada por Woods et al. (2005) explora alternativas para que o robô possuir personalidades compatíveis com as do ser humano. Para isso, foi utilizado um robô não humanoide com dois tipos de comportamentos implementados: interativo social e ignorante social. Ao todo 28 participantes interagiram com o robô por duas vezes, um com cada comportamento. A interação ocorreu em um cenário de sala de estar, onde o robô deveria interagir como se fosse a recepção de uma visita. Na sequência da interação, os participantes preenchem um questionário atribuindo uma pontuação sobre o comportamento do robô. O participante deve dizer também o quanto ele identificou a personalidade do robô, com sua personalidade.

Woods et al. (2005) perceberam que no geral, os participantes não identificaram sua personalidade parecida com a do robô. Eles, inclusive, acreditam que suas personalidades são no geral, mais fortes que as apresentadas pelo robô durante o processo de interação. De acordo com as respostas obtidas, a percepção sobre a personalidade do robô está ligada a fatores como idade, gênero e experiência tecnológica. Essas variáveis apresentam uma separação de grupos consistente para Woods et al. (2005). A investigação sobre robôs com personalidades deve seguir para os próximos trabalhos, com o intuito de identificar o quanto a personalidade de um robô pode afetar uma interação.

Uma abordagem com tipos de robôs não convencionais é a chave para a aceitação desses agentes nas residências, pelo menos é a hipótese criada por Ljungblad et al. (2006). Essa hipótese nasceu a partir de uma análise de donos de animais exóticos, como aranhas e lagartos. Ao observar esse tipo de animal como animal de estimação, nota-se que o ser humano pode se sentir à vontade com outros bichos em casa, além de cães e gatos. Existem pesquisas voltadas para projetos de robôs com aparências diferentes das convencionais. Esses robôs são chamados de agentes pessoais embarcados. São encontrados, geralmente, em ficção científica, e possuem uma aparência diferente, mais próxima de um objeto cotidiano. Agentes pessoais embarcados são capazes de interagir com outros agentes, inclusive o ser humano, e também interagem direto com o mundo físico.

Para identificar as possibilidades de projetos para agentes pessoais embarcados, com foco em ambientes domésticos, Ljungblad et al. (2006) realizaram uma entrevista com donos de animais domésticos exóticos. Foram selecionados seis homens e quatro mulheres, com idade entre 17 e 55 anos. As entrevistas ocorreram presencialmente ou por telefone, para diminuir o custo de deslocamento da pesquisa. O objetivo das entrevistas era coletar informações para identificar possíveis aparências que um agente pessoal embarcado poderia ter. A partir das informações coletadas quatro Personas foram criadas apresentando personalidades e interesses em agentes embarcados específicos. Cada Persona gerou um tipo de projeto de robô para ambientes domésticos. No geral foram criados como aparência de móveis, que possuem uma 
dinâmica estética. Além disso, proporcionam uma extensão da identidade social da pessoa e compartilha o mesmo interesse que a pessoa. Ljungblad et al. (2006) querem estender o estudo e construírem diferentes tipos de agentes pessoais embarcados para atender o público geral.

Meerbeek, Saerbeck e Bartneck (2009) apresenta em seu trabalho uma orientação para construir robôs autônomos. Na definição de Meerbeek, Saerbeck e Bartneck (2009) um robô autônomo precisa induzir uma percepção de sua personalidade através de seu comportamento e aparência. A personalidade facilita a interação entre os agentes. Além disso, com a personalidade devida é mais fácil existir uma expressão de sentimento para o agente. Após a definição de toda a orientação de projeto para identificar possíveis personalidades do robô, Meerbeek, Saerbeck e Bartneck (2009) dizem que as personalidades de um robô podem ser descritas como Personas. Futuras pesquisas continuarão para a aplicação do guia de orientação criado por eles.

Uma análise sobre estudos em interação humano-humano é apresentada por Zlotowski, Weiss e Tscheligi (2011). Nesse estudo, é realizado um levantamento sobre o processo de escolha de um parceiro para interação. Com base nas informações coletadas foram criados Personas para um cenário público de interação humano-robô. As Personas foram utilizadas para criar os comportamentos do robô, garantindo que fossem mais naturais possíveis. Como um teste piloto, o processo de criação de Personas como auxilio para o projeto de robô apresentou uma bons avanços. Como próximo passo, Zlotowski, Weiss e Tscheligi (2011) querem identificar como expandir esse modelo para diferentes cenários de atuação.

Um trabalho conceitual é apresentado por Ruckert (2011). Nele é discutido a possibilidade da criação de um robô que possa assumir diferentes Personas. O intuito é fazer com que o robô possa definir sua personalidade através Persona incorporada diante a situação de interação. Esse conceito é chamado de Robot Persona. O trabalho continuou em Ruckert et al. (2013), onde ele apresenta a aplicação de padrões de interação voltados à aplicações em robótica. Padrões de interação são caracterizações das características essenciais em interação social. São criados com base em uma especificação abstrata e que pode ser utilizado em diferentes situações para atingir problemas semelhantes.

O uso de padrões de interação em robótica social é importante, pois o robô tende a preencher papeis em sociedade, como de enfermeiras, recepcionistas e assistentes pessoais. Todos esses papéis desempenham tarefas complexas e que exigem uma interação social intensa. Com o foco nessa característica do problema, Ruckert et al. (2013) criaram Personas com base na interação das pessoas em diferentes situações no mundo real. As Personas criadas carregam diferentes atuações para 15 padrões de interação (introduction, didactic communication, in motion together, directing other's activity, personal interest and history, recovering from mistakes, reciprocal turn-taking in game context, physical intimancy, prosocial request, polite conversation, compliment, dry humor, claiming responsability, claiming unfair treatment, asserting authority). Dependendo da situação o robô assumi uma Persona para interagir de maneira apropriada em cada situação. As Robot Personas foram aplicadas e testadas utilizando o padrão de intereação introduction para culturas diferentes. A sequência do trabalho, após os primeiros re- 
sultados positivos, é expandir a aplicação desse tipo de técnica em outros cenários e com outros padrões de interações envolvidos (RUCKERT et al., 2013).

Robôs de companhia precisão atender a necessidade do usuário. O desafio é identificar como adaptar o comportamento do robô para cada usuário, sem utilizar uma grande base de dados para treinamento e sem a necessidade de coletar informações para treinamento. A solução apresenta por Duque et al. (2013) é a utilização de Personas para auxiliar na construção dos comportamentos do robô. As Personas definem o comportamento, objetivo e atitudes do robô, de acordo com o usuário. Como um guia para construção das Personas utilizam o modelo computacional comportamental, que define um conjunto de valores estatísticos sobre usuários. O modelo apresentado por Duque et al. (2013) é chamando de modelo computacional comportamental baseado em Personas.

Para conseguir criar o modelo, Duque et al. (2013) realizou um questionário com o objetivo de entender o que os usuários esperavam de um robô de companhia e quais seriam suas preferências para o robô. Foi realizado um teste inicial com comportamentos criados com base nas seguintes variáveis: idade, gênero, nível de escolaridade, conhecimento tecnológico, experiência computacional, experiência prévia e conforto com robôs, traços de personalidade do usuário (utilizou o conceito do Big Five Personality, que é um questionário que determina qual a personalidade da pessoa), o papel exercido pelo robô e a preferência de proximidade na interação. Após os testes iniciais as Personas foram atualizadas para correção de alguns pontos de comportamento do robô. Duque et al. (2013) ampliará os testes para identificar novas Personas para incrementar os comportamentos dos robôs de companhia.

Dado os trabalhos que falam sobre experiência de usuário na literatura, uma discussão ampla é guiada por Alenljung et al. (2017). A investigação na literatura sobre aplicação das técnicas voltadas para trabalhos com experiência de usuário em projetos de interação entre humanos e robôs sociais é feita com algumas críticas. Eles defendem que as técnicas devem ser adaptadas e empregadas de maneira correta ao longo do projeto de criação de robôs sociais, de serviço e assistivos, em principal os autônomos. Para isso, é necessária uma exploração das técnicas de projetos e avaliação de experiência de usuário, para que sejam adaptadas de maneira adequada as realidades dos projetos de IHR. Apesar de existirem trabalhos voltados para que haja uma boa experiência de interação, não existe aplicação de maneira sistemática das técnicas de UX para garantir uma experiência positiva. Trabalhar com as técnicas tradicionais de maneira adaptada pode ser um caminho para otimizar o tempo de aceitação do robô na sociedade, tornando uma área muito importante para estudos e pesquisas dedicadas (ALENLJUNG et al., 2017). 


\section{MÉTODO CENTRADO NO USUÁRIO PARA PROJETOS DE INTERAÇÃO HUMANO- ROBÔ}

Esse capítulo é dedicado a apresentação do método centrado no usuário para construção de robôs autônomos que serão utilizados em tarefas de interação com seres humanos. Primeiro passo realizado foi a definição das fases necessárias para construir um projeto de interação entre humanos e robôs, de acordo com os estudos realizados sobre os modelos de processos de desenvolvimento de software. Entre os modelos apresentados na literatura, existem duas grandes categorias dentre os modelos, são elas: os prescritivos ou tradicionais e os métodos ágeis.

A primeira categoria, os modelos prescritivos, tem como principal característica a definição de limites claros entre as fases do projeto. $\mathrm{O}$ foco dos modelos prescritivos está em grande parte na documentação presente em todas as fases do processo, e não apenas no código-fonte do sistema. Dentre os modelos prescritivos existem dois modelos que são base para os demais, modelo cascata e o modelo espiral (SOMMERVILLE, 2008; WAZLAWICK, 2013).

O modelo cascata tem como maior característica a execução das tarefas de maneira sequencial, onde cada tarefa está contida em fases. Cada fase do processo possui o escopo bem definido. Este modelo foi utilizado por muito tempo, porém ele não tinha uma realimentação no processo de maneira que qualquer evolução deve ser tratada como um novo projeto. Com essa característica, algumas variações foram apresentadas para mitigar esse problema, como o cascata em V, em W e o em subprojetos (WAZLAWICK, 2013). A documentação gerada no modelo cascata tem o objetivo de retratar o código produzido pela equipe de desenvolvimento, de maneira mais abstrata possibilitando um melhor entendimento do projeto por todos envolvidos.

Como uma evolução do modelo cascata e suas variações, surgiu o modelo espiral. Sua principal característica é a prototipação segmentada e cíclica. Esse ponto auxilia na mitigação dos riscos envolvendo o negócio do projeto. O trabalho com ciclos de interação é positivo, pois possibilita a documentação da evolução do projeto. O histórico de evolução é importante para identificar tomadas de decisões de problemas recorrentes e possíveis criações de padrões de projetos.

A segunda categoria dos modelos de processo de software, os modelos ágeis, tem como principal objetivo diminuir as definições das atividades e trabalhar de forma mais prática. Esse modelo é voltado a fatores humanos do desenvolvimento. Isso não quer dizer que os métodos ágeis sejam desprendidos de documentação ou que sejam simples demais. O principal ponto destes métodos é focar nos resultados e não no processo formal como um todo (SOMMERVILLE, 2008).

Dentre os modelos ágeis, os mais conhecidos são o SCRUM e o XP (eXtreme Programming). O SCRUM é uma metodologia focada na gestão de projetos. O objetivo é dividir o projeto em pequenos grupos de entregas chamados de sprints, ou seja, corridas rápidas de de- 
senvolvimento. Cada sprint tem duração de 2 a 4 semanas, entre valores mínimo e máximo. Ele é recomendado para grandes projetos e com uma equipe bem inflada. Dessa forma, é possível ter um controle e indicadores de evolução do projeto de maneira mais rápida. Isso possibilita que mudanças de negócios e riscos sejam detectados e mitigados em um prazo menor (SUTHERLAND, 2016). O SCRUM ele segue uma linha de raciocínio parecida com o modelo espiral, porém o prazo entre os ciclos são pré determinado através dos sprints.

$\mathrm{O}$ XP é um modelo ágil mais indicado à equipe de desenvolvimento. Ele é baseado em valores, princípios e regras. Por ser um modelo mais simples, ele é recomendado a equipes de pequeno e médio porte. Os princípios trabalhos dentro do XP são: simplicidade, respeito, comunicação, feedback e coragem. Por ser um modelo voltado a equipe de desenvolvimento, não existe uma forma para condução do projeto como um todo. O objetivo é direcionar a equipe com boas práticas na condução do trabalho. Além do SCRUM e o XP, existem outros modelos ágeis, como o Lean, Crystal e o Feature Driven Development (FDD) (WAZLAWICK, 2013).

$\mathrm{O}$ uso de modelos ágeis é interessante quando o projeto possui mudanças de negócios com uma frequência mais elevada, dentro de um curto espaço temporal. Nesta tese é fundamental adotar um modelo de desenvolvimento de software, pois fica mais claro identificar as fases de cada parte do projeto de interação humano-robô, além de deixar mapeado os passos necessários para evolução do projeto (SOMMERVILLE, 2008; WAZLAWICK, 2013).

O modelo de negócio aplicado a robótica de serviços em um âmbito geral, é voltado mais a pesquisa do que o mercado propriamente. Sendo assim, é importante que o método para projetos em interação humano-robô possua iterações cíclicas onde seja contemplado sua evolução. Entretanto, o uso de metodologias ágeis não é recomendado, pois é necessário um amadurecimento de documentação e estrutura do projeto, que as metodologias ágeis não possuem uma boa governança. Nesse caso, o modelo de processo de software mais indicado é o modelo espiral, pois atende os quesitos de documentação necessários e também possui a vantagem de ser iterativo. Dessa maneira, cada ciclo do projeto, pode ser considerado um novo versionamento do projeto de interação humano-robô.

É proposto nesta tese, um modelo espiral que contempla 4 fases: concepção, construção, teste e análise. Esse modelo proposto com base no modelo de processo tradicional espiral (SOMMERVILLE, 2008) é ilustrado através da figura 3.

$\mathrm{Na}$ fase de concepção é realizado o levantamento inicial das necessidades do projeto. Nesse levantamento todas as definições e contextualizações são realizadas. As definições de escopo, variáveis de observação, contexto de uso, questionário pré e pós teste, perfil do grupo de usuários pra execução dos testes, funcionalidades do robô, sensoriamento e atuadores, cenário de teste e submissão do projeto ao comitê de ética.

A próxima fase é a da construção, nela é realizado algumas definições mais técnicas do robô como arquitetura de software e construção física do robô, e a implementação dos mecanismos de decisão e controle do robô. Além disso, nessa fase são realizados alguns testes pilotos para obter as características dos perfis do publico alvo. Com essas informações podem 
Figura 3 - Modelo de processo para IHR proposto nesta tese com base no modelo espiral.

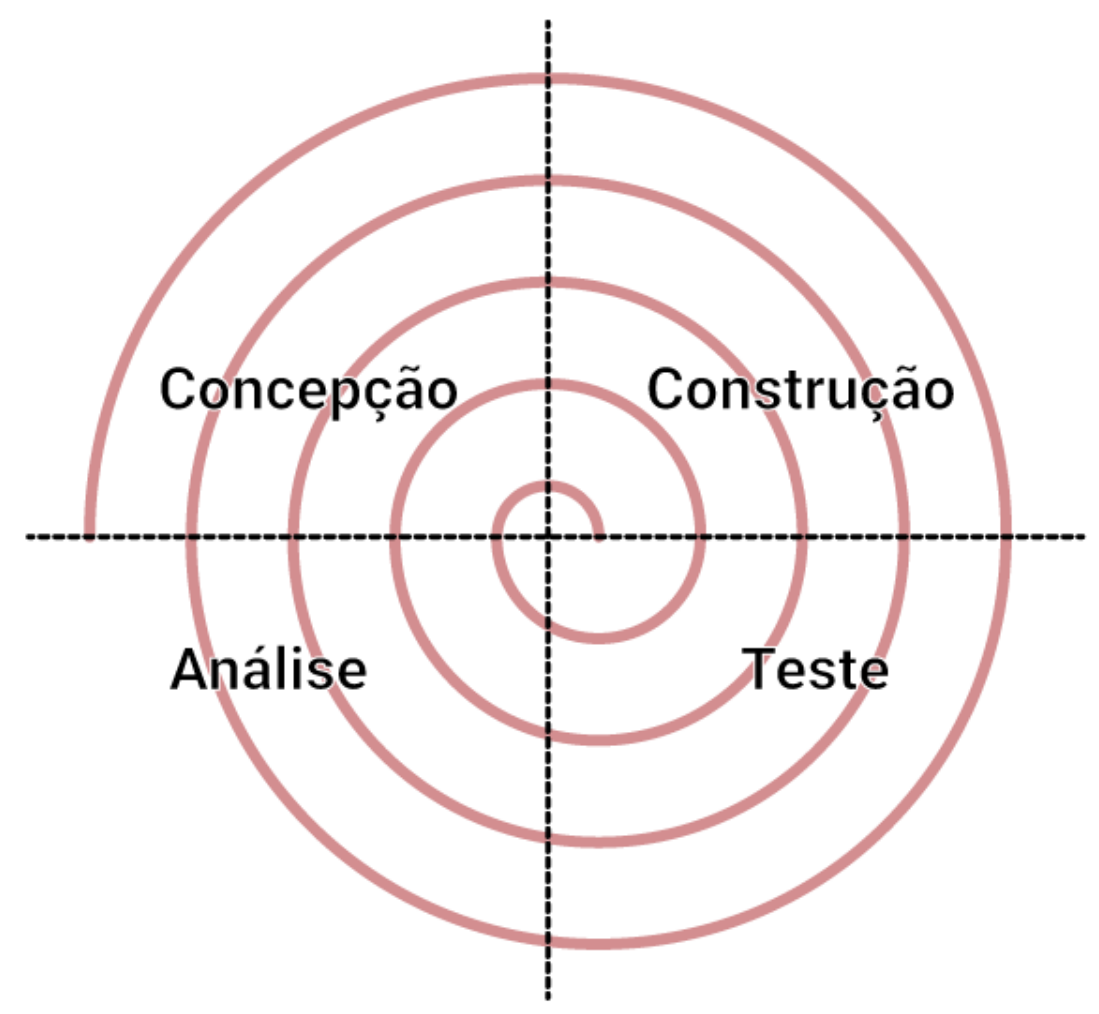

Fonte: o autor.

ser trabalhadas as Personas que servirão de base para o projeto. Com base nas Personas, ajustes devem ser realizados para atender melhor as expectativas dos usuários durante a interação com o robô. A interação deve ser de maneira totalmente autônoma, pois deixará o resultado dos testes mais naturais e reais ao cenário.

Como apresentado na figura 3 a sequência do projeto é a bateria de testes realizadas com os usuários diferentes dos testes piloto. Nessa fase o mais importante é realizar a coleta de informações que são utilizadas na fase de análises. A fase de análise é a última fase do ciclo do modelo de desenvolvimento de um projeto de robô autônomo que interage com humanos. Nela deve-se realizar testes estatísticos a fim de validar hipóteses nulas levantadas na definição do escopo. Além disso, discussões com bases em resultados qualitativos também são realizados. Eles auxiliam na definição e nos procedimentos que deverão ser executados na próxima iteração do modelo espiral. Uma visão geral do ciclo proposto nesta tese é apresentada através da figura 4.

Uma explicação detalhada sobre cada etapa contida nas 4 fases do método são apresentadas ao longo do restante deste capítulo. 
Figura 4 - Detalhamento do processo apresentado no método proposto por essa tese.

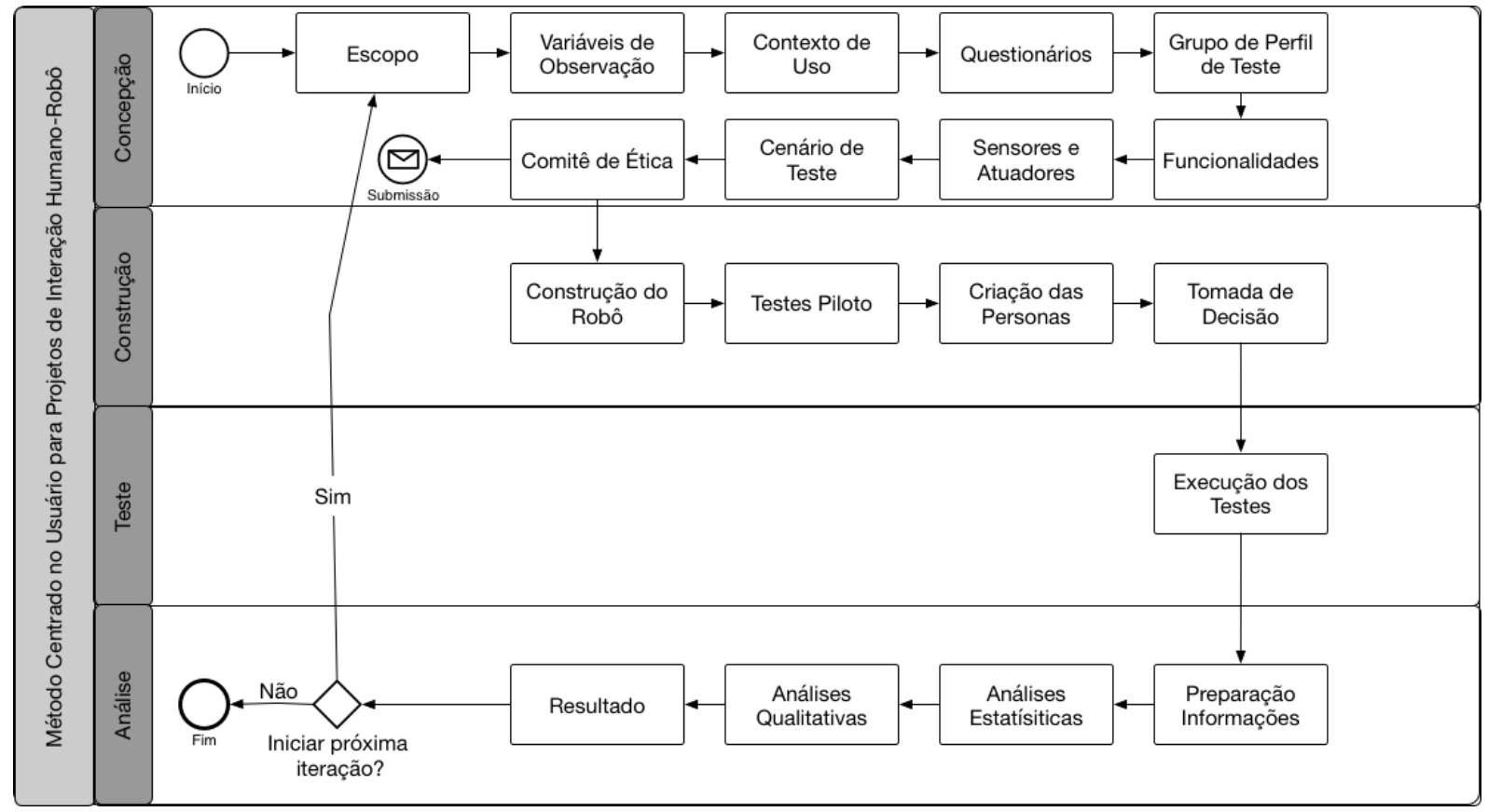

Fonte: o autor.

\subsection{CONCEPÇÃO DO PROJETO DE INTERAÇÃO HUMANO-ROBÔ}

Essa seção apresentada os detalhes que devem ser contemplados na fase de concepção do projeto de interação humano-robô, utilizando robôs autônomos. Esse é uma etapa importante para a metodologia proposta, pois auxilia na construção de um robô centrado no usuário e capaz de realizar tarefas em um mesmo ambiente com o ser humano. A figura 5 apresenta de maneira macro a sequência das fases a serem realizadas ao longo da fase de concepção.

Figura 5 - Visão geral da sequência de passos da fase de concepção.

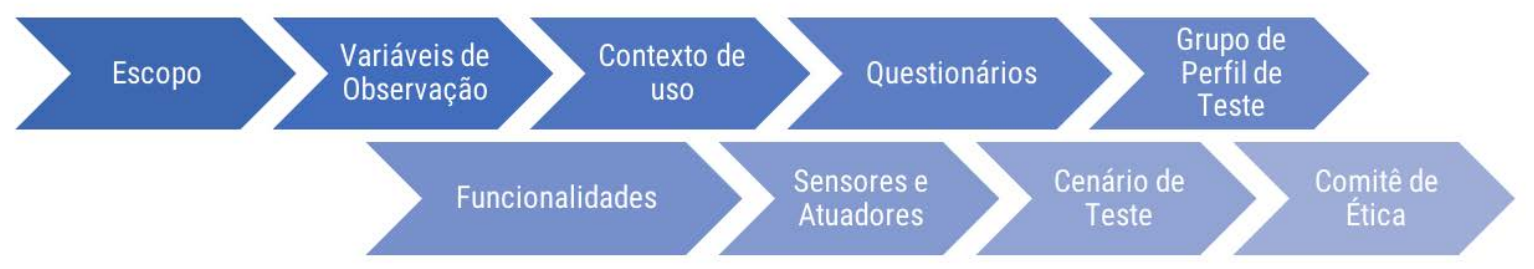

Fonte: o autor.

Na sequência é apresentado em detalhes cada um dos passos necessários para conseguir realizar a fase de concepção do projeto de interação humano-robô. 


\subsubsection{Escopo do Projeto de Interação Humano-Robô}

A definição do escopo do projeto é o passo mais importante da fase de concepção. Esse passo é uma entrada constante para todos os passos do projeto. O escopo é responsável por definir os limites do projeto e também de cada um dos passos e fases que compõem o projeto. O escopo deve ser criado como uma descrição detalhada do projeto. Essa descrição deve conter informações sobre qual o trabalho que será executado para atender o produto ou serviço desejado.

É importante que estejam definidos de uma maneira macro as funcionalidades e funções específicas do projeto. Após as definições realizadas para o projeto, é fundamental que esse escopo seja validado para identificar se os limites estabelecidos são suficientes para avaliar o serviço ou produto desejado. Nessa tese o produto desejado é um projeto de interação entre seres humanos e robôs autônomos dentro de um ambiente doméstico.

\subsubsection{Variáveis de Observação}

As variáveis de observação são importantes para que as informações sejam analisadas dentro do escopo do projeto. Elas auxiliaram a definir quais são os sensores e atuadores necessários para a construção do robô. Essas variáveis devem ser separadas em classes de maneira que seja possível referencia-las como um grupo durante o projeto. As classes definidas nessa tese são etnográficas, comportamentais, do robô e ações na interação, todas discutidas nas seções a seguir. A investigação tem o objetivo de melhorar a interação humano-robô sempre com o foco nas necessidades do ser humano, que é o usuário do sistema. Cada classe de variáveis adotada possuí um conjunto de características e especificidades única para obtenção e análise das informações. Identificar as variáveis é importante, por que auxiliará na definição da maneira de captura de cada uma delas. Por exemplo, a variável nome do usuário, pode ser obtida através da interação por voz com o usuário ou através de questionário prévio aplicado antes da interação e repassado ao robô para interação mais pessoal. O meio de obtenção dependerá do momento e objetivo do projeto.

A escolha do conjunto de variáveis é realizada com base em revisão bibliográfica da literatura da área de interação humano-robô e interação humano-computador. Além disso, conhecimento prévio do especialista também deve ser utilizado para selecionar as variáveis de observação a serem utilizadas no projeto. O objetivo de identificar as variáveis é representar melhor as informações necessárias para análise do problema. Ao longo do capítulo 2, algumas variáveis para projeto de interação de robôs autônomos foram identificadas. Na literatura, o uso da teoria de proximidade demonstra possibilidades de extração de fatores comportamentais que utilizam como base a distância social, neste caso entre pessoas e o robô. Esses fatores não referem-se apenas sobre a posição física entre dois agentes. Questões de comportamento de interação também são contemplados pela teoria de proximidade. Por exemplo, a orientação dos 
ombros e tronco em relação a posição do robô (linguagem corporal) (MEAD; MATARIĆ, Maja J., 2016). A fixação e frequência de olhares pode determinar o início e o fim de uma interação. O olhar também auxilia a determinar quem são os principais indivíduos na interação (MUMM; MUTLU, 2011; SRINIVASAN; HENKEL, Z.; MURPHY, R., 2012). O emprego de reconhecimento de expressões faciais para auxiliar na análise do quanto o cenário com o robô é confortável para o indivíduo, ou seja, o quanto ele aprecia e mantém a interação. Existir uma avaliação em tempo real das reações deste indivíduo durante todo o processo de interação, auxilia na compreensão da experiência do usuário (AMARAL; GIRALDI; THOMAZ, 2014). Outra técnica para análise de conforto na interação é a avaliação da emoção através da voz da pessoa, ou através do uso de equipamento de eletroencefalografia (EEG), porém este último é um método mais invasivo já que exige a adição de um equipamento na pessoa que interage com o robô (BOS et al., 2006; LEE; HSIEH, 2014).

Para que essas variáveis sejam capturadas e analisadas de maneira automatizada, é possível empregar diversos sensores para auxiliar na leitura e quantificação delas. Sensores de

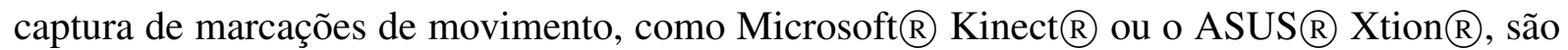
utilizados para quantificar os valores comportamentais obtidos através das variáveis, que envolvem distância entre agentes e orientação de corpos. Para realizar o reconhecimento de expressões faciais utiliza-se uma câmera de vídeo. Pode-se assim executar a leitura da face da pessoa em tempo de interação. As variáveis referentes a questão da fixação dos olhares dos agentes para identificar o início e o fim da interação, podem ser obtidas através de ambos sensores, sendo possível determinar a orientação da cabeça e torso do indivíduo, além de também a direção do olhar da pessoa para o robô. A voz do indivíduo capturada pelo robô permite a análise da emoção na interação. Ela é obtida através de um microfone direcional ou um arranjo de microfones, que amplifica a capacidade de percepção do robô em relação ao ambiente e a pessoa que interage com ele.

As variáveis aplicadas ao comportamento possui dependência do cenário de interação. Entretanto, as informações obtidas com as variáveis etnográficas como idade, experiência computacional, gênero, local de nascimento, etnia, entre outras, são independentes do cenário. Existem alguns algoritmos na área de visão computacional que são capazes de identificar algumas variáveis etnográficas de maneira automática (YANG; AI, 2007; SHAN, 2012; YLIOINAS; HADID; PIETIKAINEN, 2012; SAMADI, 2013; AMARAL; GIRALDI; THOMAZ, 2014). Essa técnica auxilia na construção de mecanismos de tomada de decisão de maneira automática, deixando a interação com o robô mais autônoma e inteligente. Porém, as informações que não podem ser obtidas de maneira automática, então alguns métodos como questionários e entrevistas são necessários para melhor compreensão do perfil do usuário e identificar sua experiência durante a interação.

Nesta tese são apresentados quatro conjuntos de variáveis consideradas como base para projetos de interação humano-robô. Eles são classificados entre: etnográficas, comportamentais, do robô e de ações de interação. As variáveis etnográficas são apresentadas na seção 4.1.2.1. 
Na sequência as variáveis comportamentais na seção 4.1.2.2. Depois, as variáveis do robô são apresentadas na seção 4.1.2.3. E por fim, as variáveis de ações na interação apresentadas na seção 4.1.2.4.

\subsubsection{Variáveis Etnográficas}

As variáveis etnográficas têm o objetivo de coletar informações sobre etnia, cultura, costumes e outros fatores antropológicos (BORGES, 2005). Além dessas informações, elas auxiliam na identificação de dados sobre idade, gênero, experiência social e tecnológica do indivíduo. Todas as informações representadas nos dados etnográficos são relevantes para verificar a adesão do usuário sobre novas tecnologias, em qual cultura ele está inserido, e outras informações que podem determinar o nível de interação que o usuário aceita com a tecnologia, neste caso o robô. Essas informações podem ser capturadas através de questionários e entrevistas. Caso seja uma necessidade do projeto, o robô pode coletar as informações sobre a etnografia da pessoa através de entrevista verbal. Essas informações podem servir para o especialista identificar preferências do usuário importantes na construção do robô ou até para uma interação mais personalizada do robô. A lista apresentada a seguir define um conjunto mínimo de variáveis etnográficas e uma breve explicação sobre o significado de cada uma:

a) Idade: informa a idade do indivíduo.

b) Gênero: informa o sexo biológico do indivíduo.

c) Local de Nascimento: informa qual o local de nascimento do indivíduo. Essa variável auxiliará a determinar a base cultural do indivíduo.

d) Etnia: informa a origem da família do indivíduo. Outra variável que auxilia na determinação da base cultural do indivíduo.

e) Quantidade de Gadgets: informa a quantidade de gadgets que o indivíduo possui, ajudando a identificar qual a experiência e o contato dele com a tecnologia.

f) Contato prévio com Robôs: informa apenas se o indivíduo já possuiu algum contato com robôs. Auxiliará a determinar o contato com a tecnologia, principalmente com robôs que poderá influenciar no seu comportamento durante a interação.

g) Tipos de Robôs: informa quais são os tipos de robôs que o indivíduo teve contato. Os tipos poderão ser robôs Pet, Humanoides, Androides, Móveis, entre outros. Essa variável é um complemento da variável "Contato prévio com Robôs".

h) Quantidade de cidades visitadas: informa a quantidade de cidades que o indivíduo já visitou além da sua cidade natal. É importante para identificar o contato com outros tipos de cultura. Isso poderá influenciar no comportamento definido por sua cultura.

i) Quantidade de cidades que morou: informa a quantidade de cidades que o indivíduo já morou além da sua cidade natal. É importante para identificar a vivência com outros tipos de cultura. Isso poderá influenciar no comportamento definido por sua cultura. 
j) Quantidade de países visitadas: informa a quantidade de países que o indivíduo já visitou além da sua cidade natal. É importante para identificar o contato com outros tipos de cultura. Isso poderá influenciar no comportamento definido por sua cultura.

k) Quantidade de países que morou: informa a quantidade de países que o indivíduo já morou além da sua cidade natal. É importante para identificar a vivência com outros tipos de cultura. Isso poderá influenciar no comportamento definido por sua cultura.

Em diversos trabalhos do capítulo 2, onde a questão cultural do indivíduo é abordada, é discutido sobre a influência que a cultura provê no comportamento do indivíduo. A cultura é tratada como o local de nascimento da pessoa (ERESHA et al., 2013). Entretanto, a questão cultural na vida de uma pessoa é mais abrangente pois, pode ser relacionada com a experiência adquirida ao longo de sua vivência social, como por exemplo, países e cidades que o indivíduo visitou e viveu, o meio ao qual ele está inserido, sua profissão, entre outras informações. Dessa forma, o conjunto de variáveis apresentado na lista acima auxilia a mapear de forma macro a experiência social e de vida do indivíduo. O uso das informações etnográficas tem o objetivo de investigar até que ponto elas podem influenciar na experiência do usuário durante a interação com o robô.

\subsubsection{Variáveis Comportamentais}

Variáveis comportamentais tem como principal objetivo identificar os estímulos do usuário dentro do cenário que contém uma determinada tarefa. As variáveis comportamentais são coletadas a partir de informações encontradas em expressões corporais, faciais, no uso do sistema e na declaração explícita da pessoa ou do robô. O uso de variáveis comportamentais possibilita uma análise baseada em teorias de linguagem corporal e de microexpressões (LAMBERT, 2008). No trabalho apresentado por Lambert (2008) são discutidos os significados de 101 expressões corporais identificadas ao longo de sua pesquisa. O conjunto de variáveis comportamentais apresentados nessa seção podem ser utilizados não apenas para extrair o perfil comportamental do indivíduo, mas também para avaliar a ação realizada pelo robô ao interagir com o usuário. Dependendo do hardware utilizado no robô, essas variáveis também possibilitam que o robô realize a imitação dos comportamentos durante a interação como um aprendizado por observação ou trabalho de espelhamento do comportamento. A lista apresentada a seguir define as variáveis comportamentais obtidas através da literatura estudada nessa tese e uma breve explicação sobre o objetivo de cada uma das variáveis:

a) Expressões Faciais: é possível identificar se a reação do indivíduo foi positiva ou negativa, a partir de uma ação do robô. Existem seis expressões bases que combinadas formam diversas outras (JIANG et al., 2014). É sugerido por este trabalho considerar apenas as seis expressões bases (raiva, nojo, medo, feliz, triste 
e surpreso (SONG; CHEN, 2011)), classificadas em dois grupos: expressões faciais positivas e expressões faciais negativas. O intuito dessa variável é realizar a avaliação da ação do robô com base nas expressões faciais do indivíduo. Caso identifique a necessidade dentro do cenário de atuação, o detalhe desta variável pode tornar-se interessante. As percepções são feitas pelo especialista durante o experimento ou implementado no robô com o uso de bibliotecas de visão computacional, algoritmos de classificação e o uso de uma câmera para obter a imagem.

b) Tempo de Aproximação: identificar o tempo que o robô levou para se aproximar do indivíduo sem gerar situações de desconforto, como por exemplo, afastar-se do robô, expressar alguma face negativa, ou posições do corpo que repassem uma imagem negativa, como braços cruzados e tronco inclinado levemente para trás.

c) Orientação do Olhar ao Robô: identificar a orientação do olhar que indivíduo mantém ao robô, sendo possível saber se a interação está continua ou não. Isso pode influenciar se o robô está interagindo de maneira confortável ao indivíduo ou se esse está incomodado com a presença do robô.

d) Tempo do Olhar: é possível mensurar o interesse do indivíduo durante a interação através do tempo que ele permanece com o olhar fixo no robô. Quanto maior o tempo do olhar, maior o interesse na interação do indivíduo.

e) Orientação dos ombros: Auxilia a mensurar o interesse do indivíduo durante a interação. Ao analisar se os ombros possuem a mesma orientação que a cabeça e também uma orientação em direção ao indivíduo que interage com o robô é possível inferir seu objetivo e interesse pela interação. Além disso, é possível determinar através do alinhamento do quadril com o ombro do indivíduo o ângulo de inclinação de seu torso. A inclinação do torso auxilia a identificar quanto o indivíduo está interessado na interação, para isso basta verificar se ele está inclinado em direção ao robô para determinar um interesse positivo (LAMBERT, 2008).

f) Orientação do quadril: Auxilia a mensurar o interesse do indivíduo durante a interação. A orientação do quadril em direção ao robô ou na direção oposta auxilia a determinar o grau de interesse do indivíduo na interação. Quando mais alinhado à direção do robô, maior o interesse do indivíduo na interação (LAMBERT, 2008). Essa variável pode ser trabalhada em conjunto a orientação dos ombros.

g) Estilo da Voz: é importante, pois pode determinar a reação que o indivíduo terá após a interação via áudio com o robô. Além disso, é possível determinar se o indivíduo está confortável ou não durante a interação, analisando o tom de sua voz ao responder o robô. A análise de emoção através de áudio é uma tarefa complexa e deve ser considerada para robôs de serviço que irão atuar em ambientes domésticos.

h) Conforto: determina se o indivíduo está disposto a continuar a interação ou se algo o incomoda, fazendo com que desista de interagir com o outro agente. Essa 
é uma informação que pode ser obtida através das demais apresentadas acima ou de forma declarada diretamente pelo usuário por voz.

i) Medo: determina se o indivíduo sente-se seguro durante a interação com o robô. Pode impactar diretamente a experiência de interação do usuário. Essa é uma informação que pode ser obtida através das demais apresentadas acima ou declarada diretamente pelo usuário por voz.

As variáveis apresentadas acima podem auxiliar na descoberta do interesse em relação a interação, além de sua apreciação. Algumas delas, como as que envolve o olhar, podem necessitar de equipamentos mais específicos para obter uma melhor acurácia na captura. Outras variáveis necessitam de técnicas e estudos direcionados para trazer a interação à um nível mais natural, como o caso da voz. Dessa forma, escolher quais variáveis trabalhar influencia não só sobre o estudo realizado, como também nos equipamentos embarcados no robô. Tais equipamentos, podem influenciar em sua aparência e consequentemente na experiência do usuário.

\subsubsection{Variáveis do Rob̂}

Além das variáveis referentes a etnografia e comportamento, deve-se considerar também as informações sobre o robô uma vez que sua aparência pode influenciar na reação e expectativa das pessoas durante a interação (HEGEL; LOHSE, M.; WREDE, 2009). Variáveis do robô podem auxiliar a identificar quais são os principais fatores de sua aparência que tornam a interação humano-robô uma boa experiência ao usuário. Também pode-se investigar a naturalidade permitida pelo hardware utilizado em sua construção. Um conjunto de variáveis é apresentado com o objetivo de caracterizar fatores do robô, referente a sua aparência, que influenciam na interação social. Esse conjunto de variáveis é apresentado a seguir:

a) Altura: A altura do robô para identificar a influência da diferença entre alturas de robôs e humanos.

b) Volume: O volume ocupado pelo robô pode influenciar no conforto da interação, uma vez que quando o robô atingir uma zona social mais próxima do indivíduo pode causar uma sensação claustrofóbica a ele.

c) Tipo do Robô: Segundo Choi, Kim e Kwak (2014), robôs possuem dois tipos: Autônomos e Tele-operados. Essa variável define o quanto de intervenção humana é necessário para que o robô possa executar a tarefa objetivo.

d) Classificação do Robô: Segundo Dobra (2014) classificar um robô é uma tarefa muito complexa e pode envolver diversas variáveis. Dessa forma, para essa tese será considerado uma classificação mais simples. O robô deve ser classificado como: fixo, móvel com rodas, móvel bípede, móvel quadrupede, móvel com manipuladores. Outras classificações podem ser inseridas conforme a necessidade e inclusão de novos robôs. 
e) Aparência Física: Essa variável descreve se o robô possui uma aparência amigável ou agressiva. Essa variável depende da preferência do usuário, mas a parte do formato físico do robô pode influenciar na percepção desta variável.

f) Nível de Ruído: Determina qual o nível de ruído que os atuadores e sensores do robô podem gerar de tal forma, que possa influenciar na interação humano-robô. Como exemplo, pode-se citar o Big Dog ${ }^{1}$, da Darpa Robotics, que é movido através de um motor diesel e seus atuadores pneumáticos e hidráulicos apresentam um alto grau de ruído.

\subsubsection{Variáveis de Ações na Interação}

Existem variáveis que determinam as possíveis ações que o robô e o ser humano podem executar, uma vez que o robô é o elemento ativo durante o experimento. Essas ações podem gerar comportamentos diferentes de acordo com o contexto ao qual o cenário está inserido. No caso do robô, as possíveis ações são determinadas a partir do hardware disponível para o projeto. Fatores como tipo de manipulador, sonorização, saída de vídeo, entre outros, determinam quais são as ações que habilitem o robô executar. As variáveis que compõem as informações das possíveis ações que o robô pode executar são:

a) Aproximação: Forma de aproximação do robô ao indivíduo. Pode ser classificada entre rápida, devagar, brusca ou suave.

b) Movimentação do Manipulador: Caso exista um manipulador deve descrever como é feita a movimentação do manipulador em direção ao usuário. A classificação pode ser feita entre brusca e suave; ou em relação a sua amplitude, como longo e curto.

c) Estilo de Voz: Ao emitir algum tipo de som o robô deverá manter um estilo de voz para que seja possível simbolizar qual o tipo de mensagem ele deseja falar. A classificação será feita de maneira simplificada, considerando apenas se é um estilo educado ou agressivo.

d) Volume de Voz: Ao emitir um som, o robô deve saber qual o volume adequada considerando a interação, ambiente e distância do segundo agente. Uma classificação simples pode ser utilizada, como por exemplo, alto e baixo.

e) Expressão Facial: Ao iniciar o contato visual com o indivíduo, pode ocorrer diversas expressões do robô na tentativa de manter o conforto do indivíduo durante o processo de interação. Simplificando as expressões são consideradas apenas dois tipos de expressões realizadas pelo robô: amistoso e não-amistoso. As expressões faciais do robô poderão ser executadas através de um tablet acoplado nele.

A partir das variáveis identificadas, deve-se realizar a definição do contexto de uso para definir quais e como são utilizadas cada uma das variáveis no projeto de interação humano-

\footnotetext{
${ }^{1}$ http://www.bostondynamics.com/robot_bigdog.html
} 
robô proposto. Elas devem ser necessárias para atender os objetivos de interação apresentados a partir do contexto de uso. O contexto de uso é detalhado na seção 4.1.3

\subsubsection{Contexto de Uso}

O contexto de uso possui influência direta na interação das pessoas com os sistemas interativos. Dependendo do contexto, cada pessoa irá agir de acordo com a influência de sua cultura, sociedade e outras questões externas. Uma pessoa executa as tarefas de maneira única com modos desenvolvidos ao longo de sua vida, baseando-se na educação obtida através de sua família. Essa base exerce força sobre os conhecimentos prévios, concepções e linguagens utilizadas durante o processo de interação. O contexto de uso utilizado para análise dos usuários no processo de interação é diferente do contexto aplicado ao cenário de desenvolvimento em geral. Para desenvolvedores o contexto é apenas os limites de aplicação do projeto. O contexto de uso apresentado nessa seção, tem relação com o ambiente de aplicação do produto e o local onde o usuário consumirá esse sistema.

É importante dar ao contexto de uso um ambiente natural ao usuário, um local onde ele faria o uso, de maneira real, do sistema. Isso influencia diretamente o tipo de análise que deve ser realizado. Além de auxiliar diretamente nas diretrizes de construção e consequentemente na análise dos resultados obtidos durante os testes. A definição do contexto de uso é baseada em um texto descritivo que delimita todo o cenário da aplicação e como foi planejado o experimento. Esse cenário descreve quem é o usuário, quais os pontos de interação com o sistema, como será o comportamento do usuário e do robô. O contexto descrito delimita todo o escopo do teste. Ele assegura que as observações tenham o objetivo de garantir a qualidade do uso dentro do ambiente investigado.

\subsubsection{Questionários}

Questionários são formulários que podem ser impressos ou construídos em sistemas que utilizem a internet. Neles são realizados uma coleta de informações sobre o que o usuário, participante do teste, sente ou pensa em relação ao produto em análise. Esse formulário é composto por perguntas que podem ter características que a deixem fechadas ou abertas. No caso de questionários a recomendação é forte para perguntas fechadas por proporcionarem uma análise mais fácil e também serem mais rápidas para responder.

Esse meio de coleta de informações tem uma vantagem perante a outros métodos como percurso cognitivo, entrevistas e grupos focais. Nele a distribuição pode ser realizada a pessoas que estejam geograficamente dispersas, fazendo com que elas possam responder a qualquer horário e em qualquer lugar. No caso dos projetos de interação humano-robô, essa distribuição geográfica não é interessante, pois existe a necessidade de realizar o teste de interação com o robô, posteriormente, a fim de validar o experimento social com o robô após um teste presencial. 
Para preencher o questionário, cada pessoa desprende de um certo tempo para responder as perguntas contidas nele. Esse tempo deve ser respeitado e ainda é importante que a pessoa encontre-se em um ambiente confortável para que ele se sinta a vontade ao respondê-lo. No caso dos testes realizados com interação humano-robô, recomenda-se que utilize esse tempo de resposta para preparar o início do teste com o robô. Essa preparação consiste em liberá-lo da energia elétrica, acertar a captura de dados dos sensores e também preparar o mecanismo de controle e tomada de decisão com o robô. Toda essa preparação deve ser realizada em um ambiente separado ao do preenchimento do questionário para não distrair o participante do teste.

A comunicação com o participante durante esse período é restrita, devendo ser mínima, de preferência nula. É importante que isso se mantenha, para que evite tendências nas respostas influências pela opinião e conversa do especialista. Dessa maneira, cada pergunta deve ser realizada de forma a ter um fácil entendimento. Deve-se evitar ambiguidades e mal-entendimentos. Uma boa prática para essa situação é envolver uma pessoa que não participou da criação do questionário e solicitar que ela leia as perguntas em voz alta, dizendo o que entendeu sobre cada uma delas. Assim, é possível validar a falta de ambiguidades e mal-entendimentos.

Ao estruturar um questionário é importante coletar informações demográficas básicas, como gênero e idade, além de informações sobre a experiência da vida do usuário, a tecnológica e também a experiência prévia sobre o produto que irá interagir, no caso o robô. Outras informações importantes são as declaradas sobre a experiência com a interação realizada durante o teste com o robô. No caso da interação entre o usuário e o robô, recomenda-se separar as informações mencionadas entre dois questionários, um de pré e outro de pós teste de interação. No questionário pré teste inclui-se as perguntas referentes as informações demográficas básicas e experiências prévias de vida, tecnológica e com o produto. É importante também existir uma informação que possa vincular os registros de respostas entre o pré e o pós questionário.

No questionário pós teste encontram-se as perguntas referentes a experiência de interação com o produto, no caso o robô, contendo informações essenciais à análise do produto. $\mathrm{O}$ tipo de resposta escolhida para cada pergunta irá influenciar no tipo de análise realizada mais a frente. Respostas fechadas que utilizem escalas de Likert, múltiplas escolhas ou por faixa de valores, auxiliam em análises quantitativas. Já as respostas abertas, de texto corrido, permitem uma análise qualitativa, pois é necessária sua leitura por um especialista para que ele consiga interpretar as informações que são relevantes ao processo de análise. Esse ponto será abordado mais na seção 4.4 apresentada mais a frente neste capítulo.

\subsubsection{Seleção do Grupo de Perfis de Teste}

Nessa etapa é analisado as características mais importantes dos usuários que irão compor o grupo de teste. É uma tarefa que deve ser realizada com muita atenção, pois aqui é selecionado o público alvo do projeto de interação humano-robô. Aqui são estimados os intervalos que irão compor a idade dos usuários. Quais são as principais características e conhecimentos sobre a 
tecnologia aplicada durante o teste. Todas essas informações são importantes para determinar as diretrizes que o projeto irá seguir e como será validado e publicado as informações. Essa seleção faz parte da estratégia que o projeto irá seguir em sua construção e qual o foco que será dado a criação da aparência do robô.

O principal intuito da seleção de grupo de perfis de teste é estipular uma amostra mais próxima da realidade ao seu perfil real de consumidores do produto. Para a seleção deve-se pensar em quais atividades esses usuários irão realizar com o robô e como eles podem se envolver nos testes. Para cada um desses usuários deverá ser apresentado um termo de consentimento e esclarecido quais são os objetivos do teste. Informar se existe ou não o risco de se machucar durante o teste, pois nesse caso o robô pode acabar realizando alguma ação não prevista devido sua autonomia e até mesmo ruídos na leitura do sensor.

Questões de bonificações deverão ser pensadas nessa etapa, pois isso pode trazer outros fatores ao teste, como interesse apenas na remuneração. Recomenda-se que os testes sejam executados de maneira voluntária evitando qualquer tipo de questionamento ao real intuito do resultado. Esse é um fator que impacta diretamente na seleção do perfil, pois deverá ser previsto um perfil que esteja mais voltado a ajuda real dos testes realizados. A seleção é importante, pois é um dos passos fundamentais para a construção de um projeto apoiado pelo comitê de ética, que será discutido em mais detalhes na seção 4.1.9.

\subsubsection{Funcionalidades}

Realizar uma boa especificação de projeto de software é importante para o seu sucesso. Projetos sem especificações são difíceis de serem reproduzidos, uma vez que os robôs utilizados são bem específicos. Além de serem específicos, os robôs utilizados são construídos, nos laboratórios das universidades e centros de pesquisas, em parte das pesquisas. Outras pesquisas utilizam robôs como: Softbank NAO ${ }^{2}$ e PR2 ${ }^{3}$. Eles são produzidos por empresas especializadas fazendo com que o projeto fique restrito a capacidade determinada pela fábrica.

Em engenharia de software são estudados vários métodos que auxiliam na especificação do projeto. Nesses métodos são encontrados a contemplação de alguns princípios que garantem a reprodução, manutenção e evolução do projeto ao longo tempo. Os princípios de engenharia de software não são vistos como regras, mas como boas práticas para o desenvolvimento do projeto (WAZLAWICK, 2013). As boas práticas aplicadas em sistemas computacionais, também podem ser aplicadas no desenvolvimento de projetos de robôs. Em seu trabalho Wazlawick (2013) apresenta algumas boas práticas que a engenharia de software provê aos projetos. A lista a seguir, descreve as boas práticas que contribuem para a evolução e formalização do projeto dessa tese:

\footnotetext{
${ }^{2}$ https://www.ald.softbankrobotics.com/en/robots/nao

${ }^{3}$ http://www.willowgarage.com/pages/pr2/overview
} 
a) Decomposição: é a criação de um software ou produto a partir de um conjunto funcional de alto nível, os requisitos do projeto, onde esses são divididos em partes mais simples até chegar a um produto atômico, ou seja, partes de códigos. No robô, pode-se incluir também como os sensores e atuadores do projeto.

b) Padronização: são importantes pois, através dos padrões conhecimentos adquiridos em projetos passados podem ser aplicados nos atuais evitando assim, que erros similares sejam cometidos.

c) Flexibilização: auxilia na acomodação das mudanças de requisitos do projeto, No caso de robótica, nos cenários de atuação, diferentes contextos de uso, novos sensores e plataformas, entre outros.

d) Desenvolvimento Iterativo: a cada momento novas necessidades são criadas e a partir da criação deve ser inserida no projeto. Nas metodologias iterativas, cada ciclo de desenvolvimento é independente e deve entregar um produto operacional. Ao tratar de um projeto de interação humano-robô, pode-se dizer que o processo iterativo é longo e não necessariamente finito. Isso ocorre devido as novas necessidades dentre os diversos contextos de uso como hospitais, casas, hotéis, museus, resgate, shoppings, entre outros.

e) Arquiteturas baseadas em Componentes: auxilia a lidar com complexidade do projeto e também o reuso e expansão. Cada sensor novo inserido no robô deve ser inserido junto a um novo módulo que captura as informações, consome os dados e entrega as informações para os componentes de tomada de decisão do robô, por exemplo.

Para garantir que as boas práticas sejam aplicadas no projeto, é necessário o uso de algumas ferramentas utilizadas dentro processo de criação de software, aqui nessa tese utilizada na criação do projeto de interação humano-robô. O primeiro passo é definir as funcionalidades do sistema, que representam as ações que o robô pode executar. Para criação das funcionalidades do robô utiliza-se as informações obtidas através do contexto de uso (vide seção 4.1.3), das variáveis de observação selecionadas (vide seção 4.1.2) e dos perfis de teste (vide seção 4.1.5). As variáveis de observação são selecionadas e em conjunto com o contexto de uso, deve-se iniciar um processo de brainstroming para identificar os requisitos funcionais que estão contidos nas funcionalidades. A determinação do escopo é muito importante para identificar quais são as tarefas que o robô realizará durante a interação social com o ser humano.

Nesse momento, é uma boa prática revisitar a definição do escopo do projeto para realizar uma análise mais profunda sobre as funcionalidades que tem potencial para serem contemplas. Em algum momento do projeto, pode ocorrer algum problema externo, como a quebra de um sensor fundamental para aquela funcionalidade, e não conseguir cumprir com o planejado. Por isso, é importante determinar as funcionalidades potenciais, a fim de identificar o melhor caso de resultado do projeto. Cada funcionalidade deve ser capaz de atender um requisito do 
projeto, e deve ser planejada no momento da construção do projeto. Depois é revisado os sensores e atuadores que contribuem com o escopo para cada funcionalidade, vide a seção 4.1.7.

\subsubsection{Sensores e Atuadores}

Com as funcionalidades especificadas, o próximo passo é definir quais são os sensores e atuadores as atendem. Cada sensor deve ser pensado de maneira que ele possa coletar as informações necessárias para análise e tomada de decisão do robô perante a funcionalidade que ele deve possuir. Esse conjunto irá determinar a posição que o sensor deve ser adicionado no robô. Além dos sensores, é importante que os atuadores sejam adicionados para contribuir com a execução das tarefas de interação. Os atuadores fazem o robô se locomover, interagir e manipular com o cenário ou usuário. Eles também podem auxiliar no posicionamento adequado dos sensores. A combinação dos sensores com os atuadores deixa a tarefa mais dinâmica e flexível. Eles são importantes também possam tornar as interações cada vez mais naturais. Por isso, é importante que cada um desses componentes deve ser escolhido de acordo com as funcionalidades.

\subsubsection{Cenário de Teste}

O cenário de teste é responsável por descrever as situações de uso existentes dentro de uma determinada tarefa. Como essa tarefa está inserida dentro do contexto de uso, a criação desse cenário deve ser realizada quase como uma transcrição dele. Sua descrição deve ser realizada mais detalhada contendo algumas possibilidades dentre as situações. É importante que a sua descrição gere uma motivação para que o teste ocorra ao mesmo tempo que sua avaliação de sucesso seja feita de maneira simples. Um ponto importante ao definir-se cenários de teste é a possibilidade de testar diversas funcionalidades em um único cenário.

Caso exista mais do que um cenário isso auxilia na construção de um sistema de teste mais robusto, que irá validar as funcionalidades do sistema em diversos níveis. Além do descritivo, é importante, no cenário de teste para projeto de interação humano-robô, pensar na posição do ser humano dentro do ambiente de teste. Este, por sinal, também deve ser descrito de maneira a atender todas as possibilidades contempladas nos cenários de teste. Agora, com todos esses passos de planejamento, concepção do projeto, pode-se realizar a confecção do projeto para envio ao comitê de ética, tratado na seção 4.1.9. A aprovação do comitê de ética é importante, pois todo teste envolve o ser humano e pode ocorrer algum incidente. Essa aprovação auxilia na validação de um produto que não seja prejudicial ao ser humano. 


\subsubsection{Projeto ao Comitê de Ética}

Todos os passos anteriores, contém informações importantes para a construção do projeto ao comitê de ética brasileiro. Na criação do projeto é importante identificar diversos pontos que devam mitigar qualquer problema ao usuário, participante do teste. Um modelo para a criação do projeto ao comitê de ética brasileiro, recomendado por essa tese, mantém a seguinte estrutura:

a) Introdução: apresentação das metodologias, motivações e justificativas sobre o projeto;

b) Objetivos: guiam a construção do seu projeto e ajudam a avaliar o sucesso da tarefa.

c) Hipóteses: descreve o que deve ser validado após a execução dos testes.

d) Benefícios: descreve quais são os ganhos ao ter o produto no mercado, inclusive os pontos positivos para a sociedade em geral.

e) Metodologia: descreve a metodologia utilizada para construção do produto e principalmente para execução dos testes a serem realizados.

- Sujeito de Teste: descrição dos perfis de teste (seção 4.1.5).

- Procedimentos Experimentais: descrição dos cenários de teste (seção 4.1.5).

- Dados Experimentais Coletados: descrever o que será coletado durante os testes.

- Processamento e Análise dos Dados Coletados: descreve como será realizado as avaliações dos testes e como serão processadas essas informações.

f) Riscos: quais são os riscos para o sujeito de teste ao participar do experimento.

g) Desfecho Primário: qual é a intenção do teste, como um objetivo descrito de maneira mais simples.

h) Cronograma de Execução: cronograma do planejamento do trabalho.

i) Financiamento: detalhes sobre custo do projeto, equipamentos e quem é o principal patrocinador. Esse é um item importante para fiscalização financeira, caso exista necessidade no futuro, principalmente perante ao cenário atual do Brasil.

j) Equipe Executora: quem são os membros da equipe e quais são seus respectivos papéis.

O projeto dever ser submetido a avaliação do comitê de ética através da Plataforma Brasil $^{4}$, que está ligada ao ministério da saúde do Governo Brasileiro. Esse processo demora em torno de 90 dias, portanto deve estar na fase de concepção do projeto. Ao escrevê-lo deve-se pensar na evolução do projeto, para que seja contemplado alguns ciclos da iteração do projeto, pelo menos. Caso não seja feito dessa maneira, durante a fase de análise será necessário a submissão de um novo projeto, para cada ciclo de evolução do projeto.

\footnotetext{
${ }^{4}$ http://plataformabrasil.saude.gov.br/login.jsf
} 


\subsection{CONSTRUÇÃO DO PROJETO DE INTERAÇÃO HUMANO-ROBÔ}

Essa seção apresentada os detalhes que devem ser contemplados na fase de construção do projeto de interação humano-robô, utilizando robôs autônomos. Esse é uma etapa que contempla definições de arquitetura, projeto mecânico e de software para sequência da metodologia proposta. Nessa etapa testes pilotos são executados para auxiliar na definição do perfil do usuário, para análise automática do robô. Toda a metodologia para criação desse perfil é contemplado nessa etapa do projeto. O foco do projeto é sempre realizar uma construção do robô centrado no usuário. A figura 6 apresenta de maneira macro a sequência dos passos contidos dentro da fase de construção.

Figura 6 - Visão geral da sequência de passos da fase de construção.

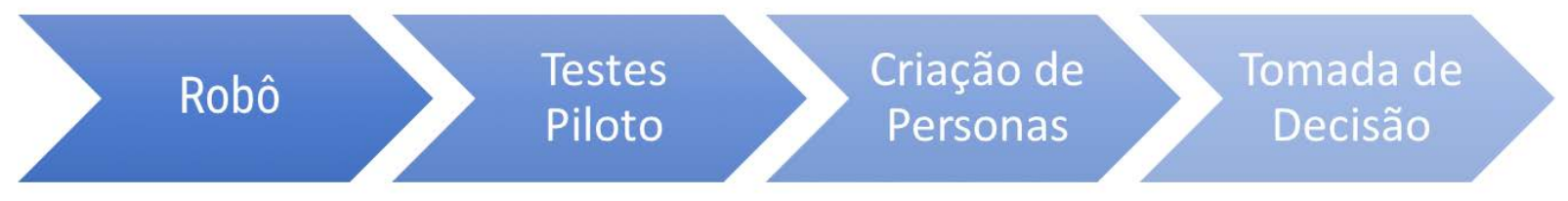

Fonte: o autor.

Na sequência é apresentado em detalhes cada um dos passos necessários para conseguir realizar a fase de construção do projeto de interação humano-robô.

\subsubsection{Robô}

Essa etapa é dividida em duas partes que devem ser consideradas no projeto. A primeira parte é o projeto mecânico do robô e o segundo o projeto de software dele. Cada particularidade das divisões feitas são discutidas a seguir, nas seções subsequentes.

\subsubsection{Projeto Mecânico}

Com as funcionalidades, sensores e atuadores definidos na fase anterior, é necessário identificar como será a construção física do robô. Será mais vantajoso comprar um produto de prateleira encontrado no mercado, realizar uma modificação nesse produto ou construir um projeto totalmente novo. Aqui é uma etapa que a aparência é importante, mas acima de tudo o projeto deve atender o mínimo de questões de segurança. Recomenda-se realizar protótipos de peças com o uso de impressora 3D. Dependendo da construção e da quantidade de peso que será necessário carregar uma versão final utilizando a impressora 3D pode ser mantida. Caso o material da impressão seja menos resistente, outras opções são possíveis, como fibra de carbono ou alumínio. A questão sobre o material a utilizar é a relação de peso e autonomia de bateria que isso ocorre. É sempre bom pensar no material mais resistente pelo menor pesos, isso acarretará 
em uma autonomia de bateria maior. O projeto mecânico deve levar essas informações em consideração, pois caso contrário a autonomia de robô é mínima.

\subsubsection{Projeto de Software}

Nessa etapa que deve ser considerado todas as questões de inteligência e controle do robô. Alinhar as informações dos sensores para que os atuadores contemplem com precisão o trabalho designado a isso. Nessa etapa, além dos algoritmos de controle que devem ser construídos pensando em cada atuador, é importante identificar a arquitetura do software utilizado. O ideal é trabalhar com um modelo de arquitetura em camadas. Cada camada deve conter uma única responsabilidade evitando assim trabalho dobrado dentro das questões de software do projeto de interação humano-robô.

Junto com a arquitetura é definido também quais são as bibliotecas que serão utilizadas no controle, tomada de decisão e auto teste do robô. $\mathrm{O}$ uso de bibliotecas pode auxiliar a direcionar todo o esforço para criação de algoritmos e técnicas que não foram consideradas em seu trabalho, ou seja, as novas técnicas. Também é importante para utilizar quando o algoritmo já implementado nas bibliotecas não atendem por completo suas necessidades. Nesse ponto é preciso reutilizar uma parte do código para desenvolver uma versão personalizada da biblioteca escolhida. Para robô que contemple computadores de pessoais como seu cérebro, utilizar o ROS (Robot Operating System) para realizar o desenvolvimento do software. Ele mantém a arquitetura em camadas e pode facilitar o trabalho de plug ' $n$ play dos componentes mecânicos e eletrônicos do robô. Além disso, grande parte dos robôs de prateleira do mercado utilizam o ROS como seu sistema principal.

\subsubsection{Testes Piloto}

Com o robô construído é importante que seja realizado o teste piloto. Para o teste, toda documentação e artefatos a serem consumidos, devem estar prontos, inclusive a aprovação do projeto no comitê de ética. Em um projeto tradicional, executar apenas um teste piloto, é necessário para que valide os artefatos a serem produzidos e também do cenário de teste. Entretanto, esse não é um projeto tradicional. Nesse momento é importante que ocorram uma bateria de testes pilotos, para levantar informações dos perfis dos usuários alvo do projeto. A partir desses perfis, serão levantadas informações sobre cada característica marcante dos perfis, agrupados os perfis similares e com esses agrupamentos serão produzidos Personas para auxiliar na adaptação do comportamento do robô perante o usuário.

Os testes pilotos devem ser executados com uma diversidade de perfis para que as Personas produzidas consigam contemplar um grande intervalo de perfis no mundo real. Quanto maior a diversidade, maior será a qualidade das Personas produzidas, pois elas possuirão características bem diferentes entre si. Não existe um número para dizer quantos testes são suficien- 
tes, alguns estatísticos recomendam um número de 30 testes, porém nesse caso seria necessário um número de 30 perfis de cada tipo para atender essa recomendação. Porém, a recomendação sobre o que não se deve fazer é utilizar menos do que 10 testes, pois com esse número o resultado não é robusto, uma vez que ele corre o risco de ficar tendencioso a um único perfil.

\subsubsection{Criação das Personas}

O primeiro passo é resgatar as informações dos questionários respondidos e consolidar em uma única base de dados. Essa base pode ser um sistema relacional, não relacional e até mesmo um arquivo do tipo CSV (Comma-Separated Values). A recomendação é de uso do arquivo CSV, pois é o mais simples de ser manipulado nesse caso. O uso do arquivo, deve-se contemplar com sendo cada linha um perfil de usuário que realizou o teste.

A partir da base de dados criada com as informações dos questionários, deve-se remover as informações de texto livre, uma vez que o algoritmo não possui um interpretador semântico. Sem o interpretador semântico, não é possível criar um modelo quantitativo para as respostas, onde exista uma significância comparativa.

As informações existentes nos questionários podem ser quantificadas, por exemplo a idade do usuário. A comparação de similaridade entre duas idades pode ocorrer com medidas de distância, por exemplo, a distância euclidiana. Outras medidas também podem ser aplicadas, porém dependerá do tipo de informação e necessidade do projeto (MASIERO et al., 2011; MASIERO, 2013). No caso do agrupamento de perfis desta tese, para informações numéricas, a distância euclidiana é adotada. Ela atende a necessidade do algoritmo e do processo para agrupamento dos perfis.

Variáveis categóricas, ou seja, as variáveis que possuem um valor textual que podem ser separadas em categorias, deve-se realizar um tratamento para quantificá-las. Existem duas opções para quantificar as variáveis categóricas. A primeira opção é inserir um código numérico para cada valor, por exemplo, os valores "Celular, Computador, Tablet, Autoatendimento, Caixa Físico" recebem um valor representado por um número inteiro cada ficando "Celular = 1 , Computador $=2$, Tablet $=3$, Autoatendimento $=4$, Caixa Físico $=5$ ”, conforme Masiero (2013). A segunda opção é transformá-las em variáveis dummies ${ }^{5}$. O método dummies transforma cada opção de resposta ou cada categoria em uma nova variável binária onde o valor 1 é para quando a opção for verdadeira e 0 para o oposto.

Realizado os procedimentos para quantificar todas as variáveis, a base de dados já pode ser inserida no algoritmo para o processo de agrupamento. Porém, um outro detalhe nos dados é importante para evitar o problema de tendência no algoritmo. Cada variável possui uma escala diferente. Essa diferença na escala das variáveis pode gerar as tendências no resultado do algoritmo. Assim, é necessário padronizar os valores numéricos existentes na base dentro da mesma escala. Para realizar a padronização dos dados o processo de normalização é executado.

\footnotetext{
${ }^{5}$ http://pandas.pydata.org/
} 
A normalização mais comum a ser feita é manter os valores das variáveis entre 0 e 1 (LATTIN; CARROL; GREEN, 2011). A equação 1 apresenta a forma mais simples de realizar o processo de normalização dos dados. É feita a divisão do valor da característica pelo valor máximo encontrado entre a característica analisada.

$$
X_{i_{\text {normalizado }}}=\frac{X_{i}}{\max _{X_{i}}}
$$

Entretanto, o uso da equação 1 para normalizar os dados, pode gerar também uma tendência ou generalização da normalização. Pode existir uma concentração dos dados em um determinado intervalo generalizando a informação coletada (MASIERO, 2013; MASIERO; TONIDANDEL; AQUINO JUNIOR, 2013; MASIERO et al., 2013). Para evitar o problema da concentração dos dados, utiliza-se a equação 2 como método mais efetivo na normalização dos dados.

$$
X_{i_{\text {normalizado }}}=\frac{X_{i}-\min _{X_{i}}}{\max _{X_{i}}-\min _{X_{i}}}
$$

Após o processo de normalização, as escalas da base estão com uma distribuição uniforme e prontas para serem consumidas pelo algoritmo. O processo de normalização é executado internamente no algoritmo, para evitar esse tipo de problema no agrupamento.

Com as informações normalizadas, o próximo passo é executar o algoritmo de agrupamento QG-SIM. A implementação do algoritmo pode ser encontrada no endereço https : //github.com/amasiero/qgsim. O algoritmo solicita um parâmetro de entrada para auxiliar na construção dos grupos. Esse parâmetro é chamado de valor de similaridade. O valor de similaridade atende um intervalo de 0.0 até 1.0 , sendo 0.0 sem similaridade e $1.0 \mathrm{com}$ total similaridade. O nome dado a esse parâmetro é valor Q. O valor $\mathrm{Q}$ determina quais perfis pertencerão ao mesmo grupo (MASIERO, 2013).

O QG-SIM tem um diferencial dos demais algoritmos que auxilia na construção de Personas. Ao realizar o processo de agrupamento, o QG-SIM garante que a similaridade mínima entre todos os elementos do grupo é igual ao informado no valor Q. Esse comportamento garante uma homogeneidade entre os perfis agrupados, auxiliando no alcance das Personas construídas ao maior número de pessoas (MASIERO, 2013; MASIERO; TONIDANDEL; AQUINO JUNIOR, 2013).

Assim que os grupos são definidos, utiliza-se medidas de tendência central para obter um valor comum para cada variável do grupo utilizada pelo QG-SIM durante o processo de agrupamento. As medidas de dispersão mais comuns são: média, mediana e moda. A aplicação de cada uma depende do tipo de informação que contém nas variáveis da base de dados. Informações numéricas, por exemplo, podem ser utilizadas medidas como a média ou a mediana. Para dados categóricos, o mais indicado é que utilizem a medida de tendência central moda, pois ela identifica o valor pela opção mais frequente nas respostas (MASIERO et al., 2011; MASIERO; TONIDANDEL; AQUINO JUNIOR, 2013; MASIERO et al., 2013). 
Os valores obtidos em cada uma das variáveis auxiliam no processo de construção da Persona. Elas são responsáveis pela definição das informações demográficas como idade, gênero, e outras informações que caracterizam o perfil. Nesse momento, as características que constroem as Personas estão definidas. O próximo passo é construir a descrição da Persona, informar seus comportamentos e experiências de vida. Para isso, utiliza-se as informações de texto livres preenchidas nos questionários. São realizadas análises sobre as respostas e identifica-se os pontos em comum entre os perfis que compõem o grupo. Os pontos em comum são utilizados como base para construir a história da Persona. A história da Persona deve trazer características importantes ao modo como ela interage com o sistema, no caso o robô. As Personas são importantes, pois garantem que uma ampla quantidade de perfis seja contemplada em cada uma delas. Elas auxiliam na generalização dos processos para definir as interações entre os perfis. A partir deste ponto, é importante utilizar essas informações no mecanismo de tomada de decisão do robô. Dessa maneira, o comportamento do robô levará em conta o perfil do usuário durante a tomada de decisão.

\subsubsection{Tomada de Decisão}

Nessa etapa do projeto deve ser construído um mecanismo que o robô possa utilizar para fazer uso ao racionar durante a interação. Os mecanismos de tomada de decisão são técnicas da área de inteligência artificial e aprendizado de máquina encontrados na literatura. A tomada de decisão, ao longo do ciclo de evolução do projeto, deverá ser composto por diversos algoritmos com objetivos distintos e bem segmentados. O primeiro algoritmo recomendado é um que consiga realizar a classificação do perfil do usuário através da Persona. Alguns dos classificadores que podem ser utilizados nessa etapa do projeto são: K-Nearest Neighbor (KNN), Support Vector Machine (SVM), rede Bayesiana, Naïve Bayes, Rede Neurais, entre outros. Na sequência, com a Persona definida, identificar, de acordo com a tarefa, qual a maneira de interagir com a Persona. Quais ações tomar para promover uma interação com naturalidade e que seja de qualidade. A qualidade, nesse caso, é determinada pela interação de longa duração, sem que o usuário queira se afastar do robô durante o processo. Alguns algoritmos de aprendizado que podem ser aplicados são: Aprendizado por Reforço, Rede Neurais, Árvores de Decisão, entre outros.

Nessa tese é apresentado um classificador Bayesiano do perfil do usuário, que utiliza informações sobre as ações do robô, percepção e comportamento do usuário, é construído para demonstrar os passos necessários que fazem parte do processo. Como o detalhe da construção deste classificador está totalmente ligado a aplicação do estudo de caso, ele é discutido no detalhe a partir da seção 5.12. 


\subsection{TESTES}

Assim como nos testes piloto, é importante adicionar um número considerável de perfis de usuários diversificados. É importante que exista uma boa distribuição para que ocorra a validação do mecanismo de tomada de decisão, na classificação ou na adaptação da interação de acordo com o perfil. Nesse momento, o especialista que observa o teste tem um papel importante e mais ativo, que no teste piloto. Durante a execução do experimento, o especialista deve fazer anotações que contribuam com o futuro do projeto. Esse é um processo similar ao teste com usuário realizado em projetos de interação humano-computador.

No processo são realizadas anotações sobre a interação, que o usuário não comunica através dos questionários. Por exemplo, recuar o corpo na direção contrária ao robô e expressões faciais de surpresa, medo e felicidade, durante a interação. Observações sobre o robô no cenário de teste também devem ser contempladas, principalmente quanto a melhorias de posicionamento de sensores, gestos e ações más interpretadas pelo usuário, e até defeitos na execução dos códigos. Outro ponto importante da etapa de testes é a entrevista realizada após o teste, onde o especialista realiza perguntas abertas para que o usuário fique a vontade em dizer mais sobre o produto e como ele se sentiu em determinadas ocorrências.

Essas informações são utilizadas para agregar mais conhecimento durante o processo de análise dos resultados, e são utilizados como insumo para melhorar a qualidade do projeto de interação humano-robô, em sua próxima iteração.

\subsection{ANÁLISES}

As informações coletadas através dos questionários e observações, são utilizadas para identificar problemas no projeto ou melhorias que devem ser feitas. Após identificar essas melhorias é importante que seja feita uma classificação de prioridades. Essa classificação deve ser numérica, trazendo a importância na sequência de execução. Classificações conceituais acabam dificultando na ordem de priorizar os pontos de melhoria de maneira efetiva. Para ajudar nessa classificação, testes estatísticos podem ser executados sobre as informações. Os testes que resultarem como irrelevantes, devem ser realizados de maneira não prioritária, pois exigem uma investigação mais aprofundada sobre o assunto e não deve ser feito na próxima interação. As informações que são estatisticamente significantes necessitam de uma atenção maior e devem ser priorizadas.

Testes estatísticos como ANOVA e teste T de Student devem ser utilizados a princípio, porém não devem ser descartados nenhum outro tipo de teste estatístico que se adéquem melhor ao tipo de dado obtido no resultado. Outro item que deve ser priorizado em nível 1 é o item de segurança. Qualquer ponto observado no teste que tenha problema de segurança ao usuário deverá ser realizado na próxima iteração. Com a lista de prioridades em mãos, basta iniciar a 
próxima interação. No capítulo 5 será aplicado o método apresentado ao longo deste capítulo, na construção de um classificador Bayesiano do perfil do usuário em formato de Personas. 


\section{ESTUDO DE CASO}

Com o método para construção de projetos de interação humano-robô centrado no usuário especificado no capítulo 4, um estudo de caso é apresentado. O escopo deste estudo de caso envolve a aproximação do robô para o ser humano em um ambiente doméstico simulado. $\mathrm{Na}$ etapa do mecanismo de tomada de decisão proposta no método é criado de um classificador Bayesiano para ilustrar essa etapa detalhadamente. As informações das ações do robô e informações de comportamento e percepção do usuário são consumidos para construção do classificador. A classificação do usuário é feita no formato de Personas, conforme proposto no método apresentado por essa tese no capítulo 4. A partir desse escopo é iniciado o desenvolvimento do classificador, a partir da definição das variáveis.

\subsection{VARIÁVEIS DE OBSERVAÇÃO}

Com base nas variáveis apresentadas na literatura, consolidadas na seção 4.1.2, foram mapeadas quais estão de acordo com o escopo. Elas devem possuir seus valores limitados para que simplifique as tabelas de probabilidades condicionais do classificador Bayesiano. A tabela 5 apresenta as variáveis e a restrição do domínio de cada uma.

Tabela 5 - Variáveis de observação escolhidas

\begin{tabular}{|c|c|}
\hline Variável & Valor \\
\hline Gestos & $\begin{array}{l}\text { curto } \\
\text { longo }\end{array}$ \\
\hline Estilo da Fala & $\begin{array}{l}\text { educada } \\
\text { autoritária }\end{array}$ \\
\hline Expressão Facial & $\begin{array}{c}\text { amigável } \\
\text { não amigável }\end{array}$ \\
\hline Proximidade & $\begin{array}{l}\text { longe - (Entre Pública e Social ) } \\
\text { perto - (Entre Pessoal e Íntima ) }\end{array}$ \\
\hline Velocidade & $\begin{array}{c}\text { rápida } \\
\text { devagar }\end{array}$ \\
\hline Posição & $\begin{array}{l}\text { sentado } \\
\text { em pé }\end{array}$ \\
\hline Conforto & $\begin{array}{l}\text { sim } \\
\text { não }\end{array}$ \\
\hline Medo & $\begin{array}{l}\operatorname{sim} \\
\text { não }\end{array}$ \\
\hline
\end{tabular}

Fonte: $\mathrm{O}$ autor.

As variáveis da tabela 5 são importantes, pois auxiliam a determinar o comportamento de reação do perfil do usuário para um mesmo tipo de ação do robô. Por exemplo, se o robô encontra-se próximo da pessoa, entre as zonas Pessoal e Íntima, um gesto com o manipulador com grande amplitude pode gerar um desconforto maior, do que o mesmo gesto ocorrendo entre 
as zonas Pública e Social. Outro cenário é a aproximação do manipulador próximo ao rosto do usuário, a reação é positiva ou negativa.

Alguns exemplos sobre os domínios das variáveis podem auxiliar a compreender quais são as ações correspondentes. Um exemplo para estilo de fala educada e autoritária são: "Por favor, poderia me auxiliar a encontrar minha garrafa" e "Encontre minha garrafa", respectivamente. Para ilustrar o domínio das expressões faciais é apresentada a figura 7.

Figura 7 - Exemplos das faces apresentadas pelo robô.

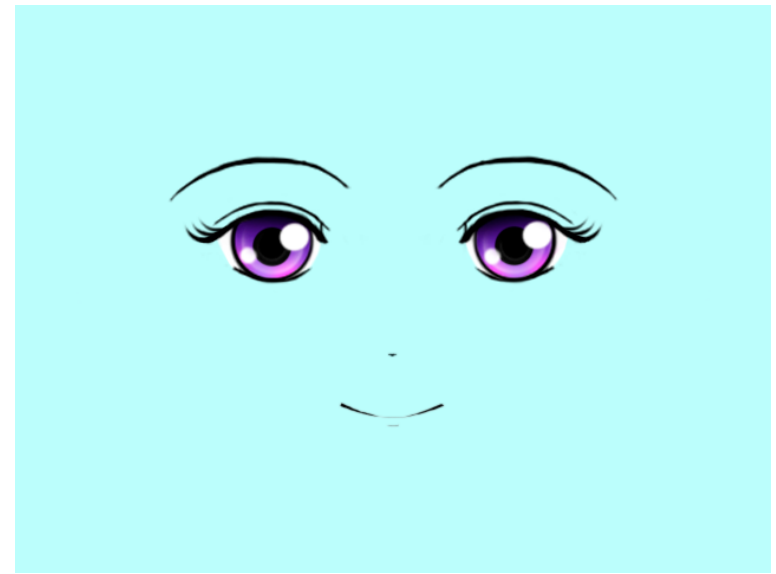

(a) Feliz

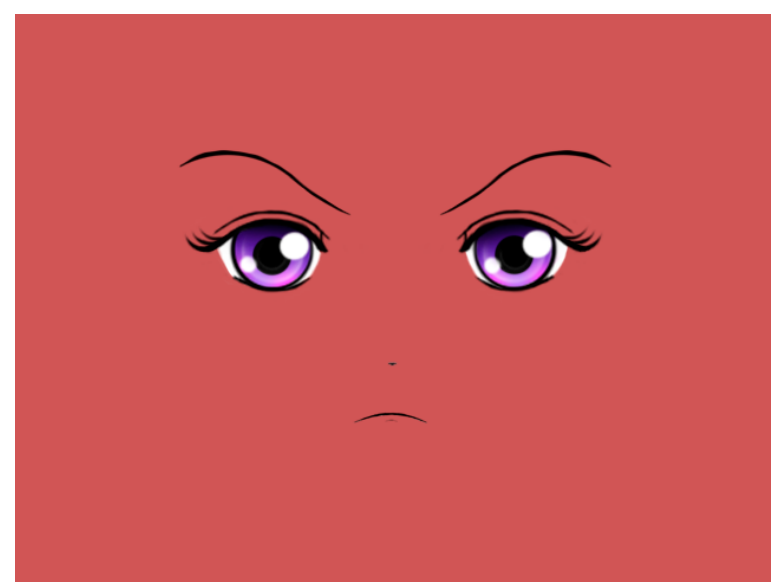

(c) Nervosa

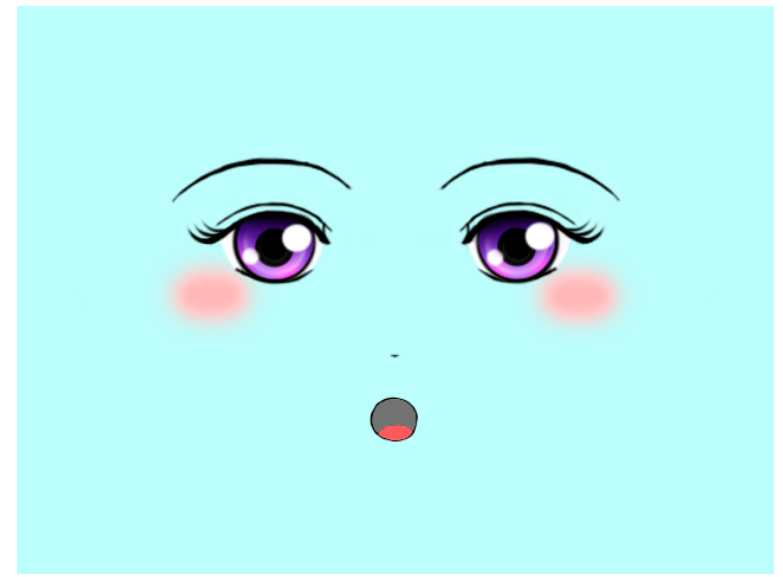

(b) Surpresa

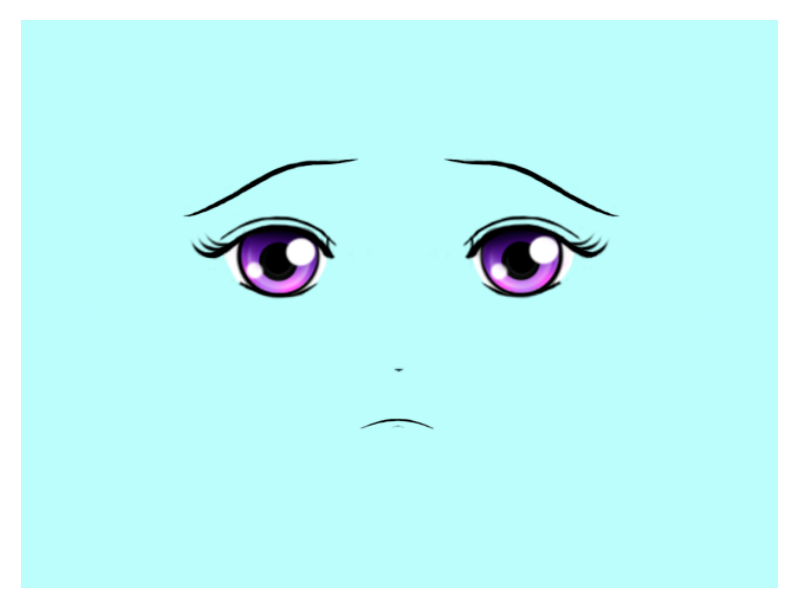

(d) Triste

Fonte: adaptado de (GONBATA; AQUINO JUNIOR, 2016).

Nos exemplos apresentados na figura 7, pode-se definir dentro do domínio da variável as figuras 7 a e $7 b$ como expressões amigáveis e as figuras 7c e 7d como não amigáveis, dado os sentimentos que essas expressões representam. As variáveis de conforto e medo são obtidas através da declaração do usuário através dos questionários pós teste, apresentado na seção 5.4. Com o domínio das variáveis definidos, o próximo passo é estabelecer o contexto de uso. 


\subsection{CONTEXTO DE USO}

A definição do contexto de uso é baseada em um texto descritivo que delimita todo o cenário da aplicação e como foi planejado o experimento. Esse cenário descreve quem é o usuário, quais os pontos de interação com o sistema, como será o comportamento do usuário e do robô. O contexto descrito delimita todo o escopo do teste. Ele assegura que as observações tenham o objetivo de garantir a qualidade do uso dentro daquele cenário. A figura 8 apresenta o cenário aplicado no contexto de uso dessa tese.

Figura 8 - Ilustração do contexto de uso

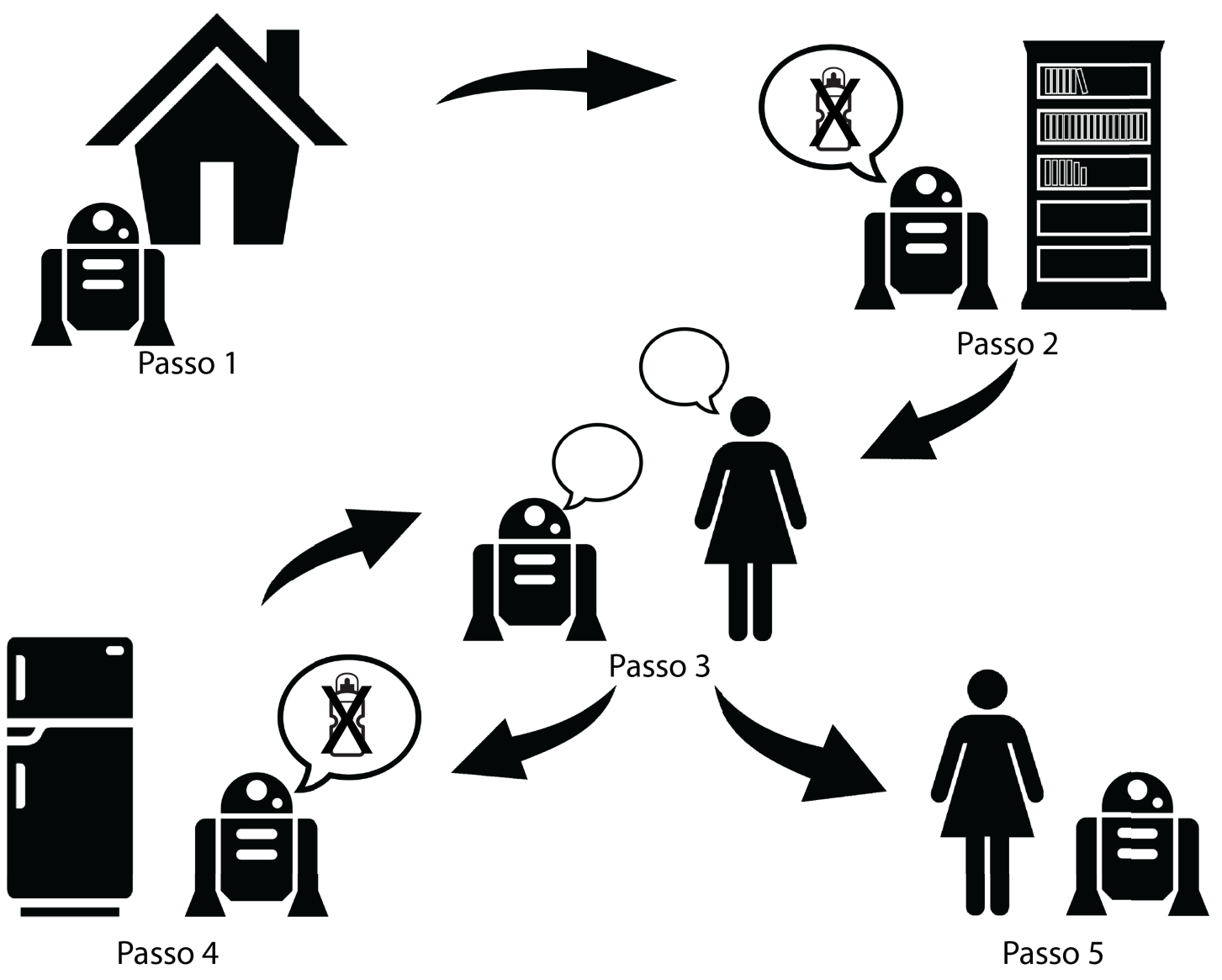

Fonte: o autor.

O cenário apresentado na figura 8 ilustra uma situação onde o robô entra em sua casa (passo 1) e vai até a estante onde ele deixou uma garrafa. A garrafa não está mais no local que ele deixou (passo 2), então ele vai até a pessoa que convive com ele no ambiente da casa. Ao interagir com a pessoa, o robô pergunta se ela viu a garrafa e recebe uma resposta negativa (passo 3). Na sequência, o robô procura pela garrafa em outro cômodo da casa, onde também não encontra (passo 4). O robô então retorna ao encontro da pessoa, e solicita a ajuda para procurar pela garrafa (passo 3). Como última etapa, a pessoa atende o pedido e ambos saem para procurar pela garrafa (passo 5), finalizando assim o cenário. 
Através dessa ilustração pode-se definir o contexto de uso desta tese, onde o robô realiza a aproximação de pessoas que convivem com ele dentro de uma casa. Essa aproximação é realizada com o objetivo de solicitar ajuda ao humano para encontrar um objeto que foi deixado em algum lugar da casa. Com as variáveis identificadas e o contexto de uso definidos, é necessário realizar a especificação dos questionários de pré e pós teste para saber o que será avaliado dentro do projeto.

\subsection{QUESTIONÁRIO PRÉ TESTE}

Para apoiar o processo de obtenção das informações e construção dos perfis dos usuários, são utilizados dois questionários. O primeiro, aplicado no momento anterior ao experimento de interação, tem como objetivo mapear as informações referentes às características físicas que tem a possibilidade do robô utilizar sensores para reconhecê-las, adesão a tecnologia, contatos prévios com robôs, questões culturais onde o usuário declara quais locais ele possui mais afinidade e quais ele já teve o privilégio de visitar, além da expectativa de possuir um robô em casa ou no trabalho. As questões são apresentadas na tabela 6 , onde a coluna construção contém os grupos de informações que conferem com a parte do perfil que elas auxiliam a preencher conforme apresentado por Barbosa e Silva (2010) e Baxter, Courage e Caine (2015). Todas as questões a seguir fazem parte do questionário pré-experimento.

Tabela 6 - Questões aplicadas no questionário pré teste

\begin{tabular}{l|l|l}
\hline Pergunta & Opções & Construção \\
\hline Informe seu nome completo & Texto Aberto & Identificação \\
\hline e-mail para contato & Texto Aberto & Contato Usuário \\
\hline Informe o número do seu celular & Texto Aberto & Contato Usuário \\
\hline $\begin{array}{l}\text { Testes poderão ocorrer usando o Robô no } \\
\text { Centro Universitário FEI. Você gostaria } \\
\text { de realizar o teste com o robô físico? }\end{array}$ & Sim; Não & Contato Usuário \\
\hline Qual a sua idade? (em anos) & Numérico & Demográfico \\
\hline Qual a sua altura? (em metros) & Numérico & Demográfico \\
\hline $\begin{array}{l}\text { Informa seu gênero } \\
\text { Na maior parte do tempo, você se consi- } \\
\text { dera uma pessoa com feição: }\end{array}$ & $\begin{array}{l}\text { Sorridente; Normino; Masculino; } \\
\text { Prefiro não dizer }\end{array}$ & Demográfico \\
\hline \begin{tabular}{l} 
Você se considera uma pessoa sociável? \\
\hline $\begin{array}{l}\text { Você utiliza óculos de grau? (Obs: Pes- } \\
\text { soas com lente de contato, por favor, res- } \\
\text { pondam não. A intenção é identificar a } \\
\text { armação.) }\end{array}$
\end{tabular} & Sim; Não & Social \\
\hline
\end{tabular}




\begin{tabular}{|c|c|c|}
\hline Você possui cabelo comprido? & Sim; Não & Físico \\
\hline Qual etnia você se considera? & $\begin{array}{l}\text { Amarela; Branca; Indí- } \\
\text { gena; Parda; Preta; Não } \\
\text { declarada }\end{array}$ & Etnográfico \\
\hline $\begin{array}{l}\text { Qual(is) dispositivo(s) tecnológico(s) } \\
\text { você mais utiliza (marque } 1 \text { ou mais } \\
\text { opções): }\end{array}$ & $\begin{array}{l}\text { Celular; Computador } \\
\text { (de mesa ou notebook); } \\
\text { Tablet; Smart TV; } \\
\text { Relógio Smart; MP3 } \\
\text { Player; Câmera Foto- } \\
\text { gráfica Digital; Leitor } \\
\text { de e-Book; outros }\end{array}$ & $\begin{array}{l}\text { Experiência com Tec- } \\
\text { nologias }\end{array}$ \\
\hline $\begin{array}{l}\text { Qual(is) dispositivo(s) tecnológico(s) } \\
\text { você nunca utilizou (marque } 1 \text { ou mais } \\
\text { opções): }\end{array}$ & 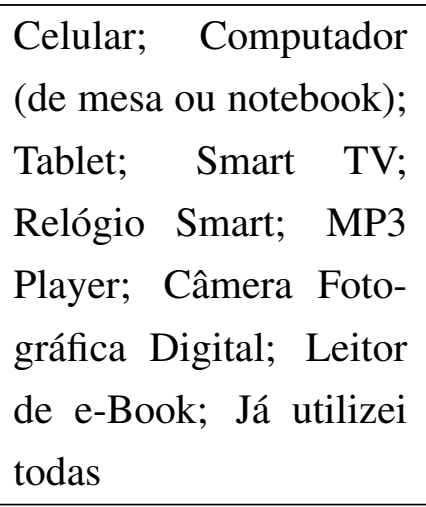 & $\begin{array}{l}\text { Experiência com Tec- } \\
\text { nologias }\end{array}$ \\
\hline $\begin{array}{l}\text { Você possui conta em banco digital (ex: } \\
\text { Original, Neon, etc.) ? }\end{array}$ & Sim; Não & Atitudes e Valores \\
\hline $\begin{array}{l}\text { Você possui cartão de crédito digital (ex: } \\
\text { Nubank, Digio, etc.) ? }\end{array}$ & Sim, Não & Atitudes e Valores \\
\hline $\begin{array}{l}\text { Qual o principal meio de pagamento de } \\
\text { suas contas? }\end{array}$ & $\begin{array}{l}\text { Celular; Computador; } \\
\text { Tablet; Autoatendi- } \\
\text { mento; Caixa Físico }\end{array}$ & Atitudes e Valores \\
\hline Você utiliza redes sociais? & Sim; Não & $\begin{array}{l}\text { Experiência com Tec- } \\
\text { nologias }\end{array}$ \\
\hline $\begin{array}{l}\text { Quais as redes sociais que você mais uti- } \\
\text { liza (marque } 1 \text { ou mais opções): (Se sim, } \\
\text { para a resposta anterior) }\end{array}$ & $\begin{array}{l}\text { Facebook, Instagram, } \\
\text { Twitter, Google Plus, } \\
\text { Snapchat, outras }\end{array}$ & $\begin{array}{l}\text { Experiência com Tec- } \\
\text { nologias }\end{array}$ \\
\hline $\begin{array}{l}\text { Qual foi o local de nascimento? (In- } \\
\text { forme da seguinte maneira: Cidade; Es- } \\
\text { tado; País) }\end{array}$ & Texto Aberto & Cultural \\
\hline $\begin{array}{l}\text { Em qual local, você viveu por mais tempo } \\
\text { durante sua infância e adolescência? (In- } \\
\text { forme da seguinte maneira: Cidade; Es- } \\
\text { tado; País) }\end{array}$ & Texto Aberto & Cultural \\
\hline
\end{tabular}




\begin{tabular}{|c|c|c|}
\hline $\begin{array}{l}\text { Qual o seu atual local de moradia? (In- } \\
\text { forme da seguinte maneira: Cidade; Es- } \\
\text { tado; País) }\end{array}$ & Texto Aberto & Cultural \\
\hline $\begin{array}{l}\text { Qual o país que você melhor se identifica } \\
\text { com a cultura? (Considere também a op- } \\
\text { ção do seu país de nascimento.) }\end{array}$ & Texto Aberto & Cultural \\
\hline $\begin{array}{l}\text { Qual a cidade, na sua opinião, que me- } \\
\text { lhor representa a cultura que você se iden- } \\
\text { tifica (resposta não dependente da questão } \\
\text { acima)? }\end{array}$ & Texto Aberto & Cultural \\
\hline $\begin{array}{l}\text { Você visitou outros países, além do Bra- } \\
\text { sil? }\end{array}$ & Sim; Não & Cultural \\
\hline $\begin{array}{l}\text { Quais países você já visitou? (Responda } \\
\text { separando os países por ponto e vírgula, } \\
\text { ex: França; Estados Unidos; Itália; Ja- } \\
\text { pão;) }\end{array}$ & Texto Aberto & Cultural \\
\hline $\begin{array}{l}\text { Aproximadamente, quantas cidades na re- } \\
\text { gião nordeste do Brasil você visitou? }\end{array}$ & Numérico & Cultural \\
\hline $\begin{array}{l}\text { Aproximadamente, quantas cidades na re- } \\
\text { gião norte do Brasil você visitou? }\end{array}$ & Numérico & Cultural \\
\hline $\begin{array}{l}\text { Aproximadamente, quantas cidades na re- } \\
\text { gião centro-oeste do Brasil você visitou? }\end{array}$ & Numérico & Cultural \\
\hline $\begin{array}{l}\text { Aproximadamente, quantas cidades na re- } \\
\text { gião sudeste do Brasil você visitou? }\end{array}$ & Numérico & Cultural \\
\hline $\begin{array}{l}\text { Aproximadamente, quantas cidades na re- } \\
\text { gião sul do Brasil você visitou? }\end{array}$ & Numérico & Cultural \\
\hline $\begin{array}{l}\text { Em algum momento de sua vida, você } \\
\text { teve contato com robôs? }\end{array}$ & Sim; Não & $\begin{array}{l}\text { Experiência com Pro- } \\
\text { duto }\end{array}$ \\
\hline $\begin{array}{l}\text { Se sim para a questão anterior, quais tipos } \\
\text { de robôs você teve contato (marque } 1 \text { ou } \\
\text { mais opções): }\end{array}$ & $\begin{array}{l}\text { Parecido com animais, } \\
\text { Parecido com pessoas, } \\
\text { Robôs de linha de pro- } \\
\text { dução/fábrica, Robôs } \\
\text { Móveis (que contém } \\
\text { rodas), outros }\end{array}$ & $\begin{array}{l}\text { Experiência com Pro- } \\
\text { duto }\end{array}$ \\
\hline $\begin{array}{l}\text { O que você espera do comportamento do } \\
\text { Robô ao tê-lo em sua casa? }\end{array}$ & Texto Aberto & $\begin{array}{l}\text { Experiência com Pro- } \\
\text { duto }\end{array}$ \\
\hline $\begin{array}{l}\text { O que você espera do comportamento do } \\
\text { Robô ao tê-lo em seu trabalho? }\end{array}$ & Texto Aberto & $\begin{array}{l}\text { Experiência com Pro- } \\
\text { duto }\end{array}$ \\
\hline
\end{tabular}




\begin{tabular}{l|l|l}
\hline $\begin{array}{l}\text { Dadas as questões anteriores, gostaria de } \\
\text { fazer mais algum comentário sobre você? }\end{array}$ & Texto Aberto & Comentários Aberto \\
\hline
\end{tabular}

Fonte: $\mathrm{O}$ autor.

A partir das informações coletadas com as questões apresentadas na tabela 6 , é possível determinar o perfil de cultura declarado pelo usuário, informações etnográficas que irão auxiliar na identificação da Persona. Expectativas sobre a interação com robôs em ambientes domésticos e profissionais, também são adquiridas. Essas informações auxiliam a determinar o ponto de partida para a análise e criação das personas discutidas no capítulo 4.

\subsection{QUESTIONÁRIO PÓS TESTE}

O questionário pós teste mantém o foco na interação do usuário que ocorreu durante o experimento e quais pontos do robô mais agradaram em sua opinião. Além disso, um detalhe sobre a posição do usuário durante o experimento (sentado ou em pé) é coletada, pois esta informação pode influenciar na interação com o robô. As questões apresentas na tabela 7, a seguir, compõe o questionário pós-teste.

Tabela 7 - Questões aplicadas no questionário pós teste

\begin{tabular}{l|l|l}
\hline Pergunta & Opções & Construção \\
\hline $\begin{array}{l}\text { Informe o número de amostra (Identifica- } \\
\text { dor dos documentos referentes ao comitê } \\
\text { de ética) }\end{array}$ & Numérico & Identificação \\
\hline $\begin{array}{l}\text { Você se sentiu confortável durante a apro- } \\
\text { ximação do robô? }\end{array}$ & $\begin{array}{l}\text { Escala Likert de 10 } \\
\text { pontos }\end{array}$ & Satisfação \\
\hline $\begin{array}{l}\text { Você se sentiu com medo em algum mo- } \\
\text { mento durante a aproximação do robô? }\end{array}$ & $\begin{array}{l}\text { Escala Likert de 10 } \\
\text { pontos }\end{array}$ & Satisfação \\
\hline $\begin{array}{l}\text { Você estava } \\
\text { mação do robô. }\end{array}$ & Sentado; em Pé & Uso \\
\hline $\begin{array}{l}\text { Você voltaria a interagir com esse robô } \\
\text { novamente? }\end{array}$ & Sim; Não & Satisfação \\
\hline Justifica a resposta anterior & Texto Aberto & Satisfação \\
\hline O que você mais gostou no robô? & Texto Aberto & Satisfação \\
\hline O que você menos gostou no robô? & Texto Aberto & Satisfação \\
\hline $\begin{array}{l}\text { Depois dessa experiência, você interagiria } \\
\text { com outros robôs? }\end{array}$ & Sim; Não & Satisfação \\
\hline $\begin{array}{l}\text { Você estaria confortável com um robô } \\
\text { convivendo em sua casa? }\end{array}$ & Sim; Não & Satisfação \\
\hline
\end{tabular}




\begin{tabular}{l|l|l}
\hline Justifique a resposta anterior. & Texto Aberto & Satisfação \\
\hline $\begin{array}{l}\text { Em algum momento da interação, você } \\
\text { se sentiu desconfortável com o compor- } \\
\text { tamento do robô? }\end{array}$ & Sim; Não & Uso \\
\hline $\begin{array}{l}\text { Descreva o desconforto em caso de sim, } \\
\text { na resposta anterior. }\end{array}$ & Texto Aberto & Uso \\
\hline $\begin{array}{l}\text { Você alteraria algum comportamento } \\
\text { apresentado pelo robô durante o teste? } \\
\text { Qual? }\end{array}$ & Texto Aberto & Uso \\
\hline Observações e comentários: & Texto Aberto & Comentários Aberto \\
\hline
\end{tabular}

Fonte: $\mathrm{O}$ autor.

Esse questionário tem o principal objetivo de coletar as informações que o usuário declarou não haver gostado na interação. As declarações ajudam a compreender o que deixou ele desconfortável e/ou com medo facilitando na hora de confortar com as observações do especialista realizadas durante a interação.

\subsection{PERFIS DE TESTE}

Foram selecionados, dentro da comunidade acadêmica, pessoas não portadoras de deficiência física ou motora. Os participantes são brevemente entrevistados sobre o conforto em permanecer com um robô de um metro e meio de altura, dentro de uma sala, junto com o especialista que acompanhará o teste e iniciará o robô no início do teste. Não havendo nenhum empecilho por parte do participante, após a leitura do termo de consentimento e esclarecido, os experimentos poderão ocorrer logo após a assinatura que estão de acordo em participar do teste. Os participantes são divididos de acordo com o apresentado na tabela 8.

Tabela 8 - Divisão das amostras entre os participantes

\begin{tabular}{l|l}
\hline Identificação do Grupo & Porcentagem de indivíduos \\
\hline Jovens & $70 \%$ \\
Idosos & $30 \%$ \\
\hline
\end{tabular}

Fonte: $\mathrm{O}$ autor.

\subsection{FUNCIONALIDADES}

Para criação das funcionalidades do robô utiliza-se as informações obtidas através do contexto de uso (vide seção 5.2) e das variáveis de observação (vide seção 5.1). Cada va- 
riável é analisada e verifica como elas auxiliam no contexto de uso. A partir desse ponto, é criado requisitos que contemplam as funcionalidades das variáveis. As variáveis de observação apresentadas na seção 5.1 foram quase todas utilizadas para a criação das funcionalidades apresentadas nessa tese. A única variável não utilizada foi o volume da voz emitida pelo robô, pois os testes foram executados em ambiente público. A variação do volume nessa condição tornouse inviável, pois ao diminuí-lo não era possível entender o que o robô dizia. Mais detalhes do ambiente de teste é apresentado na seção 5.8.

A tabela 9 apresenta a relação de funcionalidades consideradas nessa tese e qual variável foi responsável pela funcionalidade.

Tabela 9 - Funcionalidades do projeto de IHR.

\begin{tabular}{c|c|l}
\hline Variável & ID & Funcionalidade \\
\hline \multirow{2}{*}{ Aproximação } & F01 & Reconhecer o ambiente \\
\cline { 2 - 3 } & F02 & Controlar velocidade de navegação \\
\cline { 2 - 3 } & F03 & Controlar proximidade da pessoa \\
\hline \multirow{2}{*}{ Manipulador } & F04 & Controlar gestos \\
\cline { 2 - 3 } & F05 & Controlar força do manipulador \\
\hline \multirow{2}{*}{ Estilo de Voz } & F06 & Falar com diferentes níveis de "educação" \\
\cline { 2 - 3 } & F07 & Identificar a fala da pessoa \\
\hline \multirow{2}{*}{ Expressão Facial } & F08 & Possuir diferentes estilos de face \\
\cline { 2 - 3 } & F09 & Apresentar o estilo de face de acordo com a interação \\
\hline \multirow{2}{*}{ Fonte: O autor. } & \multicolumn{2}{|c}{}
\end{tabular}

Cada uma das nove funcionalidades apresentadas na tabela 9 estão ligadas diretamente as interações previstas no contexto de uso. Para cada uma é necessário pelo menos um sensor para perceber os eventos externos ao robô e/ou um atuador para externar a funcionalidade ao objeto de interação. Os sensores e atuadores necessários são discutidos na seção 4.1.7, a seguir.

\subsection{SENSORES E ATUADORES}

Com a lista de funcionalidades definidas, agora é necessário determinar quais são os sensores e atuadores do robô que são capazes de atender cada uma das necessidades do projeto. Para a primeira funcionalidade F01 - Reconhecer o ambiente, o robô precisa de dois tipos de sensores, lasers e câmeras de vídeo. Esses sensores são capazes de determinar a distância entre um obstáculo e o robô, e também determinar o que ele enxerga no ambiente. Os atuadores envolvidos são os motores e servo-motores responsáveis pela locomoção do robô e movimento do manipulador.

Na funcionalidade F02 - Controlar Velocidade de Navegação, o robô necessita identificar quais são os obstáculos mais próximos para determinar qual velocidade ele por exercer na navegação. Para isso, é utilizado sensores lasers e atuação nos motores de movimentação do robô. A F02 está ligada a funcionalidade F03 - Controlar Proximidade da Pessoa. Na F03 
o robô precisa de um sensor laser de movimento, como o Microsoft $\AA$ Kinect $\AA$ ou ASUS $\mathbb{R}$

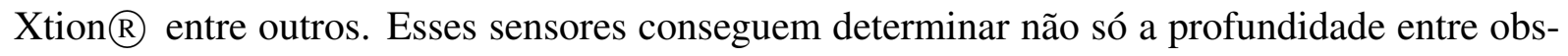
táculos e o robô, mas também conseguem determinar o local da pessoa e quais partes do corpo dela estão mais próximas do robô. Dessa forma, é possível determinar a velocidade do motor para que o robô não atropele ou se aproxime de maneira ofensiva da pessoa.

As funcionalidades F04 - Controlar Gestos e F05 - Controlar Força do Manipulador, ligadas a variáveis manipulador, estão ligadas diretamente a atuação dos servo-motores presentes no manipulador. Para a F04 ainda é necessário o uso do Kinect $\AA$ para verificar se não haverá colisão com a trajetória do manipulador. Já a força do manipulador correspondente a F05, é feito a leitura da corrente elétrica no servo-motor e caso haja um pico nela, o manipulador para o movimento e quando possível recua a posição inicial. Para a F06 - Falar com diferentes níveis de "educação", basta controlar via software qual frase o robô emitirá através de seus alto-falantes. E na F07 - Identificar a fala da pessoa, é necessário um microfone direcional para auxiliar a eliminar o ruído do ambiente e capturar a voz da pessoa com que o robô interagirá.

Referente a expressão facial do robô, as funcionalidades F08 - Possuir diferentes estilos de face e F09 - Apresentar o estilo de face de acordo com a interação, o robô necessita de uma tela que seja capaz de exibir suas expressões ao longo da sua interação. É importante atender essas funcionalidades dado o contexto da interação humano-robô ser social e entre agentes que convivem no mesmo ambiente. No caso desta tese, optou-se por um tablet que fosse capaz de comportar um navegador web que fosse capaz de interagir com o software adotado no desenvolvimento do sistema.

A tabela 10 apresenta a síntese dos sensores e atuadores listados para atender as funcionalidades do projeto e portanto devem estar contidos no robô utilizado para interagir com o ser humano.

Tabela 10 - Sensores e atuadores do projeto de IHR.

\begin{tabular}{l|l}
\hline Categoria & Descrição \\
\hline \multirow{4}{*}{ Sensores } & Light Detection And Ranging (LIDAR) / laser \\
\cline { 2 - 2 } & Sensor de movimento Microsoft@ Kinect@ \\
\cline { 2 - 2 } & Câmera de vídeo \\
\cline { 2 - 2 } & Microfone direcional do tipo shotgun (longo alcance) \\
\hline \multirow{4}{*}{ Atuadores } & Tablet \\
\cline { 2 - 2 } & Manipulador (Servo-motores) \\
\cline { 2 - 2 } & Motores para locomoção \\
\cline { 2 - 2 } & Alto-falantes \\
\hline
\end{tabular}

Fonte: $\mathrm{O}$ autor.

Os detalhes de implementação de cada sensor e atuador listado na tabela 10, é apresentado na seção 5.9 onde é discutido a preparação do robô para execução dos testes realizados. 


\subsection{CENÁRIO DE TESTE}

O teste é realizado em um ambiente que simula uma residência, conforme apresentado na figura 9. No ambiente, o robô navega de maneira autônoma, sem nenhuma intervenção de telecomando, a procura de uma garrafa que deixou no armário. Como ele não encontra a garrafa, o robô sai a procura de uma pessoa que esteja na casa para ajuda-lo. Ele interage com a pessoa, e pode solicitar que a pessoa o siga para algum lugar do cenário, à procura de sua garrafa. Essas tarefas estão de acordo com as necessidades do projeto e também do seu contexto de uso, conforme apresentado nas seções anteriores deste capítulo.

Figura 9 - Cenário para teste de interação com o robô.

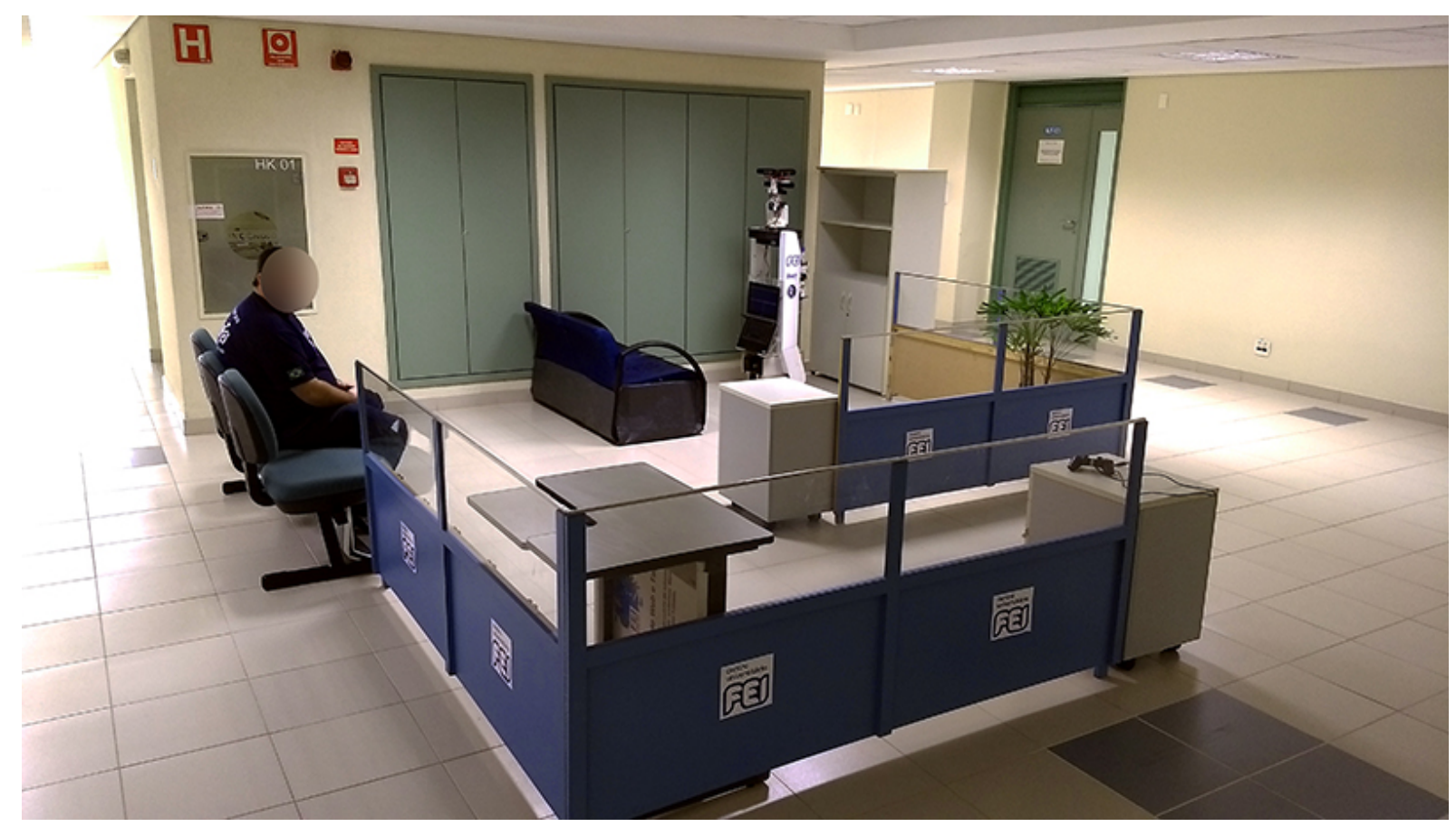

Fonte: Autor.

\subsubsection{Objetivo}

Verificar a compreensão e conforto da pessoa ao observar e interagir com o robô no ambiente doméstico, afim identificar experiências positivas e negativas por parte do usuário.

\subsubsection{Estados de Comportamento do Humano}

Para o teste são consideradas algumas possibilidades de posicionamento da pessoa e robô para interagirem:

a) Pessoa parada em pé e o robô inicia a interação próximo do usuário.

b) Pessoa parada em pé e o robô inicia a interação distante do usuário. 
c) Pessoa parada sentada e o robô inicia a interação próximo do usuário.

d) Pessoa parada sentada e o robô inicia a interação distante do usuário.

O objetivo das configurações é a aleatoriedade do posicionamento entre robô e pessoa, considerando cenários doméstico onde o convívio é comum. Assim, é possível medir a experiência do usuário em diversas situações de convivência.

\subsubsection{Tarefa do Robô}

Esse teste ocorre em um ambiente controlado, porém o trânsito de outros indivíduos pelo cenário acontece com frequência significativa. O passo a passo da tarefa é descrito na lista a seguir:

a) Início: O robô é posicionado no cenário de maneira que esteja em um local em torno da residência simulada.

b) Busca pelo objeto: O robô segue até uma mesa, ou armário, onde supostamente deixou sua garrafa.

c) Interação com a pessoa: $O$ robô se aproxima do usuário e questiona se ele viu a garrafa.

d) Nova busca pelo objeto: O robô segue a um novo ponto em busca da garrafa, que novamente não está no local.

e) Retorno ao usuário: O robô retorna ao local onde o usuário se encontra e, em uma distância maior ou menor de proximidade (aleatória), solicita que o usuário o acompanhe.

f) Fim: Será considerado o fim da tarefa, quando o robô alcançar um ponto ao redor do cenário e informar o fim do teste ao participante.

As tarefas são definidas com base no contexto de uso ilustrado através da figura 8 . Nesse ponto, o projeto está especificado, os equipamentos e ambiente prontos para realizar a interação humano-robô. Como é um experimento que envolve testes com ser humano, é importante enviar o projeto para apreciação do comitê de ética através da ferramenta Plataforma Brasil. Esse projeto tem a aprovação do comitê de ética, através do número de processo CAAE: 70057117.0.0000.5508, que pode ser lido na íntegra no apêndice 7.

\subsection{PREPARAÇÃO DO ROBÔ}

O robô utilizado no desenvolvimento da tese é o PeopleBot ${ }^{1}$ fabricado pela ActivMedia Robotics. Ele é um robô móvel com direção diferencial, ou seja, possui duas rodas motorizadas e uma roda castor que auxilia em seu equilíbrio. O projeto do PeopleBot tem foco em pesquisas e serviços que envolvem interação humano-robô. Com esse objetivo, ele foi desenvolvido

\footnotetext{
${ }^{1}$ PeopleBot - http://www.mobilerobots.com/researchRobots/PeopleBot.aspx
} 
com uma altura de $112 \mathrm{~cm}$ (centímetros). Além disso, o PeopleBot também possui uma garra pequena que tem sua movimentação apenas na direção vertical. A figura 10 apresenta o robô PeopleBot.

Figura 10 - Robô ActivMedia Robotics PeopleBot.

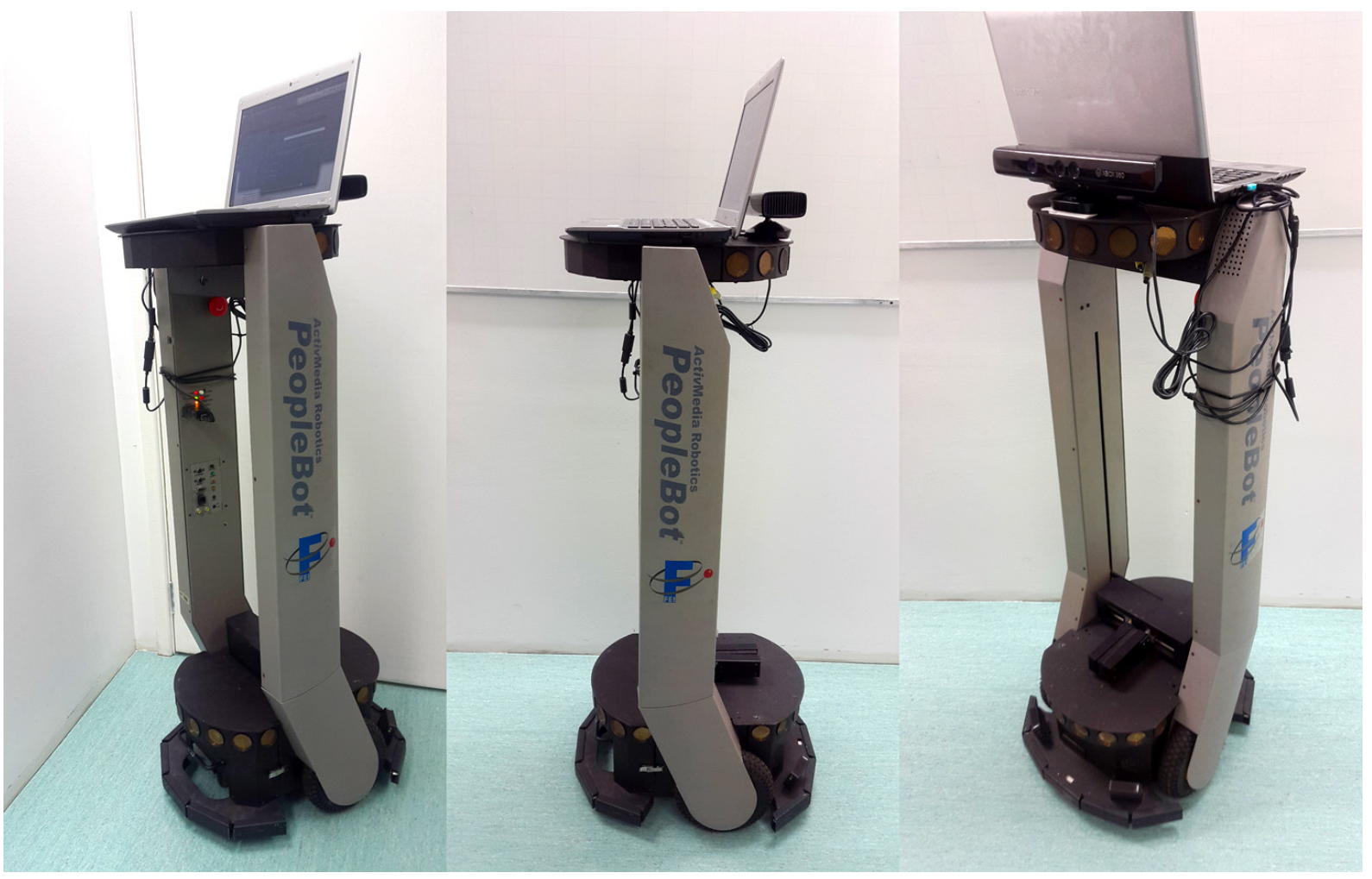

Fonte: Autor.

Como a garra do PeopleBot é curta e não permite muita destreza na manipulação de objetos e gestos, além de possuir poucos graus de liberdade, foi construído e adicionado um novo manipulador. O projeto do manipulador foi desenvolvido com o intuito de auxiliar a manipulação de objetos a uma certa distância e execução de gestos durante interações com pessoas. Esse novo manipulador é importante já que durante a interação social, seres humanos gesticulam para ilustrar a intenção e fala do que querem transmitir, por exemplo, acenar com as mãos ao falar olá. Esse tipo de comportamento aproxima naturalidade a interação humano-robô, podendo gerar um conforto a pessoa que interage. O projeto atende pesquisas com foco em prestação de serviços domésticos e cuidados pessoais, e foi construído de maneira que os movimentos sejam próximos do braço humano. O desenho que ilustra o manipulador desenvolvido é apresentado através da figura 11.

Além do manipulador, também foi acoplado um tablet para que seja possível atribuir face ao robô e consequentemente expressões faciais, deixando a interação mais amigável. $\mathrm{O}$ projeto da cabeça do robô é apresentado na figura 12.

O projeto da cabeça foi preparado para acoplar alguns sensores como o Microsoft $\mathbb{R}$ Kinect $\cap$, o ASUS $\cap$ Xtion $($ e webcams, para tarefas que envolvam nuvem de pontos de pro- 
Figura 11 - Projeto do Novo Manipulador do PeopleBot.

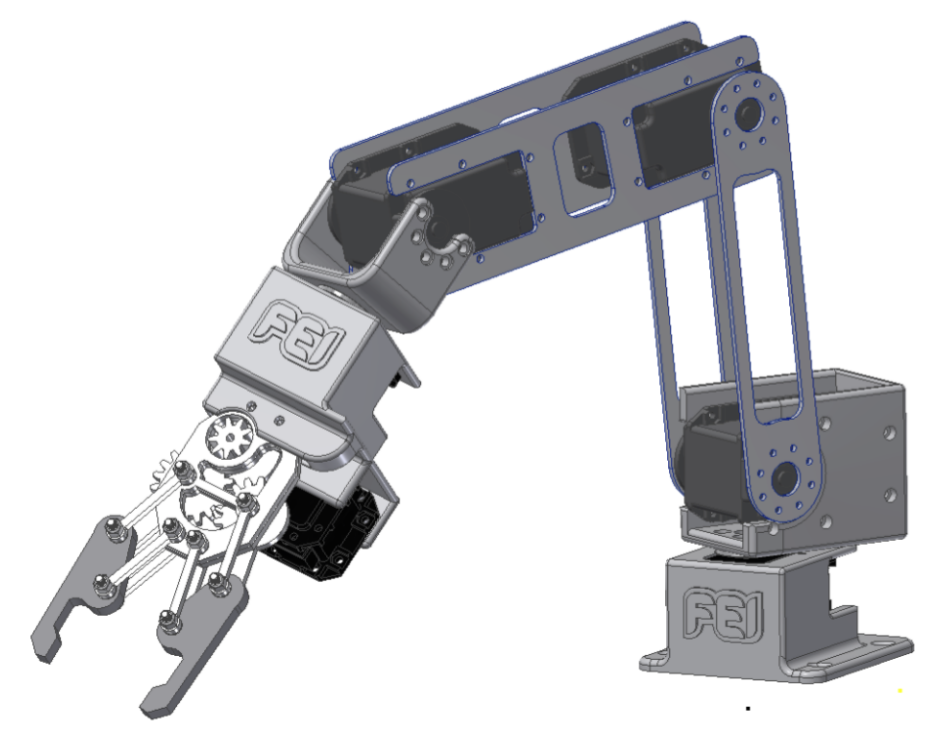

Fonte: Gonbata e Aquino Junior (2016).

Figura 12 - Projeto da Cabeça para o

PeopleBot.

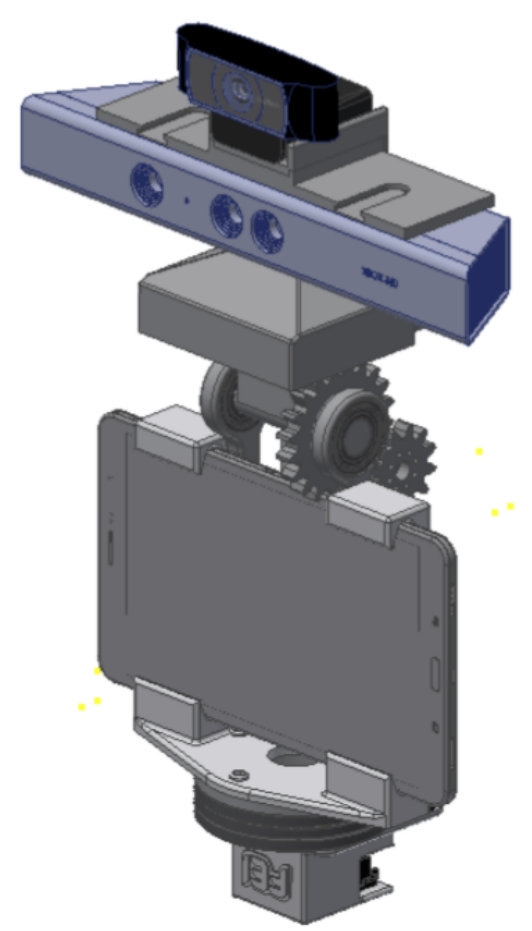

Fonte: Gonbata e Aquino Junior (2016).

fundidade e visão computacional. Sensores como lasers e microfones também foram instalados para melhorar a captura de informações sobre o ambiente e interagir melhor com a pessoa. $\mathrm{O}$ sensor laser utilizado foi o Hokuyo URG-04LX-UG01 que possui um alcance de 5 metros, suficiente para navegação em um ambiente doméstico. O microfone, por se tratar de um ambi- 
ente com ruído e que a interação possuí diferentes distâncias para ocorrer, optou-se por um tipo shotgun que tem o alcance de aproximadamente 2 metros. O modelo do microfone é o RODE Videomic Pro. O desenvolvimento do manipulador e da cabeça do robô foram realizados no projeto apresentado por Gonbata e Aquino Junior (2016) que ocorreu em paralelo, durante a preparação do robô.

Durante os primeiros testes, a base do Peoplebot sofreu uma avaria e foi substituída por uma base da KUKA. É uma base com rodas omnidirecionais que proporcionam uma maior mobilidade de direções para o robô. A figura 13 apresenta a montagem final do robô para realização dos testes de interação na residência.

Figura 13 - Robô Judith na sua montagem final.

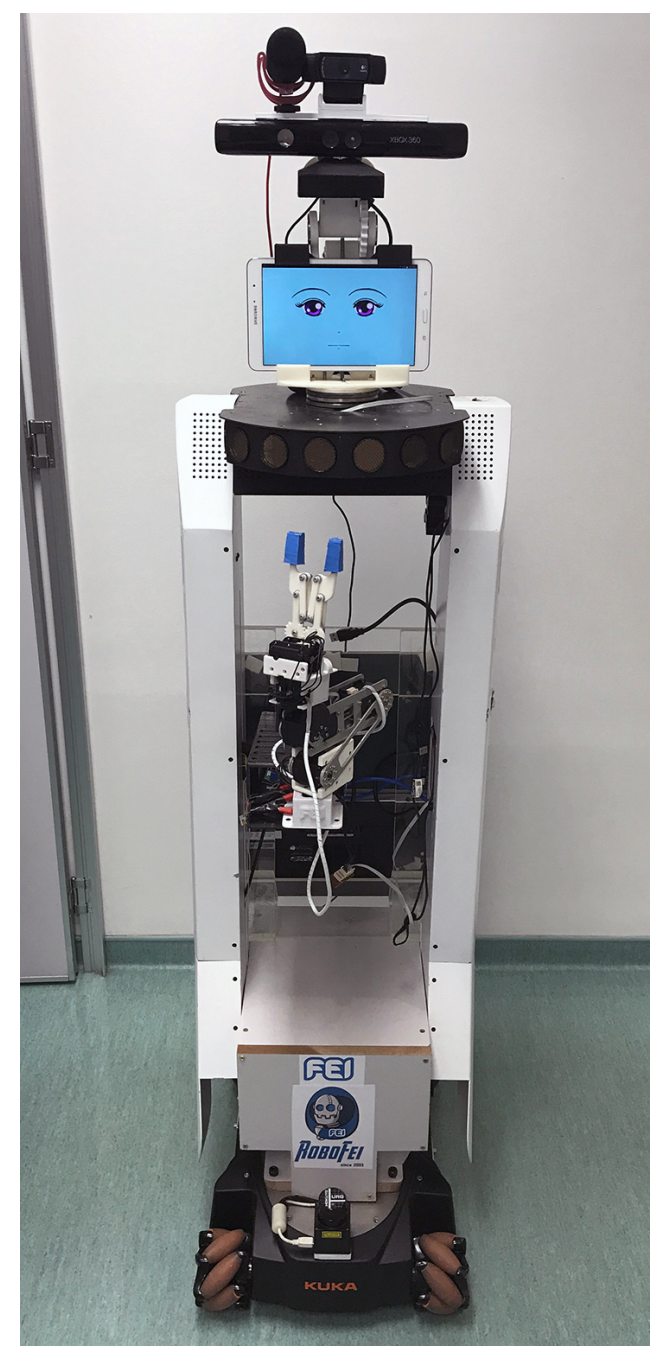

Fonte: Autor.

Além dos preparativos mecânicos para possibilitar a execução, de cada comportamento que atende as funcionalidades do projeto, também é necessário preparar os softwares que irão compor a inteligência do robô. A arquitetura do robô e bibliotecas utilizadas para a composição do software são apresentadas nas seções a seguir. 


\subsubsection{Arquitetura do Software}

A arquitetura construída para o software do robô foi feita em camadas. Ela segue as diretrizes de arquitetura do ROS. O nó master, criado ao inicializar o ROS, cria um servidor DNS. A partir desse servidor, novos nós são conectados através de um protocolo TCP/IP utilizando biblioteca de socket. Após conectado, um nó, pode enviar uma mensagem de comunicação via protocolo de rede. Essa mensagem é distribuída através do processo de broadcast. Isso significa que o nó fica emitindo informações na rede, sem um alvo específico e qualquer indivíduo dentro da rede pode interceptar essas informações. As mensagens são publicadas através de tópicos. A partir desse ponto, qualquer nó que queira ler a mensagem pode se inscrever no tópico. A ilustração dessa operação é apresentada através de figura 14.

Figura 14 - Ilustração do funcionamento do ROS.

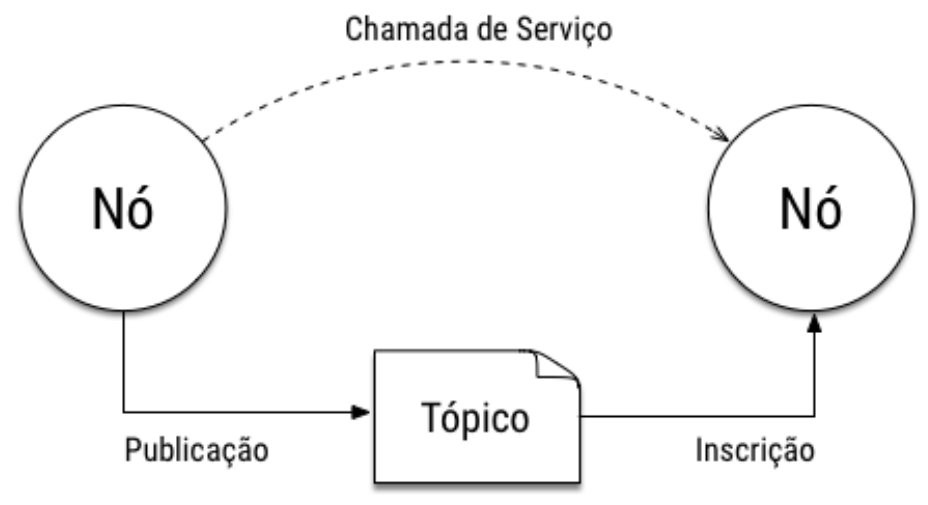

Fonte: Autor.

Dessa forma é fácil separar os códigos responsáveis em pacotes e camadas que mantenham um funcionamento independente. Então quando for necessário adicionar um novo código ou funcionalidade, basta criar um novo pacote ou um novo nó que irá atendê-la. Assim, o pacote approach_control foi desenvolvido. A figura 15 apresenta as camadas do pacote approach_control construído com base nos princípios do ROS.

As camadas forma divididas em 9 principais grupos. Cada grupo tem um objetivo específico. A primeira é a interface do robô, que através das máquinas de estado, controlam a comunicação entre todos os nós do sistema e o robô. A camada de controle concentra todos os pacotes que fazem os algoritmos de controle e determinam os parâmetros dos atuadores do robô. A camada de reconhecimento possui todos os algoritmos de reconhecimento utilizados no robô. Nela estão os pacotes para reconhecimento de face e gênero, que utilizam o framework OpenCV, do esqueleto do usuário, através da biblioteca do PyOpenNI e o de fala que redireciona o que foi recebido para o DragonFly, que implicitamente utiliza o Windows Speech para reconhecer a fala. Saída sonora é uma camada que trata apenas o evento para uma chamada ao programa de reprodução de áudio SoundPlay, que é nativo ao sistema operacional Linux. Ele 
Figura 15 - Arquitetura do projeto para o classificador Bayesiano.

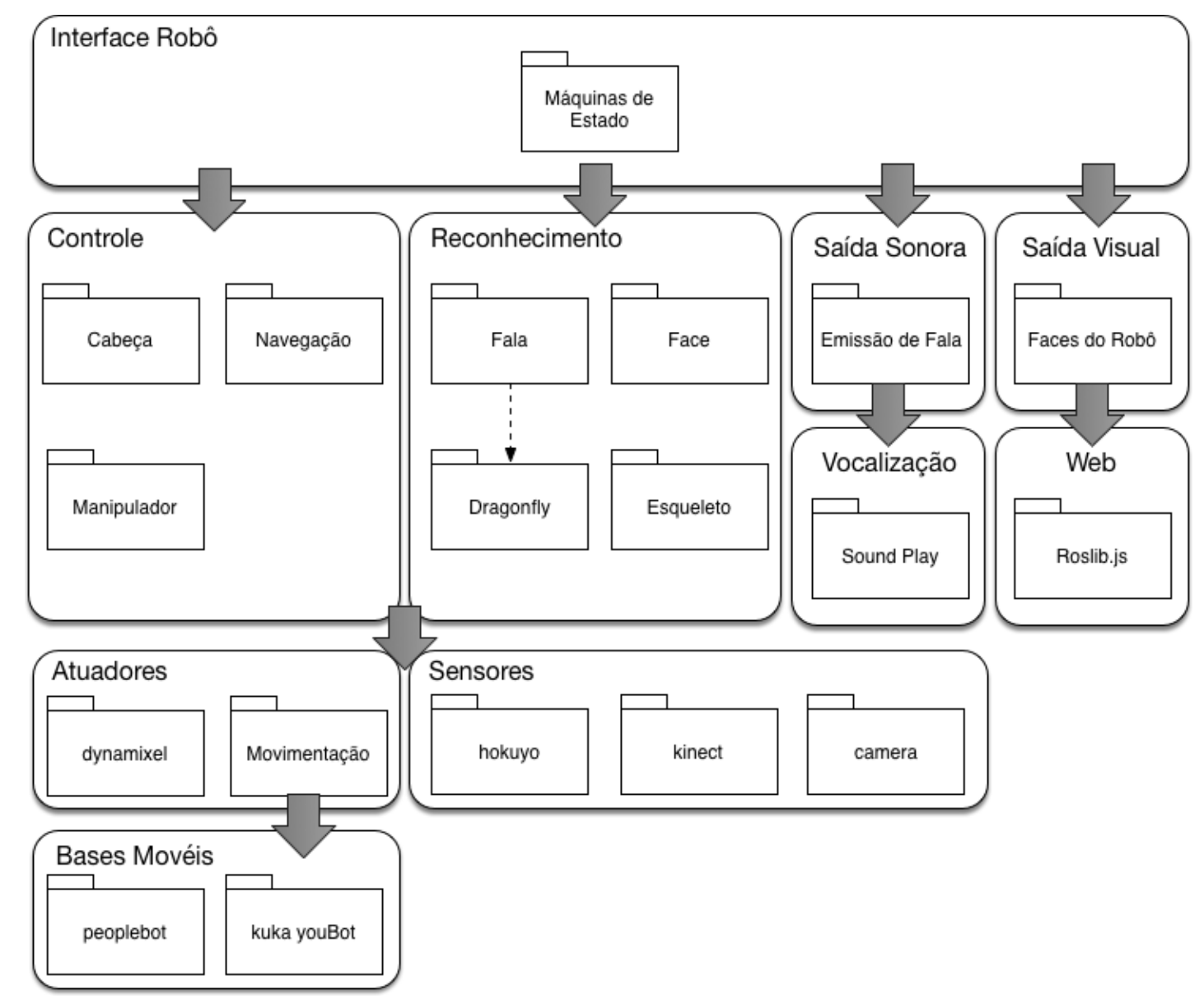

Fonte: Autor.

ficou em uma camada separada, pois pode inserir qualquer outro programa de reprodução de voz. Em uma camada separada, facilita a expansão e mudança de softwares utilizados e também o uso de outros pacotes.

A camada de saída visual tem uma página HTML que utiliza uma outra camada web para deixar a face do robô dinâmica. Ela trabalha com as mensagens enviadas na rede do ROS e recebe essas informações através do componente roslib.js que é um wrapper para a camada interna TCP/IP criada através do nó master. Também foi criado uma camada de atuadores e sensores que mantém a última versão funcional dos pacotes que possuem os drivers de comunicação de cada uma das bases robóticas utilizadas no projeto do estudo de caso do método centrado no usuário de interação humano-robô. A relação entre os pacotes criados e existentes no repositório approach_control ${ }^{2}$ pode ser observado através da figura 16.

Essa estrutura permite a expansão e também a troca de algoritmos, softwares e componentes de maneira mais fácil e sem muito esforço ou retrabalho ao codificar as novas soluções, além da refatoração do código fonte do robô ser mínima.

\footnotetext{
${ }^{2}$ https://github.com/amasiero/approach_control
} 
Figura 16 - Arquitetura de componentes que representam os softwares construídos no pacote approach_control.

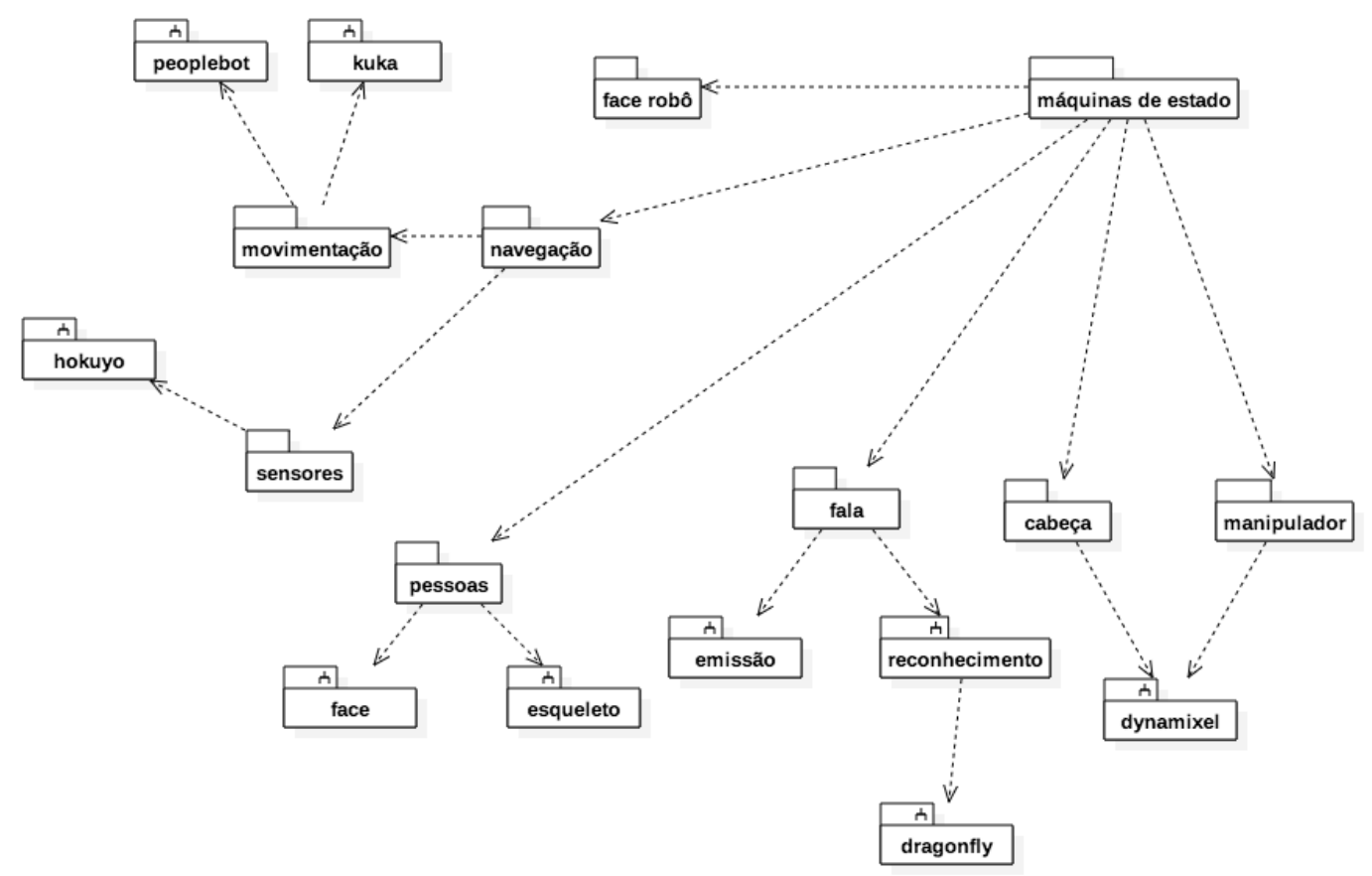

Fonte: Autor.

\subsubsection{Bibliotecas}

Para auxiliar no desenvolvimento da tese, algumas bibliotecas e softwares foram utilizados. O primeiro, conforme dito na seção 5.9.1, foi o ROS que é um framework para desenvolvimento de software em robôs. Ele roda sobre o Ubuntu Linux, que no caso da tese foi utilizado a versão 14.04, com o ROS versão Indigo.

A biblioteca que gerencia a máquina de estados criada para execução das tarefas é o $\mathrm{SMACH}^{3}$. Ele possibilita a criação e realiza o gerenciamento dos estados durante a execução das ações do robô. Para reconhecimento de voz a biblioteca utilizada foi o Dragonfly Speech Recognition ${ }^{4}$. Bibliotecas como o OpenCV ${ }^{5}$, PyOpenni ${ }^{6}$ e MoveIt! ${ }^{7}$ foram utilizados para percepção e interação com o ambiente e também com o usuário. O programa que realiza a interação da face do robô foi desenvolvido em HTML e Javascript. Ele encontra-se disponível através do endereço https://github.com/amasiero/robot_face.

Todos os pacotes desenvolvidos utilizaram a linguagem de programação Python, que possibilitou diversas facilidades na implementação dos códigos e integração das camadas dos pacotes no ROS. Para criação e teste da rede Bayesiana proposta utilizou-se o framework Sa-

\footnotetext{
${ }^{3}$ http://wiki.ros.org/smach

${ }^{4}$ https://pypi.python.org/pypi/dragonfly/0.6.5

${ }^{5} \mathrm{http}: / /$ opencv.org/

${ }^{6}$ https://github.com/jmendeth/PyOpenNI

${ }^{7}$ http://moveit.ros.org/
} 
mIam ${ }^{8}$, que realiza os cálculos de todas as probabilidades de uma consulta a rede de maneira objetiva.

\subsection{TESTES PILOTO}

Antes de realizar o teste piloto é importante que o projeto submetido ao comitê de ética esteja aprovado, vide apêndice 7. Nesse ponto o usuário é convidado a interagir com o robô. $\mathrm{O}$ especialista posiciona o usuário no ambiente de teste, onde ele pode ficar sentado ou em pé. Câmeras são posicionada de maneira que o possam capturar as reações que o usuário terá durante toda a interação com o robô. O especialista explica todos os procedimentos do experimento e da o sinal para que o robô inicie o teste. O sinal ocorre através de um comando de voz para o robô. Durante todo o experimento o usuário é incentivado a falar em voz alta o que está passando pela sua cabeça. Com as informações faladas e observações visuais, que são feitas pelo próprio especialista, são gerados pontos de atenção para melhoria e até pontos de sucesso no projeto. Ao final, o usuário é encaminhado para preencher o questionário pós teste, apresentado em detalhes na seção 5.4.

É importante delimitar os usuários que farão os testes de maneira criteriosa. Os perfis dos selecionados podem levar a diferentes resultados na interação. Os usuários selecionados para realizar o teste, são denominados de sujeito de teste. Nessa tese o seguinte perfil foi utilizado: pessoas que possuem idades diversificadas com variedade de 18 a 70 anos. Alguns candidatos ao teste possuem medo declarado de robôs e neste caso o especialista ficará acompanhando o teste com uma maior proximidade para evitar problemas com o robô e principalmente com a pessoa.

São evitados a repetição de configuração entre os candidatos, para que não seja levantado nenhum conhecimento a priori sobre o comportamento do robô.

\subsubsection{Heurísticas de Interação Humano-Robô}

Durante os testes piloto, percebeu-se que algumas heurísticas de avaliação de interação foram percebidas pelo usuário. Dessa maneira, foi realizado um trabalho para inclusão das variáveis na lista de variáveis de observação.

Avaliação heurística é um método utilizado por especialistas em usabilidade para verificar problemas de interação em interfaces de sistemas e produtos. Nielsen (1994) apresenta 10 heurísticas para avaliações de interfaces em sistemas web (vide seção 3.2). As heurísticas de Nielsen têm sido amplamente utilizadas ao longo dos tempos para sites e sistemas desktop. Alguns trabalhos discutidos ao longo da seção 3.3 apresentam modificações das heurísticas de Nielsen para o cenário de interação humano-robô.

\footnotetext{
${ }^{8}$ http://reasoning.cs.ucla.edu/samiam/
} 
Nos questionários pré e pós teste preenchido pelos usuários, notou-se que apontavam no robô a falta ou a presença de características que representavam as heurísticas de avaliação. Cada usuário dava mais atenção a determinadas características, que compunham diferentes perfis de interação. Assim, as heurísticas de avaliação apresentadas pela literatura foram estudadas. A partir desse estudo, verificou-se que as heurísticas mais presentes nos comentários dos usuários, também estavam presentes nas listas contidas na literatura. Dentre as heurísticas que apresentam uma descrição de maior aplicabilidade em robótica social e interação humano-robô estão as heurísticas de Clarkson e Ronald C Arkin (2007) (vide tabela 3).

Nesse momento é realizado a seleção das heurísticas em comum com os comentários dos usuários. Essas heurísticas são transformadas em variáveis que compõem a rede bayesiana, a fim de auxiliar na classificação do perfil do usuário em interação. Com base nas observações e comentários dos testes de interação, mais os estudos da literatura, foi possível identificar as seguintes heurísticas para transformá-las em variáveis que formam o conjunto de classificação do usuário:
a) Visibilidade do estado do sistema;
b) Uso de sugestões naturais;
c) Síntese do sistema e interface;
d) Ajudar o usuário a reconhecer, diagnosticar, e recuperar de erros.

Cada uma das heurísticas apresentadas na lista acima, foram observadas durante os testes através dos comentários dos participantes. Assim, elas apresentam dependência condicional com os perfis e/ou com as ações do robô. Por exemplo, sobre a questão da visibilidade do estado do sistema (robô), alguns participantes comentaram que o robô poderia sempre informar os próximos passos. Esse comportamento faria com que o participante ficasse mais confortável com o robô pela casa. Sobre a questão da naturalidade dos movimentos e fala, participantes não conseguiram entender os gestos do manipulador, até o que robô falasse algo que complementa os gestos. Isso ocorreu também devido às limitações físicas do manipulador desenvolvido (vide figura 11). Após avaliar as heurísticas de Clarkson e Ronald C Arkin (2007) com os comentários dos usuários, definiu-se o conjunto de heurísticas apresentado acima.

\subsection{CRIAÇÃO DAS PERSONAS}

A execução do QG-SIM foi realizada com três valores $\mathrm{Q}$ diferentes, $0.6,0.7$ e 0.8 . Após cada execução é verificado como foi realizado o agrupamento, para que não existam grupos muito generalizados e nem grupos muito especializados. Para o valor $Q=0.6$, foram encontrados 3 grupos, dois grupos com 1 pessoa cada e um grupo contendo os demais perfis. Ficou muito generalizado. O próximo valor testado foi de $Q=0.8$. Nesse caso, o resultado foi muito específico, pois houve 9 grupos sendo grande parte com 1 ou 2 perfis e poucos grupos com 5 perfis. O valor intermediário $Q=0.7$, apresentou um comportamento melhor onde encontrou 5 grupos. 2 grupos com 1 perfil cada, 1 grupo com 7, outro com 9 e o maior com 21. 
Alguns fatores, como idade, redes sociais, contato com robôs, entre outros foram determinantes para esse resultado. Detalhes sobre cada grupo é apresentado no capítulo 6. Agora que os grupos estão definidos, deve-se criar as Personas que representam cada um deles.

Cinco Personas foram construídas. Essas são apresentadas nas tabelas 11, 12, 13, 14 e 15 , a seguir.

Tabela 11 - Persona Joaquim

\begin{tabular}{l|l}
\hline Foto: & $\begin{array}{l}\text { Tem } 21 \text { anos, 1,71 m de altura, em geral não é uma pessoa séria ou carrancuda, } \\
\text { mas também não é sorridente. É um homem sociável, cheio de amigos a } \\
\text { sua volta e adora ir ao barzinho com eles. Mora na capital paulista, centro } \\
\text { econômico brasileiro, local perfeito para um homem que gosta de variedade } \\
\text { cultural. Não fica longe de seu smartphone e também sempre que pode, } \\
\text { está com seu laptop no colo navegando pelo Facebook e postando fotos no } \\
\text { Instagram. Tudo que pode ser resolvido pelo seu smartphone ele faz, seja por } \\
\text { chamada de voz ou qualquer aplicativo. Mas, ainda não conseguiu se habituar } \\
\text { aos serviços financeiros digitais, prefere o método clássico para guardar seu } \\
\text { dinheiro, o colchão. Nunca viajou para fora do Brasil, inclusive seu mapa de } \\
\text { viagens nacionais também não é extenso. Ao todo, visitou apenas } 9 \text { cidades } \\
\text { do Brasil com o passar do tempo. } \\
\text { Na universidade acompanhou os times de robótica nas competições e teve } \\
\text { contato com diversos tipos de robôs, como os parecidos com humanos e ani- } \\
\text { mais, com mobilidade através de rodas e também os de linha de produção. } \\
\text { Quando perguntam sua expectativa sobre robôs convivendo em sua casa, ele } \\
\text { diz que tudo bem, desde que ele execute as tarefas domésticas sempre com } \\
\text { obediência e de certa maneira, também espera que o robô seja afetivo na } \\
\text { interação. Um comportamento próximo ao de uma diarista na família. Já no } \\
\text { ambiente industrial, Joaquim acredita que os robôs são apenas ferramentas de } \\
\text { trabalho e não devem fazer nada além de executar o que lhe foi programado. }\end{array}$ \\
\hline Descrição
\end{tabular}

Fonte: $\mathrm{O}$ autor.

As Personas apresentadas nas tabelas 11, 12, 13, 14, 15 ajudaram na definição das independências condicionais entre as variáveis da rede bayesiana. Mais informações das análises feitas com base nas Personas, e também sobre sua criação, em relação a interação com o robô são apresentadas no capítulo 6. 
Tabela 12 - Persona Maria Eduarda

\begin{tabular}{l|l}
\hline Foto: & $\begin{array}{l}\text { Aos } 36 \text { anos, com 1,71 m de altura, é uma garota reservada que adora sorrir } \\
\text { em diversas ocasiões. É bem sociável, e mantém os amigos por perto. É } \\
\text { uma mulher moderna e gosta de manter seu corte de cabelo mais curto que } \\
\text { o convencional. Mora em São Bernardo do Campo, cidade da grande São } \\
\text { Paulo e gosta muito de visitar o interior de São Paulo para passar seus feria- } \\
\text { dos prolongados. Não vive sem seu celular, e no trabalho o computador é sua } \\
\text { principal ferramenta. Quando está em casa utiliza sua Smart TV para assis- } \\
\text { tir suas séries e filmes favoritos. Gostaria muito de ter um leitor de e-book } \\
\text { para evitar carregar livros pesados durante seu trajeto pelo transporte público. } \\
\text { Mesmo com essa adoção a tecnologia, empresas digitais, principalmente do } \\
\text { mercado financeiro, não a atraem. Sempre conectada através do celular, ela } \\
\text { posta tudo no Facebook, tanto de trabalho quanto de lazer. } \\
\text { Já viajou algumas vezes para os EUA, sempre a passeio com o principal des- } \\
\text { tino a Disney. Pelo Brasil, já viajou para algumas cidades fora de São Paulo } \\
\text { e deixou sua marca por todas as regiões do país. Como ela trabalha em uma } \\
\text { universidade de engenharia, já viu diversos tipos de robôs, que são utilizados } \\
\text { nas aulas. Porém, nunca teve um contato direto com eles, a não ser seu aspi- } \\
\text { rador de pó. Tanto em casa quanto no trabalho, ela espera que robôs sejam } \\
\text { capazes de realizar tarefas com eficácia, como dirigir um carro, digitar } \\
\text { planilhas, mas que ao mesmo tempo não seja capaz de substituíla. }\end{array}$ \\
\hline Fonana
\end{tabular}

Fonte: $\mathrm{O}$ autor.

\subsection{TOMADA DE DECISÃO: CLASSIFICADOR BAYESIANO}

Neste momento todos os passos necessários para identificar as Personas, ações do robô e as necessidades do projeto foram realizados. As últimas variáveis selecionadas para compor a rede Bayesiana para classificação do perfil do usuário, representado pela Persona, são as comportamentais. As variáveis comportamentais neste ponto estão ligadas as possíveis experiências que o usuário pode sentir na interação. Dentre as variáveis apresentadas na seção 5.1 são selecionadas as variáveis conforto e medo. As duas variáveis conseguem representar grande parte das demais variáveis comportamentais. Neste momento, a forma de identificar as variáveis de conforto e medo, é através da declaração do usuário durante o teste e também nas respostas do questionário pós teste. A partir desse ponto, têm-se todas as variáveis definidas e é necessário definir a estrutura da rede Bayesiana. Na sequência será apresentado cada conjunto de nós e suas dependências condicionais para a criação da estrutura da rede Bayesiana de classi- 
Tabela 13 - Persona Alfredo

\begin{tabular}{l|l}
\hline Foto: & $\begin{array}{l}\text { Aos } 24 \text { anos, rapaz de estatura normal, por volta de 1,75m, está sempre com } \\
\text { um belo sorriso no rosto, faça chuva ou faça sol. Sempre tem pessoas a sua } \\
\text { volta, gosta de contar piadas e fazer todos sorrirem. Morador da cidade } \\
\text { de São Bernardo do Campo, mas sempre que pode vai para o litoral paulista } \\
\text { visitar os pais e curtir uma praia. Usa computador para fazer os trabalhos da } \\
\text { faculdade e passa grande parte do seu tempo no celular. Não possui ser- } \\
\text { viços financeiros digitas, pois ainda não conseguiu a aprovação do cadastro. } \\
\text { Quando se trata de internet banking, acredita que o seu computador é mais } \\
\text { seguro que o uso de celular. } \\
\text { Alfredo vive antenado nas redes sociais, como Twitter, Instagram e Facebook. } \\
\text { Ajudam ele a ficar conectado com as últimas notícias e eventos a sua volta. } \\
\text { Tem um sonho de viajar para o exterior, mas isso ainda não foi possível, em } \\
\text { compensação pelo Brasil já visitou mais de } 30 \text { cidades, a maioria na região } \\
\text { Sudeste. Na universidade, através do curso de engenharia de automação, teve } \\
\text { contato com robôs de fábrica e móveis conforme os laboratórios das disci- } \\
\text { plinas ocorriam. Quando perguntam a Alfredo o que ele espera de um robô } \\
\text { doméstico e também um robô no trabalho, ele diz que robôs devem executar } \\
\text { as tarefas propostas de maneira eficiente e que sua interação seja toda } \\
\text { por comando de voz. }\end{array}$ \\
\hline Demato
\end{tabular}

Fonte: $\mathrm{O}$ autor.

ficação, dado as especificações do projeto de interação humano-robô, de acordo com o método apresentado no capítulo 4.

Os nós raízes da rede Bayesiana são compostos pelas 5 Personas apresentadas na seção 5.11. Elas são escolhidas como raiz por que representam os perfis de usuários que devem ser classificados durante a aproximação do robô. A probabilidade do usuário em interação ser ou não aquela Persona é determinada, pela quantidade de pessoas que pertencem ao grupo encontrado pelo QG-SIM. Como são nós raízes, não existem nenhuma evidência para compor seu valor de probabilidade, apenas a quantidade de pessoas de cada grupo. As equações 3, 4, 5, 6 e 7 representam a probabilidade de cada uma das Personas obtidas. 
Tabela 14 - Persona Danielo

\begin{tabular}{l|l}
\hline Foto: & $\begin{array}{l}\text { Com } 27 \text { anos de idade, 1,83m, Danielo está sempre na academia para treinar } \\
\text { com seus amigos. Mora em São Bernardo do Campo, e utiliza seu computa- } \\
\text { dor para fazer seu trabalho e o celular para manter contato com seus amigos. } \\
\text { Nunca quis saber de leitores de e-book, pois acha sua tecnologia sem uti- } \\
\text { lidade nos dias atuais. A sua única rede social é o Facebook. Ele acha que } \\
\text { já toma tempo o suficiente e não precisa de outras para ver a mesma coisa. } \\
\text { Danielo é um rapaz que já viajou bastante. Já visitou } 3 \text { países latinos e no } \\
\text { Brasil visitou mais de } 90 \text { cidades, concentradas em sua grande parte, na re- } \\
\text { gião Sudeste. O contato com robôs é limitado e restrito a robôs de fábrica. } \\
\text { Em casa ele acredita que o robô será parecido com seres humanos para } \\
\text { fazer as atividades domésticas, e no trabalho substituirão seres humanos } \\
\text { em trabalhos repetitivos, como nas fábricas e linha de produção. }\end{array}$ \\
\hline Danielo
\end{tabular}

Fonte: $\mathrm{O}$ autor.

$$
\begin{aligned}
& P(\text { alfredo }) \\
& P(\text { danielo }) \\
& P(\text { manuel })
\end{aligned}
$$

As variáveis são nomeadas com letras minúsculas, pois são variáveis com apenas dois valores representando ser ou não ser. Essa notação segue a convenção apresentada por Russell e Norvig (2002).

Seguindo com a construção da rede, cada nó interno foi considerado com base nas variáveis criadas a partir das heurísticas de interação humano-robô, das ações do robô e também do contexto de uso e ambiente de teste. As independências condicionais entre cada nó foram observadas pelos comentários de cada usuário durante os testes. O processo de criação dos nós é detalhado na sequência. A inclusão dos nós é feita com base nas variáveis apresentadas na tabela 5 .

O nó Proximidade leva em consideração os espaços sociais definidos por Hall (1969). O domínio foi simplificado para \{perto, longe\}, pois durante os testes pilotos a reação do usuário era a mesma entre as regiões íntima e pessoal (perto) e as regiões social e pública (longe). A 
Tabela 15 - Persona Manuel

\begin{tabular}{|c|c|}
\hline \multirow{2}{*}{\multicolumn{2}{|c|}{ Foto: }} \\
\hline & \\
\hline Descrição: & $\begin{array}{l}\text { Aos } 33 \text { anos, } 1,85 \mathrm{~m} \text {, Manuel um professor universitário sempre sorridente. } \\
\text { Seus alunos sempre o procuram para esclarecer dúvidas e pedir conselhos. } \\
\text { Mora em São Bernardo do Campo, próximo ao seu local de trabalho, por que } \\
\text { adora o conforto de ir em sua casa poder almoçar uma comida fresca. Acredita } \\
\text { que tem uma melhor qualidade de vida assim. Não é muito fã de tecnologia } \\
\text { de ponta, então fica contente em ter seu computador, onde resolve tudo } \\
\text { que pode. Digitalmente, considera-se antissocial e não mantém cadastro } \\
\text { em nenhuma rede social. } \\
\text { Já visitou países pela Europa, África, América do Norte e do Sul. No Brasil, } \\
\text { seu foco de visitar está na região Sudeste, principalmente o estado de Minas } \\
\text { Gerais. No total já percorreu mais de } 62 \text { cidades pelo país. Como professor, } \\
\text { sua linha de pesquisa principal de estudos é a robótica, fazendo com que tenha } \\
\text { contato com todos os tipos de robôs. Em casa, pensa em ter um robô para } \\
\text { atender suas necessidades, assim como no trabalho. Porém, o robô no tra- } \\
\text { balho deve atender também as necessidades e expectativas da empresa. }\end{array}$ \\
\hline
\end{tabular}

Fonte: $\mathrm{O}$ autor.

dependência condicional foi aplicada de acordo com a declaração explícita entre os perfis que sentiram algum desconforto com a aproximação do robô. A equação 8 define o cálculo de probabilidade condicional para a variável aleatória Proximidade.

$$
P(\text { proximidade|joaquim, alfredo, danielo })
$$

A próxima variável aleatória inserida é a Posição da pessoa no ambiente. O domínio dessa variável é determinado por \{sentado, em pé\}. Ela foi observada durante a prova de reconhecimento de pessoas e aproximação do robô na RoboCup de 2016. Nesse cenário, as pessoas que estavam sentadas ficavam bem desconfortáveis com a aproximação do robô, principalmente com relação ao seu manipulador. Nos testes pilotos, a situação demonstrou-se a mesma. As pessoas que estavam sentadas demonstravam um comportamento mais apreensivo do que as em pé. A equação 9 apresenta o cálculo de probabilidade condicional para a variável Posicao.

$$
P(\text { posicao|joaquim, maria_eduarda,alfredo,danielo, manuel) }
$$

As 4 próximas variáveis aleatórias descritas são referentes a ações do robô. Todos os 4 conjuntos são importantes na interação social e geram diferentes reações aos perfis de usuários. 
Um ponto interessante a ser ressaltado é que cada Persona mapeada, ficou atenta durante a interação em apenas algumas das variáveis. As 4 variáveis são Expressão Facial (equação 10), Gestos (equação 11), Estilo da Fala (equação 12) e Velocidade (equação 13). Seus respectivos domínios estão descritos na tabela 5 .

$$
\begin{gathered}
P(\text { face } \mid \text { joaquim,maria_eduarda, alfredo,danielo, manuel }) \\
P(\text { gestos } \mid \text { maria_eduarda, alfredo,danielo, manuel }) \\
P(\text { fala } \mid \text { joaquim, alfredo,danielo, manuel }) \\
P(\text { velocidade } \mid j o a q u i m, \text { maria_eduarda })
\end{gathered}
$$

A partir da variável Gestos, observou-se que quando ocorreu o toque do robô na pessoa, gerou uma situação de medo. A variável toque é mapeada com a dependência condicional da variável Gestos (equação 14). Seu domínio é binário, $\{$ toque, $\neg$ toque $\}$.

$$
P(\text { toque|gestos })
$$

Cada heurística apontada na seção 5.10.1 gerou um nó que representa uma variável aleatória da rede Bayesiana. Todas as heurísticas utilizadas, possuem relação com os comportamentos do robô durante os testes de interação e também com as informações feitas pelos usuários. A lista a seguir mostra as heurísticas e as nomeações como variáveis aleatórias da rede Bayesiana.

a) Visibilidade do estado do sistema - estado_robo (equação 15);

b) Uso de sugestões naturais - natural (equação 16);

c) Síntese do sistema e interface - síntese (equação 17);

d) Ajudar o usuário a reconhecer, diagnosticar, e recuperar de erros - ajudar (equação 18).

$$
\begin{gathered}
P(\text { estado_robo|joaquim, alfredo, manuel }) \\
P(\text { natural } \mid \text { fala, gestos }) \\
P(\text { sintese } \mid \text { fala })
\end{gathered}
$$$$
P(\text { ajudar } \mid \text { maria_eduarda,alfredo })
$$ 
Por fim, são definidas as variáveis aleatórias chamadas de nós evidências da rede Bayesiana. Esses nós correspondem ao sentimento das pessoas durante a interação com o robô. Esses sentimentos são declarados pelas pessoas durante a interação de acordo com o comportamento do robô. A composição das relações com esses nós foi dada pela observação dos testes e também das declarações realizadas através do questionário pós interação. As três variáveis aleatórias são conforto 19, desconforto 20 e medo 21 .

$$
\begin{gathered}
P(\text { conforto } \mid \text { proximidade, face, estado_robo, natural }, \text { sintese }) \\
P(\text { desconforto } \mid \text { posicao, face }, \text { estado_robo, ajudar, natural }) \\
P(\text { medo } \mid \text { velocidade, face, toque })
\end{gathered}
$$

As variáveis conforto e desconforto estão separadas, pois em alguns casos existiram pequenas diferenças que em uma mesma ação do robô, alguns usuários sentiram conforto e desconforto ao mesmo tempo. Por exemplo, ao se aproximar o robô chegou muito perto o que gerou o desconforto já que o usuário estava sentado, mas a expressão facial apresentada pelo robô no momento deixou ele tranquilo e confortável, mesmo não tendo como escapar da frente do robô (vide capítulo 6).

A figura 17 apresenta a estrutura completa da rede Bayesiana criada ao longo dessa seção.

A rede Bayesiana da figura 17 funciona da seguinte maneira, são fixados os valores de evidência nos nós evidências (amarelos) e nos nós internos (azuis). Com base nas evidências apresentadas, a rede responde a probabilidade de ser cada uma das Personas que compõem os nós raízes (verdes). A partir da classificação é possível identificar qual o perfil do usuário, em interação com o robô. É importante ressaltar que a classificação do usuário é feita com base em sua experiência, pois é o principal interessado na interação com o robô. A grande preocupação em manter o foco no ser humano é por que ele é o mais interessado na interação com o sistema. A tomada de decisão para melhorar a experiência do usuário a partir da classificação do perfil do usuário pelo robô não faz parte do escopo desta tese. Porém nas seções a seguir são apresentados os passos para definir os valores de probabilidades condicionais, consumir, extrair conhecimento e evoluir o classificador a partir da base apresentada nessa seção.

\subsubsection{Definindo os valores de probabilidades condicionais}

Com a estrutura da rede Bayesiana definida, antes de utilizá-la para classificar as Personas, é necessário definir as tabelas com os valores das probabilidades condicionais para cada variável. Para construir as tabelas de probabilidades condicionais (TPC), é feito a análise das respostas nos questionários e sobre as anotações realizados durante o teste de interação. Durante o processo de análise é identificado a frequência dos eventos que envolvem cada variável. 
Figura 17 - Rede bayesiana construída para auxiliar no diagnóstico e avaliação da experiência do usuário na interação com o robô.

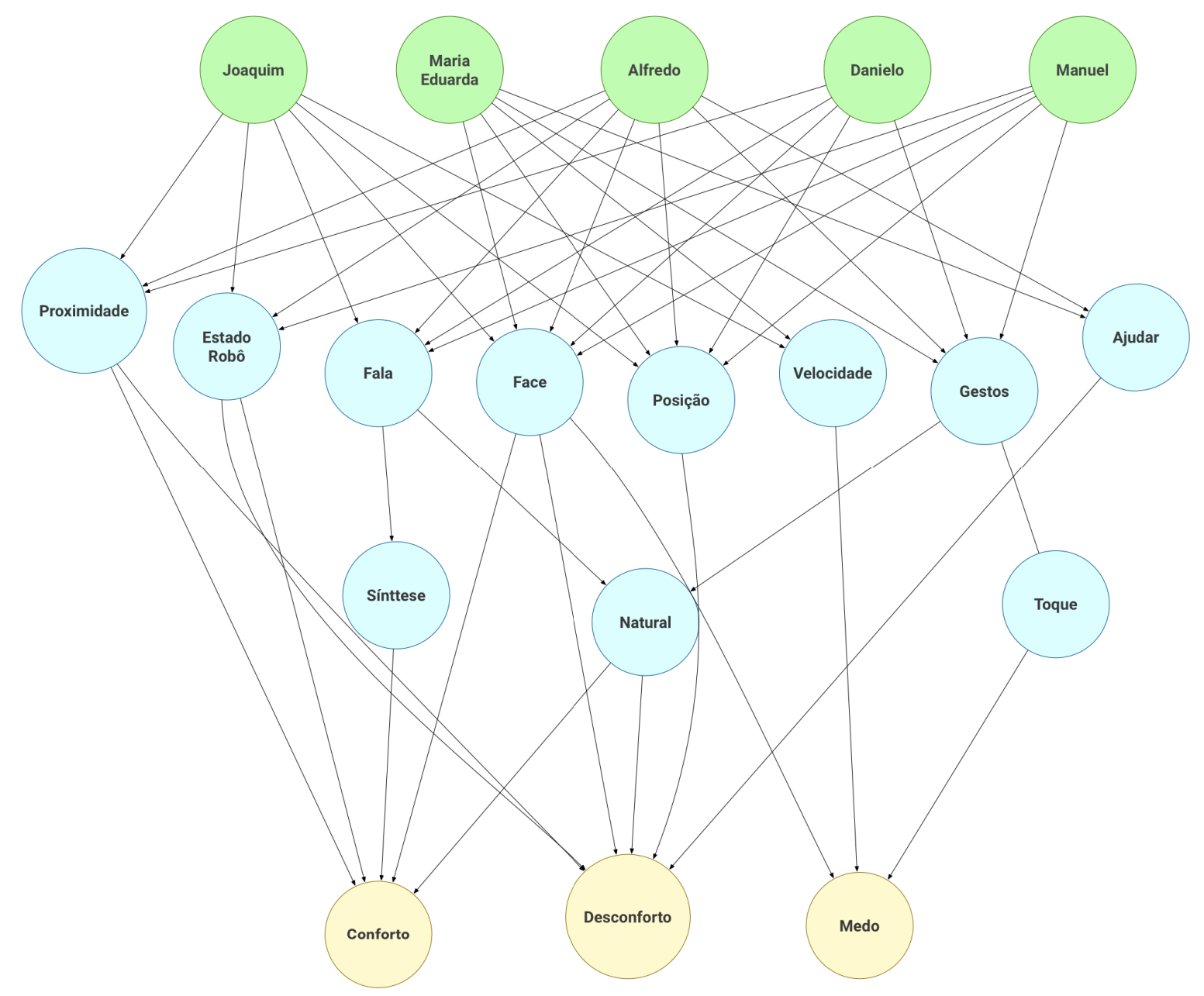

Fonte: Autor.

Nesse momento conseguimos estipular o valor de cada uma das variáveis, como por exemplo, a Persona Danielo representa 1 participante de 39 no total. Sendo assim, a probabilidade de ser ele é de $2,56 \%$. O seu complemento deve somar uma probabilidade total de $100 \%$. No caso a probabilidade de não ser a Persona Danielo é de 97,44\%. Para nós sem dependência condicional, como no caso das Personas, esse cálculo é mais concreto. Contudo, quando mais profundo o nó na rede Bayesiana, e mais condicionado a outras variáveis, o cálculo para conseguir definir as probabilidades em $100 \%$ torna-se mais complicado de atingir.

Então, a partir da contabilidade dos eventos utilizam-se as equações de teoria de probabilidade definidas para encontrar os valores de cada um dos domínios da variáveis da rede Bayesiana. Todos os valores devem ser normalizados para manter a somatória das probabilidades igual a 1, ou seja, igual a $100 \%$. A partir do cálculo é possível determinar os valores de consultas e utilizar a rede Bayesiana para sua classificação. Dependendo da frequência encontrada, após a normalização a diferença pode ser pequena, principalmente pelo número de 
variáveis condicionais existentes. Esse problema pode ser solucionado através de mais experimentos e um refinamento da TPC. Os valores de probabilidades condicionais de cada variável são apresentados no apêndice 7 dessa tese. Na sequência, o processo de consumo da rede Bayesiana é descrito para auxiliar na classificação do perfil do usuário como Persona.

\subsubsection{Executando a classificação da Persona}

Para classificar a Persona, é necessário implementar o cálculo das probabilidades condicionais no robô. Com a implementação concluída é realizado a interação do robô, onde é capturado as evidências das variáveis que auxiliam a determinar os valores de cada variável da camada interna e também da camada de evidência da rede Bayesiana.

O resultado a partir das evidências identificadas durante a interação, é a probabilidade de cada Persona ser enquadrada pelo perfil daquele usuário. Para definir a Persona, deve-se identificar qual delas têm a maior probabilidade de ser classificada como similar ao perfil do usuário. Nessa tese, para efeito de visualização da rede Bayesiana, utilizou-se um programa chamado SamIam ${ }^{9}$. Ele é capaz de criar e executar uma rede Bayesiana através de uma interface visual, facilitando identificar o comportamento dela. A figura 18 apresenta a interface do programa SamIam.

Figura 18 - Rede bayesiana implementada no programa SamIam.

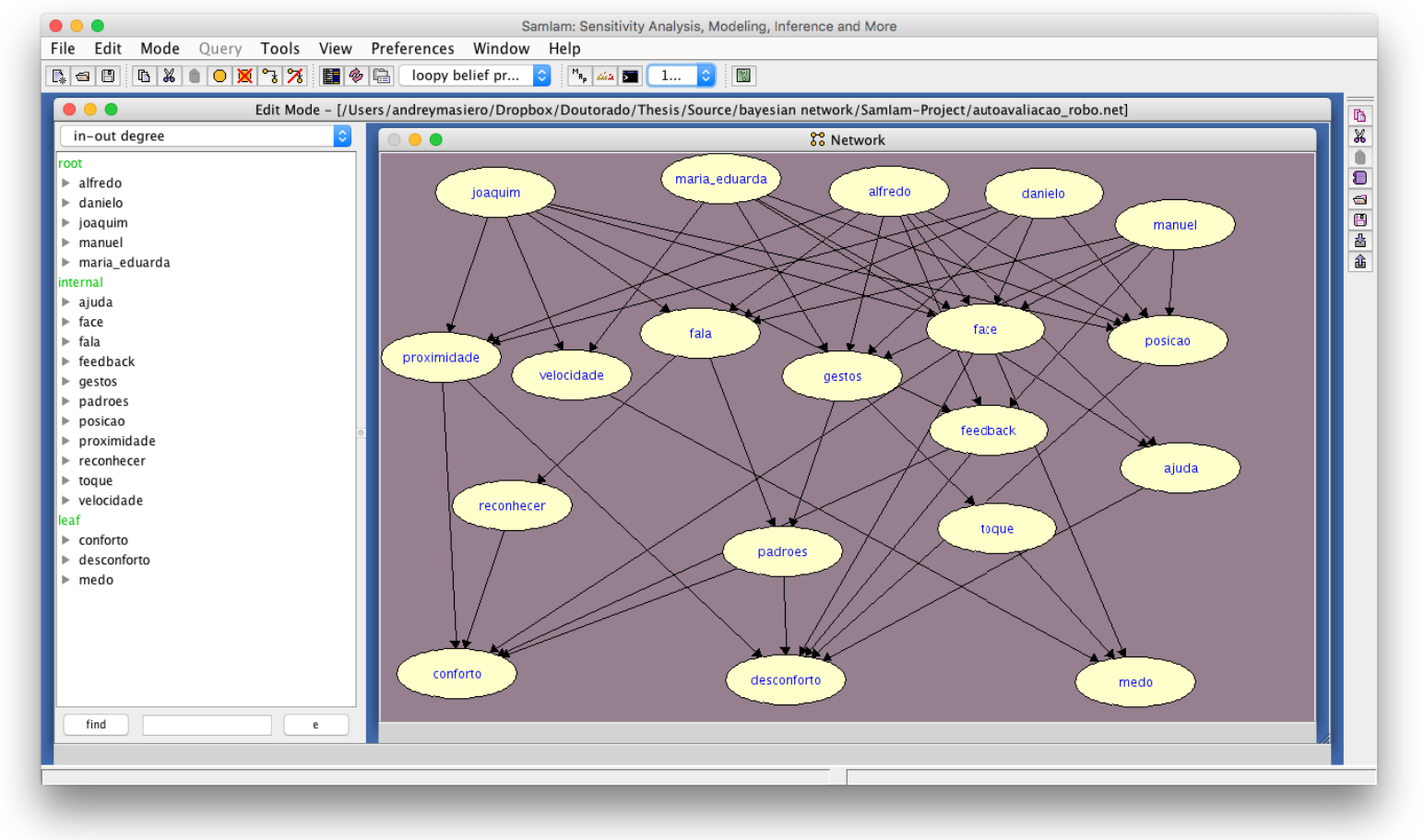

Fonte: Autor.

\footnotetext{
${ }^{9}$ http://reasoning.cs.ucla.edu/samiam/
} 
Na figura 18 é apresentado a implementação da rede Bayesiana estrutura na figura 17. Nele é possível monitorar as variáveis que representam as Personas e, ao alterar os valores das variáveis de evidência e saber qual o perfil com maior probabilidade. As análises e detalhes sobre os testes são discutidos no capítulo 6 . 


\section{RESULTADOS E DISCUSSÕES}

Durante a aplicação no estudo de caso do método centrado no usuário para construção de uma interação entre o ser humano e o robô, foi notado alguns pontos fortes da teoria. Para discussão desses pontos será realizado uma análise do estudo, de acordo com as premissas apresentadas no método e também algumas questões sociais encontradas na interação humanorobô aplicada no teste.

No estudo de caso, observou se durante a interação social, informações sobre a percepção do usuário e ações do robô para determinar o perfil do indivíduo. Também como a experiência de vida e a cultura do usuário podem influenciar na interação. Outro ponto observado é a possível existência de diferença de interação do robô para pessoas sentadas ou em pé e entre gêneros diferentes. As variáveis de validação, para este caso, foram conforto e medo do usuário em relação a interação e aproximação do robô em ambiente doméstico simulado.

O contexto de uso utilizado para os testes e desenvolvimento do projeto foi inspirado em cenários da RoboCup @ home (BEEK et al., 2015), competição mundial de robôs de serviço domésticos. Apesar de restringir o contexto a uma das tarefas da competição, este abrange uma quantidade considerável de habilidades do robô para conseguir atender a tarefa como um todo.

Os perfis de teste foram selecionados de acordo com o publicado no projeto enviado ao comitê de ética sobre o registro CAAE: 70057117.0.0000.5508, e apresentado na seção 5.5. Os participantes são jovens e adultos com idade entre 18 e 60 anos. Para os testes piloto de interação, 39 participantes foram selecionados. Essa foi base para criação das Personas que auxiliaram na construção do classificador Bayesiano do perfil do usuário. A tabela 16 apresenta as informações demográficas básicas sobre os usuários selecionados para realizar os testes piloto.

A tabela 16 apresenta as informações declaradas sobre todos os participantes do teste piloto utilizado na etapa de construção do projeto de interação humano-robô. Pode-se identificar os limites das variáveis dos participantes como, a idade mínima apresentada é de 18 anos e a máxima de 42 anos. A relação entre altura das pessoas, a menor estatura foi de 1,51 m contra 1,87 m da maior. Quanto ao gênero, de 39 participantes temos uma divisão de 29 homens e 10 mulheres na amostra. Todos estão distribuídos entre funcionários e alunos da instituição de ensino. As informações apresentadas na tabela 16 são referentes as características demográficas e algumas com relação ao comportamento do usuário. Por exemplo, no caso de feição e se o usuário é sociável. Elas auxiliam na construção do perfil demográfico e comportamental do usuário. Todas essas informações obtidas através do questionário pré experimento são confrontadas com as informações do questionário pós teste para análise da interação.

Os testes piloto têm o foco em entender como os participantes reagiram com o robô em um cenário de interação doméstico durante a aproximação do robô. Além de avaliar as questões estruturais do robô e também de comportamento, uma vez que o robô é totalmente autônomo e não houve o uso do método Wizard of $O z$. A validação da reação dos usuários é com base nos sentimentos deles durante a interação, onde foi traduzido em conforto e medo, 
Tabela 16 - Perfis dos 39 usuários que realizaram o teste piloto.

\begin{tabular}{|c|c|c|c|c|c|c|c|}
\hline Idade & Altura & Gênero & Feição & Sociável? & $\begin{array}{c}\text { Óculos } \\
\text { de Grau? }\end{array}$ & $\begin{array}{c}\text { Cabelo } \\
\text { Comprido? }\end{array}$ & Etnia \\
\hline 31 & 1.74 & Masculino & Normal & Sim & Não & Não & Branca \\
\hline 24 & 1.80 & Masculino & Sorridente & Sim & Sim & Não & Branca \\
\hline 26 & 1.70 & Masculino & Sorridente & Sim & Não & Não & Parda \\
\hline 19 & 1.70 & Masculino & Normal & Não & Não & Não & Branca \\
\hline 20 & 1.68 & Feminino & Sorridente & Sim & Sim & Sim & Branca \\
\hline 20 & 1.63 & Feminino & Normal & Sim & Sim & Não & Parda \\
\hline 20 & 1.68 & Masculino & Sorridente & Sim & Sim & Não & Branca \\
\hline 20 & 1.80 & Masculino & Sorridente & Sim & Sim & Não & Branca \\
\hline 34 & 1.85 & Masculino & Normal & Sim & Não & Não & Branca \\
\hline 22 & 1.61 & Feminino & Séria/Fechada & Sim & Sim & Sim & Preta \\
\hline 23 & 1.80 & Masculino & Séria/Fechada & Não & Sim & Não & Branca \\
\hline 20 & 1.65 & Masculino & Sorridente & Sim & Sim & Não & Branca \\
\hline 24 & 1.68 & Masculino & Séria/Fechada & Sim & Não & Não & Branca \\
\hline 20 & 1.75 & Masculino & Sorridente & Não & Sim & Não & Branca \\
\hline 21 & 1.80 & Masculino & Normal & Não & Não & Não & Branca \\
\hline 22 & 1.72 & Masculino & Sorridente & Sim & Sim & Não & Branca \\
\hline 26 & 1.75 & Masculino & Sorridente & Sim & Não & Não & Branca \\
\hline 30 & 1.59 & Feminino & Normal & Sim & Não & Sim & Parda \\
\hline 27 & 1.83 & Masculino & Normal & Sim & Não & Não & Parda \\
\hline 24 & 1.78 & Masculino & Normal & Sim & Não & Não & Preta \\
\hline 42 & 1.78 & Masculino & Sorridente & Sim & Não & Sim & Branca \\
\hline 33 & 1.85 & Masculino & Sorridente & Sim & Sim & Não & Branca \\
\hline 24 & 1.70 & Masculino & Normal & Sim & Não & Não & Branca \\
\hline 24 & 1.76 & Masculino & Normal & Sim & Não & Não & Branca \\
\hline 18 & 1.63 & Masculino & Sorridente & Sim & Sim & Sim & Branca \\
\hline 33 & 1.75 & Masculino & Sorridente & Sim & Não & Não & Branca \\
\hline 22 & 1.67 & Feminino & Sorridente & Sim & Não & Não & Branca \\
\hline 22 & 1.67 & Masculino & Séria/Fechada & Sim & Não & Não & Preta \\
\hline 21 & 1.51 & Feminino & Normal & Não & Sim & Sim & Amarela \\
\hline 19 & 1.73 & Masculino & Normal & Sim & Não & Não & Branca \\
\hline 34 & 1.66 & Feminino & Sorridente & Não & Sim & Sim & Amarela \\
\hline 39 & 1.77 & Masculino & Normal & Sim & Não & Não & Branca \\
\hline 22 & 1.63 & Feminino & Normal & Sim & Não & Sim & Branca \\
\hline 19 & 1.80 & Masculino & Sorridente & Não & Não & Não & Branca \\
\hline 20 & 1.75 & Masculino & Normal & Sim & Não & Não & Branca \\
\hline 36 & 1.68 & Feminino & Normal & Sim & Não & Não & Branca \\
\hline 20 & 1.87 & Masculino & Normal & Sim & Sim & Não & Branca \\
\hline 40 & 1.74 & Feminino & Normal & Sim & Sim & Não & Branca \\
\hline 23 & 1.82 & Masculino & Normal & Sim & Não & Não & Branca \\
\hline
\end{tabular}

Fonte: $\mathrm{O}$ autor.

através do questionário pós teste. Confrontando as informações de ambos questionários, foram gerados gráficos que auxiliam na visualização do perfil dos usuários que participaram do teste. 
Testes estatísticos foram realizados com a intenção de validar as informações apresentadas nos gráficos, sobre os perfis do usuário.

A figura 19 apresenta a relação das informações sobre gênero dos participantes e o quanto se sentiram confortáveis na interação com o robô sendo o menor valor para totalmente desconfortável e o oposto para totalmente confortável.

Figura 19 - Conforto por gênero.

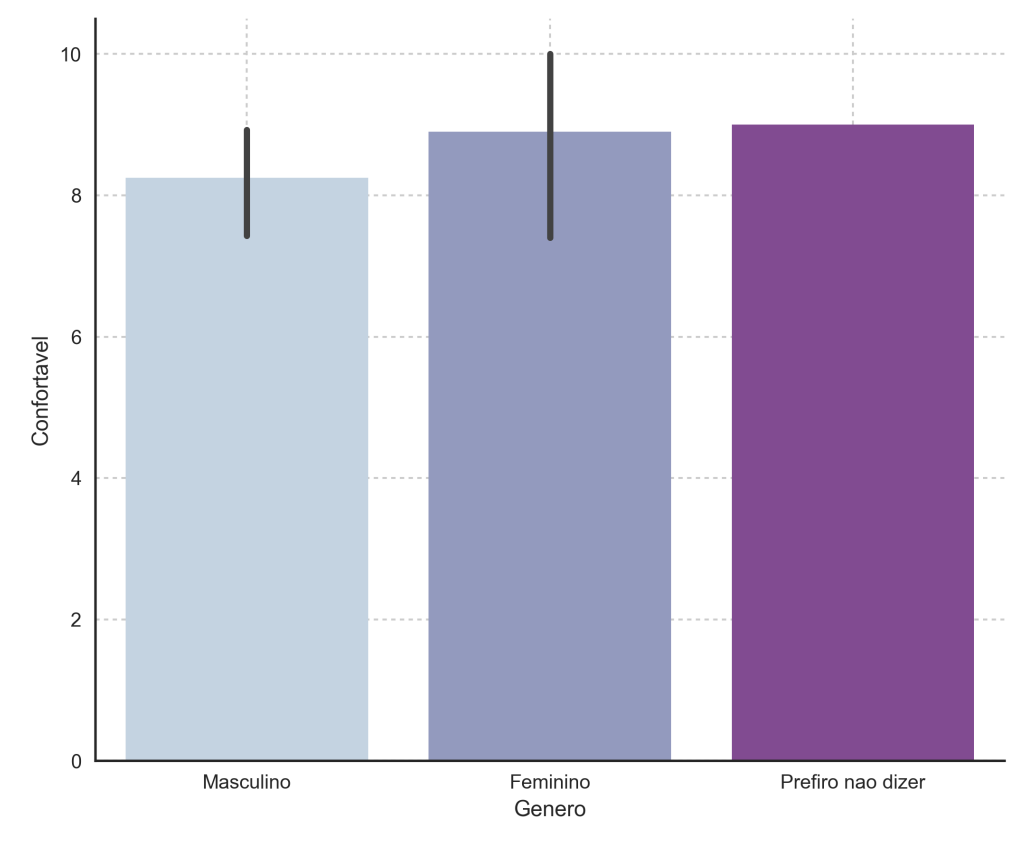

Fonte: $\mathrm{O}$ autor.

Pode-se observar na figura 19 que houve um equilíbrio entre os gêneros com relação ao conforto na aproximação do robô. Na média os homens ficaram 8.25 confortável na escala Likert. O desvio padrão para o gênero masculino é de 1.9933. As mulheres tiveram a média 8.9 e o desvio padrão em 2.0224. Isso ocorreu em grande parte devido a exibição das expressões faciais do robô, de acordo com o observado durante os testes pelo especialista e conferência dos vídeos gravados durante a seção. Ao aplicar o teste $\mathrm{T}$ de Student, obtêm-se o valor $\mathrm{p}$ igual 0.3964. Esse valor p invalida a diferença entre gêneros. Para essa amostra, não existem diferenças na interação com o robô entre homens e mulheres, contrariando algumas informações obtidas na literatura. Outra variável que é comparada é a idade dos participantes com o nível de conforto, apresentado na figura 20.

Dois participantes apresentaram um nível de desconforto, mais elevado que os demais participantes, na aproximação do robô. Um participante apresentou a idade de 20 anos e outro de 40 anos. Foram os que ficaram mais desconfortáveis com o robô, como observado na figura 20. Os demais demonstraram-se confortáveis com o robô na aproximação de uma maneira geral. Esse é um indicativo que pode ser explorado, pois o contato prévio de ambos participan- 
Figura 20 - Conforto por idade.

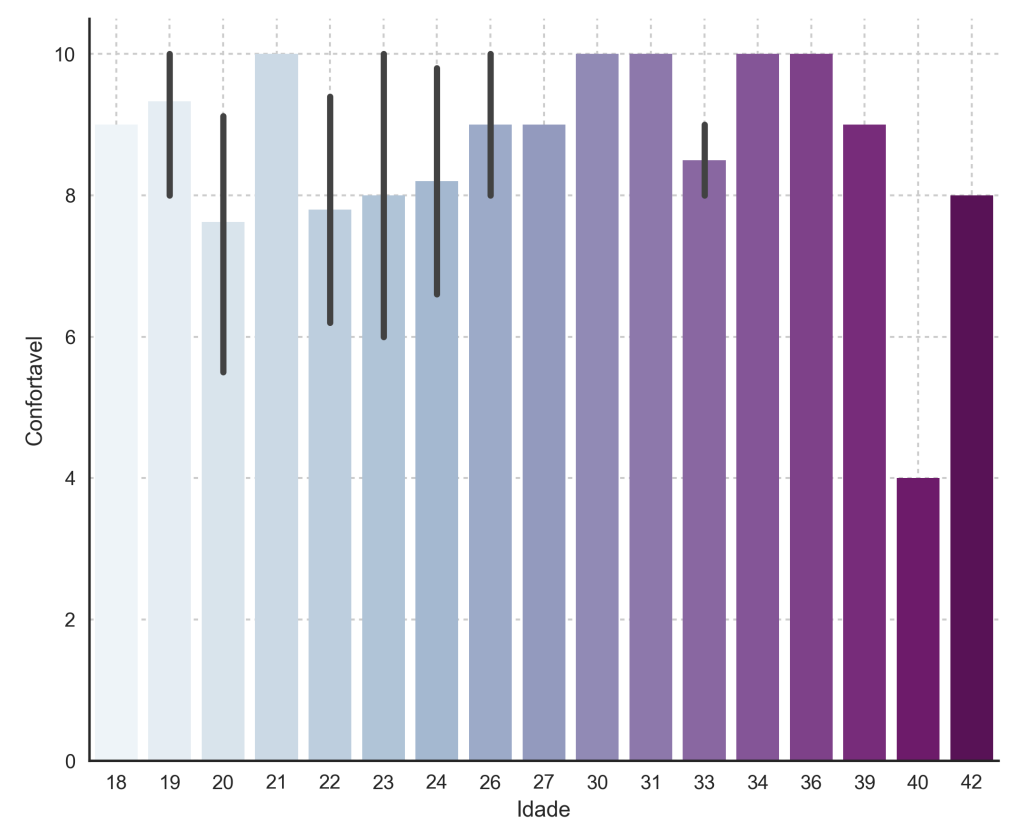

Fonte: $\mathrm{O}$ autor.

tes foi mínimo com o robô. Essa situação pode gerar uma certa resistência em interagir com robôs autônomos e por consequência seu desconforto.

Na figura 21 é apresentada a relação entre o conforto do participante e a posição dele durante a interação, sentado ou em pé.

Figura 21 - Conforto por posição de interação.

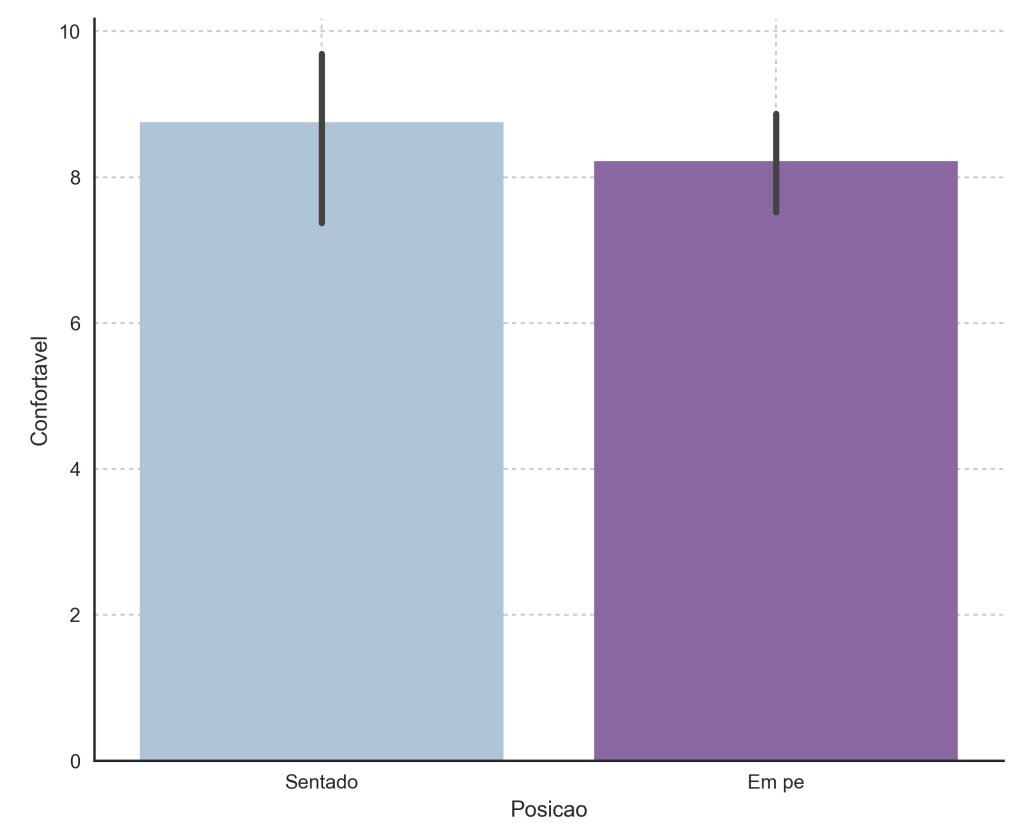

Fonte: $\mathrm{O}$ autor. 
É observado na figura 21 o oposto observado na competição da RoboCup@ Home. Na competição, as pessoas sentadas sentiram-se com maior desconforto durante a aproximação do robô. Nos testes, as pessoas que estavam sentadas durante a interação com o robô sentiram-se tão confortáveis quanto as pessoas que estavam em pé. Na média as pessoas em pé apresentaram um grau de conforto igual a 8.2174 e desvio padrão de 1.6407. Já as pessoas sentadas mantiveram uma média de 8.75 de grau de conforto, com desvio padrão 2.3848. Essa diferença pequena de conforto ocorreu, pois o robô tocou no braço e barriga de alguns participantes que estavam em pé quando esticou o manipulador para chamar a atenção deles. O fenômeno do toque é um ponto de atenção que deve ser tratado em uma nova iteração do ciclo de desenvolvimento do projeto, como uma futura evolução no controle do manipulador. Isso por que o robô é totalmente autônomo e sua aproximação gerou uma confiança frágil. Porém, ao aplicar o teste $\mathrm{T}$ de Student, obtêm se o valor $\mathrm{p}$ igual a 0.4261 . Esse valor $\mathrm{p}$ informa que ambas posições não possuem um valor estatístico relevante para uma diferença entre as amostras das diferentes posições.

Algumas situações durante o cenário de interação causaram medo, como por exemplo, o manipulador tocando o participante no quadril ou barriga. E na mesma situação, o usuário ficou confortável ao ver a expressão facial amigável do robô, esboçando um sorriso. Assim, a mesma análise para o conforto do usuário, foi realizada para a declaração de medo. Entretanto, quando existe um canal múltiplo de saída, seria interessante investigar a análise como uma tarefa temporal, onde cada ação é independente quando analisada de maneira separada, mas são dependente quando é inserido o fator temporal.

$\mathrm{Na}$ escala da pergunta sobre medo do robô, o menor valor corresponde a totalmente com medo (valor 0 da escala) e o oposto corresponde a totalmente sem medo (valor 10 da escala). A figura 22 apresenta a relação entre o medo e o gênero do participante.

Para a relação de medo e gênero, o que observa-se na figura 22 que a diferença entre os gêneros é ínfima. Na média as mulheres obtiveram 8.4 pontos na escala Likert de medo, com desvio padrão de 2.1071. Enquanto isso, os homens ficaram com a média de 8.1429 e desvio padrão de 2.6010. Apesar dessa relação nem sempre ser diretamente proporcional, o resultado foi de acordo com o esperado, após as análises sobre o conforto. A indiferença entre gênero aqui é comprovada através de um teste T de Student, que obteve-se um valor p de 0.7857 . Na sequência é feita a análise com base na relação medo e idade, demonstrada na figura 23.

Um participante na faixa etária de 40 anos, apresentou o maior índice de medo, conforme figura 23. Os participantes com 19 anos também apresentam um valor baixo na pontuação de Likert, que indica medo na interação por parte do participante. Isso ocorreu, pois com o comportamento invasivo do robô ao aproximar para interagir, e ao movimentar a garra em direção ao participante o deixou assustado. Outro ponto observado foi que o robô ao se movimentar emite muito ruído, devido ao novo conjunto de rodas omnidirecionais.

A figura 24 compara a relação do medo declarado do usuário contra a posição dele durante a navegação do robô. 
Figura 22 - Medo por gênero.

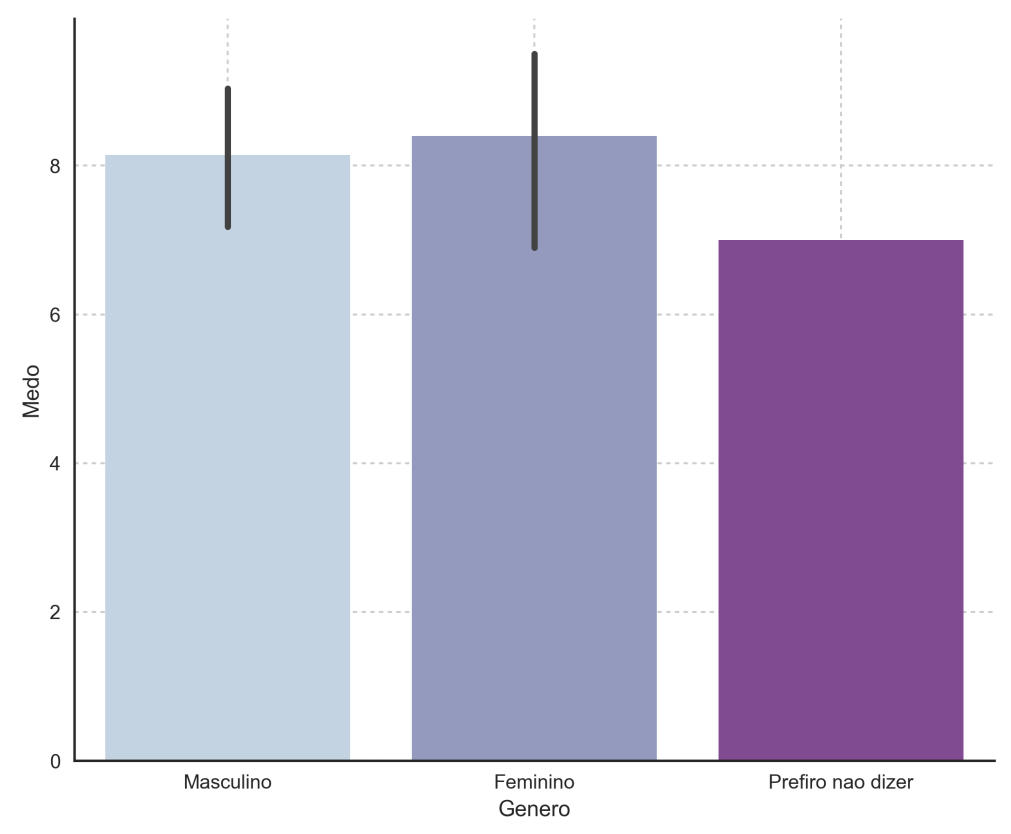

Fonte: $\mathrm{O}$ autor.

Figura 23 - Medo por idade.

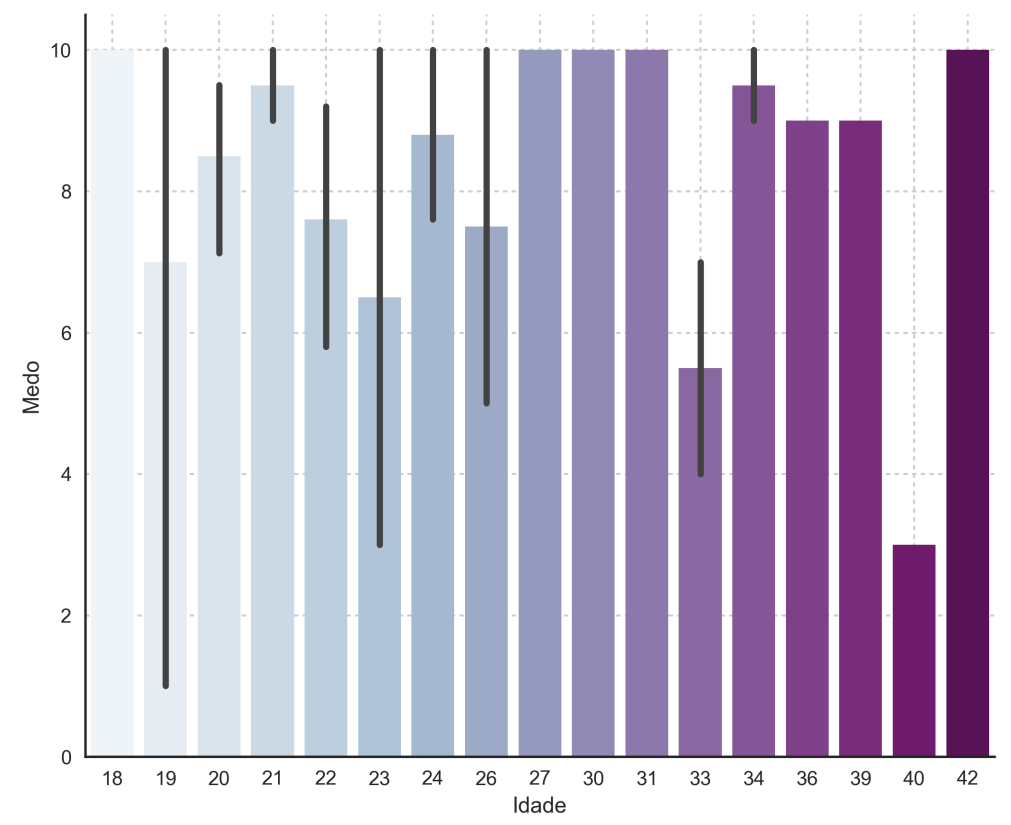

Fonte: O autor.

Assim como em relação ao conforto do usuário, os participantes que sentiram mais medo do robô estavam em pé. Os participantes sentados apresentaram uma média de 8.8750, com desvio padrão de 1.6910. Comparando, os participantes em pé tiveram 7.6957 de média e um desvio padrão de 2.7731. O manipulador é um ponto de atenção na interação, principalmente 
Figura 24 - Medo por posição de interação.

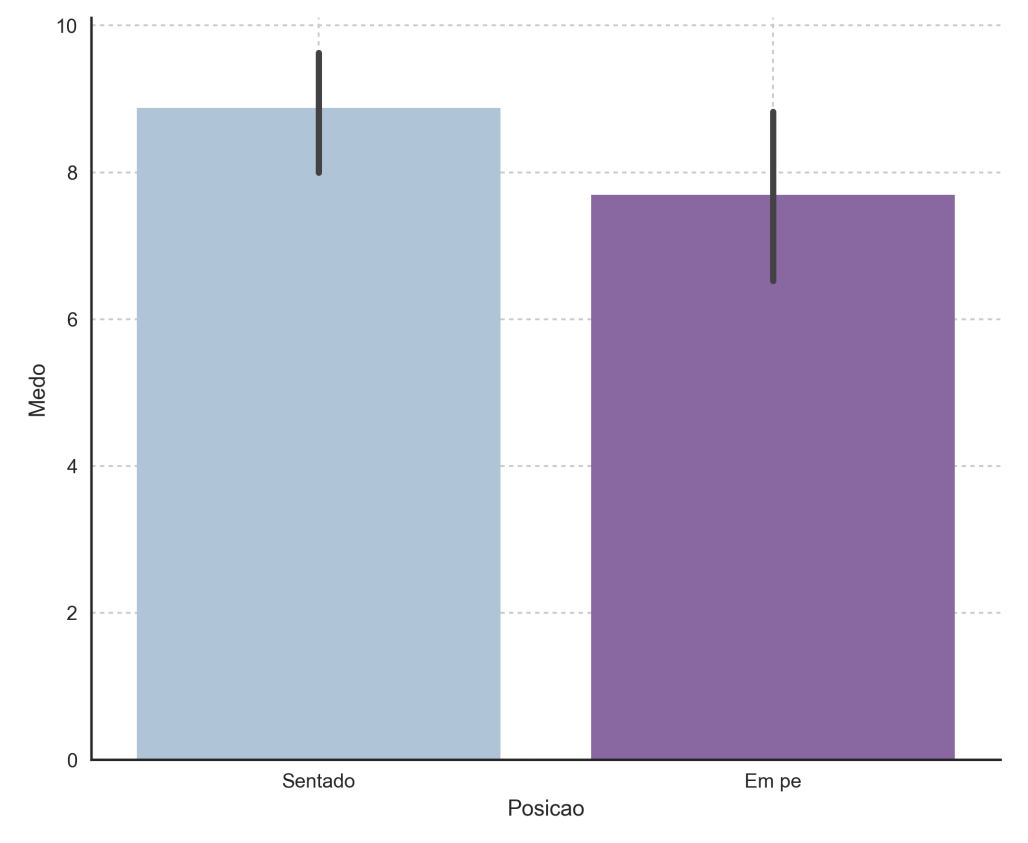

Fonte: $\mathrm{O}$ autor.

quando está dentro do espaço social pessoal ou intimo da pessoa. Os maiores índices de medo ocorreram por que o robô encostou o manipulador na pessoa, sem nenhum aviso prévio. Apesar disso, estatisticamente, não existiu um valor $\mathrm{p}$ que tornasse a diferença relevante. $\mathrm{O}$ valor $\mathrm{p}$ obtido pelo teste T de Student foi de 0.1482 .

Após as análises gerais sobre as informações coletadas, é realizado o processo para obter os grupos de perfis de usuários, conforme descrito no passo apresentado na seção 4.2.3. Para obter os grupos de perfis, utilizou-se o algoritmo de agrupamento por similaridade QGSIM. Foram testados três valores $Q$, que determinam a similaridade mínima do grupo, para determinar-los. Os valores utilizados foram $0.6,0.7$ e 0.8 . O valor 0.6 resultou em 3 grupos, porém um dos grupos manteve $90 \%$ dos perfis e os outros $10 \%$ foram distribuídos entre os dois grupos restantes. $\mathrm{O}$ valor $Q=0.6$ apresentou resultado muito generalizado e que não condiz com os perfis que realizaram os testes. Essa é uma análise a qual o especialista deve realizar quando receber o resultado do algoritmo. É isso que determinará a necessidade ou não de realizar um agrupamento com novos valores de $\mathrm{Q}$.

Na sequência dos testes com o algoritmo, é aplicado o valor de 0.8 de similaridade para o algoritmo, onde 7 grupos foram encontrados. Nessa situação, os grupos ficaram bem específicos, sendo que 4 dos 7 grupos eram compostos por apenas 1 pessoa. Dessa maneira, é possível comprovar que o resultado gerado é muito especializado. Elevar o grau de similaridade nesse ponto, provavelmente serão encontrados mais grupos com apenas uma pessoa. Esse não é o objetivo da técnica de Personas, pois ela visa com um número pequeno de perfis, atingir um grande número de usuários. Quando o agrupamento fica muito específico a ponto de ter 
apenas um usuário por grupo, a técnica perde seu efeito. É como se a análise fosse feita pessoa a pessoa. Então este resultado também foi desconsiderado.

O valor intermediário, 0.7, foi escolhido. Ele resultou em 5 grupos. Um grupo com 21 perfis, que resultou na Persona Joaquim (vide tabela 11). Um grupo com 7 pessoas para Persona Maria Eduarda (vide tabela 12). Outro grupo com 9 pessoas deu origem a Persona Alfredo (vide tabela 13). As outras duas Personas foram criadas com base em dois grupos de 1 pessoa. Apesar de serem formados por apenas 1 pessoa, algumas características foram totalmente descriminante. A Persona Manuel (vide tabela 15), por exemplo, não tem acesso, nem conta em redes sociais. E a Persona Danielo (vide tabela 14) aplicou a nota positiva máxima em todas as situações de interação. Esses fatores foram decisivos para que esses perfis permanecessem isolados, formando um grupo cada um dos elementos.

Cada perfil dentro dos grupos mantém uma consistência demográfica e também sobre a percepção em relação aos comportamentos e ações do robô. As percepções de cada perfil, estão sintetizadas e são apresentadas em grupos de informações similares. Essas informações auxiliaram na descrição de cada Persona. A tabela 17 apresenta um compilado das informações referentes a expectativa de ter um robô em casa, na percepção de cada usuário.

Tabela 17 - Expectativa do robô em casa dos perfis por Persona.

\begin{tabular}{|c|c|c|}
\hline \multicolumn{3}{|c|}{ Expectativa do robô em casa? } \\
\hline Persona & Observação & Quantidade \\
\hline \multirow{7}{*}{ Joaquim } & Limpar a casa & 7 \\
\hline & Buscar objetos & 1 \\
\hline & Cuidar da segurança & 1 \\
\hline & Obediência & 4 \\
\hline & Afetividade & 4 \\
\hline & Naturalidade & 3 \\
\hline & Respeito & 3 \\
\hline \multirow{3}{*}{ Maria Eduarda } & Realizar tarefas domésticas & 5 \\
\hline & Dirigir o carro & 1 \\
\hline & Amigável & 1 \\
\hline \multirow{3}{*}{ Alfredo } & Realizar tarefas domésticas & 5 \\
\hline & Comandos de voz & 2 \\
\hline & Obediência & 2 \\
\hline Danielo & Realizar tarefas domésticas & 1 \\
\hline Manuel & Atender necessidades & 1 \\
\hline
\end{tabular}

Fonte: $\mathrm{O}$ autor.

A pergunta da expectativa do robô em casa foi realizada antes da interação com o robô. Com base nas respostas pode-se perceber que as pessoas, no geral, enxergam os robôs como ferramentas. Essa percepção muda após a interação e a demonstração das habilidades dos robôs. Em alguns casos, a mudança de opinião é nítida, onde comentários como "ele faz tudo isso sozinho" são mencionados durante o teste, ou quando o usuário diz que imagina robôs apenas 
na linha de produção de fábricas e montadores, nunca haviam acreditado na hipótese de existir um robô capaz de exercer atividades domésticas. Outra questão discutida antes da interação com o robô é a expectativa sobre o papel dele, em relação ao ambiente de trabalho. As respostas compiladas são apresentadas na tabela 18.

Tabela 18 - Expectativa do robô no ambiente de trabalho dos perfis por Persona.

\begin{tabular}{|c|c|c|}
\hline \multicolumn{3}{|c|}{ Expectativa do robô no ambiente de trabalho? } \\
\hline Persona & Observação & Quantidade \\
\hline \multirow{10}{*}{ Joaquim } & Obediência & 4 \\
\hline & Realizar tarefas & 7 \\
\hline & Indiferente sobre o robô no trabalho & 1 \\
\hline & Eficiência nas atividades & 2 \\
\hline & Comunicação & 1 \\
\hline & Antecipar tarefas & 1 \\
\hline & Gerenciador de TODO List & 1 \\
\hline & Otimizar processos & 1 \\
\hline & Seja sociável & 1 \\
\hline & Agir com naturalidade & 2 \\
\hline \multirow{3}{*}{ Maria Eduarda } & Realizar tarefas & 4 \\
\hline & Eficácia & 1 \\
\hline & Amigável & 1 \\
\hline \multirow{3}{*}{ Alfredo } & Realizar tarefas & 6 \\
\hline & Rápido & 1 \\
\hline & Obediência & 1 \\
\hline Danielo & Executar tarefas repetitivas & 1 \\
\hline Manuel & Atender necessidades & 1 \\
\hline
\end{tabular}

Fonte: $\mathrm{O}$ autor.

Apesar da expectativa no trabalho ser a realização de tarefas, em linhas gerais, alguns outros pontos foram levantados. Comunicação, naturalidade, ser amigável e sociável, além de outros adjetivos voltados para convívio social em ambientes corporativos. Essa percepção pode mostrar tendências para aceitar trabalho em equipe com robôs autônomos de maneira natural. E um ponto que pode auxiliar nessa aceitação é a mudança na gestão de pessoas, que presa por fatores sociais e um ambiente amistoso no local de trabalho.

As tabelas a seguir são de informações que foram coletadas após o experimento de interação social com o robô. A tabela 19 apresenta as percepções sobre o robô, que os participantes mencionaram como positivo e negativo para o gosto de cada um dos participantes.

Através da tabela 19 é possível observar quais pontos do robô, e até como as variáveis de percepção do usuário que foram criadas com base nas heurísticas de interação (vide seção 5.10.1), se relacionam com cada perfil. A visibilidade do estado do robô é um dos pontos mais observados entre os usuários. A relação de feedback do robô, algumas das Personas apontaram como positivo e outras como negativo, pois não foi realizado de maneira adequada. Outro ponto levantado, é a questão do barulho feito pela base do robô, onde 4 das 5 Personas 
Tabela 19 - O que os perfis mais gostaram e menos gostaram separados por Persona.

\begin{tabular}{|c|c|c|c|c|}
\hline \multirow{2}{*}{ Persona } & \multicolumn{2}{|c|}{ (+) Gostou } & \multicolumn{2}{|c|}{ (-) Gostou } \\
\hline & Observação & Quantidade & Observação & Quantidade \\
\hline \multirow{8}{*}{ Joaquim } & Navegação & 4 & Desajeitado & 7 \\
\hline & Face & 12 & $\begin{array}{c}\text { Tempo de localização } \\
\text { no ambiente }\end{array}$ & 2 \\
\hline & Voz & 6 & Barulho das rodas & 4 \\
\hline & Manipulador & 1 & Feedback baixo & 1 \\
\hline & & & Manipulador & 1 \\
\hline & & & Rodas & 1 \\
\hline & & & Fala autoritária & 1 \\
\hline & & & Tempo de resposta & 1 \\
\hline \multirow{4}{*}{ Maria Eduarda } & Navegação & 4 & Estrutura & 2 \\
\hline & Interação & 1 & Manipulador & 2 \\
\hline & Face & 3 & Barulho & 1 \\
\hline & & & Tempo de Resposta & 1 \\
\hline \multirow{6}{*}{ Alfredo } & Face & 2 & Tempo de Resposta & 2 \\
\hline & Voz & 2 & Desajeitada & 1 \\
\hline & Navegação & 1 & Manipulador & 3 \\
\hline & Feedback & 1 & Barulho & 1 \\
\hline & Toque & 1 & Perda da localização & 1 \\
\hline & Interação & 2 & & \\
\hline Danielo & Interação & 1 & Barulho & 1 \\
\hline Manuel & Face e voz & 1 & Manipulador & 1 \\
\hline
\end{tabular}

Fonte: $\mathrm{O}$ autor.

observaram isso como um problema. Além dos pontos positivos e negativos do robô durante a interação, as informações sobre quais pontos geraram desconforto ou medo são importantes. As informações sobre desconforto são apresentadas na tabela 20.

Tabela 20 - Desconforto dos perfis na interação, separados por Persona.

\begin{tabular}{c|c|c}
\hline Persona & Observação & Quantidade \\
\hline \multirow{2}{*}{ Joaquim } & Quase batida no ambiente & 1 \\
\cline { 2 - 3 } & Primeira aproximação & 4 \\
\cline { 2 - 3 } & Balanço da estrutura & 1 \\
\hline \multirow{2}{*}{ Maria Eduarda } & Manipulador & 1 \\
\cline { 2 - 3 } & Aproximação & 1 \\
\hline \multirow{2}{*}{ Alfredo } & Falta de feedback & 2 \\
\cline { 2 - 3 } & Toque & 1 \\
\cline { 2 - 3 } & Aproximação & 2 \\
\hline Danielo & - & 1 \\
\hline Manuel & Manipulador & \\
\hline
\end{tabular}

Fonte: $\mathrm{O}$ autor. 
Na tabela 20 pode-se evidenciar que a aproximação do robô, principalmente ao entrar no espaço pessoal e íntimo da pessoa, gera um nível de desconforto significante. Quando ocorre o toque no participante esse desconforto pode levar a um certo nível de medo para alguns participantes na interação. O controle da aproximação e da invasão das zonas sociais definidas através da teoria de proximidade é importante para melhorar a experiência do usuário e conseguir manter uma interação de longo prazo em outros cenários. As questões relacionadas a proximidade do robô, não condizem apenas com a ação de aproximação. A proximidade é um fator importante que pode influenciar em gestos, expressões faciais e até mesmo volume da voz emitida pelo robô.

Outro resultado apontado pelos questionários aplicados durante o experimento, tem relação com as questões culturais dos participantes. Uma das perguntas apresentadas no questionário de pré teste (vide tabela 6), era a declaração de qual cultura o usuário mais se identifica. Um terço dos participantes declarou que se identifica com a cultura de um país diferente do seu de origem.

Esse indicativo apresentou um alerta para uma hipóteses, onde é questionado que a cultura sobrepõe a experiência do usuário na interação social. Contudo, quando as Personas foram criadas, a cultura obtida através da medida de tendência central foi a do país de origem dos participantes. É possível assim, identificar que por mais que exista a declaração de uma cultura diferente por parte do usuário, a cultura de origem tem maior influência sobre suas ações. A experiência do usuário está ligada aos fatores culturais, podendo ter diferenças entre os costumes de cada cultura perante cada comportamento do usuário. Esse resultado ajuda a identificar algumas das observações feitas por trabalhos s literatura, onde a cultura é um fator discriminante para interação.

Durante os testes piloto, a base do robô que era composta pelo PeopleBot quebrou o encoder da roda, o que inviabilizou o controle de velocidade dele. Se o projeto de construção não estivesse utilizando uma base de arquitetura de software em camadas, através do ROS, a troca por uma nova base poderia ter sido traumática. Porém, com o uso adequado da arquitetura e o software desenvolvido utilizando padrões de projeto que preveem a adaptação de outros componentes com a mesma função, a troca foi realizada praticamente como um componente plug'n play. Removeu-se a original do robô e adaptou-se a base do youBot da Kuka como uma substituta. Pequenos ajustes foram necessários, como a posição dos sensores utilizados na base como o laser. A criação do projeto também possibilitou que novos componentes possam ser inseridos na proposta feita por essa tese. Por exemplo, os componentes para a parte de tomada de decisão do robô, no estudo de caso foi uma técnica para a classificação do usuário durante a aproximação. Outros componentes que podem ser inseridos são os de identificação de medo, conforto e desconforto de maneira automática, possibilitando assim a tomada de decisão de maneira automática sem esperar a declaração do usuário através de voz, questionário ou qualquer outro dispositivo. Sem a especificação do projeto de maneira sistêmica a expansão através de componentes não seria possível. 
Após os passos aplicados durante a etapa de concepção e criação, o classificador Bayesiano de Personas necessita de validação. Na tabela 21 é apresentado informações sobre 16 perfis dos usuários que realizaram o teste para validação do classificador Bayesiano, proposto como estudo de caso deste método.

Tabela 21 - Perfis dos 16 usuários que realizaram o teste de validação.

\begin{tabular}{c|c|c|c|c|c|c|c}
\hline Idade & Altura & Gênero & Feição & Sociável? & $\begin{array}{c}\text { Óculos } \\
\text { de Grau? }\end{array}$ & $\begin{array}{c}\text { Cabelo } \\
\text { Comprido? }\end{array}$ & Etnia \\
\hline 25 & 1.86 & Masculino & Normal & Sim & Sim & Sim & Branca \\
\hline 34 & 1.82 & Masculino & Normal & Sim & Sim & Não & Branca \\
\hline 19 & 1.76 & Masculino & Normal & Sim & Não & Não & Branca \\
\hline 20 & 1.74 & Masculino & Séria/Fechada & Não & Sim & Não & Parda \\
\hline 21 & 1.70 & Masculino & Sorridente & Sim & Não & Não & Branca \\
\hline 26 & 1.68 & Masculino & Normal & Sim & Sim & Não & Parda \\
\hline 27 & 1.81 & Masculino & Séria/Fechada & Sim & Sim & Não & Branca \\
\hline 33 & 1.62 & Feminino & Normal & Sim & Sim & Sim & Branca \\
\hline 37 & 1.79 & Masculino & Normal & Sim & Sim & Não & Branca \\
\hline 37 & 1.79 & Masculino & Normal & Sim & Não & Não & Branca \\
\hline 20 & 1.56 & Masculino & Normal & Sim & Não & Não & Amarela \\
\hline 20 & 1.70 & Masculino & Normal & Não & Sim & Não & Branca \\
\hline 20 & 1.90 & Masculino & Normal & Não & Sim & Não & Parda \\
\hline 20 & 1.73 & Masculino & Normal & Sim & Sim & Não & Branca \\
\hline 29 & 1.59 & Feminino & Normal & Sim & Não & Sim & Branca \\
\hline 61 & 1.60 & Feminino & Sorridente & Sim & Sim & Sim & Branca \\
\hline
\end{tabular}

Fonte: $\mathrm{O}$ autor.

A tabela 21 apresenta as informações declaradas sobre todos os participantes do teste de para criação do classificador. Pode-se identificar os limites das variáveis dos participantes como, a idade mínima apresentada é de 19 anos e a máxima de 61 anos, com uma média de 28 anos e um desvio padrão de 11 anos. A relação entre altura das pessoas, a menor estatura foi de 1,59 m contra 1,90 m da maior. Na altura, a média foi de 1,73 m, mantendo um desvio padrão de $0,11 \mathrm{~m}$. No total foram 13 homens e 3 mulheres na amostra para o teste oficial, distribuídos entre alunos da instituição de ensino e visitantes, todos com o mínimo ou nenhum contato prévio com robôs.

Durante os testes, os participantes elogiaram o comportamento do robô durante toda a tarefa. As variáveis de observação criadas a partir das heurísticas de avaliação de usabilidade, foram questionadas por grande parte dos participantes, no sentido do comportamento do robô. As principais variáveis questionadas foram a visibilidade do estado do robô e a naturalidade dos gestos que o robô executou com o manipulador. Foram variáveis impactantes para determinar em qual Persona cada usuário se enquadra.

O ponto positivo dentre todos os comportamentos e ações do robô foram as expressões faciais. Alguns participantes ficaram com medo do robô quando se aproximou com uma expressão brava. Ao apresentar uma expressão triste, os participantes sentiam dó pelo robô não 
ter conseguido encontrar a sua garrafa. No geral, o comportamento dos participantes era como um novo membro da casa. Apenas um participante associou a um fato negativo a convivência do robô. Seu comentário foi "Apesar de saber que foi devidamente programado, não me sentiria confortável em dividir o ambiente com um ser de polímero e metal com inteligência semelhante a minha". Com base nesse comentário, pode-se dizer que o participante tem medo do robô começar a aprender, e tornar-se mais que uma simples ferramenta, podendo apresentar algum risco físico ao conviver dentro de casa.

Pontos de atenção levantados pelos participantes sobre a presença do robô em casa é a preocupação com o design e o volume que o robô ocupará. São pontos importantes para o desenvolvimento do projeto e aceitação do robô dentro das casas. Outra questão que desagradou alguns dos participantes, foi o excesso de barulho na locomoção do robô pelo ambiente. $\mathrm{O}$ tipo de roda utilizado na base do robô, fez com que o barulho fosse mais alto que o convencional, e acabou por incomodar os participantes.

A fala do robô também foi prejudicada pelo tipo de caixa de som que foi utilizado. $\mathrm{O}$ som saiu abafado e dificultou a compreensão do que o robô estava dizendo, principalmente quando o ambiente estava com um número maior de pessoas. A questão da caixa de som, identificou-se em um momento posterior aos testes, que o problema era falta de bateria nos alto faltantes. Elas foram substituídas em alguns momentos do teste pelo som do próprio computador, responsável por executar todas as funções de controle do robô. Em questão sobre o papel do robô em uma residência, é unânime a opinião de que ele deva fazer as tarefas domésticas simples, porém que ocupam muito tempo das pessoas no dia-a-dia.

Para cada perfil selecionado a realizar o teste de validação, foi feito uma classificação manual com base nas respostas para comparação com o classificador Bayesiano executado nos testes. Na classificação manual encontrou-se 7 perfis para a Persona Joaquim, 4 para a Maria Eduarda, 2 para Alfredo e Danielo, cada, e 1 para a Persona Manuel. A classificação manual é feita como uma ferramenta de comparação para o algoritmo de classificação. Em linhas gerais, essa classificação é feita pelo próprio especialista ao entrevistar o indivíduo.

O trabalho de classificação automático foi realizado pelo software SamIam, onde foi possível construir de maneira visual a rede Bayesiana e determinar os valores das probabilidades condicionais, com base na frequência de eventos observados nos testes piloto. Na execução da rede Bayesiana, eram atribuídos os valores dos nós de efeito, composto pelas variáveis comportamentais de conforto, desconforto e medo. Também as variáveis de ações do robô e cenário de uso, como a posição do usuário na cena, além das variáveis criadas com base nas heurísticas de avaliação de usabilidade. Todo esse conjunto de variáveis fazem parte da camada de nós internos da rede Bayesiana.

Os valores são atribuídos de acordo com cada situação executada durante o teste, e a evidência de conforto, desconforto e medo declarada pelo participante ou observada pelo especialista que acompanhava o teste. A partir dos valores atribuídos o classificador retorna os valores dos nós pais, no caso as Personas, dizendo qual a probabilidade de ser cada Persona. 
A maior probabilidade define a Persona que o classificador escolheu. Durante a classificação a rede Bayesiana conseguiu uma taxa de $68,75 \%$ de acerto, comparada a classificação manual realizada previamente.

As Personas Joaquim e Alfredo, foram as que mais existiram trocas durante a classificação. O motivo dessa troca de perfis na classificação ocorreu, pois os dois perfis são bem parecidos. Ambas Personas possuem o comportamento muito similar, são pequenos detalhes sobre o conforto que fizeram a classificação ser diferente da esperada.

Um outro fator que gerou essa diferença entre os classificadores manual e Bayesiano foram as bases de classificação. O manual tem como base os questionários pré interação, que são as informações que foram mais relevantes ao algoritmo de agrupamento para composição das Personas. Já o classificador Bayesiano tem como base a interação entre o robô e o ser humano. Dessa maneira, podem ocorrer situações de comportamentos da pessoa que não foram mapeadas e impactem no resultado final da classificação. Por exemplo, durante o questionário e entrevista pré teste, o participante informa que está confortável com o teste e não tem problema nenhum ao interagir com o robô. E quando inicia o teste de interação o robô apresenta um comportamento que gera uma experiência ao participante diferente da mapeada anteriormente. Essa situação faz com que a classificação do perfil seja feita diferente da manual.

Essa classificação pode ser correta em um contexto de uso diferente, ou até mesmo de acordo com o estado emocional do participante. Porém, essas variações não foram abordadas nos experimentos realizados nessa tese. A taxa de acerto na classificação de cada Persona ficou da seguinte maneira, Joaquim foi classificado com $71 \%$ de acerto, Maria Eduarda $75 \%$, Alfredo com 50\%, Danielo $100 \%$ e Manuel foi a Persona com menos acertos, a taxa foi de $0 \%$. Porém, a Persona Manuel apresentou apenas um perfil que se enquadrasse como ela. Essa taxa pode ser melhorada, com a execução dos testes com mais pessoas e diferentes perfis para ajustar os valores das probabilidades condicionais. Um outro método para que seja feito uma melhor distribuição dos valores de probabilidades entre os nós é o uso de um algoritmo de aprendizagem.

O uso da especificação de projeto para interação humano-robô seguindo os passos apresentados no capítulo 4 foram essenciais em diversos pontos do projeto. O uso das Personas no classificador Bayesiano só foi possível dado a especificação do contexto de uso. Sem a definição do contexto de uso, não seria plausível utilizar a técnica de Personas. Esse classificador pode ter uma variação das tabelas de probabilidades condicionais, em contextos de uso diferentes. Assim, como novas variáveis podem ser essenciais na estrutura da rede Bayesiana, como por exemplo, expressão facial também das pessoas e variáveis que representem melhor a linguagem corporal dos indivíduos. Um estudo mais aprofundado sobre o comportamento do classificador em outros contextos de uso deve ser realizado. Assim, a proposta pode evoluir para diferentes contextos de uso e novos cenários de atuação. Em casos mais extremos, onde são apresentados muitas pessoas com perfis diferentes dos que já foram mapeados, pode ocorrer de novas Personas aparecerem para classificação. Uma possível solução para utilizar o classificador em 
outros contextos de uso, é criar uma tabela de probabilidade condicional da rede Bayesiana para cada contexto novo. Assim, o robô percebendo qual o contexto que ele se encontra, pode automaticamente ajustar os valores da tabela de probabilidade condicional. Para isso, o robô deve ser informado de maneira manual ou automática (através da percepção do ambiente) com é o contexto de interação que ele se encontra.

Durante os testes, quando alguns usuários estavam sentados, o robô não tinha uma leitura clara do laser. Isso impactou na aproximação do robô, fazendo com que ele passasse com as rodas por cima dos pés dos usuários na interação. Esse ponto é importante, para reconfigurar o robô e adaptar seu comportamento ao estar em uma situação de muito ruído. Na próxima iteração do método proposto, deve-se organizar todas as ideias e colocar em prática o que foi abstraído.

Quando é analisado o projeto em relação aos 5 (cinco) fatores que impactam a experiência do usuário, apresentado no capítulo 3, percebe-se que o projeto gerou uma experiência satisfatória aos participantes. Porém, existem diversos aspectos que devem evoluir ao longo de seu contínuo desenvolvimento. O primeiro fator é a utilidade do produto para o usuário. Nos comentários feitos sobre a expectativa do conviver com o robô em casa e no trabalho, é possível notar que a utilidade para o robô móvel é alta e esperada por todos os participantes do teste. Outro fator de qualidade da experiência do usuário é a integridade funcional. Nesse fator o projeto precisa de alguns cuidados, pois existiram em alguns testes a falha de leitura de sensores como laser e odometria, que levaram a falha do sistema. Os casos de falha, foram em muitos casos, incapazes de se auto recuperar. A falta de integridade pode trazer uma aparência de produto inacabado, gerando problemas de adesão ao robô no ambiente social.

Em questão de usabilidade, o robô necessita melhorar alguns aspectos para proporcionar uma fácil interação. Como grande parte de sua comunicação é realizada através de voz, possibilitar outros idiomas além do inglês tornaria o uso melhor para alguns dos participantes do teste. Além disso, um projeto de manipulador que faça movimentos mais próximos do natural ao ser humano. A falta de naturalidade em relação aos gestos realizados pelo manipulador, gerou a falta do fator de persuasividade. Em vários momentos, ao qual o gesto foi utilizado para comunicar algo ao usuário, não foi possível compreender exatamente o que o robô gostaria de fazer. Esse é um ponto que precisa de evolução nos próximos ciclo de iteração para evolução no projeto. A aparência, último fator apresentado por Hartson e Pyla (2012), apresentou pontos positivos e outros negativos, em uma menor proporção. $\mathrm{O}$ tablet com as faces ajudaram a extrair boas reações dos participantes durante a interação. Inclusive as faces com expressões de tristeza e raiva, também causaram reações positivas dos participantes. Em relação a aparência, o ponto negativo do projeto foi o corpo do robô. Alguns participantes disseram que ele parecia estar inacabado, pois a carenagem do robô aparentava que iria desmontar em alguns movimentos. No geral, os cinco fatores de impacto à experiência de usuário, foram atendidos de maneira positiva entre os participantes do teste. 
Durante a construção do classificador, notou-se que algumas das informações observadas pelos participantes, compunham a lista de heurísticas de avaliação de usabilidade. Investigando as observações realizadas pelo usuário, cada perfil se atentou em diferentes aspectos das heurísticas. Alguns ficaram atentos a naturalidade dos movimentos e fala, outros ao retorno sobre o estado interno do robô. A percepção era alinhada as ações que o robô executava durante o cenário de teste. A percepção do usuário junto com as ações do robô auxiliou na classificação dos diferentes perfis de usuários representados pelas Personas. As percepções do usuário podem gerar uma nova categoria de variáveis que poderão distinguir com maior acurácia os diferentes perfis do usuário. Isso pode ocorrer, pois cada pessoa prioriza as informações observadas de maneira diferente.

Ao rever o ciclo proposto na figura 3 foi contemplado de maneira total as fases de concepção, construção e testes. A fase de análise foi realizada com o mínimo de análise estatística entre as informações. As informações extraídas da análise estatística são importantes para um novo ciclo de melhorias que podem gerar uma versão 2.0 do robô, proporcionando mais experiência de usuário positiva na interação. Para melhorar a análise estatística é necessário incluir outros testes como ANOVA, análise fatorial e qualquer outro que seja compatível com o tipo de informação coletada. Outro ponto que ocorreu durante os testes pilotos, foi a necessidade de melhoria de alguns pontos chaves identificados durante a execução dos testes. Essas melhorias ocorreram antes do fechamento do ciclo por completo, pois já se identificou pontos importantes que se fizeram necessários antes de prosseguir com a fase de testes. $\mathrm{O}$ mecanismo de tomada de decisão também deve ser inserido a parte de realimentação das informações da classificação para adaptar o comportamento do robô ao perfil do usuário através da Persona. A construção de uma arquitetura em camadas foi um dos pontos mais importantes nos resultados obtidos, pois durante a construção foi possível encontrar e mudar os pacotes para outros com melhor desempenho. Além de tornar possível uma manutenção da base do robô que quebrou durante os primeiros testes pilotos. Nessa manutenção, foi realizada a troca de bases do robô. No software foi necessário apenas alterar a configuração da posição do sensor laser na base para funcionamento pleno do robô. 


\section{CONCLUSÕES E TRABALHOS FUTUROS}

A pesquisa da literatura na área de concentração de Interação Humano-Robô evidenciou a falta de propostas de sistematização no processo de construção do robô, envolvendo todo do ciclo de composição de hardware e software. Em engenharia de software e usabilidade (principalmente projeto centrado no usuário) existem ferramentas que podem auxiliar na concepção e construção desse tipo de projeto. Assim, essa tese apresenta um método centrado no usuário para construção de robôs de serviços autônomos voltados a interação social. Com a apresentação desse método, torna-se mais organizado a criação, evolução e manutenção de um projeto de interação humano-robô, tendo os interesses do usuário como o foco na interação. Esse tipo de preocupação é essencial a partir do momento que a popularização da robótica torna-se cada vez maior, principalmente a robótica de serviço para ambientes domésticos onde os fins são para ajudar o ser humano.

Quando observa-se a interação, cada pessoa reage de acordo com sua percepção sobre o robô. Dessa maneira, a identificação do perfil do usuário é importante, pois torna possível o direcionamento do sistema robótico fazendo com que a experiência do usuário seja melhor e com mais qualidade. Essa tese apresenta um método centrado no usuário para interação com robôs de serviços autônomos. Um estudo de caso é realizado no cenário doméstico onde o robô simula a convivência com uma pessoa dentro de um apartamento. Nesse cenário é criado um classificador de perfis de usuários utilizando as técnicas de rede Bayesiana e Personas. O uso de Personas é fundamental, pois é uma maneira de manter o foco do projeto no usuário e ao mesmo tempo potencializar alcance dos perfis. Isso ocorre, pois a técnica de Personas consegue abranger um número muito maior de usuários e seu processamento é menor do que o tratamento de pessoa a pessoa.

A percepção do robô no ponto de vista de cada usuário leva ao agrupamento deles, pois existem similaridades entre seus comportamentos. Cada grupo de perfil que formou uma Persona, percebeu as ações do robô e o avaliou de acordo com sua personalidade. A percepção e avaliação das ações e comportamento do robô feita pelos participantes, proporcionou um cruzamento de informações que resultaram em algumas variáveis de observação com base nas heurísticas de avaliação de usabilidade. Essa percepção auxiliou nas informações referentes a sinais de conforto, desconforto e/ou medo declaradas pelo grupo de maneira uniforme, durante a interação. Além disso, variáveis criadas com base nas heurísticas de avaliação de usabilidade em interação humano-robô apresentaram valores significativos para auxiliar na classificação das Personas. Essa característica proporcionou duas situações. A primeira, o usuário conseguir identificar e solicitar que o robô tenha características correspondentes as heurísticas de avaliação do usuário. A percepção do usuário, pode decorrer de uma nova maneira para classificar o perfil do usuário. A segunda é que as variáveis de observação sugeridas na seção 4.1.2 são consideradas como um ponto de partida para projetos de interação humano-robô, porém não 
deve ser descartado nenhum conjunto de variáveis que possam agregar valor ao mecanismo de tomada de decisão, e também as análises para melhorar o sistema para o usuário.

Especificar de maneira sistêmica o projeto de interação humano-robô apresentou resultados importantes para a evolução e manutenção do robô. Substituição de partes do robô de maneira plug'n play e adição de novos componentes de software responsáveis pelo controle e inteligência do robô durante a execução do projeto. O uso dos testes piloto para coleta de informações que posteriormente viram as Personas no projeto é importante para auxiliar na configuração mais fiel ao público alvo do projeto. Essa primeira análise auxilia a eliminar algumas tendências e comportamento do robô, onde podem ser ajustados antes dos testes efetivos e finais do ciclo de iteração proposto na metodologia de criação de projetos espiral.

A cultura pelo participante não sobrepõe a experiência do usuário, mesmo que o usuário afirme pertencer a uma cultura de sua preferência. Existe um enraizamento forte do comportamento do participante com o meio ao qual ele foi criado, que torna forte o seu vínculo com a cultura a qual ele foi criado. O ponto cultural permanece o mesmo já validado através da literatura de interação humano-robô e também interação humano-computador. Para um estudo mais afundo sobre a cultura dos participantes e sua influência sobre as ações do robô, é necessário um projeto utilizando o mesmo robô aplicado em diferentes continentes pelo mundo.

A criação de um mecanismo de tomada de decisão, a partir da classificação da Persona em interação, para que seja adaptado o comportamento do robô é imprescindível para o avanço das interações sociais. Além disso, trabalhos referentes a aparência do robô devem ser considerados para melhorar o processo de interação. Esses são pontos importantes e devem envolver algumas outras áreas como design de projetos para potencializar a aparência do robô em interações que auxiliem a evolução do projeto de interação.

Após os testes, percebeu-se que o laser posicionado para desviar dos objetos mais baixos no cenário e auxiliar no controle da navegação está em uma posição desfavorável. Foi notado esse ponto, quando o usuário teve seu pé atropelado pelas rodas da base do robô. Não houve lesão corporal ao participante, porém notou-se que o sensor deveria ser posicionado mais abaixo na base para evitar ruídos e conseguir enxergar melhor a área dos pés da pessoa. Para que isso seja realizado, é necessário informar no software a posição exata do laser de modo que sejam calculadas as transformadas do laser para o centro do robô e não afete o mapeamento da área de atuação na navegação, além da leitura do laser para uma distância mais próxima da real. Em um projeto com arquitetura diferente da utilizada sobre as diretrizes do ROS (em camadas) essa alteração poderia ser custosa. Porém, na arquitetura proposta basta alterar parâmetros em um arquivo de configuração. Essa é mais uma das vantagens sobre o trabalho com uma especificação de sistema mais formal.

Quanto ao projeto enviado ao comitê de ética, é importante ressaltar que toda a fase de concepção do método proposto possui os insumos necessários para a confecção da documentação. Entretanto, quando existir projetos que envolvam testes com crianças é importante consultar o comitê de ética, pois existe a obrigatoriedade de documentos a mais com um lingua- 
jar infantil e documento de autorização de participação aos pais. Esses documentos não foram contemplados nessa tese, uma vez que não houve a intenção de testes envolvendo crianças.

O pacote do ROS utilizado para os experimentos dessa tese, também está disponível e funcional, através do endereço https://github.com/amasiero/approach_ control. Esse pacote pode ser adaptado a qualquer base robótica, dado sua organização em camadas. Ele é direcionado as bases do PeopleBot e Kuka youBot, porém caso queira alterar para outra base, basta incluir na camada de driver o pacote de comunicação com a base de preferência para o teste final.

A partir desse ponto, trabalhos futuros podem auxiliar a evoluir a metodologia proposta e o classificador Bayesiano, utilizado como estudo de caso. O primeiro ponto é a criação de um algoritmo de aprendizado para as probabilidades da rede Bayesiana, de acordo com as interações ocorridas com o robô. Para cada nó da rede, pode-se criar um algoritmo para que a identificação das ações e reações na interação sejam automáticas, por exemplo, determinar se o usuário está confortável ou está com medo na interação. Novas variáveis podem ser investigadas para entender em mais detalhes a percepção do usuário sobre o sistema. Sejam essas novas variáveis baseadas em heurísticas ou em outras fontes de informação. A evolução nas iterações do método para refinar as etapas propostas e consolidar com mais ênfase as etapas descritas no capítulo 4. Além do estudo com diferentes robôs e comportamentos iguais para identificar o quanto a aparência influencia dado um comportamento desenvolvido com o intuito de ser centrado no usuário. Outro ponto, é a criação de um mecanismo de adaptação para o comportamento do robô de acordo com a Persona classificada e também uma maneira do robô assumir as características de um Persona com base no momento e cenário da interação. 



\section{REFERÊNCIAS}

ADAMIDES, George et al. \{HRI $\}$ usability evaluation of interaction modes for a teleoperated agricultural robotic sprayer. Applied Ergonomics, v. 62, p. 237-246, 2017. Disponível em: <http://www.sciencedirect.com/science/article/pii/S0003687017300674>.

ADUBOR, Obehioye; ST. JOHN, Rhomni; STEINFELD, Aaron. Personal Safety is More Important Than Cost of Damage During Robot Failure. In: PROCEEDINGS of the Companion of the 2017 ACM/IEEE International Conference on Human-Robot Interaction. Vienna, Austria: ACM, 2017. (HRI '17), p. 403-403. Disponível em:

$<$ http://doi.acm.org/10.1145/3029798.3036649>.

ALBERT, William; TULLIS, Thomas. Measuring the user experience: collecting, analyzing, and presenting usability metrics. [S.1.]: Newnes, 2013.

ALBO-CANALS, J. et al. Comparing two LEGO Robotics-based interventions for social skills training with children with ASD. In: RO-MAN, 2013 IEEE. [S.1.: s.n.], ago. 2013. p. 638-643.

ALENLJUNG, Beatrice et al. User Experience in Social Human-Robot Interaction. Int. J. Ambient Comput. Intell., IGI Global, Hershey, PA, USA, v. 8, n. 2, p. 12-31, abr. 2017. Disponível em: <https://doi.org/10.4018/IJACI.2017040102>.

ALLEN, Jesmond J; CHUDLEY, James J. Smashing UX design: Foundations for designing online user experiences. [S.1.]: John Wiley \& Sons, 2012. v. 34.

AMARAL, Vagner do; GIRALDI, Gilson A; THOMAZ, Carlos E. Segmentaçao Espacial Nao Uniforme Aplicada ao Reconhecimento de Gênero e Expressoes Faciais, 2014.

ANDERSON, Stephen P. Seductive Interaction Design: Creating Playful, Fun, and Effective User Experiences, Portable Document. [S.1.]: Pearson Education, 2011.

AQUINO JUNIOR, Plinio Thomaz; FILGUEIRAS, Lucia Vilela Leite. User Modeling with Personas. In: PROCEEDINGS of the 2005 Latin American Conference on Human-computer Interaction. Cuernavaca, Mexico: ACM, 2005. (CLIHC '05), p. 277-282. Disponível em: $<$ http://doi.acm.org/10.1145/1111360.1111388>.

ARGYLE, Michael. Bodily communication. [S.1.]: Routledge, 1988.

ARGYLE, Michael; DEAN, Janet. Eye-contact, distance and affiliation. Sociometry, JSTOR, p. 289-304, 1965.

ASIMOV, Isaac. I, robot. [S.1.]: Spectra, 2004. 
BARBOSA, Simone; SILVA, Bruno. Interação humano-computador. [S.1.]: Elsevier Brasil, 2010.

BAXTER, Kathy; COURAGE, Catherine; CAINE, Kelly. Understanding Your Users, Second Edition: A Practical Guide to User Research Methods. 2. ed. [S.1.]: Morgan Kaufmann, 2015. (Interactive Technologies).

BEEK, Loy van et al. RoboCup@Home 2015: Rule and Regulations. [S.1.: s.n.], 2015. http://www.robocupathome.org/rules/2015_rulebook.pdf.

BENYON, David. Interação humano-computador. [S.1.]: Pearson, 2011.

BORGES, Antonádia. Sobre pessoas e variáveis: etnografia de uma crença política. Mana, SciELO Brasil, v. 11, n. 1, p. 67-93, 2005.

BOS, Danny Oude et al. EEG-based emotion recognition. The Influence of Visual and Auditory Stimuli, v. 56, n. 3, p. 1-17, 2006.

BRIGGS, Priscilla; SCHEUTZ, Matthias; TICKLE-DEGNEN, Linda. Are Robots Ready for Administering Health Status Surveys': First Results from an HRI Study with Subjects with Parkinson's Disease. In: PROCEEDINGS of the Tenth Annual ACM/IEEE International Conference on Human-Robot Interaction. Portland, Oregon, USA: ACM, 2015. (HRI '15), p. 327-334. Disponível em: <http://doi.acm.org/10.1145/2696454.2696476>.

BROADBENT, Elizabeth. Interactions With Robots: The Truths We Reveal About Ourselves. Annual review of psychology, Annual Reviews, v. 68, p. 627-652, 2016.

BROOKS, Andrew G.; ARKIN, Ronald C. Behavioral Overlays for Non-verbal Communication Expression on a Humanoid Robot. Auton. Robots, Kluwer Academic Publishers, Hingham, MA, USA, v. 22, n. 1, p. 55-74, jan. 2007. Disponível em: $<$ http://dx.doi.org/10.1007/s10514-006-9005-8>.

BROOKS, R.A. A robust layered control system for a mobile robot. Robotics and Automation, IEEE Journal of, v. 2, n. 1, p. 14-23, mar. 1986.

BROOKS, Rodney A. Intelligence Without Representation. Artif. Intell., Elsevier Science Publishers Ltd., Essex, UK, v. 47, n. 1-3, p. 139-159, fev. 1991. Disponível em: $<$ http://dx.doi.org/10.1016/0004-3702(91)90053-M>.

BROWN, L.; KERWIN, R.; HOWARD, A.M. Applying Behavioral Strategies for Student Engagement Using a Robotic Educational Agent. In: SYSTEMS, Man, and Cybernetics (SMC), 2013 IEEE International Conference on. [S.1.: s.n.], out. 2013. p. 4360-4365. 
BUCHNER, Roland et al. Robots in Time: How User Experience in Human-Robot Interaction Changes over Time. In: PROCEEDINGS of the 5th International Conference on Social Robotics - Volume 8239. Bristol, UK: Springer-Verlag New York, Inc., 2013. (ICSR 2013), p. 138-147. Disponível em: <http://dx.doi.org/10.1007/978-3-319-02675-6_14>.

BURGOON, Judee K; STERN, Lesa A; DILLMAN, Leesa. Interpersonal adaptation: Dyadic interaction patterns. [S.1.]: Cambridge University Press, 2007.

CHOI, Jung Ju; KIM, Yunkyung; KWAK, S.S. The autonomy levels and the human intervention levels of robots: The impact of robot types in human-robot interaction. In: ROBOT and Human Interactive Communication, 2014 RO-MAN: The 23rd IEEE International Symposium on. [S.1.: s.n.], ago. 2014. p. 1069-1074.

CLARKSON, Edward; ARKIN, Ronald C. Applying Heuristic Evaluation to Human-Robot Interaction Systems. In: FLAIRS Conference. [S.1.: s.n.], 2007. p. 44-49.

DE BEIR, Albert; VANDERBOGHT, Bram. Evolutionary Method for Robot Morphology: Case Study of Social Robot Probo. In: THE Eleventh ACM/IEEE International Conference on Human Robot Interaction. Christchurch, New Zealand: IEEE Press, 2016. (HRI '16), p. 609-610. Disponível em: <http://dl.acm.org/citation.cfm?id=2906831.2907005>.

DOBRA, A. General classification of robots. Size criteria. In: ROBOTICS in Alpe-Adria-Danube Region (RAAD), 2014 23rd International Conference on. [S.l.: s.n.], set. 2014. p. $1-6$.

DRURY, Jill L.; SCHOLTZ, Jean; KIERAS, David. Adapting GOMS to Model Human-robot Interaction. In: PROCEEDINGS of the ACM/IEEE International Conference on Human-robot Interaction. Arlington, Virginia, USA: ACM, 2007. (HRI '07), p. 41-48. Disponível em: <http://doi.acm.org/10.1145/1228716.1228723>.

DUQUE, I. et al. A different approach of using Personas in human-robot interaction: Integrating Personas as computational models to modify robot companions' behaviour. In: 2013 IEEE RO-MAN. [S.1.: s.n.], ago. 2013. p. 424-429.

ELARA, Mohan Rajesh et al. Using heuristic evaluation for human-humanoid robot interaction in the soccer robotics domain. In: IEEE-RAS International Conference on Humanoid Robots (Humanoids 2007), Pittsburgh, USA, Nov. [S.1.: s.n.], 2007.

ERESHA, Ghadeer et al. Investigating the influence of culture on proxemic behaviors for humanoid robots. In: IEEE. RO-MAN, 2013 IEEE. [S.1.: s.n.], 2013. p. 430-435.

FEIL-SEIFER, David; MATARIĆ, Maja. Using Proxemics to Evaluate Human-robot Interaction. In: PROCEEDINGS of the 5th ACM/IEEE International Conference on 
Human-robot Interaction. Osaka, Japan: IEEE Press, 2010. (HRI '10), p. 143-144. Disponível em: <http://dl.acm.org/citation.cfm?id=1734454.1734514>.

GARRETT, Jesse James. Elements of user experience, the: user-centered design for the web and beyond. [S.1.]: Pearson Education, 2010.

GIOVANNANGELI, C.; GAUSSIER, P. Human-Robot Interactions as a Cognitive Catalyst for the Learning of Behavioral Attractors. In: ROBOT and Human interactive Communication, 2007. RO-MAN 2007. The 16th IEEE International Symposium on. [S.l.: s.n.], ago. 2007. p. $1028-1033$.

GONBATA, Marina Yukari; AQUINO JUNIOR, Plinio Thomaz. Cabeça e Manipulador do Robô Judith @ Home: Projeto Mecânico. Simpósio de Iniciação Científica, Didática e de Ações Sociais de Extensão da FEI (SICFEI), 2016.

GOODRICH, Michael A.; SCHULTZ, Alan C. Human-robot Interaction: A Survey. Found. Trends Hum.-Comput. Interact., Now Publishers Inc., Hanover, MA, USA, v. 1, n. 3, p. 203-275, jan. 2007. Disponível em: <http://dx.doi.org/10.1561/1100000005>.

HALL, Edward Twitchell. The Hidden Dimension. [S.1.]: Anchor Books New York, 1969.

HARTSON, Rex; PYLA, Pardha S. The UX Book: Process and guidelines for ensuring a quality user experience. [S.1.]: Elsevier, 2012.

HEENAN, Brandon et al. Designing Social Greetings in Human Robot Interaction. In: PROCEEDINGS of the 2014 Conference on Designing Interactive Systems. Vancouver, BC, Canada: ACM, 2014. (DIS '14), p. 855-864. Disponível em:

$<$ http://doi.acm.org/10.1145/2598510.2598513>.

HEGEL, F.; LOHSE, M.; WREDE, B. Effects of visual appearance on the attribution of applications in social robotics. In: ROBOT and Human Interactive Communication, 2009. RO-MAN 2009. The 18th IEEE International Symposium on. [S.1.: s.n.], set. 2009. p. 64-71.

HEMMERT, Fabian et al. Animate Mobiles: Proxemically Reactive Posture Actuation As a Means of Relational Interaction with Mobile Phones. In: PROCEEDINGS of the 7th International Conference on Tangible, Embedded and Embodied Interaction. Barcelona, Spain: ACM, 2013. (TEI'13), p. 267-270. Disponível em: $<$ http://doi.acm.org/10.1145/2460625.2460669>.

HENKEL, Z. et al. Evaluation of Proxemic Scaling Functions for Social Robotics. Human-Machine Systems, IEEE Transactions on, v. 44, n. 3, p. 374-385, jun. 2014. 
HENKEL, Zachary; MURPHY, Robin R.; BETHEL, Cindy L. Towards a Computational Method of Scaling a Robot's Behavior via Proxemics. In: PROCEEDINGS of the Seventh Annual ACM/IEEE International Conference on Human-Robot Interaction. Boston, Massachusetts, USA: ACM, 2012. (HRI '12), p. 145-146. Disponível em: $<$ http://doi.acm.org/10.1145/2157689.2157727>.

HENKEL, Zachary et al. A Proxemic-based HRI Testbed. In: PROCEEDINGS of the Workshop on Performance Metrics for Intelligent Systems. College Park, Maryland: ACM, 2012. (PerMIS '12), p. 75-81. Disponível em: $<$ http://doi.acm.org/10.1145/2393091.2393108>.

HIATT, Laura M.; HARRISON, Anthony M.; TRAFTON, J. Gregory. Accommodating Human Variability in Human-robot Teams Through Theory of Mind. In: PROCEEDINGS of the Twenty-Second International Joint Conference on Artificial Intelligence - Volume Volume Three. Barcelona, Catalonia, Spain: AAAI Press, 2011. (IJCAI'11), p. 2066-2071. Disponível em: <http://dx.doi.org/10.5591/978-1-57735-516-8/IJCAI11-345>.

JIANG, Bihan et al. A Dynamic Appearance Descriptor Approach to Facial Actions Temporal Modeling. Cybernetics, IEEE Transactions on, v. 44, n. 2, p. 161-174, fev. 2014.

JOKINEN, Kristiina; WILCOCK, Graham. Modelling User Experience in Human-Robot Interactions. In: Multimodal Analyses enabling Artificial Agents in Human-Machine Interaction: Second International Workshop, MA3HMI 2014, Held in Conjunction with INTERSPEECH 2014, Singapore, Singapore, September 14, 2014, Revised Selected Papers. Edição: Ronald Böck. Cham: Springer International Publishing, 2015. p. 45-56. Disponível em: <https://doi.org/10.1007/978-3-319-15557-9_5>.

User experience in human-robot interactions. In: PROCEEDINGS of the fourth workshop on perceptual quality of systems (PQS 2013), FTW-TECHREPORT-128, FTW, Vienna, Austria. [S.1.: s.n.], 2013.

JOOSSE, Michiel; SARDAR, Aziez; EVERS, Vanessa. BEHAVE: A Set of Measures to Assess Users' Attitudinal and Non-verbal Behavioral Responses to a Robot's Social Behaviors. In: Social Robotics: Third International Conference, ICSR 2011, Amsterdam, The Netherlands, November 24-25, 2011. Proceedings. Edição: Bilge Mutlu. Berlin, Heidelberg: Springer Berlin Heidelberg, 2011. p. 84-94. Disponível em: $<$ http://dx.doi.org/10.1007/978-3-642-25504-5_9>.

KENNEDY, J. et al. Heart vs hard drive: Children learn more from a human tutor than a social robot. In: 2016 11th ACM/IEEE International Conference on Human-Robot Interaction (HRI). [S.1.: s.n.], mar. 2016. p. 451-452. 
KITAGAWA, Masahiro et al. Mutual Adaptation Between a Human and a Robot Based on Timing Control of "Sleep-time". In: PROCEEDINGS of the Fourth International Conference on Human Agent Interaction. Biopolis, Singapore: ACM, 2016. (HAI '16), p. 353-354. Disponível em: <http://doi.acm.org/10.1145/2974804.2980502>.

LAMBERT, David. Body Language One Hundred and One. [S.1.]: Skyhorse Publishing Inc., 2008.

LAMPE, Cliff et al. Robots As Cooperative Partners... We Hope... In: PROCEEDINGS of the 19th ACM Conference on Computer Supported Cooperative Work and Social Computing Companion. San Francisco, California, USA: ACM, 2016. (CSCW '16 Companion), p. 188-192. Disponível em: <http://doi.acm.org/10.1145/2818052.2893360>.

LATTIN, J.; CARROL, D.J.D.; GREEN, P.E. Análise de dados multivariados. [S.1.]: São Paulo: Cegrage Learning, 2011.

LEE, You-Yun; HSIEH, Shulan. Classifying different emotional states by means of EEG-based functional connectivity patterns. PloS one, Public Library of Science, v. 9, n. 4, e95415, 2014.

LI, Y. et al. Continuous Role Adaptation for Human-Robot Shared Control. IEEE Transactions on Robotics, v. 31, n. 3, p. 672-681, jun. 2015.

LINDBLOM, Jessica; ANDREASSON, Rebecca. Current Challenges for UX Evaluation of Human-Robot Interaction. In: Advances in Ergonomics of Manufacturing: Managing the Enterprise of the Future: Proceedings of the AHFE 2016 International Conference on

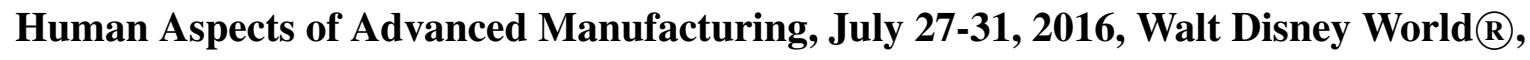
Florida, USA. Edição: Christopher Schlick e Stefan Trzcieliński. Cham: Springer International Publishing, 2016. p. 267-277. Disponível em: <http://dx.doi.org/10.1007/978-3-319-41697-7_24>.

LJUNGBLAD, S. et al. Designing Personal Embodied Agents with Personas. In: ROMAN 2006 - The 15th IEEE International Symposium on Robot and Human Interactive Communication. [S.1.: s.n.], set. 2006. p. 575-580.

LOHSE, Manja; HANHEIDE, Marc et al. Evaluating a social home tour robot applying heuristics, 2008.

LOOI, Qin En; SEE, Swee Lan. Applying Politeness Maxims in Social Robotics Polite Dialogue. In: PROCEEDINGS of the Seventh Annual ACM/IEEE International Conference on Human-Robot Interaction. Boston, Massachusetts, USA: ACM, 2012. (HRI '12), p. 189-190. Disponível em: <http://doi.acm.org/10.1145/2157689.2157749>. 
LÓPEZ, Jose Alexander; CUÉLLAR, Francisco. ROBOTMAN: Security Robot for Human-robot Interaction Inside Malls. In: PROCEEDINGS of the Companion of the 2017 ACM/IEEE International Conference on Human-Robot Interaction. Vienna, Austria: ACM, 2017. (HRI '17), p. 410-410. Disponível em: <http://doi.acm.org/10.1145/3029798.3036653>.

LUNDSTRÖM, J.; MORAIS, W. O. De; COONEY, M. A holistic smart home demonstrator for anomaly detection and response. In: 2015 IEEE International Conference on Pervasive Computing and Communication Workshops (PerCom Workshops). [S.l.: s.n.], mar. 2015. p. 330-335.

MAGRINI, E.; FLACCO, F.; LUCA, A. De. Control of generalized contact motion and force in physical human-robot interaction. In: 2015 IEEE International Conference on Robotics and Automation (ICRA). [S.1.: s.n.], mai. 2015. p. 2298-2304.

MARTELARO, N. et al. Tell me more: Designing HRI to encourage more trust, disclosure, and companionship. In: 2016 11th ACM/IEEE International Conference on Human-Robot Interaction (HRI). [S.1.: s.n.], mar. 2016. p. 577-577.

\section{MASIERO, Andrey Araujo. Algoritmo de Agrupamento por Similaridade aplicado a} Criação de Personas. 2013. Diss. (Mestrado) - São Bernardo do Campo, São Paulo, Brasil. Biblioteca Digital de Teses e Dissertações da FEI. Disponível em:

$<$ http://tede.fei.edu.br/tede/>.

MASIERO, Andrey Araujo; TONIDANDEL, Flavio; AQUINO JUNIOR, Plinio Thomaz. Similar or Not Similar: This Is a Parameter Question. In: ___ Human Interface and the Management of Information. Information and Interaction Design. Berlin, Heidelberg: Springer Berlin Heidelberg, 2013. p. 484-493.

MASIERO, Andrey Araujo et al. Automa-Persona: A Process to Extract Knowledge Automatic for Improving Personas. In: HCI International 2013 - Posters' Extended Abstracts: International Conference, HCI International 2013, Las Vegas, NV, USA, July 21-26, 2013, Proceedings, Part I. Edição: Constantine Stephanidis. Berlin, Heidelberg: Springer Berlin Heidelberg, 2013. p. 61-64. Disponível em: <https://doi.org/10.1007/978-3-642-39473-7_13>.

MASIERO, Andrey Araujo et al. Multidirectional Knowledge Extraction Process for Creating Behavioral Personas. In: PROCEEDINGS of the 10th Brazilian Symposium on Human Factors in Computing Systems and the 5th Latin American Conference on Human-Computer Interaction. Porto de Galinhas, Pernambuco, Brazil: Brazilian Computer Society, 2011. (IHC+CLIHC '11), p. 91-99. Disponível em:

$<$ http://dl.acm.org/citation.cfm?id=2254436.2254454>. 
MCGINN, Conor; SENA, Aran; KELLY, Kevin. Controlling robots in the home: Factors that affect the performance of novice robot operators. Applied Ergonomics, v. 65, p. 23-32, 2017. Disponível em: <http://www.sciencedirect.com/science/article/pii/S0003687017301163>.

MEAD, Ross; ATRASH, Amin; MATARIĆ, Maja J. Automated Analysis of Proxemic Behavior: Leveraging Metrics from the Social Sciences. In: IN Proceedings of the 2011 Robotics: Science and Systems Workshop on Human-Robot Interaction: Perspectives and Contributions. [S.1.: s.n.], 2011a.

. Automated Proxemic Feature Extraction and Behavior Recognition: Applications in Human-Robot Interaction. English. International Journal of Social Robotics, Springer Netherlands, v. 5, n. 3, p. 367-378, 2013. Disponível em: <http://dx.doi.org/10.1007/s12369-013-0189-8>.

. Recognition of Spatial Dynamics for Predicting Social Interaction. In:

PROCEEDINGS of the 6th International Conference on Human-robot Interaction. Lausanne, Switzerland: ACM, 2011b. (HRI '11), p. 201-202. Disponível em: $<$ http://doi.acm.org/10.1145/1957656.1957731>.

. Representations of proxemic behavior for human-machine interaction. In:

CITESEER. NORDICHI 2012 Workshop on Proxemics in Human-Computer Interaction. [S.1.: s.n.], 2012.

MEAD, Ross; MATARIĆ, Maja J. A Probabilistic Framework for Autonomous Proxemic Control in Situated and Mobile Human-robot Interaction. In: PROCEEDINGS of the Seventh Annual ACM/IEEE International Conference on Human-Robot Interaction. Boston, Massachusetts, USA: ACM, 2012. (HRI '12), p. 193-194. Disponível em: <http://doi.acm.org/10.1145/2157689.2157751>.

Autonomous Control of Human-robot Spacing: A Socially Situated Approach. In: PROCEEDINGS of the 1st Symposium on Spatial User Interaction. Los Angeles, California, USA: ACM, 2013. (SUI '13), p. 91-91. Disponível em:

$<$ http://doi.acm.org/10.1145/2491367.2491402>.

. Probabilistic Models of Proxemics for Spatially Situated Communication in HRI. ACM, 2014.

MEAD, Ross; MATARIĆ, Maja J. Autonomous human-robot proxemics: socially aware navigation based on interaction potential. Autonomous Robots, p. 1-13, 2016. Disponível em: <http://dx.doi.org/10.1007/s10514-016-9572-2>. 
MEAD, Ross et al. Building Blocks of Social Intelligence: Enabling Autonomy for Socially Intelligent and Assistive Robots. In: ASSOCIATION for the Advancement of Artificial Intelligence Fall Symposium on Artificial Intelligence and Human-Robot Interaction, ser. AI-HRI, Arlington, Virginia. [S.1.: s.n.], 2014.

MEERBEEK, Bernt; SAERBECK, Martin; BARTNECK, Christoph. Iterative design process for robots with personality. In: PROCEEDINGS of the AISB2009 Symposium on New Frontiers in Human-Robot Interaction Edingburgh pp. [S.1.: s.n.], 2009. v. 94, p. 101.

MINATO, T. et al. CB2: A child robot with biomimetic body for cognitive developmental robotics. In: HUMANOID Robots, 2007 7th IEEE-RAS International Conference on. [S.1.: s.n.], nov. 2007. p. 557-562.

MOGGRIDGE, Bill; ATKINSON, Bill. Designing interactions. [S.1.]: MIT press Cambridge, MA, 2007. v. 17.

MUMM, Jonathan; MUTLU, Bilge. Human-robot Proxemics: Physical and Psychological Distancing in Human-robot Interaction. In: PROCEEDINGS of the 6th International Conference on Human-robot Interaction. Lausanne, Switzerland: ACM, 2011. (HRI '11), p. 331-338. Disponível em: <http://doi.acm.org/10.1145/1957656.1957786>.

NAKATA, Aya et al. Does Being Hugged by a Robot Encourage Prosocial Behavior? In: PROCEEDINGS of the Companion of the 2017 ACM/IEEE International Conference on Human-Robot Interaction. Vienna, Austria: ACM, 2017. (HRI '17), p. 221-222. Disponível em: <http://doi.acm.org/10.1145/3029798.3038397>.

NAVEED, Sidra; RAO, Naveed Iqbal; MERTSCHING, Barbel. Multi Robot User Interface Design Based On HCI Principles. International Journal of Human Computer Interaction (IJHCI), v. 5, n. 5, p. 64, 2014.

NIELSEN, Jakob. Usability engineering. [S.1.]: Elsevier, 1994.

OKITA, Sandra Y.; NG-THOW-HING, Victor; SARVADEVABHATLA, Ravi Kiran. Captain May I?: Proxemics Study Examining Factors That Influence Distance Between Humanoid Robots, Children, and Adults, During Human-robot Interaction. In: PROCEEDINGS of the Seventh Annual ACM/IEEE International Conference on Human-Robot Interaction. Boston, Massachusetts, USA: ACM, 2012. (HRI '12), p. 203-204. Disponível em: <http://doi.acm.org/10.1145/2157689.2157756>.

OSAWA, Hirotaka et al. What is Real Risk and Benefit on Work with Robots?: From the Analysis of a Robot Hotel. In: PROCEEDINGS of the Companion of the 2017 ACM/IEEE 
International Conference on Human-Robot Interaction. Vienna, Austria: ACM, 2017. (HRI '17), p. 241-242. Disponível em: <http://doi.acm.org/10.1145/3029798.3038312>.

PALINKO, Oskar et al. Eye Tracking for Human Robot Interaction. In: PROCEEDINGS of the Ninth Biennial ACM Symposium on Eye Tracking Research \& Applications. Charleston, South Carolina: ACM, 2016. (ETRA '16), p. 327-328. Disponível em:

$<$ http://doi.acm.org/10.1145/2857491.2888590>.

RANI, Pramila; LIU, Changchun; SARKAR, Nilanjan. Affective Feedback in Closed Loop Human-robot Interaction. In: PROCEEDINGS of the 1st ACM SIGCHI/SIGART Conference on Human-robot Interaction. Salt Lake City, Utah, USA: ACM, 2006. (HRI '06), p. 335-336. Disponível em: <http://doi.acm.org/10.1145/1121241.1121303>.

ROSSMANN, J. et al. A Virtual Testbed for Human-Robot Interaction. In: 2013 UKSim 15th International Conference on Computer Modelling and Simulation. [S.l.: s.n.], abr. 2013. p. 277-282.

RUCKERT, J. H. Unity in multiplicity: Searching for complexity of persona in HRI. In: 2011 6th ACM/IEEE International Conference on Human-Robot Interaction (HRI). [S.1.: s.n.], mar. 2011. p. 237-238.

RUCKERT, J. H. et al. Designing for sociality in HRI by means of multiple personas in robots. In: 2013 8th ACM/IEEE International Conference on Human-Robot Interaction (HRI). [S.1.: s.n.], mar. 2013. p. 217-218.

RUEBEN, Matthew et al. Privacy-Sensitive Robotics. In: PROCEEDINGS of the Companion of the 2017 ACM/IEEE International Conference on Human-Robot Interaction. Vienna, Austria: ACM, 2017. (HRI '17), p. 425-426. Disponível em:

<http://doi.acm.org/10.1145/3029798.3029805>.

RUSSELL, Stuart J; NORVIG, Peter. Artificial Intelligence: A Modern Approach. [S.1.]: \{Pearson US Imports \& PHIPEs\}, 2002.

SAARILUOMA, Pertti; JOKINEN, Jussi P. P. Emotional Dimensions of User Experience: A User Psychological Analysis. International Journal of Human-Computer Interaction, v. 30, n. 4, p. 303-320, 2014. eprint: http://dx.doi.org/10.1080/10447318.2013.858460.

Disponível em: <http://dx.doi.org/10.1080/10447318.2013.858460>.

SAMADI, Farshad. HUMAN AGE-GROUP ESTIMATION BASED ON ANFIS USING THE HOG AND LBP FEATURES. Citeseer, 2013.

SHAN, Caifeng. Learning local binary patterns for gender classification on real-world face images. Pattern Recognition Letters, v. 33, n. 4, p. 431-437, 2012. Intelligent Multimedia 
Interactivity. Disponível em:

<http://www.sciencedirect.com/science/article/pii/S0167865511001607>.

SHERIDAN, Thomas B; VERPLANK, William L. Human and computer control of undersea teleoperators. [S.1.], 1978.

SHIRZAD, Navid; VAN DER LOOS, HF Machiel. Evaluating the user experience of exercising reaching motions with a robot that predicts desired movement difficulty. Journal of motor behavior, Taylor \& Francis, v. 48, n. 1, p. 31-46, 2016.

SOMMERVILLE, Ian. Engenharia de Software. [S.1.: s.n.], 2008. v. 9.

SONG, Kai-Tai; CHEN, Yi-Wen. A design for integrated face and facial expression recognition. In: IECON 2011 - 37th Annual Conference of the IEEE Industrial Electronics Society. [S.1.: s.n.], nov. 2011. p. 4306-4311.

SRINIVASAN, V.; HENKEL, Z.; MURPHY, R. Social head gaze and proxemics scaling for an affective robot used in victim management. In: SAFETY, Security, and Rescue Robotics (SSRR), 2012 IEEE International Symposium on. [S.1.: s.n.], nov. 2012. p. 1-2.

STROHKORB, Sarah; SCASSELLATI, Brian. Promoting Collaboration with Social Robots. In: THE Eleventh ACM/IEEE International Conference on Human Robot Interaction. Christchurch, New Zealand: IEEE Press, 2016. (HRI '16), p. 639-640. Disponível em: $<$ http://dl.acm.org/citation.cfm?id=2906831.2907020>.

SUGA, Y. et al. Adaptive Human-Robot Interaction System using Interactive EC. In: 2006 IEEE/RSJ International Conference on Intelligent Robots and Systems. [S.1.: s.n.], out. 2006. p. 3663-3668.

SUTHERLAND, Jeff. Scrum: a arte de fazer o dobro do trabalho na metade do tempo. [S.1.]: Leya, 2016.

TORTA, Elena et al. Design of Robust Robotic Proxemic Behaviour. In: MUTLU, Bilge et al. (Ed.). Social Robotics. [S.1.]: Springer Berlin Heidelberg, 2011. v. 7072. (Lecture Notes in Computer Science). p. 21-30. Disponível em:

<http://dx.doi.org/10.1007/978-3-642-25504-5_3>.

TOUMI, T.; ZIDANI, A. Adaptation of action theory for Human-robot social interaction. In: 2013 International Conference on Individual and Collective Behaviors in Robotics (ICBR). [S.1.: s.n.], dez. 2013. p. 109-114. 
TSUI, Katherine M et al. Developing heuristics for assistive robotics. In: IEEE.

HUMAN-ROBOT Interaction (HRI), 2010 5th ACM/IEEE International Conference on. [S.l.: s.n.], 2010. p. 193-194.

TUREK, Wojciech; CETNAROWICZ, Krzysztof; BORKOWSKI, Adam. On human-centric and robot-centric perspective of a building model. Automation in Construction, v. 81, p. 2-16, 2017. Disponível em:

$<$ http://www.sciencedirect.com/science/article/pii/S0926580517302534>.

VÁZQUEZ, Marynel et al. Spatial and Other Social Engagement Cues in a Child-robot Interaction: Effects of a Sidekick. In: PROCEEDINGS of the 2014 ACM/IEEE International Conference on Human-robot Interaction. Bielefeld, Germany: ACM, 2014. (HRI '14), p. 391-398. Disponível em: <http://doi.acm.org/10.1145/2559636.2559684>.

WALTERS, Michael L et al. An empirical framework for human-robot proxemics. Procs of New Frontiers in Human-Robot Interaction, 2009.

WAZLAWICK, Raul. Engenharia de software: conceitos e práticas. [S.1.]: Elsevier Brasil, 2013. v. 1.

WEISS, Astrid. Validation of an evaluation framework for human-robot interaction. The impact of usability, social acceptance, user experience, and societal impact on collaboration with humanoid robots. 2010. Tese (Doutorado).

WEISS, Astrid; HUBER, Andreas. User Experience of a Smart Factory Robot: Assembly Line Workers Demand Adaptive Robots. 5th International Symposium on New Frontiers in Human-Robot Interaction, 2016.

WOODS, S. et al. Is this robot like me? Links between human and robot personality traits. In: 5TH IEEE-RAS International Conference on Humanoid Robots, 2005. [S.1.: s.n.], dez. 2005. p. $375-380$.

YANG, Zhiguang; AI, Haizhou. Demographic Classification with Local Binary Patterns. In: LEE, Seong-Whan; LI, StanZ. (Ed.). Advances in Biometrics. [S.1.]: Springer Berlin Heidelberg, 2007. v. 4642. (Lecture Notes in Computer Science). p. 464-473. Disponível em: $<\mathrm{http}: / / d x . d o i . o r g / 10.1007 / 978-3-540-74549-5 \_49>$.

YLIOINAS, J.; HADID, A.; PIETIKAINEN, M. Age Classification in Unconstrained Conditions Using LBP Variants. In: PATTERN Recognition (ICPR), 2012 21st International Conference on. [S.1.: s.n.], nov. 2012. p. 1257-1260.

ZLOTOWSKI, Jakub; WEISS, Astrid; TSCHELIGI, Manfred. Interaction Scenarios for HRI in Public Space. In: PROCEEDINGS of the Third International Conference on Social 
Robotics. Amsterdam, The Netherlands: Springer-Verlag, 2011. (ICSR'11), p. 1-10.

Disponível em: <http://dx.doi.org/10.1007/978-3-642-25504-5_1>. 

APÊNDICE A - PROJETO AO COMITÊ DE ÉTICA 
CENTRO UNIVERSITÁRIO FEI - FUNDAÇÃO EDUCACIONAL INACIANA PE. SABOIA DE MEDEIROS

ANDREY ARAUJO MASIERO

ALGORITMO DE APRENDIZADO DO COMPORTAMENTO SOCIAL DO ROBÔ NA APROXIMAÇÃO FÍSICA DO SER HUMANO

São Bernardo do Campo 


\section{RESUMO}

A evolução da tecnologia torna-se cada vez mais evidente com o passar dos anos. As pessoas possuem computadores portáteis menores e com melhor configuração, tablets, aparelhos de telefonia móvel inteligentes interligados com relógios e também robôs que possuem tarefas específicas como aspirar o pó da casa ou monitorar o ambiente a partir de um determinado ponto. Contudo, o robô inserido no ambiente doméstico ou pessoal atual, é apenas mais um dispositivo tecnológico que a pessoa possui. Caso um robô autônomo capaz de realizar diversas tarefas domésticas e de cuidados pessoais médicos seja inserido nesse ambiente e ainda ele realize interações através de voz, gestos e toque com o ser humano, o sentimento a partir desse momento não seria mais de um dispositivo tecnológico no ambiente. Existe uma possibilidade do ser humano ficar de uma certa maneira desconfortável com a presença do robô. Considerando a situação de desconforto do ser humano com o robô, essa tese propõem uma metodologia que mapeia o conjunto de ações que o robô é capaz de executar visando a maximização da probabilidade de uma interação humano-robô com maior qualidade, baseando-se no comportamento e características do indivíduo. A partir do mapeamento de comportamento da pessoa é possível determinar o comportamento que o robô deve ter para proporcionar uma situação confortável para a interação com o ser humano. Como resultado espera-se um framework que possa aprender e analisar o comportamento do ser humano e que também seja capaz de transferir esse conhecimento com o robô inserido no ambiente, aumentando a eficácia da interação entre humanos e robôs.

Palavras-chave: Robótica Social. Proxemics. Aprendizado de Máquina. Interação HumanoRobô. 


\section{SUMÁRIO}

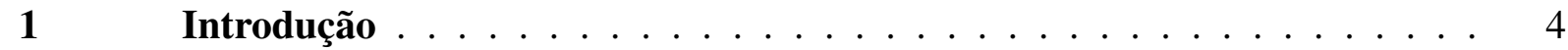

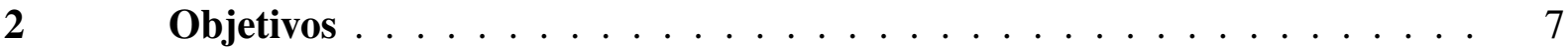

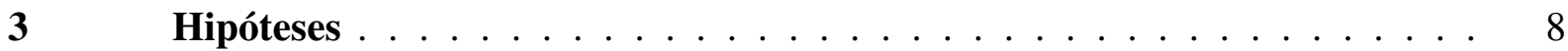

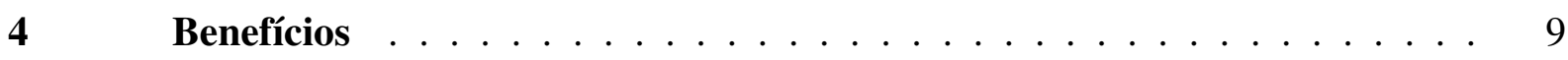

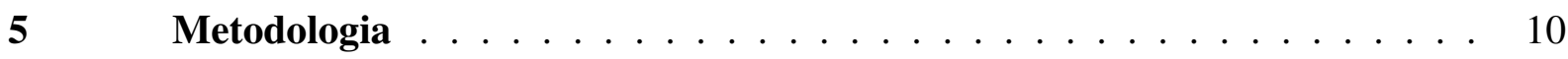

$5.1 \quad$ Perfis dos Sujeitos de Teste . . . . . . . . . . . . . . . 10

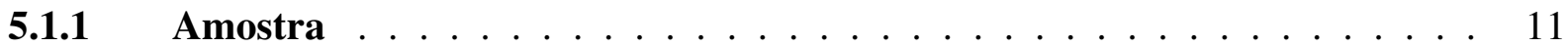

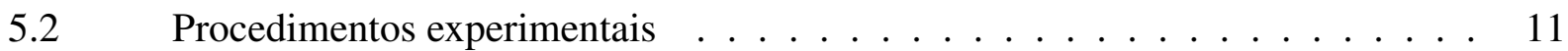

$5.3 \quad$ Dados experimentais coletados . . . . . . . . . . . . . . . . 13

5.4 Processamento e análise de dados coletados . . . . . . . . . . . . . . 13

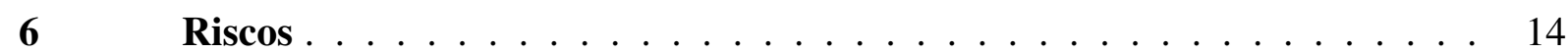

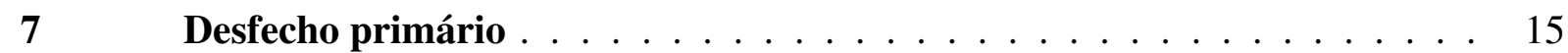

$8 \quad$ Cronograma de Execução $\ldots \ldots \ldots \ldots$

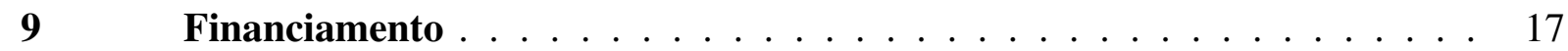

$10 \quad$ Equipe Executora $\ldots \ldots \ldots \ldots \ldots \ldots \ldots$

REFERÊNCIAS . . . . . . . . . . . . . . . . . . . 19 


\section{INTRODUÇÃO}

Durante o passar dos anos foi possível acompanhar a contínua evolução dos sistemas computacionais, como por exemplo os telefones móveis, os computadores pessoais e portáteis, as televisões, e também os robôs pessoais, como o iRobot Roomba ${ }^{1}$ e o $\mathrm{JIBO}^{2}$. Pode-se perceber a evolução ao comparar a quantidade de tarefas que um telefone móvel é capaz de realizar e a diferença entre os tamanhos de seus componentes, os computadores e televisões cada vez com uma espessura menor e a inserção frequente de robôs móveis em ambientes sociais, como as casas e hospitais. Entretanto, os robôs Roomba e JIBO possuem tarefas específicas e o nível de interação com as pessoas não é diferente de alguns dos dispositivos existentes no mercado (HEENAN et al., 2014).

Contudo, existe uma popularização da robótica nos dias atuais principalmente devido ao relativo baixo custo e também devido aos dispositivos tecnológicos cada vez menores. Esse fenômeno faz com que pesquisadores e fabricantes sintam a necessidade de robôs inteligentes que possuam a habilidade de interagir com as pessoas onde este contato não gere desconforto de nenhum indivíduo. Visto que, com a popularização do contato na interação humano-robô aumentará de diversas maneiras, sendo o robô apenas uma ferramenta ou ele sendo um agente no mundo ao qual ele se encontra (LOOI; SEE, 2012). A interação entre robôs e seres humanos é importante não simplesmente pela questão social, mas também porque uma boa interação passa a ser uma questão essencial para a convivência entre todos, ao considerar que robôs já encontram-se em ambientes inteligentes como casas, hospitais e escolas (ALBO-CANALS et al., 2013; BROWN; KERWIN; HOWARD, 2013).

Um ambiente inteligente possui vários meios de interação, além de ser capaz de identificar alguns padrões e ainda ter um certo nível de autonomia em tomadas de decisão. O ambiente realiza as tarefas de interação através de sensores e atuadores espalhados em todos os seus espaços. Alguns sensores que considera-se são câmeras, infravermelhos, térmicos, entre outros. E os atuadores são todos os dispositivos que possam gerar interação, externando algo para o indivíduo, seja através de um movimento, uma imagem ou até mesmo algum sinal sonoro. Alguns exemplos de atuadores são: aparelho de televisão, cafeteira, lâmpadas, tomadas, geladeiras, painéis, aparelhos eletrônicos, entre outros. Dentro do ambiente inteligente também pode existir a presença de um robô móvel, que é um sensor interativo. O robô é capaz de realizar não somente

\footnotetext{
${ }^{1}$ http://www.irobot.com/For-the-Home/Vacuum-Cleaning/Roomba.aspx

${ }^{2}$ https://www.jibo.com/
} 
a leitura de padrões do indivíduo de maneira próxima e seguindo a pessoa a qualquer parte do ambiente, mas o robô também pode servir como um atuador durante a interação (LOOI; SEE, 2012; CHOI; KIM; KWAK, 2014; DOBRA, 2014).

Para aproveitar o robô sem que atrapalhe a rotina existente no ambiente, é necessário que o robô tenha um comportamento social esperado de qualquer agente humano que conviva neste mesmo ambiente. Entre pessoas é esperado um comportamento social onde exista respeito do seu espaço social e até mesmo cuidado durante a execução dos movimentos para que não seja agressivo ou invasivo. Quando existe um cenário de interação humano-robô, onde o ser humano deve realizar tarefas em conjunto com o robô ou até mesmo esperar que o robô realize uma tarefa, o comportamento social por parte do robô tem sido pouco explorado. Sem a preocupação com o comportamento social, o robô acaba gerando um desconforto para as pessoas que estão presentes no mesmo ambiente. O comportamento social pode ir além da execução de movimentos, pois é possível transmitir os sentimentos através de expressões corporais e faciais, além da maneira que se fala com o outro indivíduo. Em seu trabalho Hall (1969) define o termo Proxemics como a ciência que estuda esse comportamento social através de uma métrica de distância entre os indivíduos.

Em um trabalho posterior, Argyle (1988) define quatro níveis de distância social para complementar o trabalho de Hall (1969). Os quatro níveis de distância social são: (I) Íntima; (II) Pessoal; (III) Social; e (IV) Pública, sendo declaradas da mais próxima para a mais distante. O raio que determina cada um desses níveis dependerá da experiência de vida que cada indivíduo possui, podendo ainda ser influenciado pelo o local de origem ou nascimento. Seres humanos conseguem tratar essa questão comportamental de maneira natural e intuitiva. Todavia, as pessoas possuem diferentes perfis e podem reagir ainda de maneira diferente de acordo com a tarefa que estão executando ou o ambiente em que estão inseridos (JUNG, 1991). Dessa forma, há a necessidade de, em muitos casos, adaptar a forma de interação para conseguir ganhar a confiança do indivíduo e conseguir se aproximar dele a uma distância de nível pessoal, pelo menos.

Considerando essas informações, pode-se perceber que o primeiro passo para uma boa interação é estabelecer um nível de confiança com um indivíduo onde a aproximação dele chegue a um nível pessoal. E a partir desse ponto é possível realizar novas tarefas em colaboração ou até em benefício para o próprio indivíduo, como no caso de cuidados pessoais (HALL, 1969; ARGYLE, 1988).

Tendo em vista que para conseguir interagir com o ser humano, o robô deve saber como se aproximar fisicamente da pessoa. Dessa maneira, essa pesquisa tem como objetivo estabe- 
lecer um mecanismo que ao ser inserido no robô, ele seja capaz de perceber algumas sinais corporais da pessoa, como expressão facial e corporal, e mudar seu comportamento para diminuir o medo e ansiedade dela, durante sua aproximação. A partir da aproximação realizada, será possível incluir novos estudos para realizar tarefas em colaboração com o ser humano.

A pesquisa acontecerá nas dependências do Laboratório de Engenharia de Usabilidade da FUNDAÇÃO EDUCACIONAL INACIANA PE. SABOIA DE MEDEIROS em São Bernardo do Campo - SP e, envolverá 100 participantes. Estes participantes serão divididos em 2 grupos: 70 jovens e 30 idosos pertencentes a comunidade acadêmica. Os dois grupos responderão à dois questionários: pré-teste e pós teste. Sendo que o teste é a exposição ao robô propriamente dito. A duração total do experimento será de 40 minutos. 


\section{OBJETIVOS}

Como objetivo principal, este estudo propõem um processo que mapeia o conjunto de ações que o robô é capaz de executar para aumentar a probabilidade de uma aproximação física com o intuito de iniciar uma interação humano-robô que atenda a um determinado padrão social.

Os objetivos secundários almejados nessa pesquisa são: (I) Construção de um framework para aprendizado da aproximação física para interação entre humanos e robôs; (II) Conseguir encapsular o conhecimento sobre o aprendizado de interação para que seja fácil aplicá-lo em diversos robôs. 


\section{HIPÓTESES}

Como hipóteses de comprovação essa pesquisa apresenta:

a) O comportamento do robô tem maior influência na interação social do que sua aparência;

b) É necessário pelo menos uma mídia de saída para que o robô possa interagir dentro das normas sociais;

c) Padrões de comportamento de interação social são definidos com base na cultura, porém a experiência de vida do indivíduo aumenta as possibilidades de interação humanorobô. 


\section{BENEFÍCIOS}

Com o aumento de dispositivos inteligentes em casas, hospitais e ambientes de trabalho, pode haver um certo desconforto por parte do ser humano. Dispositivos focado em internet das coisas tem a atuação transparente para o indivíduo que frequenta àquele ambiente. Contudo, quando falamos de robôs o cenário é diferente, pois um robô atua no ambiente como qualquer outro agente, seja ele outro ser humano ou até mesmo animais de estimação. Os benefícios previstos por essa pesquisa são robôs de serviço e sociais, que apresentem comportamentos mais próximos ao natural para o ser humano. Dessa maneira, será possível que o ser humano não fique com desconforto com a presença do robô em ambientes sociais. Ao final dessa pesquisa, deve-se apresentar um componente de software para aplicar no mecanismo de inteligência, onde o robô será capaz de perceber as reações do usuário, de acordo com seu comportamento e alteralo quando necessário. O foco é apenas na aproximação do robô, visto que esse é o primeiro passo para o início de uma interação social. 


\section{METODOLOGIA}

A pesquisa desenvolvida neste trabalho mantém como base os problemas de interação que são apresentados ao longo da introdução desta tese buscando sempre a qualidade na interação entre o indivíduo e o robô. A fundamentação do trabalho foi realizada em pesquisas de cada uma das áreas abrangentes, Interação Humano-Robô utilizando o conceito de Proxemics e Raciocínio Baseado em Casos, onde identificou-se a possibilidade da criação de um processo automático de aprendizagem e também de aplicação do aprendizado durante toda a fase de interação entre os agentes, humano e robô.

Com o objetivo definido, realizou-se um estudo referente às técnicas que podem ser utilizadas em cada fase da metodologia de Raciocínio Baseado em Casos, para um melhor armazenamento de situações e também a melhor tomada de decisão para cada situação atual. Além disso, também é realizado a definição do conjunto de variáveis que são considerados mais adequados, tanto referente ao indivíduo quanto ao robô, que possam apoiar todo o processo de interação humano-robô.

Definidos os conjuntos de variáveis e também a implementação das técnicas de cada uma das etapas do Raciocínio Baseado em Casos, são realizados alguns testes preliminares de interação do robô para coletar a base de dados inicial e análise prévia dessas informações. $\mathrm{Na}$ sequência dos testes aplicados com indivíduos de diversos perfis comportamentais e demográficos são realizados. O primeiro teste é relacionado a primeira abordagem de interação e o segundo teste está relacionado com alguma tarefa das regras atuais da Robocup@ Home (BEEK et al., 2015).

Realizados os testes, os resultados serão analisados e discutidos realizando a validação do processo de aprendizagem do robô para interação com pessoas.

\subsection{PERFIS DOS SUJEITOS DE TESTE}

Serão selecionados, dentro da comunidade acadêmica, 100 sujeitos de teste não portadores de deficiência física ou motora. Os sujeitos de teste serão brevemente entrevistados sobre o conforto em permanecer com um robô de um metro e meio de altura, dentro de uma sala, junto com o especialista que acompanhará o teste e iniciará o robô no início do teste. Não havendo nenhum empecilho por parte do sujeito de teste, após a leitura do termo de consentimento e 
esclarecido, os experimentos poderão ocorrer logo após a assinatura que estão de acordo em participar do teste.

É importante ressaltar que nenhum sujeito de teste deverá pagar ou será remunerado pela participação na equipe. Qualquer custo, que ele tenha para se deslocar será fornecido pela instituição ou pelo próprio pesquisador.

\subsubsection{Amostra}

Os sujeitos de teste serão divididos da seguinte maneira:

Tabela 1 - Divisão das amostras entre os sujeitos de teste

\begin{tabular}{||l|l||}
\hline \hline Identificação do Grupo & Número de indivíduos \\
\hline Jovens & 70 \\
Idosos & 30 \\
\hline \hline
\end{tabular}

\subsection{PROCEDIMENTOS EXPERIMENTAIS}

O procedimento experimental será realizado em 4 fases, que devem durar no máximo 40 minutos em seu total.

Na primeira fase é introduzida uma breve explicação sobre a execução do experimento. É informado ao sujeito de teste que todo procedimento experimental do teste é filmado e não haverá exposição da imagem comercialmente. $\mathrm{O}$ vídeo será utilizado apenas para fins científicos e com total preservação da identidade do sujeito de teste. É realizado a leitura do termo de consentimento e feita as devidas assinaturas para oficializar o de acordo sobre a participação do experimento. No início do experimento é realizado um questionário pré teste que deve ser preenchido com informações sobre o sujeito de teste, dados etnográficos sem identificação pessoal, e perguntas sobre a expectativa dele para com o comportamento do robô.

A segunda fase é o procedimento experimental com o robô. Nessa fase, o robô é posicionado em frente ao sujeito de teste, com uma distância de aproximadamente 3 (três) metros e meio, que representa o limite entre a zona pública e social do espaço pessoal para interação em sociedade (HALL, 1969; ARGYLE, 1988). O robô irá se aproximar do sujeito de teste até atingir uma distância máxima de 40 (quarenta) centímetros, que representa o limite entre 
a zona pessoal e íntima de uma pessoa. A aproximação do robô poderá ocorrer com algumas configurações, são elas:

a) O robô, sem nenhuma mídia de saída (face, voz, manipulador), deverá se aproximar do sujeito de teste apenas com a característica de sua velocidade de aproximação. Será apenas uma por experimento, sorteada de maneira aleatória. O domínio da velocidade é composto por dois valores: rápido e devagar.

b) O robô apenas com a mídia de saída visual do tipo face, deverá se aproximar do sujeito de teste. As condições de velocidade são as mesmas descritas na primeira configuração de teste. A face apresentada é única durante todo o experimento. Sorteada de maneira aleatória, pode ser classificada como: Feliz, Neutro e Nervoso.

c) O robô apenas com a mídia de saída auditiva do tipo voz, deverá se aproximar do sujeito de teste. As condições de velocidade são as mesmas descritas na primeira configuração de teste. A voz apresentada terá volume único durante todo o experimento. Sorteada de maneira aleatória, pode ser classificada como: Volume alto e volume baixo.

d) O robô apenas com a mídia de saída visual do tipo manipulador, deverá se aproximar do sujeito de teste. As condições de velocidade são as mesmas descritas na primeira configuração de teste. O manipulador apresentará uma amplitude de gestos durante toda aproximação. Sorteada de maneira aleatória, pode ser classificado como: Amplitude alta e amplitude baixa.

e) O robô irá se aproximar do sujeito de teste mesclando as configurações do experimento anteriores.

f) O robô usará informações sobre o sujeito de teste, para inferir a melhor maneira de se aproximar, de acordo com as mídias sociais disponíveis. As informações do sujeito de teste que o robô irá utilizar são: expressão facial e corporal, gênero, se a pessoa se afastou ou não, entre outras.

A qualquer momento, o sujeito de teste poderá desistir do teste. Caso sinta-se ameaçado pelo robô, existe um botão de emergência vermelho que desabilita o robô inteiro. Quando o robô atingir a distância final, será informado pelo especialista que acompanha o teste, que o mesmo terminou.

Seguindo, a terceira fase o sujeito de teste preencherá um questionário pós teste para auxiliar a avaliação do comportamento do robô no seu ponto de vista. Por fim, a quarta fase é 
uma entrevista com o pesquisador. É realizado um bate papo informal para coletar a do sujeito de teste opinião sobre a interação entre ele e o robô.

\subsection{DADOS EXPERIMENTAIS COLETADOS}

Em todos os ensaios, serão coletados dados de imagens capturadas pelas câmeras do robô e dispostas no ambiente. Informações sobre a expressão corporal do sujeito de teste também será capturada a partir de um sensor de movimento. O sensor de movimento é o Microsoft Kinect. Toda a coleta de informações é através de métodos não invasivos ao sujeito de teste e será realizado de maneira transparente a ele.

\subsection{PROCESSAMENTO E ANÁLISE DE DADOS COLETADOS}

As informações serão analisadas a partir dos arquivos de logs. Algoritmos de agrupamento de dados e testes estatísticos serão realizados para tentar identificar alguns padrões entre os usuários e seus comportamentos durante o experimento. Para isso, programas escritos em linguagens JAVA e Python serão utilizados. A biblioteca Matplotlib em Python será utilizada para criar os gráficos das análises.

Ao final serão comparadas as diversas configurações de experimento para tentar identificar uma classificação da melhor para a pior configuração. 


\section{RISCOS}

Os riscos são mínimos não havendo nenhuma evidência específica de que o participante irá sofrer algum dano como consequência imediata ou tardia do estudo. A interação realizada com o robô pode gerar um contato físico, porém o robô possui mecanismos de parada de emergência em si próprio e também de maneira remota. Um especialista estará ao lado do robô para manter o controle de qualquer comportamento inesperado. O robô possui pelo menos 5 (cinco) mecanismos para prevenir um contato físico inesperado com o sujeito de teste. A figura 1 apresenta os mecanismos, sendo 3 (três) sensores e 2 (dois) botões de contato. Além disso, remotamente, um operador poderá interromper as atividades do robô de maneira remota, via software. Os testes serão realizados durante o horário em que equipes médicas disponíveis na universidade, estiverem presentes para atender qualquer emergência. Se mesmo assim o sujeito de teste não se sentir confortável para realizar o teste, a qualquer instante, ele poderá interromper imediatamente todo o procedimento.

Figura 1 - Sensores e botões de emergência disponíveis no robô para evitar qualquer contato físico inesperado.

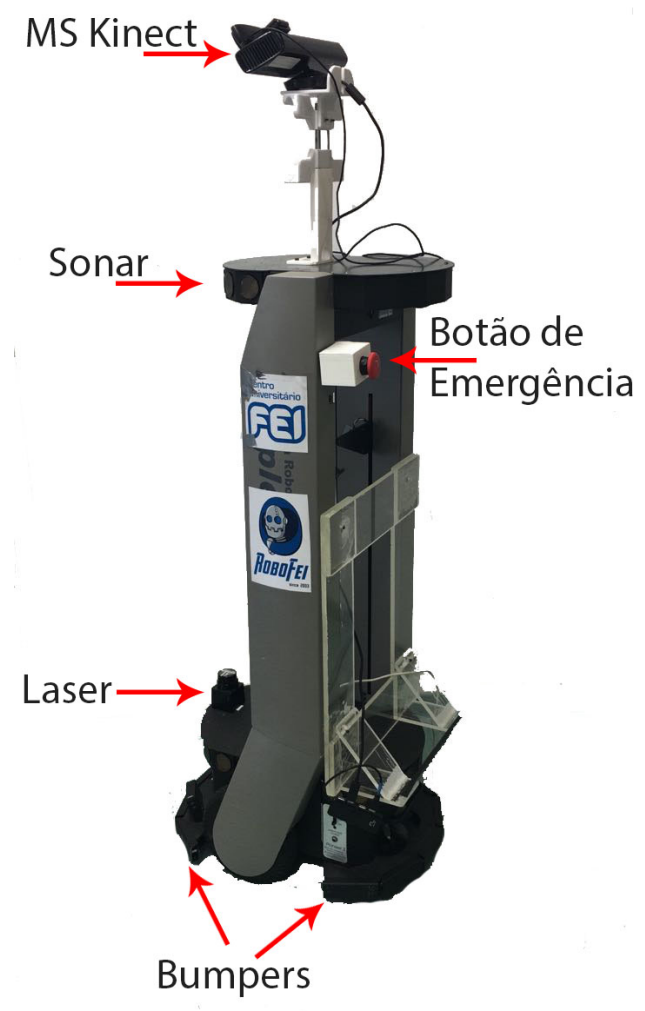




\section{DESFECHO PRIMÁRIO}

Identificar os pontos do comportamento do robô que geraram desconforto ao ser humano. Dessa maneira, será possível mitigar tais problemas em projetos futuros voltados para robótica social e de serviço, onde a interação com o ser humano e o robô é maior. 


\section{CRONOGRAMA DE EXECUÇÃO}

Tabela 2 - Cronograma de trabalho

\begin{tabular}{|l|l|l|}
\hline Identificação da Etapa & Início (dd/mm/aaaa) & Fim (dd/mm/aaaa) \\
\hline Submissão dos projetos & $20 / 06 / 2017$ & $20 / 06 / 2017$ \\
Pesquisa bibliográfica & $21 / 06 / 2017$ & $30 / 06 / 2017$ \\
Seleção dos grupos de Sujeitos de Teste * & $07 / 07 / 2017$ & $14 / 07 / 2017$ \\
Realização de coleta de dados & $15 / 07 / 2017$ & $01 / 08 / 2017$ \\
Avaliação de resultados & $02 / 08 / 2017$ & $31 / 08 / 2017$ \\
Publicação & $01 / 08 / 2017$ & $31 / 10 / 2017$ \\
Relatório & $03 / 08 / 2017$ & $24 / 08 / 2017$ \\
Participação em congressos & $03 / 09 / 2017$ & $20 / 12 / 2017$ \\
\hline
\end{tabular}

Duração: 6 meses.

(*) Essa fase só será iniciada, mediante a aprovação do comitê de ética. 


\section{FINANCIAMENTO}

Este projeto é financiado pela própria instituição. Não há financiamento específico de modo que não estamos apresentando nenhuma planilha de custos. A presente pesquisa é desenvolvida segundo recursos de uso corrente na instituição, sem nenhuma alocação específica. Ou seja, para o desenvolvimento do estudo, hora submetido à apreciação do comitê de ética, não há alocação específica de recursos.

O pesquisador é bolsista de doutorado pelo programa da CAPES/PROSUP, sendo então já remunerado para realizar a pesquisa em tempo integral. O robô e equipamentos utilizados para realização da pesquisa, como computadores, cameras e afins, já são patrimônio da instituição de ensino superior, não havendo custo e o valor deles já esta depreciado uma vez que foram adquiridos no ano de 2005. Os formulários utilizados para pre e pós teste serão digitais, evitando assim o uso de papel e auxiliando na preservação do meio ambiente.

A tabela 3 apresenta o valor de todos equipamentos, patrimoniados, disponibilizados pela instituição para a pesquisa, além do valor dos 48 meses de bolsa do pesquisador Andrey Araujo Masiero, competentes ao seu doutorado.

Tabela 3 - Valores dos equipamentos

\begin{tabular}{||l|l||}
\hline \hline Identificação do Grupo & Valor em R\$ \\
\hline 1x Robô Peoplebot & $92.582,66$ \\
1x Microfone Shotgun Yoga & 180,00 \\
2x Conversor RS232 - USB & 120,00 \\
5x Baterias 12v - 7,2Ah & 350,00 \\
2x Carregadores para as baterias & 220,00 \\
1x Placa conversor de tensão & 30,00 \\
1x Dynamixel RX-64 Robot Actuator & 960,00 \\
2x Dynamixel RX-28 Robot Actuator & $1.440,00$ \\
3x Dynamixel RX-24F Robot Actuator & 420,00 \\
1x Scanning range finder - URG-04LX-UG01 & $3.800,00$ \\
1x Câmera Web cam Full HD - Logitech & 439,00 \\
1x Tablet iPad Apple 64Gb & $6.965,00$ \\
1x Macbook Pro Apple 8Gb & $9.899,10$ \\
Bolsa de estudos referente a 48 meses & $105.600,00$ \\
\hline \hline Total & $223.005,76$ \\
\hline \hline
\end{tabular}




\section{EQUIPE EXECUTORA}

\begin{tabular}{|r||l|}
\hline Nome: & Andrey Araujo Masiero \\
\hline CPF: & $215.870 .658-94$ \\
\hline Lattes: & $<$ http://lattes.cnpq.br/1752106252255038> \\
\hline \hline Nome: & Flavio Tonidandel \\
\hline CPF: & $972.810 .426-04$ \\
\hline Lattes: & $<$ http://lattes.cnpq.br/5331230734386657> \\
\hline \hline Nome: & Plinio Thomaz Aquino Junior \\
\hline CPF: & 162.153.428-66 \\
\hline Lattes: & $<$ http://lattes.cnpq.br/6186413528999908> \\
\hline
\end{tabular}




\section{REFERÊNCIAS}

ALBO-CANALS, J. et al. Comparing two lego robotics-based interventions for social skills training with children with asd. In: RO-MAN, 2013 IEEE. [S.1.: s.n.], 2013. p. 638-643. ISSN 1944-9445.

ARGYLE, M. Bodily communication. [S.1.]: Routledge, 1988.

BEEK, L. van et al. RoboCup@Home 2015: Rule and Regulations. 2015. <http: //www.robocupathome.org/rules/2015_rulebook.pdf>.

BROWN, L.; KERWIN, R.; HOWARD, A. Applying behavioral strategies for student engagement using a robotic educational agent. In: Systems, Man, and Cybernetics (SMC), 2013 IEEE International Conference on. [S.1.: s.n.], 2013. p. 4360-4365.

CHOI, J. J.; KIM, Y.; KWAK, S. The autonomy levels and the human intervention levels of robots: The impact of robot types in human-robot interaction. In: Robot and Human Interactive Communication, 2014 RO-MAN: The 23rd IEEE International Symposium on. [S.l.: s.n.], 2014. p. 1069-1074.

DOBRA, A. General classification of robots. size criteria. In: Robotics in Alpe-Adria-Danube Region (RAAD), 2014 23rd International Conference on. [S.l.: s.n.], 2014. p. 1-6.

HALL, E. T. The Hidden Dimension. [S.1.]: Anchor Books New York, 1969.

HEENAN, B. et al. Designing social greetings in human robot interaction. In: Proceedings of the 2014 Conference on Designing Interactive Systems. New York, NY, USA: ACM, 2014. (DIS '14), p. 855-864. ISBN 978-1-4503-2902-6. Disponível em: <http: //doi.acm.org/10.1145/2598510.2598513>.

JUNG, C. The archetypes and the collective unconscious. Routledge, 1991.

LOOI, Q. E.; SEE, S. L. Applying politeness maxims in social robotics polite dialogue. In: Proceedings of the Seventh Annual ACM/IEEE International Conference on Human-Robot Interaction. New York, NY, USA: ACM, 2012. (HRI '12), p. 189-190. ISBN 978-1-4503-1063-5. Disponível em: <http://doi.acm.org/10.1145/2157689.2157749>. 
APÊNDICE B - TABELAS DE PROBABILIDADES CONDICIONAIS 
Figura 25 - TPC - alfredo

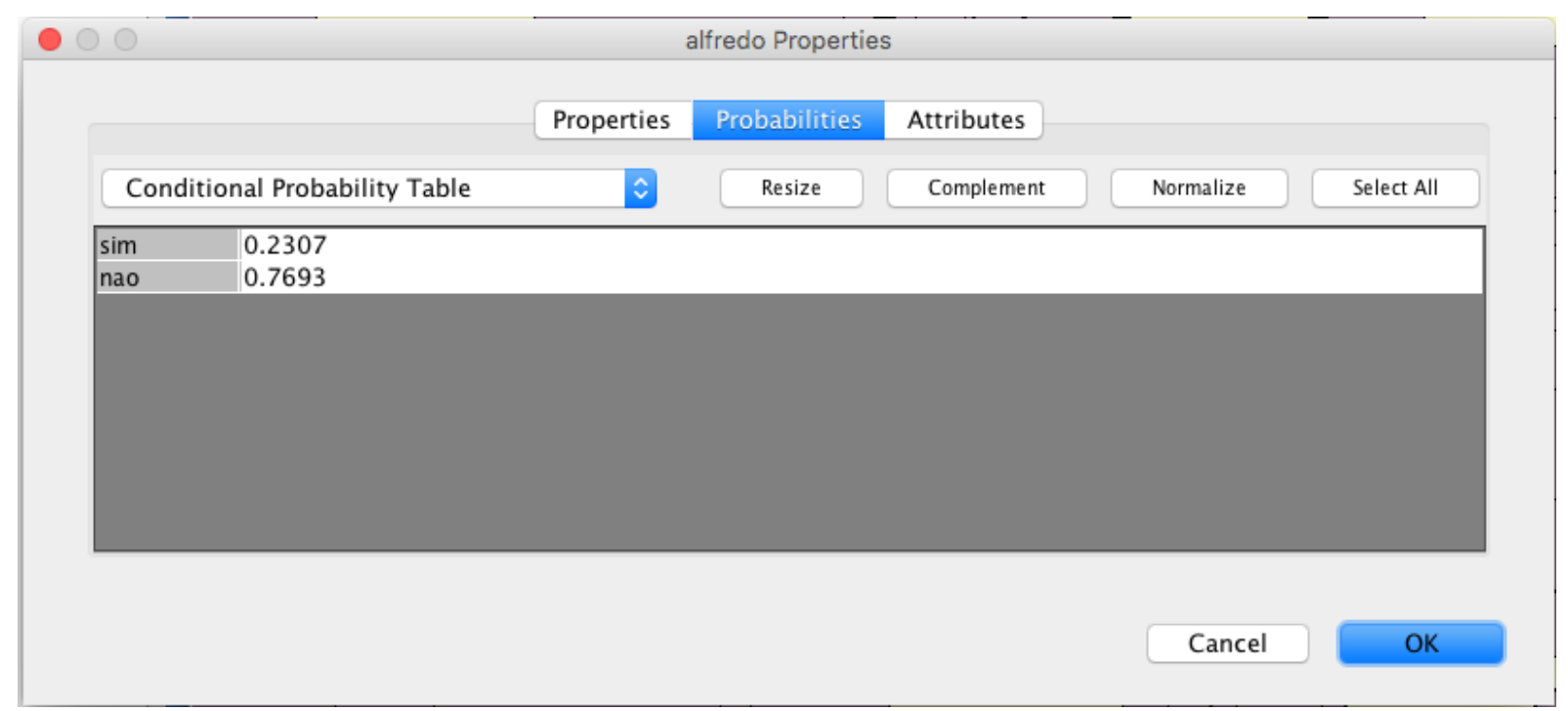

Fonte: Autor.

Figura 26 - TPC - maria_eduarda

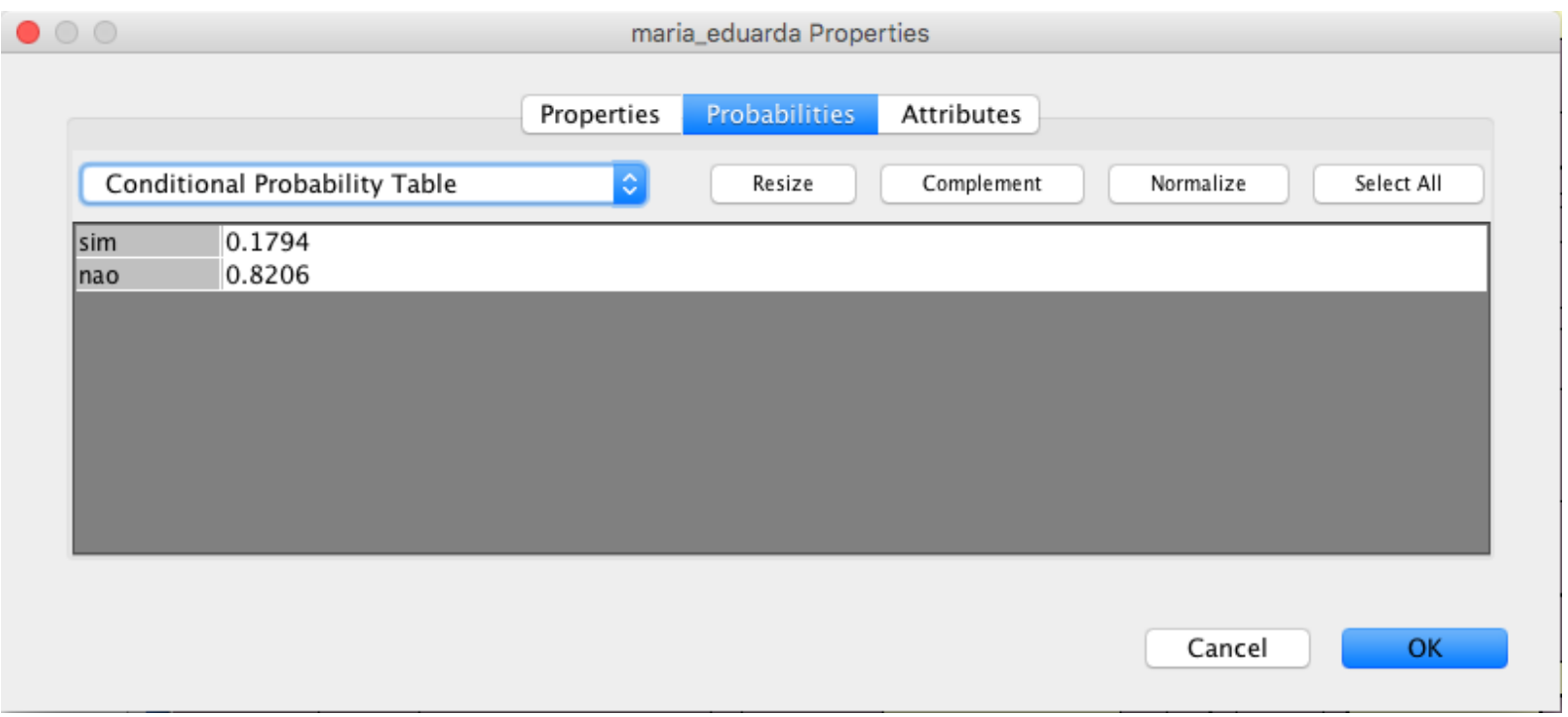

Fonte: Autor. 
Figura 27 - TPC - manuel

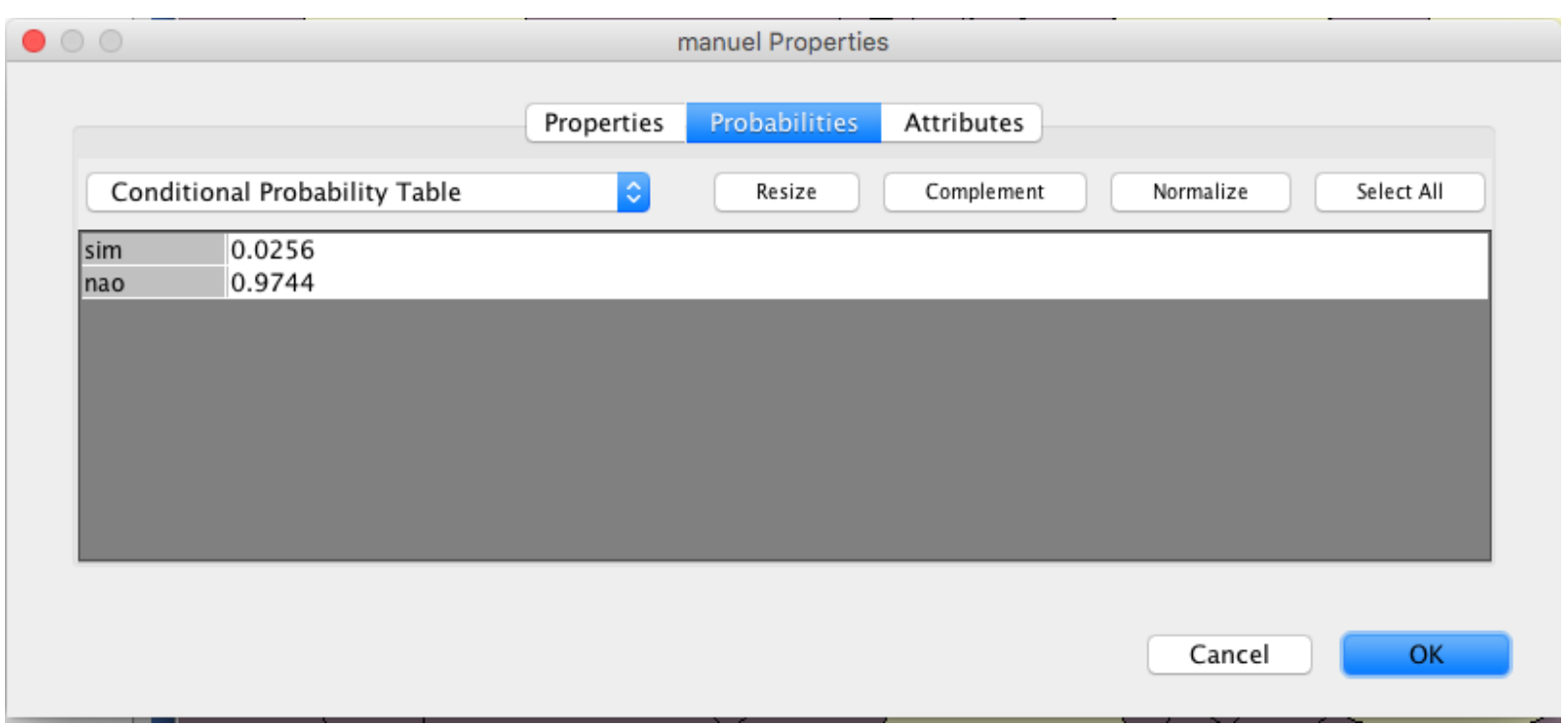

Fonte: Autor.

Figura 28 - TPC - danielo

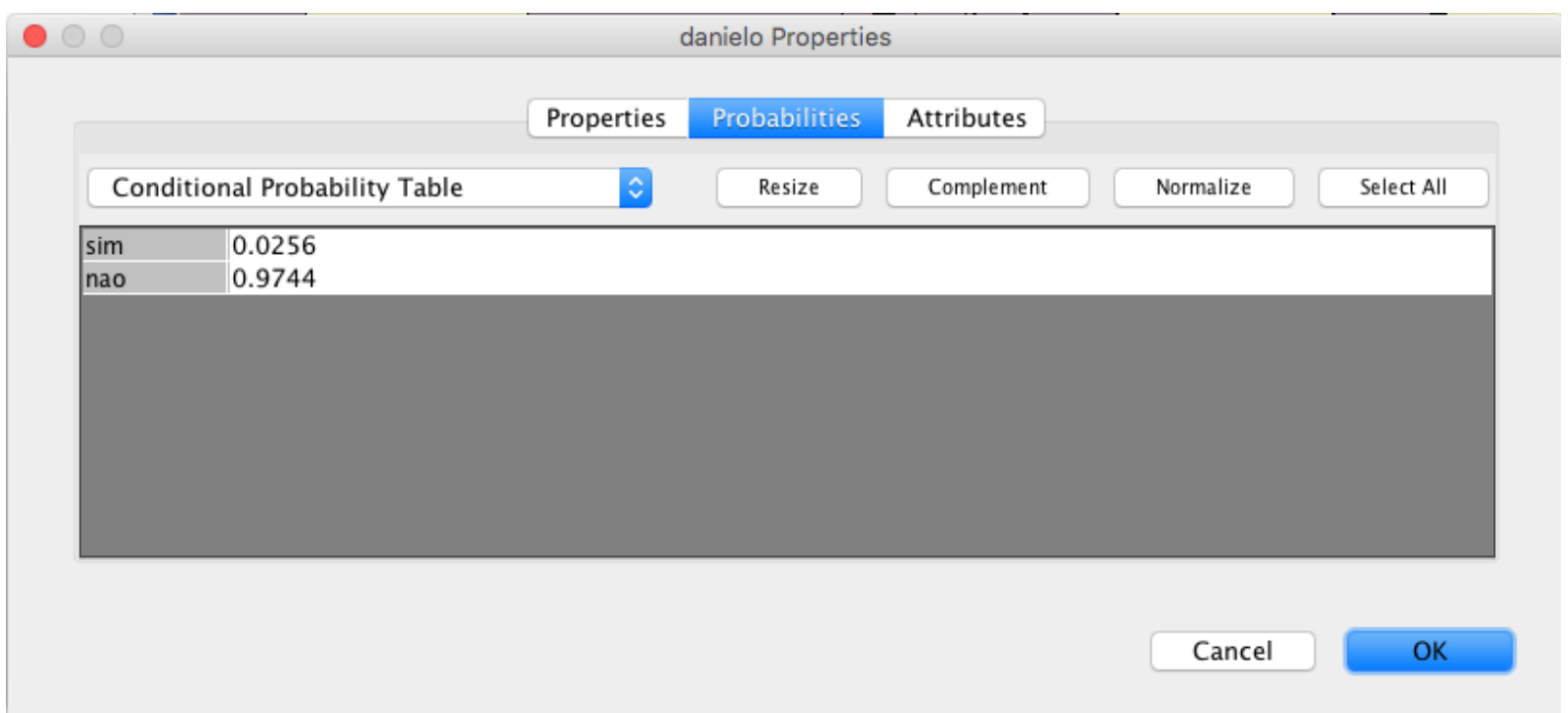

Fonte: Autor. 
Figura 29 - TPC - joaquim

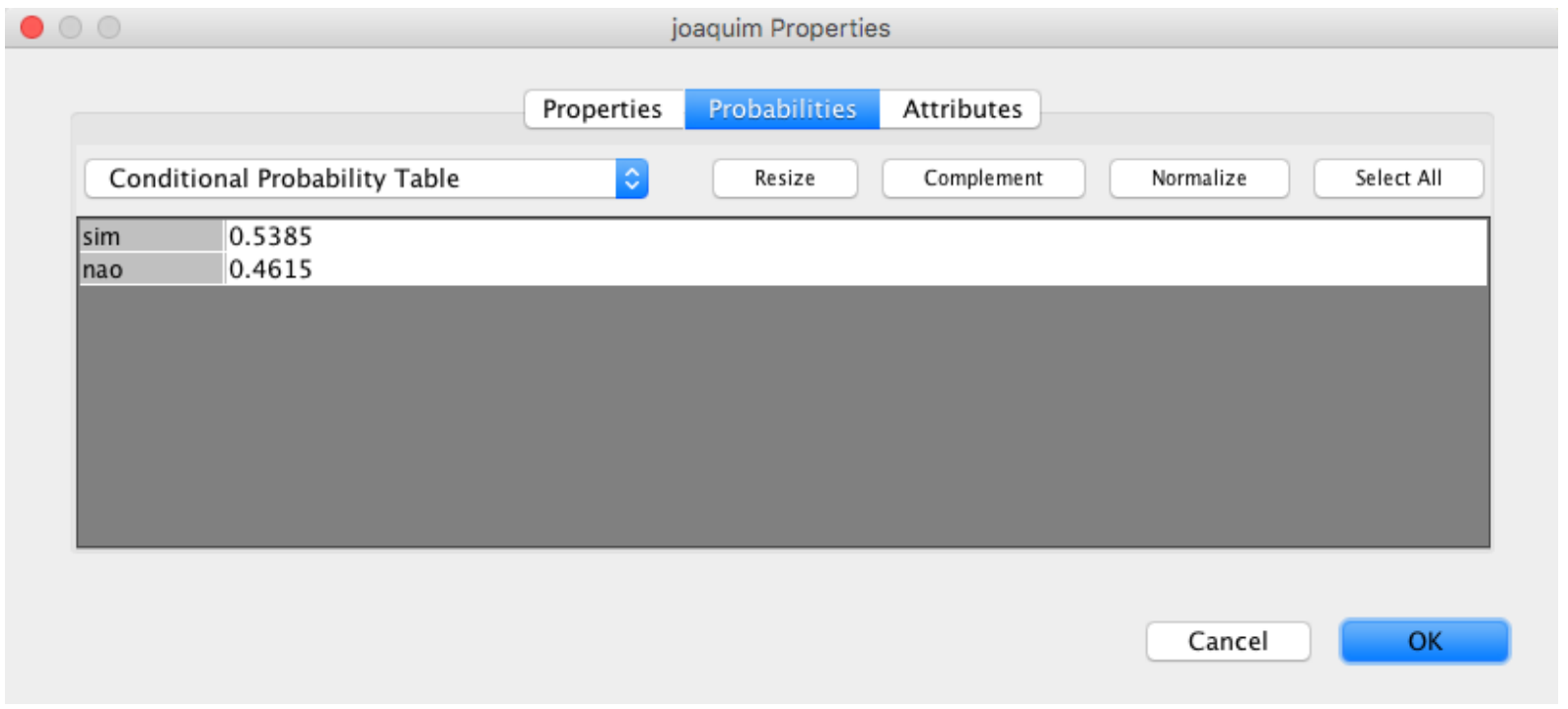

Fonte: Autor.

Figura 30 - TPC - ajuda

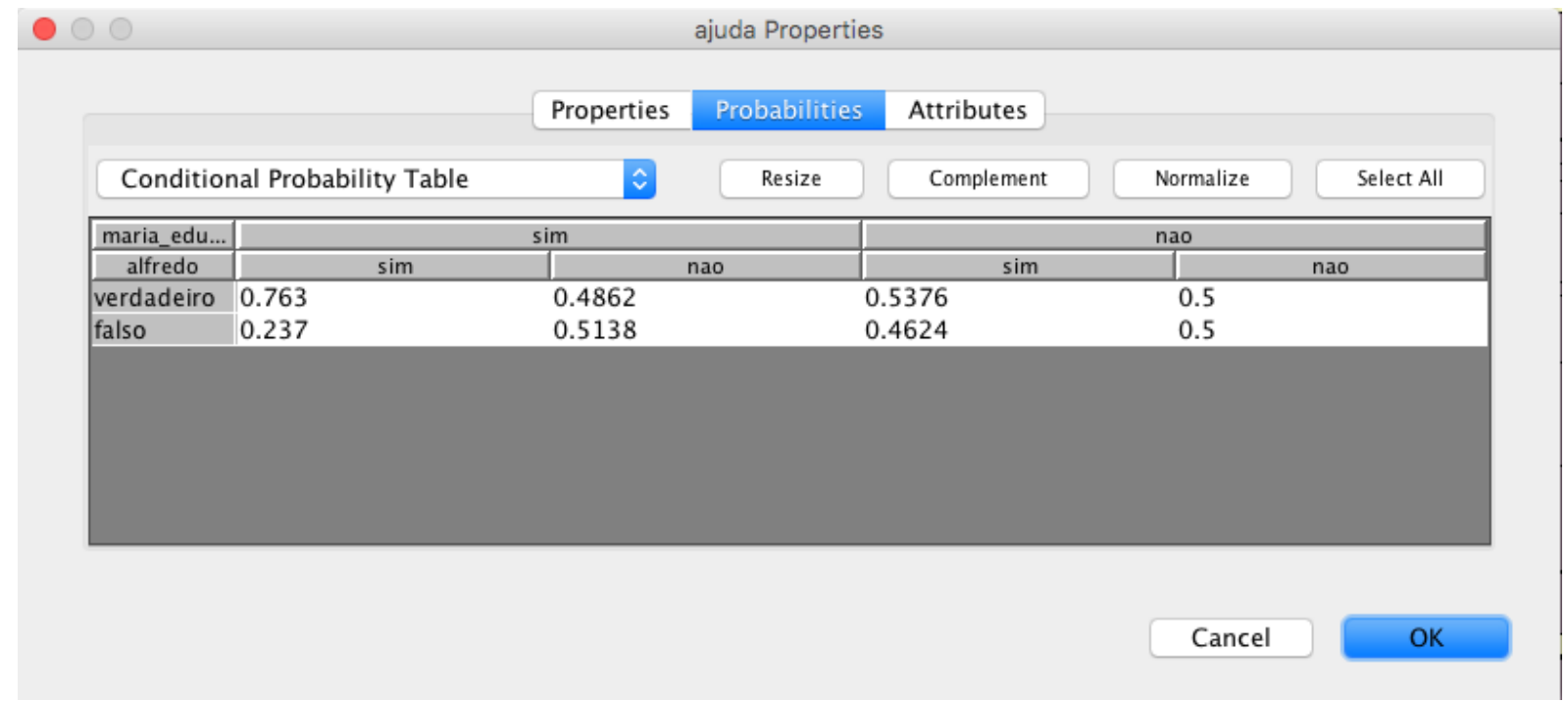

Fonte: Autor. 
Figura 31 - TPC - face

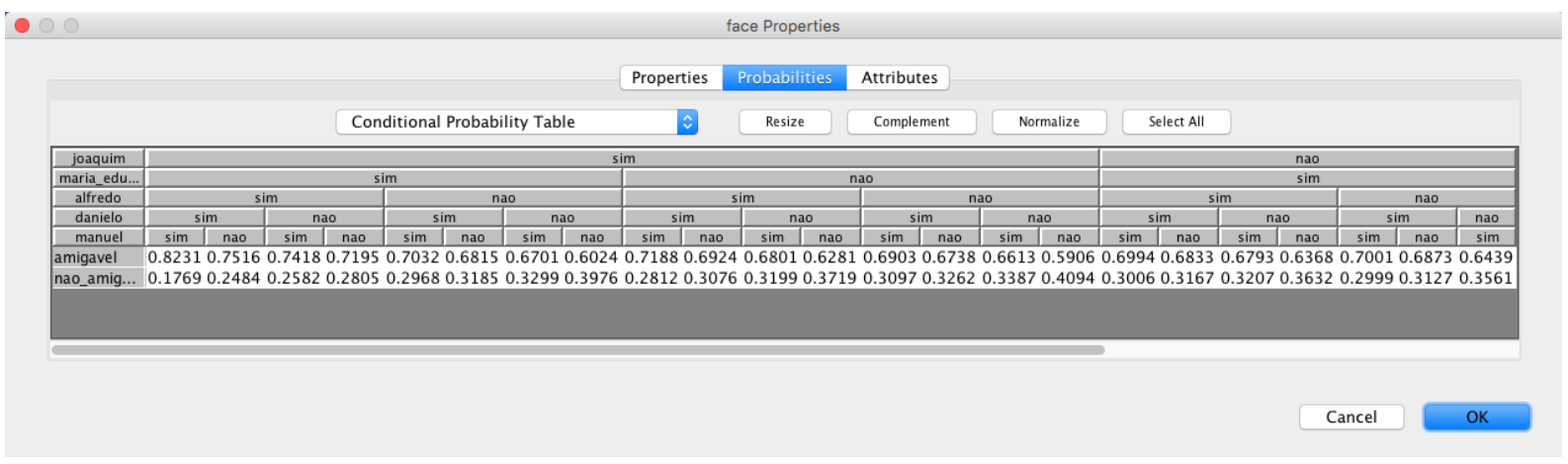

Fonte: Autor.

Figura 32 - TPC - face

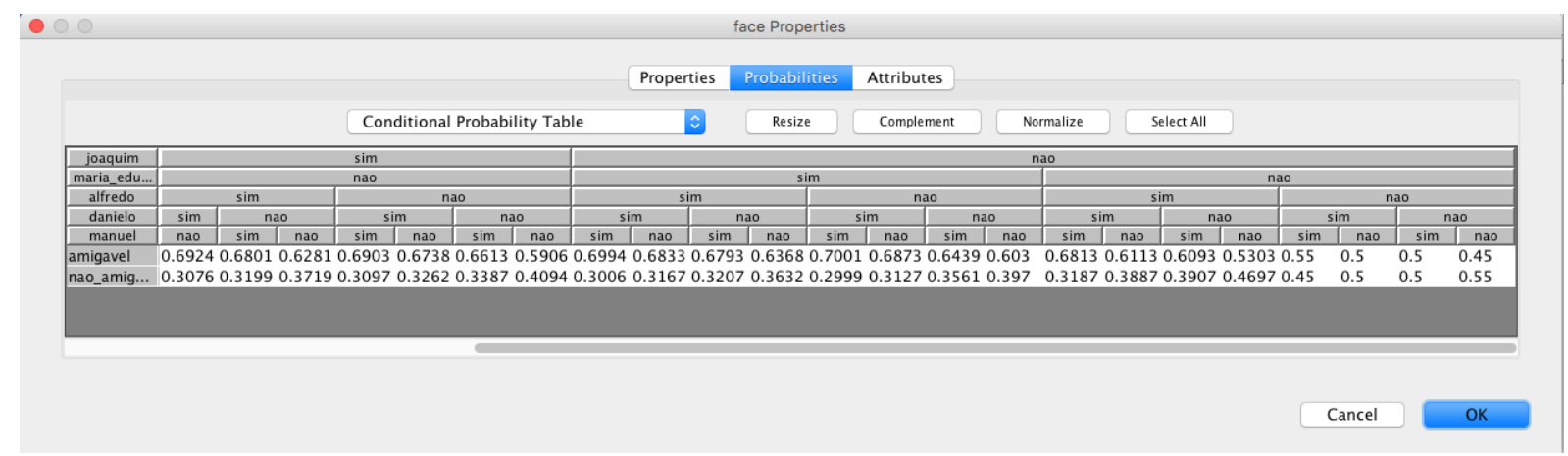

Fonte: Autor.

Figura 33 - TPC - fala

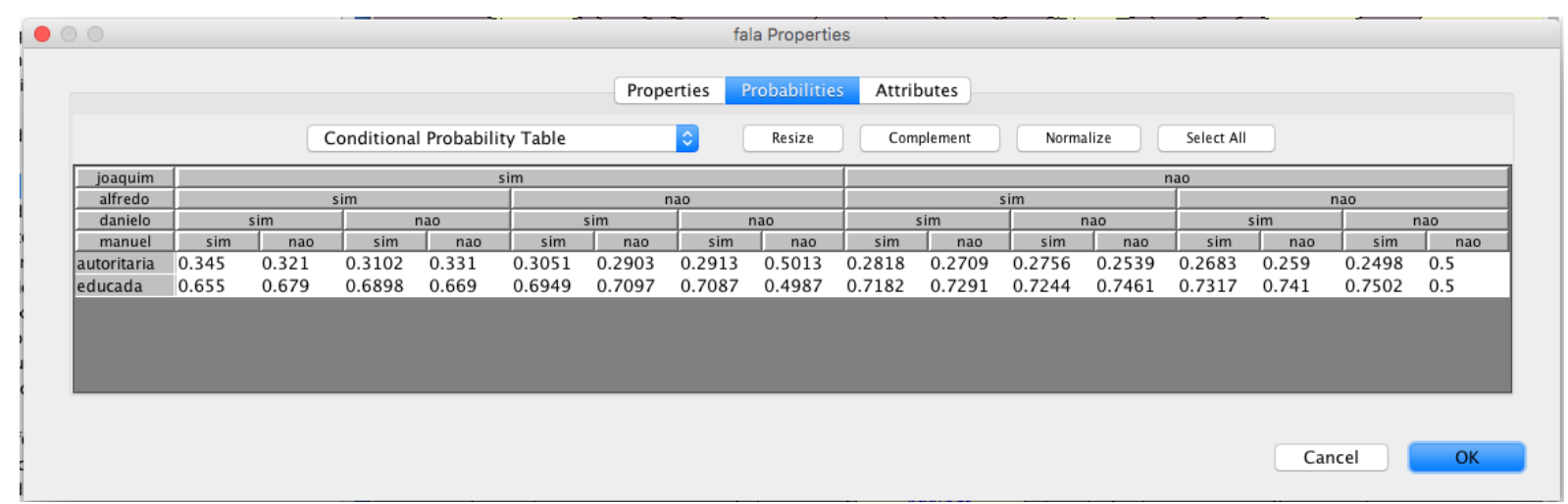

Fonte: Autor. 
Figura 34 - TPC - feedback

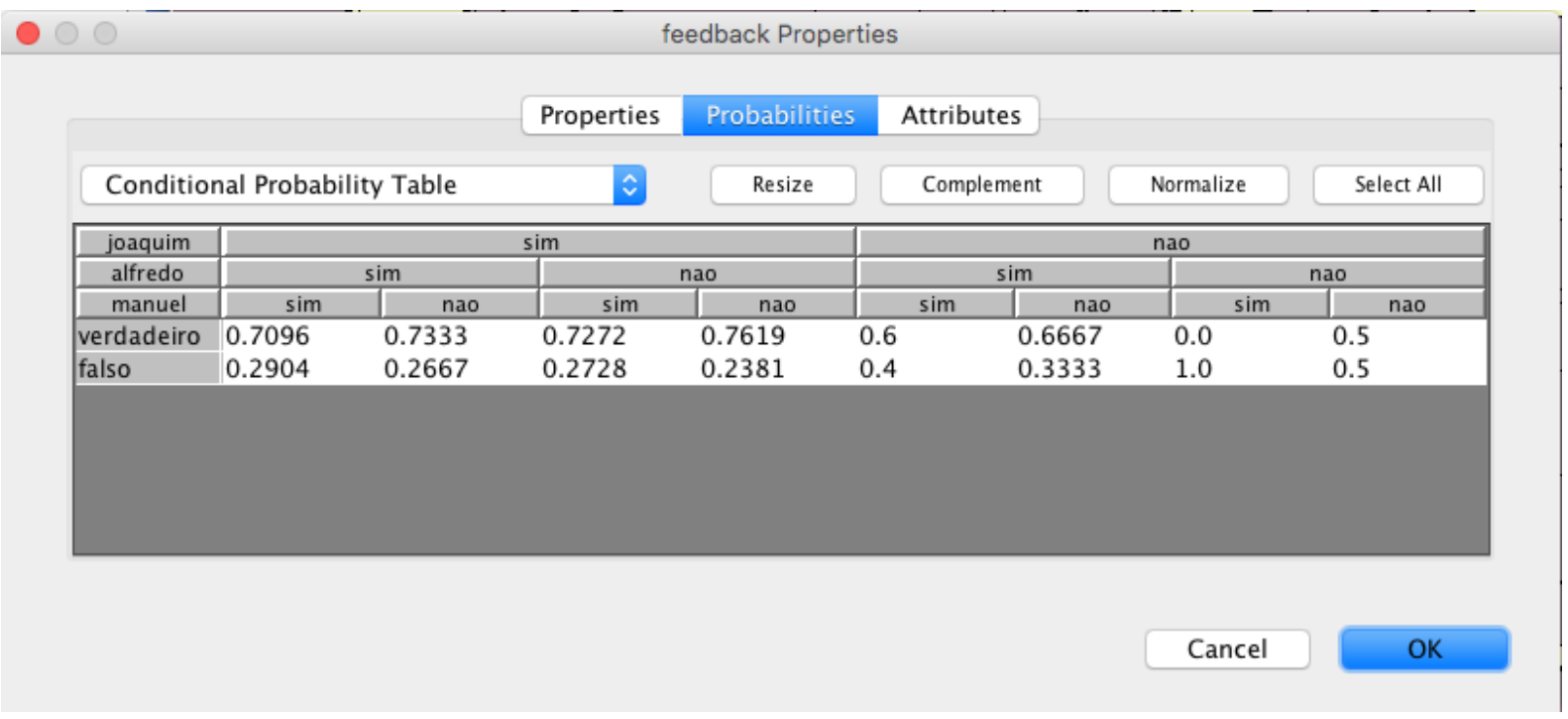

Fonte: Autor.

Figura 35 - TPC - gestos

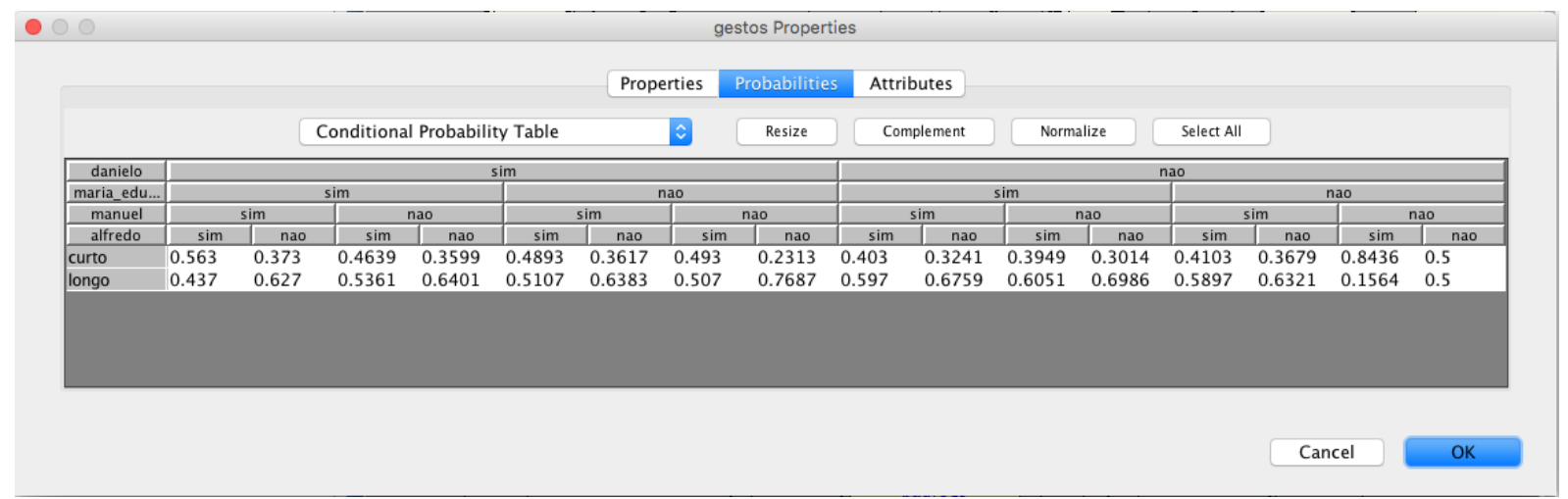

Fonte: Autor. 
Figura 36 - TPC - padroes

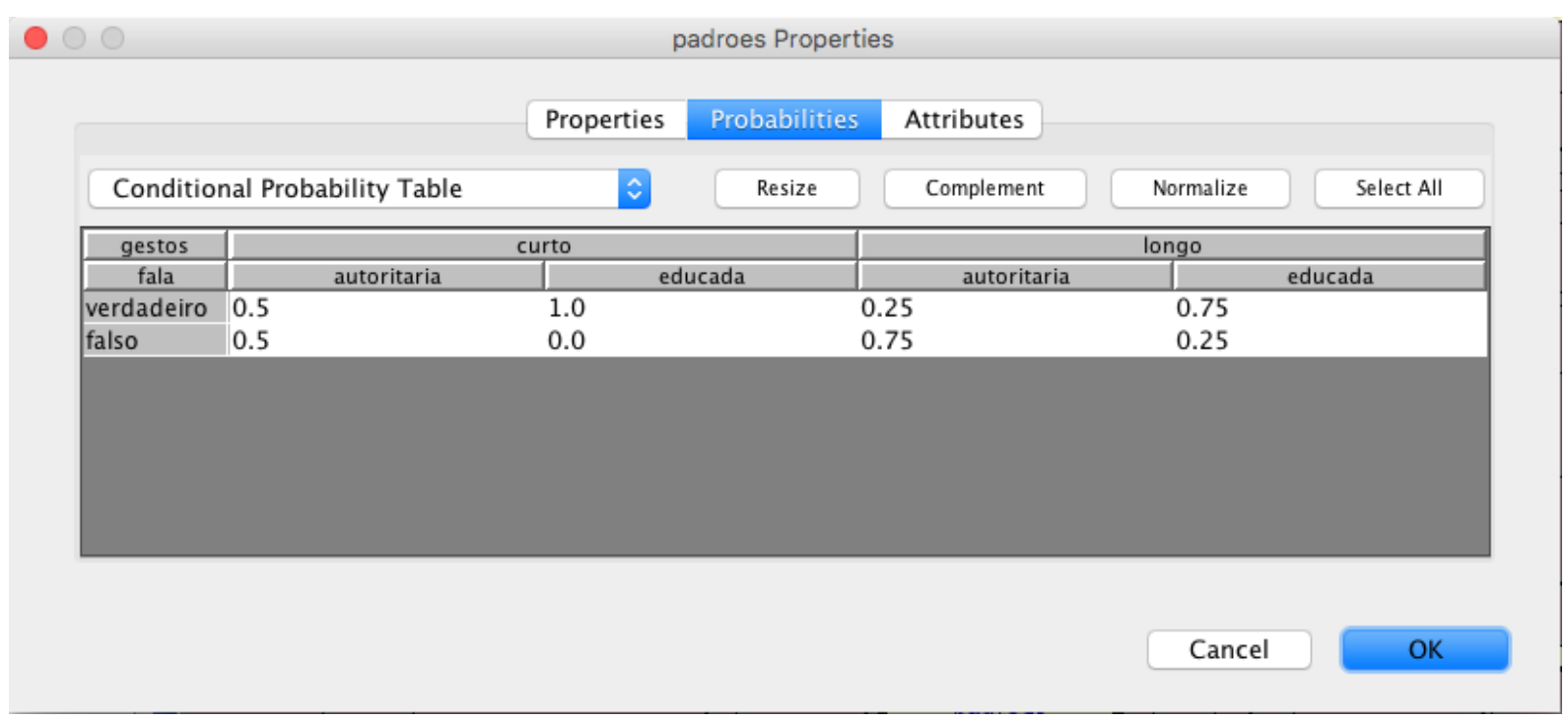

Fonte: Autor.

\section{Figura 37 - TPC - posicao}

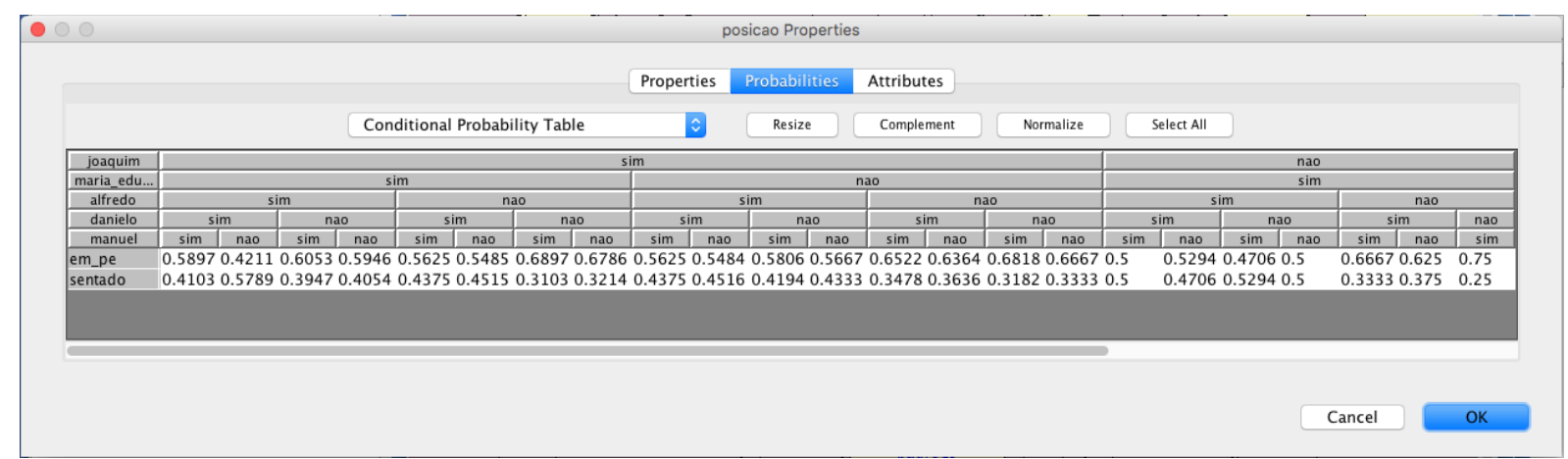

Fonte: Autor.

\section{Figura 38 - TPC - posicao}

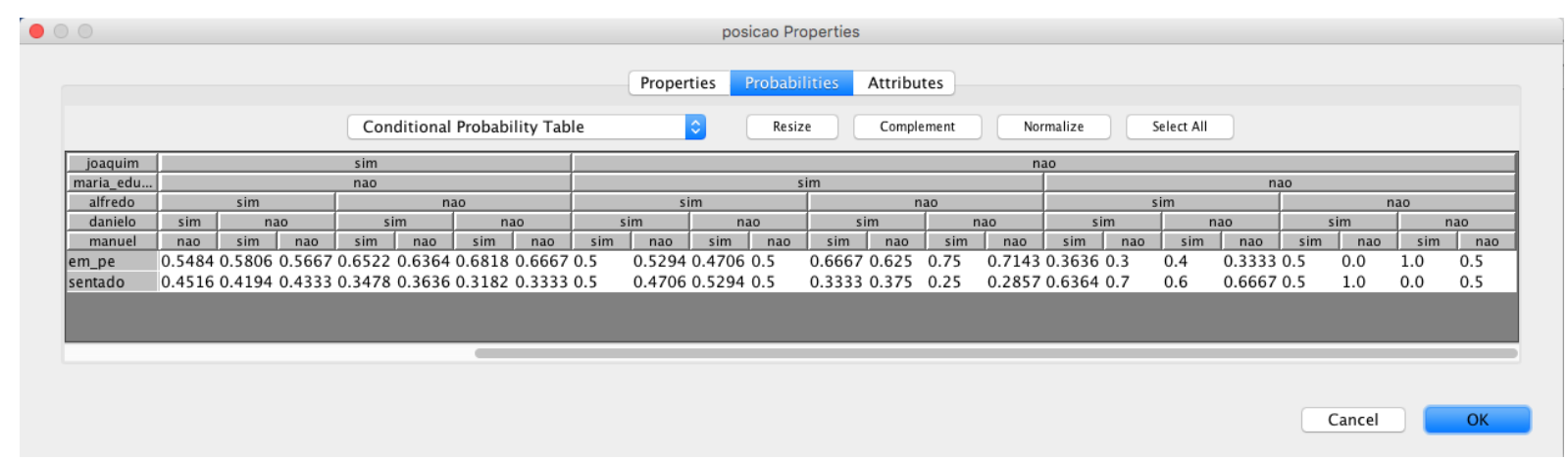

Fonte: Autor. 
Figura 39 - TPC - proximidade

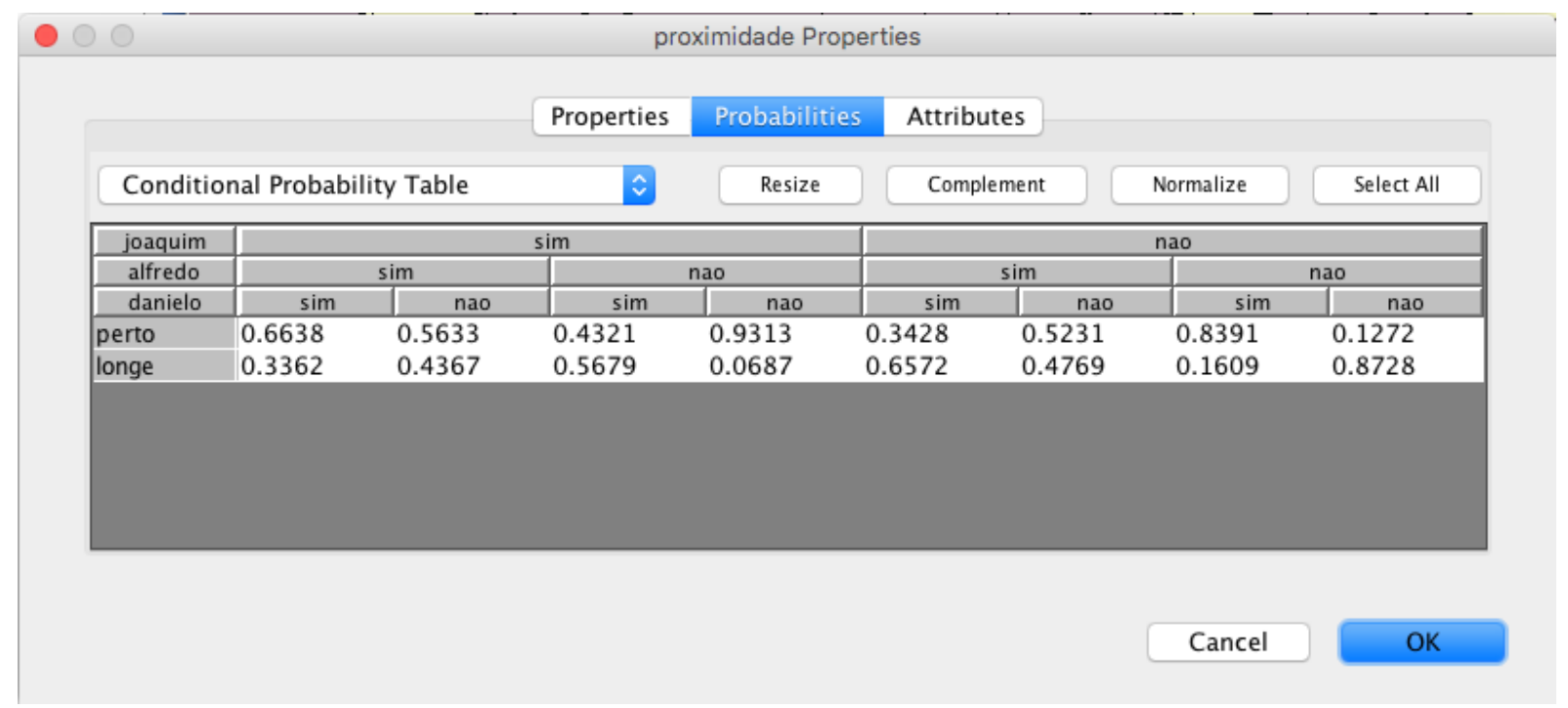

Fonte: Autor.

Figura 40 - TPC - reconhecer

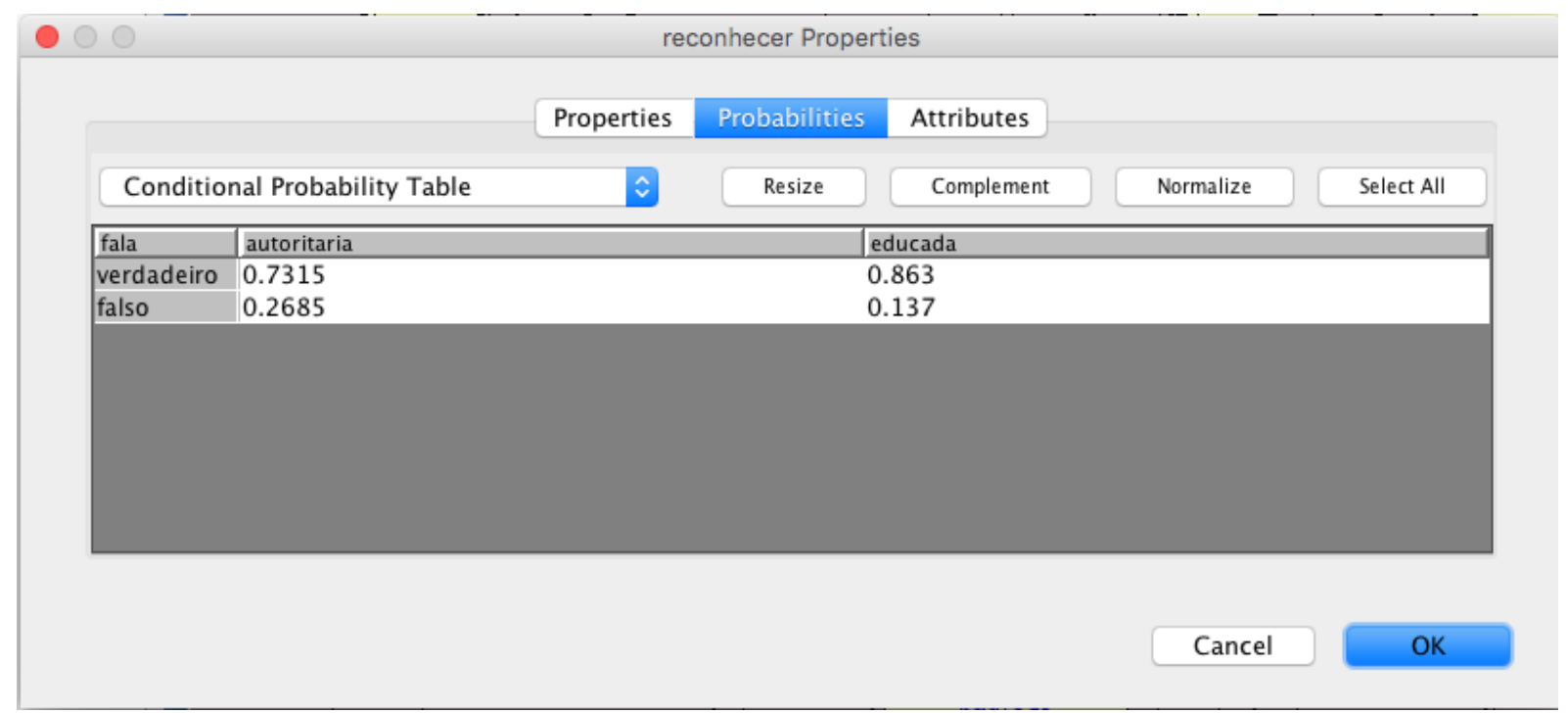

Fonte: Autor. 
Figura 41 - TPC - toque

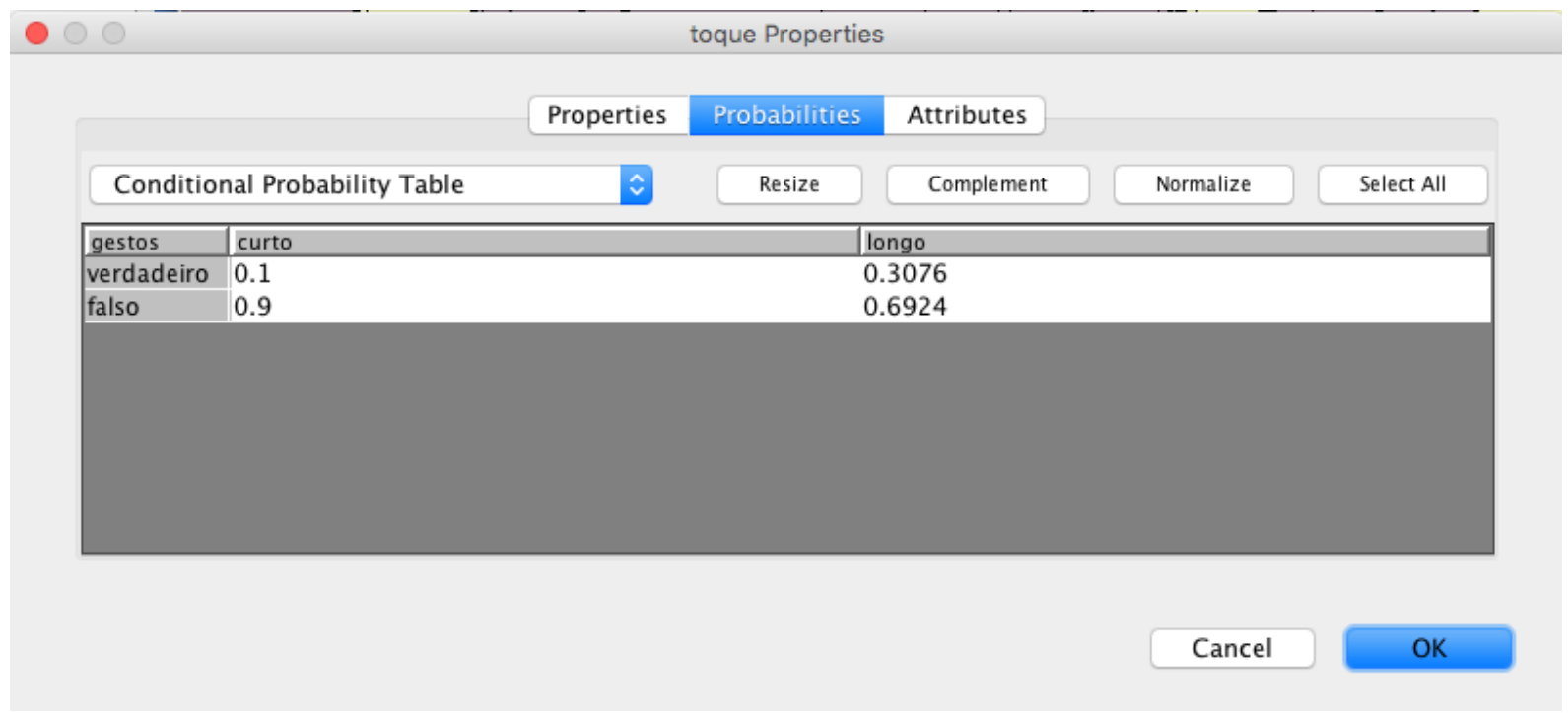

Fonte: Autor

Figura 42 - TPC - velocidade

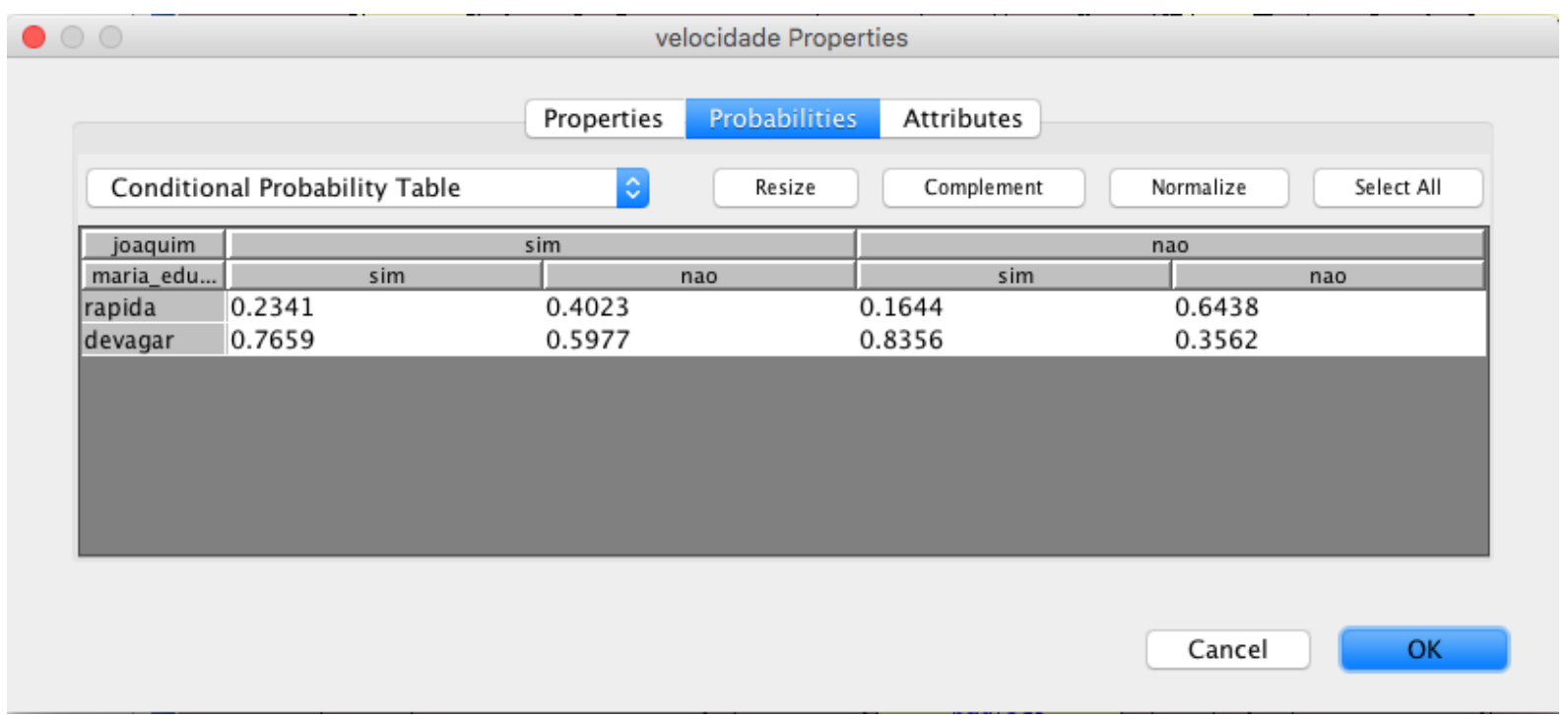

Fonte: Autor 
Figura 43 - TPC - conforto

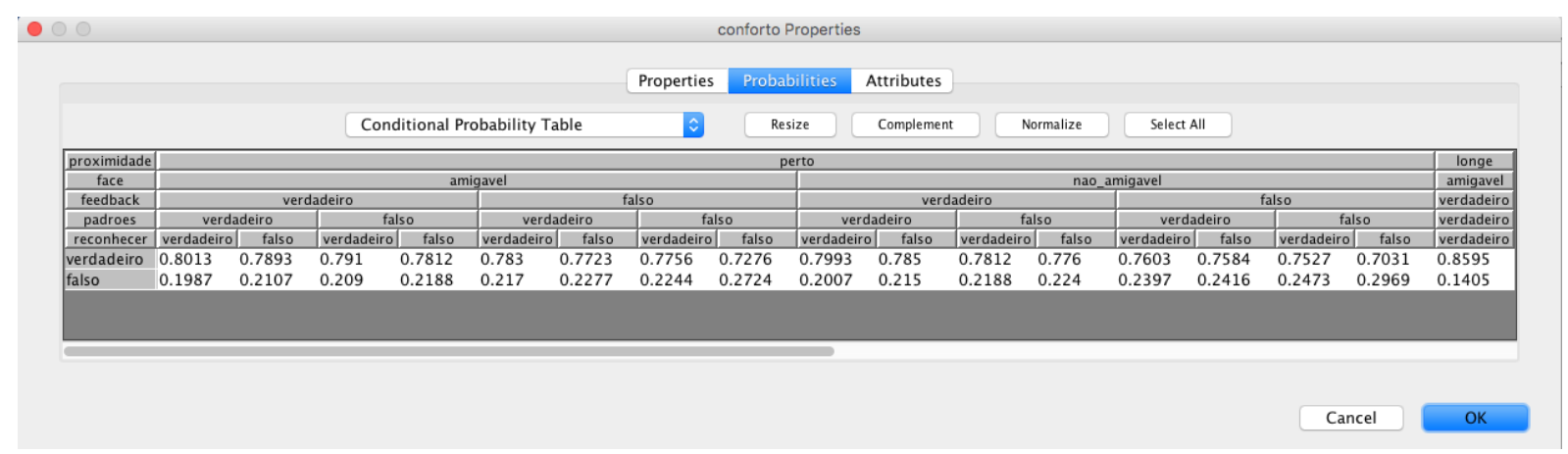

Fonte: Autor.

Figura 44 - TPC - conforto

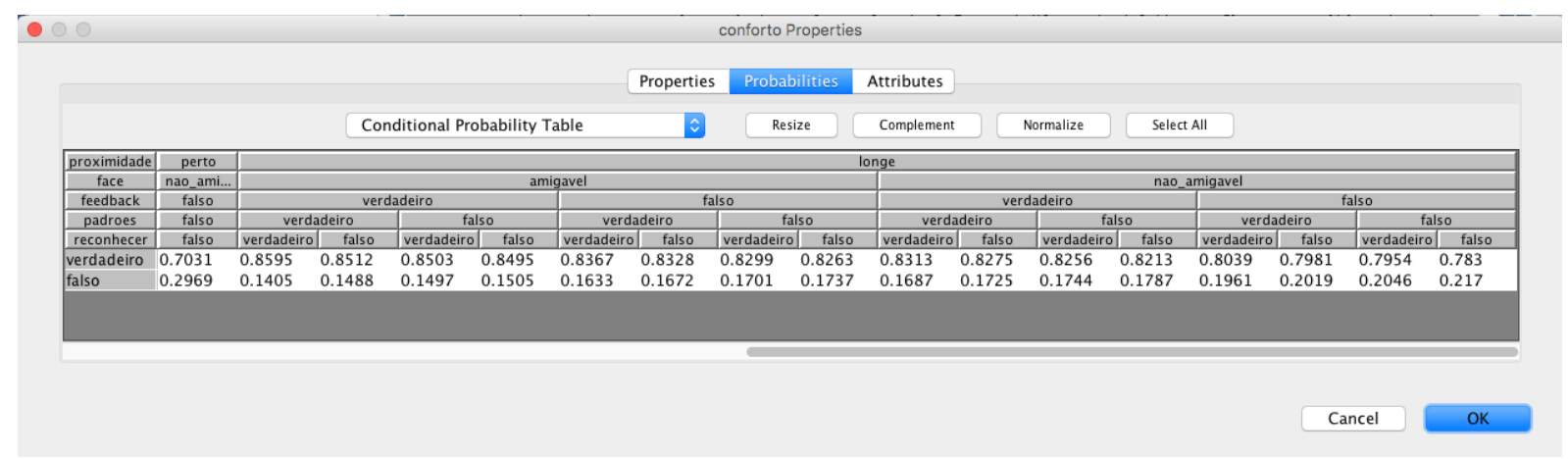

Fonte: Autor.

Figura 45 - TPC - desconforto

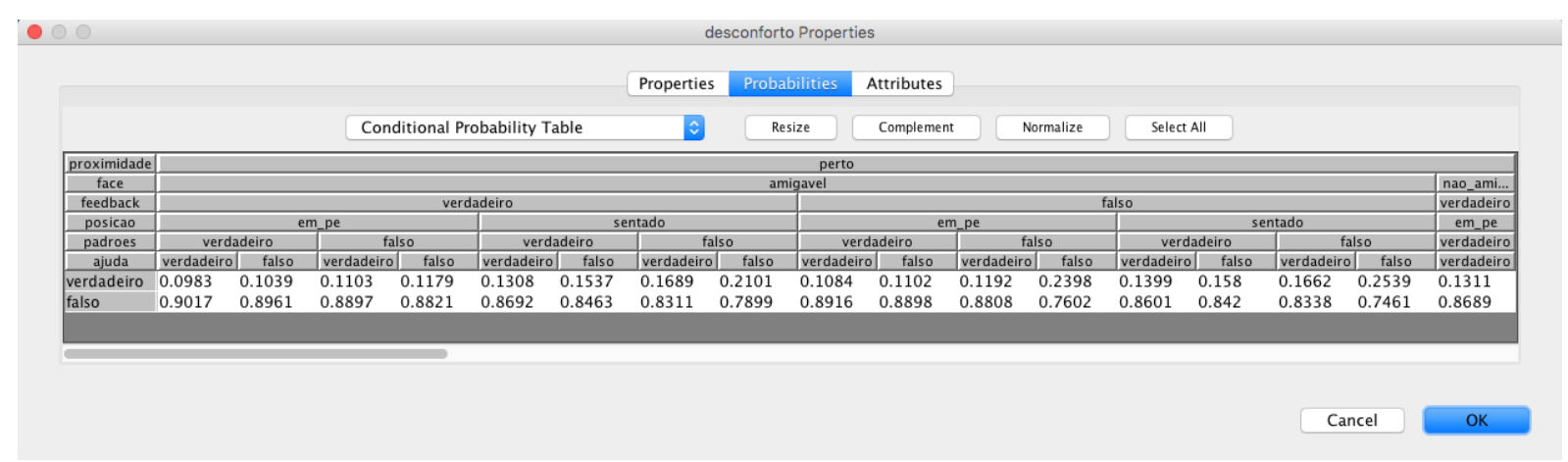

Fonte: Autor. 
Figura 46 - TPC - desconforto

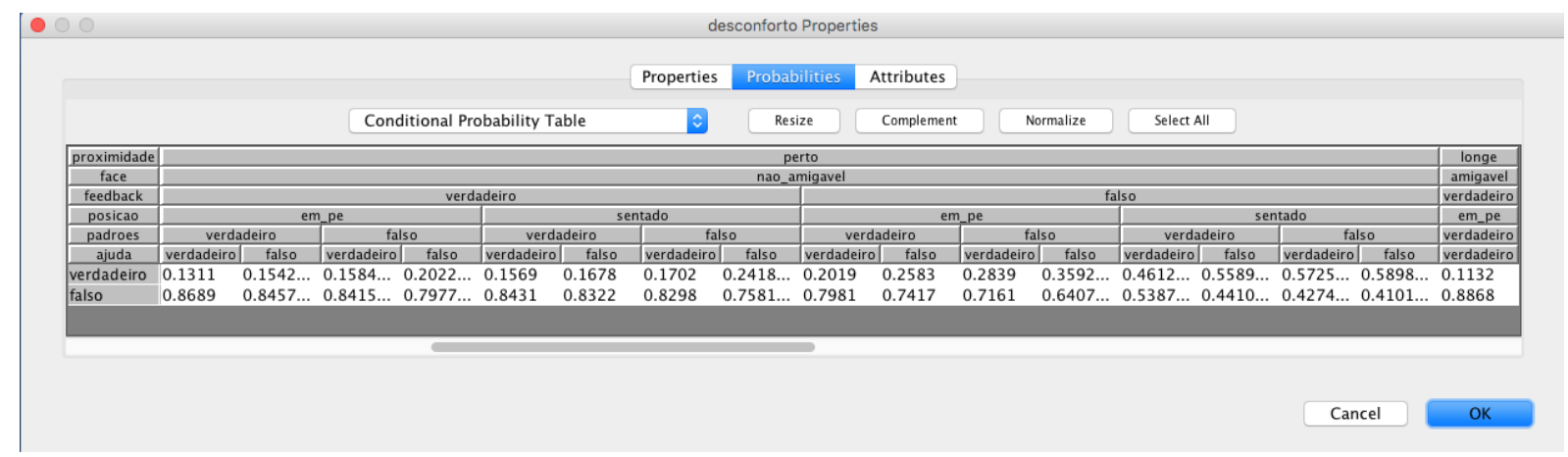

Fonte: Autor.

Figura 47 - TPC - desconforto

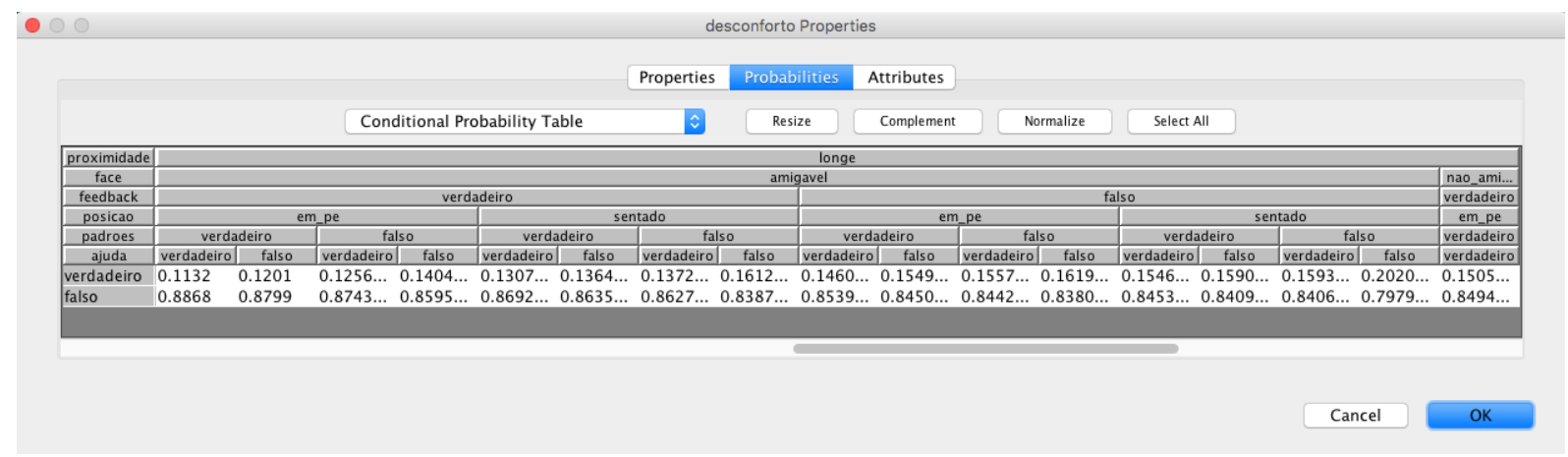

Fonte: Autor.

Figura 48 - TPC - desconforto

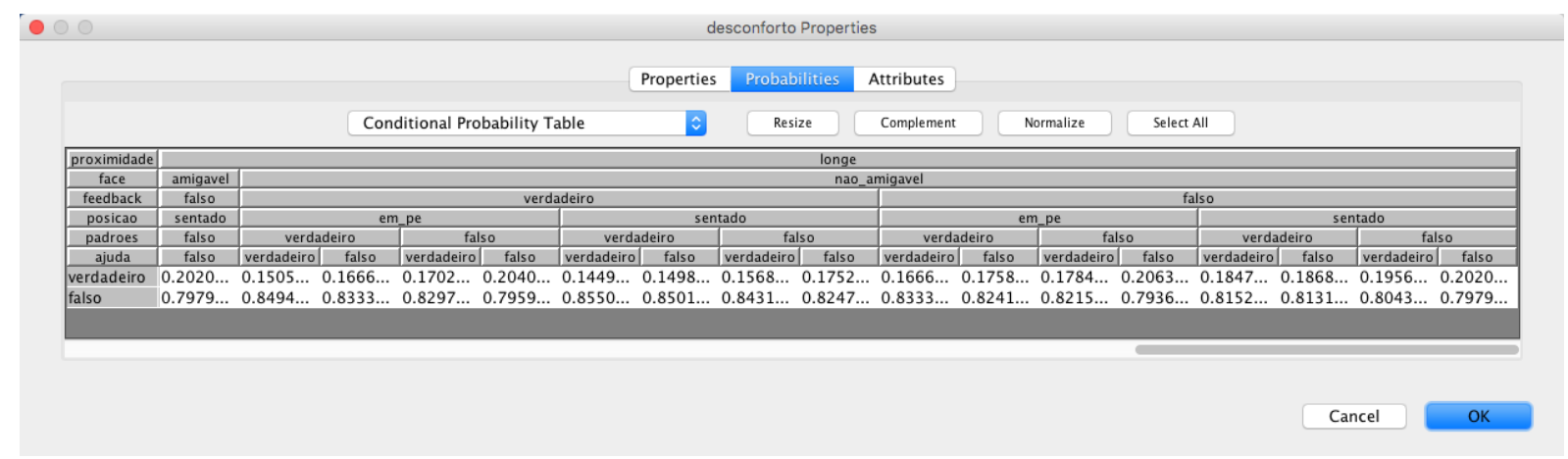

Fonte: Autor. 
Figura 49 - TPC - medo

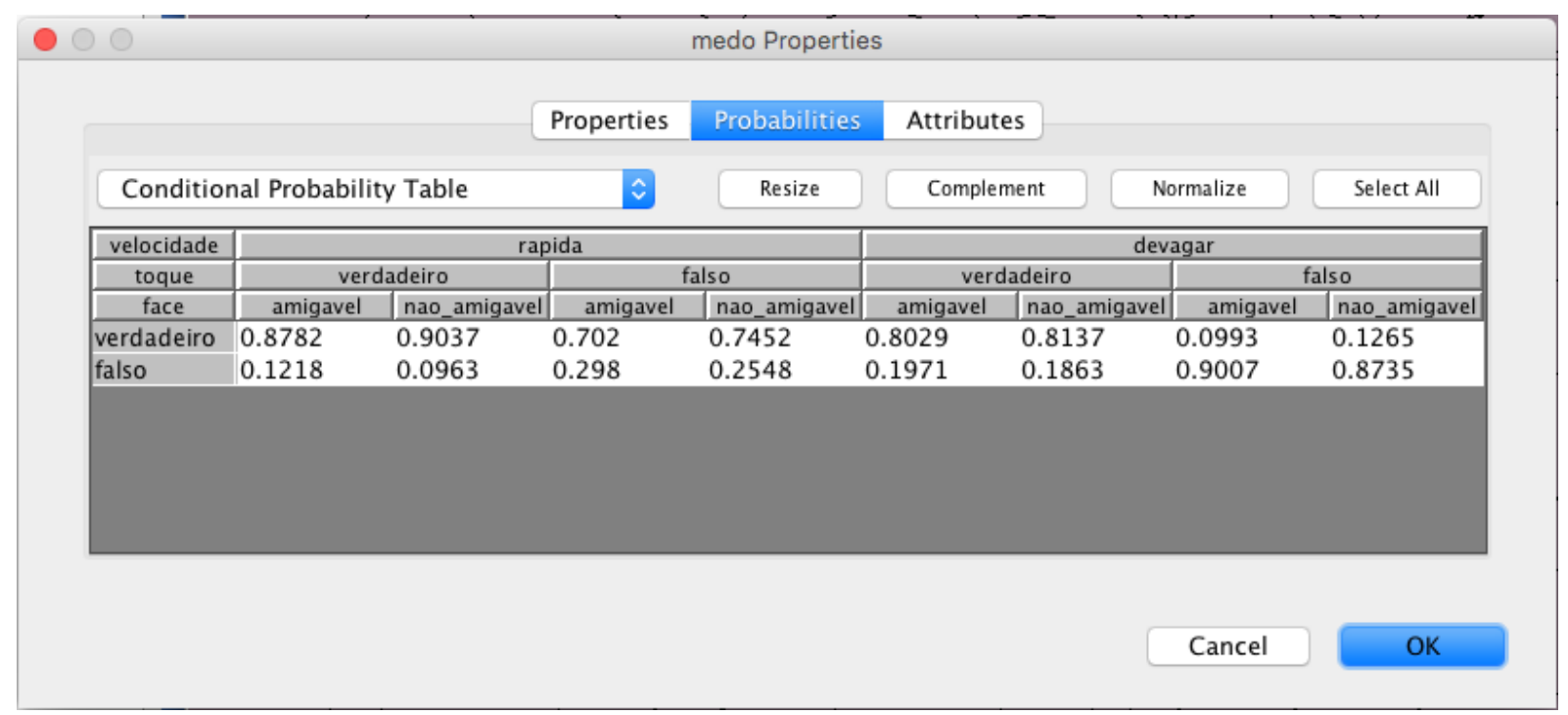

Fonte: Autor. 